



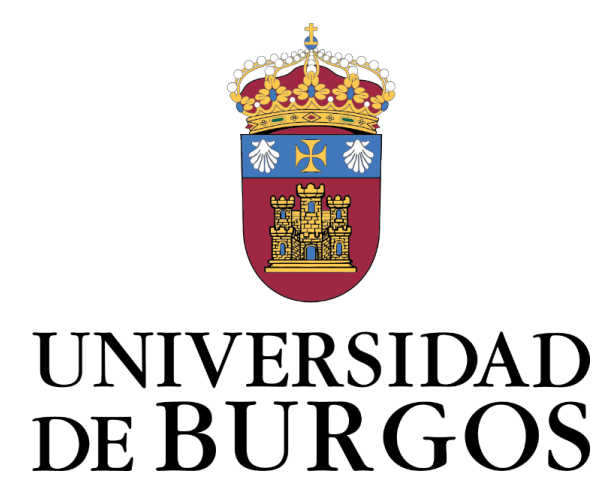

FACULTAD DE EDUCACIÓN

DEPARTAMENTO DE DIDÁCTICAS ESPECÍFICAS

ÁREA DE DIDÁCTICA DE LAS CIENCIAS EXPERIMENTALES

Programa de Doctorado en Educación por la Universidad de Burgos

TESIS DOCTORAL

\section{El desarrollo competencial en la Educación Primaria: efectos de una propuesta STEAM integrada}

Jairo Ortiz Revilla

Directora: Dra. Ileana M. Greca Dufranc Codirector: Dr. Jesús Ángel Meneses Villagrá 

We are not students of some subject matter but students of problems. And problems may cut right across the border of any subject matter or discipline.

Karl Raimund Popper (1963) 

A Raquel y Jara 



\section{AGRADECIMIENTOS}

«¿Cuándo acabas la tesis?» Comienzo este apartado recordando la pregunta que indudablemente más he escuchado desde hace un tiempo y cuyo peculiar desasosiego quizás solo comprendan aquellos que hayan transitado por un largo y trabajoso camino como es la elaboración de una tesis doctoral. Sin embargo, por fin puedo responder a este interrogante evitando dar más largas, pues hoy, 19 de noviembre de 2019 doy por concluida la tesis doctoral que comencé hace algo más de tres años en el despacho 385 de la Facultad de Educación de la Universidad de Burgos.

Durante este periodo, son muchas las personas que han estado a mi lado y sin cuyo apoyo no hubiera sido posible completar esta investigación.

En primer lugar, quiero expresar un especial agradecimiento a mi directora, la Dra. Ileana M. Greca, por despertar en mí el entusiasmo por la Didáctica de las Ciencias Experimentales, por confiar en mí, por dedicarme tanto de tu tiempo y por tus esenciales contribuciones a esta investigación. Sabes que esta tesis lleva tu esencia, gracias Ileana. También quiero dar gracias a mi codirector, el Dr. Jesús Ángel Meneses Villagrá, por estar siempre dispuesto a ayudarme, por aconsejarme desde tu experiencia y por enriquecer esta tesis con tus conocimientos.

Gracias al Dr. Agustín Adúriz-Bravo, por recibirme tan cálidamente en Argentina, por ilustrarme con tu conocimiento y por realizar aportaciones irremplazables a esta tesis.

Al equipo directivo, a los maestros y a todo el alumnado participante del Colegio Público Fernando de Rojas, centro en el que cursé mis estudios de Educación Infantil y Primaria y que me permitió volver a revivir muchos sentimientos.

A ti, Raquel, pareja, amiga y compañera de viaje, por compartir tu vida conmigo, por rescatarme en mi juventud, por soportarme y ayudarme en los momentos más difíciles, por transmitirme tu fuerza y tu manera de ver el mundo, por inculcarme la empatía con el mundo del arte y por haberme dado a la persona que más quiero en el mundo, nuestra hija Jara. 
A mis padres, Fernando y Julia, por criarme y educarme dentro de un mundo de valores, por vuestro apoyo incondicional y por estar siempre dispuestos a escucharme. A mi hermano Sergio, aunque solo aceptabas jugar a la play conmigo cuando era pequeño, siempre has estado a mi lado y me has abierto los ojos cuando más lo he necesitado.

A mi abuela Luci, por ayudarme a sobrevivir durante este tiempo. A mi abuelo Teófilo, mi tío Rafa, mi tía Maripaz, mis sobrinas y resto de mi familia y amigos, por ser parte de lo que soy.

A los que ya no estáis aquí, os llevo dentro y me acuerdo mucho de vosotros. 
Desde la incorporación de las competencias como elemento curricular en la educación a nivel internacional, su complejidad teórica ha suscitado algunos interrogantes que deben ser atendidos. Esta tesis doctoral comienza por la realización de una revisión sistemática y crítica sobre la investigación acerca de este constructo en la etapa de Educación Primaria. Después de elucidar su conceptualización y analizar sus diferentes implicaciones educativas, se revela su carácter pluridimensional y la necesidad de adoptar nuevos enfoques metodológicos para tratar de que todo el alumnado, independientemente de sus gustos o destrezas, sea capaz de alcanzar las competencias indispensables para desenvolverse el mundo actual. Dentro de las posibilidades existentes en el campo de la Didáctica de las Ciencias, se escoge la emergente educación STEAM integrada. STEAM — Science, Technology, Engineering, Arts y Mathematics - y su predecesor STEM integran, a través de la resolución de problemas genuinos y mediante metodologías activas, contenidos de las diversas disciplinas, presentándose apropiados para responder, tanto a la pluridimensionalidad competencial como a la desafiante realidad científicotecnológica. Así, se construye un encuadre teórico con coherencia epistemológica, psicológica y didáctica para la educación STEAM integrada, encuadre que fundamenta el diseño y la implementación de una unidad didáctica enfocada al desarrollo competencial. Empleando la investigación de diseño, se evaluó el desarrollo competencial y las actitudes hacia la ciencia a seis grupos de sexto curso $(\mathrm{N}=121)$ de Educación Primaria en España. Los resultados obtenidos permiten afirmar que esta propuesta, refinada en sucesivas iteraciones, ha producido un desarrollo competencial alto y notablemente más elevado que el derivado de la metodología tradicional, tanto 
en la competencia general del alumnado como en las siete competencias clave propuestas en el currículo oficial. También se han obtenido mejores actitudes hacia la ciencia en comparación con los resultados reportados en la literatura. Todo ello, evidencia que la educación STEM/STEAM integrada, en este caso materializada a través de la indagación y del diseño de ingeniería, representa una posible vía de mejora del desarrollo competencial, en toda su complejidad, del alumnado de Educación Primaria. Por ello, consideramos este enfoque una alternativa potente para contribuir a subsanar las carencias de desarrollo competencial que hoy en día sigue perpetuando la educación tradicional tanto en España como en muchos otros lugares.

Palabras clave: competencia, educación basada en competencias, actitudes hacia la ciencia, educación STEM/STEAM integrada, filosofía de la ciencia, naturaleza de STEM, evaluación, Educación Primaria. 


\section{ABSTRACT}

Since competencies were brought into the international educational systems as a curriculum element, their theoretical complexity has raised some questions that must be addressed. This doctoral thesis begins with a systematic and critical review of the published research on this construct for Primary Education. After elucidating its conceptualization and analyzing its different educational implications, the review revealed the multidimensional character of competencies and the need to adopt new methodological approaches to ensure that all students, regardless of their preferences or skills, are capable of achieving the indispensable competencies for life in the contemporary world. The emerging integrated STEAM education is chosen within the existing possibilities in the field of Didactics of Science. STEAM - Science, Technology, Engineering, Arts and Mathematics — and its predecessor STEM are supposed to integrate, through the resolution of genuine problems and by means of active methodologies, the content of the different disciplines, resulting appropriate to respond to both the competence multidimensionality and the challenging scientific and technological reality. Thus, a coherent epistemological, psychological and didactical framework is constructed for integrated STEAM education, a framework that underpins the design and implementation of a didactical unit focused on competence development. Using Design-Based Research, competence development and attitudes towards science were evaluated in six groups in the sixth grade of Elementary School $(\mathrm{N}=121)$ in Spain. The results obtained allow us to state that this proposal, refined in successive iterations, has produced a notably higher competence development than the one derived from traditional methodologies, both in students' general competence and in the seven key competencies proposed in 
the official curriculum. Better attitudes towards science have also been obtained in comparison with the results reported in the literature. All of this seems to show that integrated STEM/STEAM education, in this case materialized through inquiry and engineering design methodologies, represents a possible way to improve the competence development, in all its complexity, of Primary Education students. For this reason, we consider this approach to be a powerful alternative in order to contribute to filling the gaps in competence development that are still perpetuated in traditional education today in Spain, as in many other countries around the world.

Keywords: competence, competency-based education, attitudes toward science, integrated STEM/STEAM education, philosophy of science, nature of STEM, assessment, primary education. 


\section{ÍNDICE}

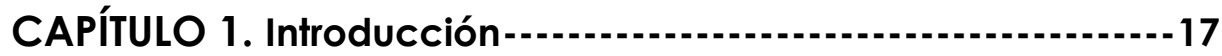

1.1. Antecedentes personales y origen de la investigación ............................. 19

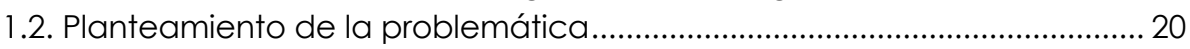

1.3. Establecimiento de las preguntas y de los objetivos de investigación...... 27

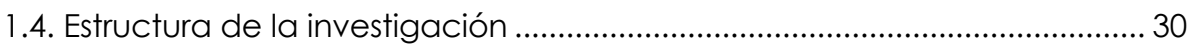

PRIMERA PARTE. Fundamentación teórica

CAPÍTULO 2. Conceptualización de las competencias: revisión sistemática de su investigación en Educación Primaria ---35

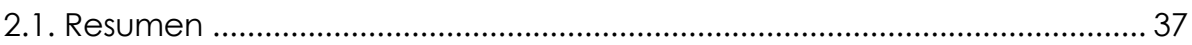

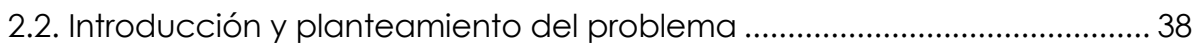

2.3. Encuadre teórico del término competencia ................................................... 39

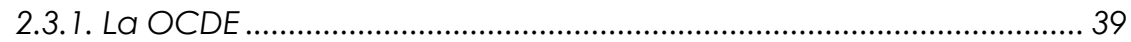

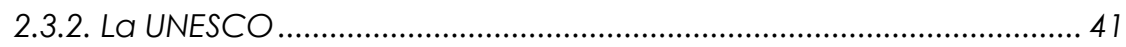

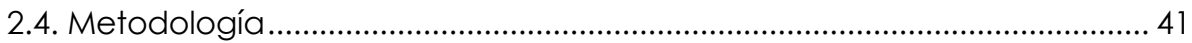

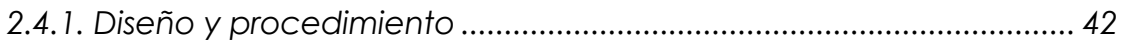

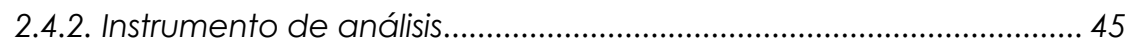

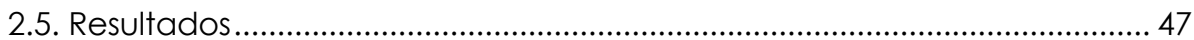

2.5.1. Panorama amplio de los estudios dedicados al constructo competencial en Educación Primaria....................................................... 47

2.5.2. Descripción general de los estudios finales ........................................ 49

2.5.3. Resultados de la revisión en profundidad........................................... 53

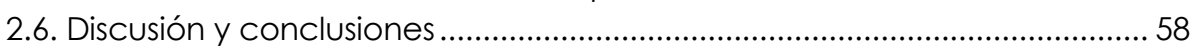

CAPÍTULO 3. Un encuadre teórico para la educación STEM/STEAM integrada-- 63

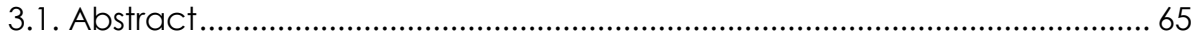

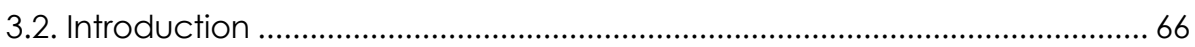

3.3. Some crucial issues about STEM and STEAM education ...............................6 68

3.4. Structure of the theoretical framework ...................................................... 71

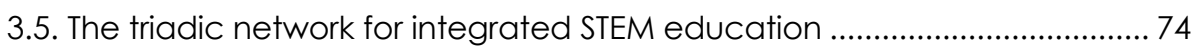

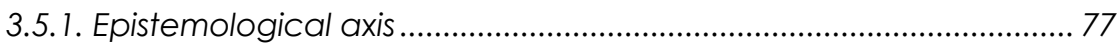

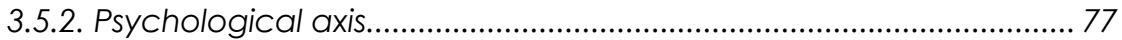

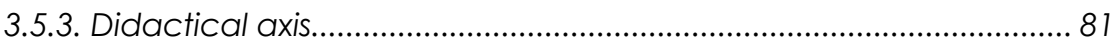

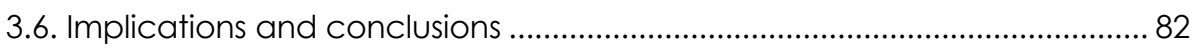

3.7. Supplemental material: applied example of the theoretical framework in

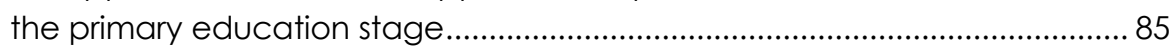




\section{CAPÍTULO 4. Un marco para la discusión epistemológica en torno}

a la educación STEM integrada -

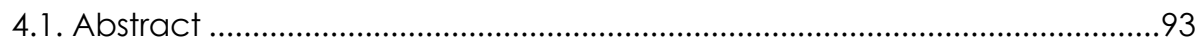

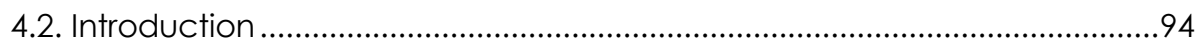

4.3. Revisiting the history of integrated STEM education........................................96

4.4. A humanist perspective for integrated STEM education ................................99

4.5. On the searchfor an epistemological nature of an integrated STEAM

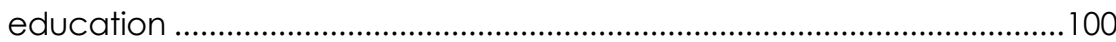

4.6. A model of "seamless web" for understanding the knowledge produced by STEM disciplines

4.7. A possible philosophical framework for integrated STEM education: the "family resemblance approach" ................................................................... 107

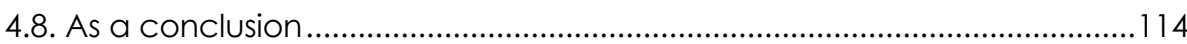

\section{SEGUNDA PARTE. Diseño e implementación de la unidad didáctica__ 117}

CAPÍTULO 5. Propuesta de la unidad didáctica STEAM integrada: la iluminación de mi sala de estudio -

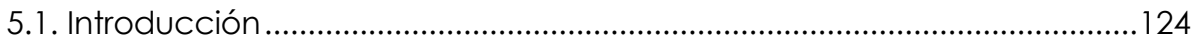

5.2. Contenidos abordados a través del planteamiento STEAM ......................125

5.3. Objetivos de la propuesta didáctica.......................................................129

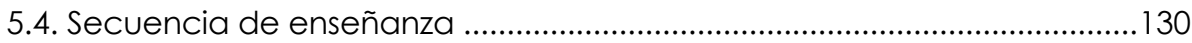

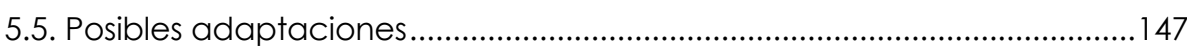

\section{TERCERA PARTE. Metodología, análisis y resultados}

CAPÍTULO 6. Metodología de investigación -..................-151

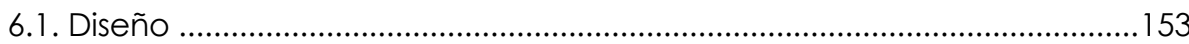

6.1.1. Investigación de métodos mixtos ...................................................153

6.1.2. Investigación de diseño .................................................................. 154

6.2. Recolección de datos .............................................................................156

6.2.1. Descripción detallada de los instrumentos de recolección de datos

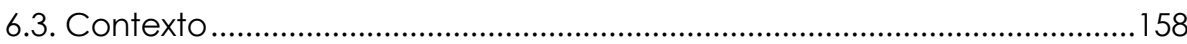

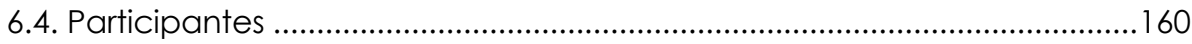

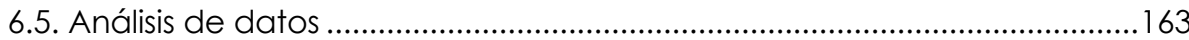

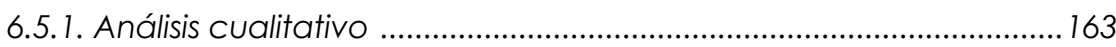

6.5.1.1. Interpretación de las notas de campo ............................. 163 
6.5.1.2. Rúbrica de evaluación de las actividades de la UD y escala de observación de EAE .................................................................... 163

6.5.1.3. Instrumento de evaluación del desarrollo competencial

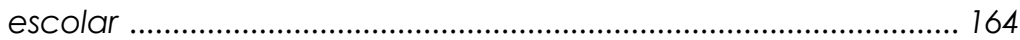

6.5.2. Análisis cuantitativo........................................................................... 167

6.5.2.1. Tratamiento del conjunto de datos numéricos procedente del análisis cualitativo 168

6.5.2.2. Análisis del instrumentode evaluación de actitudes hacia la ciencia e intenciones hacia la ciencia, la ingeniería y su conjunto

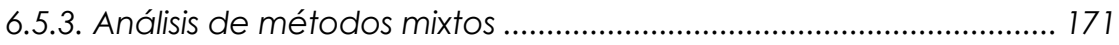

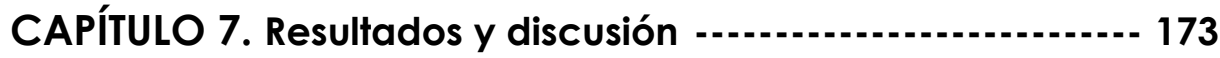

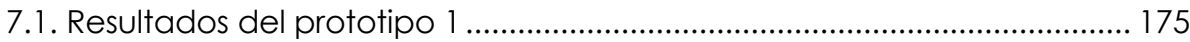

7.1.1. Resultados del análisis cualitativo .................................................. 175

7.1.1.1. Resultados de la interpretación de las notas de campo 175

7.1.1.2. Resultados de la evaluación competencial escolar ...... 177

7.1.2. Resultados del análisis cuantitativo ................................................... 178

7.1.2. 1.Resultados del tratamiento del conjunto de datos numéricos procedente del análisis cualitativo ............................................. 178

7.1.2.2. Resultados de la evaluación de actitudes hacia la ciencia e intenciones hacia la ciencia, la ingeniería y su conjunto ........... 179

7.1.3. Mejoras para el Prototipo 2 de la UD derivadas de los resultados obtenidos .............................................................................................. 179

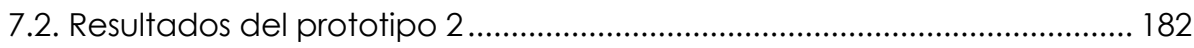

7.2.1. Resultados del análisis cualitativo ................................................... 182

7.2.1.1. Resultados de la interpretación de las notas de campo 182

7.2.1.2. Resultados de la evaluación competencial escolar ...... 183

7.2.2. Resultados del análisis cuantitativo ................................................. 184

7.2.2. 1.Resultados del tratamiento del conjunto de datos numéricos procedente del análisis cualitativo .............................................. 184

7.2.2.2. Resultados de la evaluación de actitudes hacia la ciencia e intenciones hacia la ciencia, la ingeniería y su conjunto ........... 185

7.2.3. Mejoras para el Prototipo 3 de la UD derivadas de los resultados

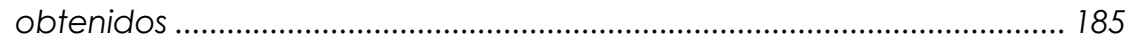

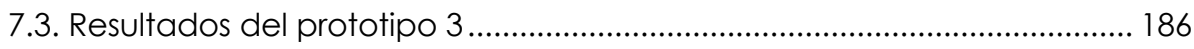

7.3. 1. Resultados del análisis cualitativo .................................................... 186

7.3.1.1. Resultados de la evaluación competencial escolar ...... 186

7.3.2. Resultados del análisis cuantitativo ............................................... 187

7.3.2.1. Resultados del tratamiento del conjunto de datos numéricos procedente del análisis cualitativo ............................ 187 
7.3.2.2. Resultados de la evaluación de actitudes hacia la ciencia

e intenciones hacia la ciencia, la ingeniería y su conjunto........... 188

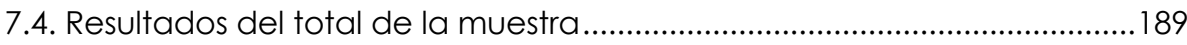

7.4.1. Resultados del análisis cualitativo ................................................... 189

7.4. 1.1. Resultados de la evaluación competencial escolar ....... 189

7.4.2. Resultados del análisis cuantitativo ................................................. 190

7.4.2.1.Resultados del tratamiento del conjunto de datos numéricos procedente del análisis cualitativo ................................................. 190

7.4.2.2. Resultados de la evaluación de actitudes hacia la ciencia e intenciones hacia la ciencia, la ingeniería y su conjunto .............. 199

7.4.2.3.Comparación de los resultados de la evaluación de actitudes hacia la ciencia e intenciones hacia la ciencia, la ingeniería y su conjunto entre quinto y sexto curso

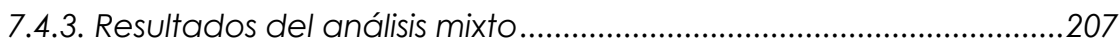

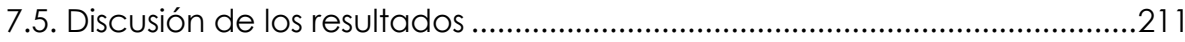

\section{CUARTA PARTE. Conclusiones _ 219}

CAPÍTULO 8. Conclusiones -.............................................. 221

8.1. Respuestas encontradas a las preguntas de investigación planteadas 223

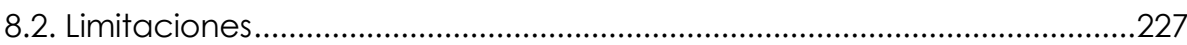

8.3. Futuras líneas de investigación .................................................................228

CAPÍTULO 9. Referencias bibliográficas --_e 231

RELACIÓN DE TABLAS Y FIGURAS POR CAPÍTULOS ___ 277

RELACIÓN DE SIGLAS__ 285

ANEXOS 289 


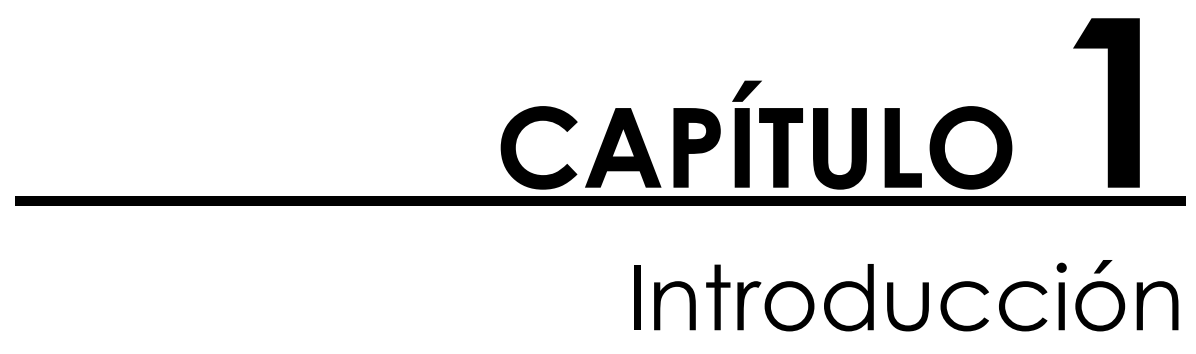





\subsection{Antecedentes personales y origen de la investigación}

La presente tesis doctoral se enmarca dentro del campo de la Didáctica de las Ciencias Experimentales, aunque mi formación multidisciplinaria en distintas ramas vinculadas a la didáctica y a la investigación didáctica en el ámbito de la Educación Primaria también se ha reflejado significativamente en esta investigación.

De esta andadura, lo que posiblemente más me haya impresionado es profundizar en el mundo de las metodologías que pueden ser empleadas en la enseñanza, tan atrayentes como diversas y, a menudo, cambiantes. En este sentido, y quizá porque durante mi infancia y adolescencia no representé la figura de un alumno destacado dentro de lo que ya parece poderse llamar, sin disimulos, la caducada educación tradicional ${ }^{1}$, es especial mi interés en que la educación actual evolucione hacia el denominado aprendizaje activo y las metodologías activas (Michael, 2006; Niemi, 2002; Prince, 2004), una interesante vertiente metodológica con la que, no obstante, también tuve el gusto de encontrarme en algunas ocasiones. Curiosamente son aquellos momentos los que más recuerdo de mi etapa de escolarización obligatoria y seguramente aquellos profesores tuvieron mucho que ver en la gran fascinación que hoy siento por la didáctica.

Tras mi supervivencia a la clase magistral, a las metodologías expositivas y a los libros de texto, comenzó mi vida universitaria, donde fueron múltiples las actividades, secuencias, propuestas, unidades, programaciones didácticas, etc. que desarrollé dentro de un amplio abanico de materias, de contextos y de pretensiones didácticas ampliamente dispares. Durante este tiempo tuve la suerte de conocer a grandes profesionales que siguieron incentivando mis inquietudes relativas al mundo de la educación y, sobre todo, me permitieron conocer que existían otras maneras de enseñar.

Entre tanto, conocí a quien ciertamente me transmitió un interés especial por la Didáctica de las Ciencias Experimentales — la directora de esta tesis doctoral Dra. Ileana M. Greca-. Juntos ya planificamos y presentamos

\footnotetext{
1 Véanse, por ejemplo, algunas importantes referencias relativas a diferentes ámbitos del mundo educativo (Acaso, 2013, 2014; Confederación de Sociedades Científicas de España [COSCE], 2011; National Research Council [NRC], 2014; Organización de las Naciones Unidas para la Educación, la Ciencia y la Cultura [UNESCO], 2015; Osborne y Dillon, 2008; Zabala y Arnau, 2007).
} 
una propuesta de una programación didáctica de la materia de Ciencias de la Naturaleza para el segundo curso de Educación Primaria a través de la metodología de enseñanza de las ciencias basada en la indagación (ECBI) (Ortiz-Revilla, 2016; Ortiz-Revilla y Greca, 2017), una de las metodologías activas por excelencia (Bevins y Price, 2016). Intentando definir un punto de partida de esta investigación creo que este fue su germen más incipiente.

Mi formación, como he comentado, ha bebido de la práctica y de la investigación educativa, percibiéndolas en numerosas ocasiones demasiado distanciadas e incluso confrontadas. Por ello, en la tesis doctoral que a continuación se presenta se ha mantenido de inicio a fin la preocupación por aplicar la investigación educativa a la práctica docente, por la plausibilidad de extrapolar lo investigado al aula real; en definitiva, por reducir la popular brecha entre investigación y práctica educativa, tópico ampliamente abordado en la literatura (Biesta, 2007; Broekkamp y van Hout-Wolters, 2007; Fernández Cano, 2001; Kennedy, 1997; McIntyre, 2005; Vanderlinde y van Braak, 2010).

\subsection{Planteamiento de la problemática}

Como es bien sabido, uno de los asuntos que permanentemente rodea al ámbito de la didáctica y, concretamente, a la labor de programar en el contexto de la educación formal es el famoso currículo, concepto que ha sido objeto de múltiples definiciones y que no cuenta con demasiado acuerdo en la literatura en cuanto a su significado (Angulo Rasco, 1994; Gimeno Sacristán, 2013; Lundgren, 1991). No obstante, este ha sido ampliamente definido como una tentativa para comunicar los principios y los rasgos esenciales de un propósito educativo, permaneciendo abierto a discusión crítica y pudiendo ser trasladado de manera efectiva a la práctica (Stenhouse, 1975).

En España, la toma efectiva de decisiones acerca de las políticas educativas reside en el Gobierno y en las distintas cámaras de representación parlamentaria. Es así como, en este país, numerosas leyes en materia educativa se han ido sucediendo, suprimiendo, modificando o incorporando, a modo de sucesivas reformas y contrarreformas, variedad de asuntos curriculares a menudo teñidos de objetivos políticos lejanos a las reales preocupaciones educativas (Saura y Luengo Navas, 2015). Pero no me extenderé en este sentido. Así, la Ley 14/1970, de 4 de agosto, General de Educación y 
Financiamiento de la Reforma Educativa (LGE, 1970), la Ley Orgánica 1/1990, de 3 de octubre, de Ordenación General del Sistema Educativo (LOGSE, 1990), la Ley Orgánica 10/2002, de 23 de diciembre, de Calidad de la Educación (LOCE, 2002) no llegada a aplicar, la Ley Orgánica 2/2006, de 3 de mayo, de Educación (LOE, 2006) y la Ley Orgánica 8/2013, de 9 de diciembre, para la mejora de la calidad educativa (LOMCE, 2013) representan las leyes en materia educativa que han afectado de una $u$ otra manera al currículo en España desde el periodo preconstitucional, allá por la década de 1970.

Entre otros puntos de inflexión destacables derivados de la legislación educativa, ya se contempló con la LGE la modernización de un sistema educativo nacido en tiempos de la dictadura o se presenció la macroreforma estructural de la LOGSE (de Puelles Benítez, 2000). Más recientemente y en un adentramiento al cuerpo de estudio de esta investigación, surgió con la LOE (2006) la inclusión de las competencias básicas como un elemento más del currículo - junto con el conjunto de objetivos, contenidos métodos pedagógicos y criterios de evaluación de cada una de las enseñanzas reguladas - y se produjo su incorporación por primera vez a las enseñanzas mínimas, una de las novedades más significativas de esta ley. Así, en el Real Decreto 1513/2006, de 7 de diciembre, por el que se establecían las enseñanzas mínimas de la Educación Primaria con la LOE (RD 1513/2006, 2006), se fijaban ocho competencias básicas que el alumnado debía desarrollar a lo largo de la Educación Primaria y alcanzar en la Educación Secundaria Obligatoria (ESO). Por su parte, la LOMCE (2013) introdujo posteriormente una serie de modificaciones en lo determinado en la LOE, una de las cuales, en la designación terminológica de las competencias básicas, pasando a denominarse competencias clave. Actualmente, las competencias clave siguen representando un elemento curricular junto con los objetivos de cada enseñanza y etapa educativa; los contenidos, o conjuntos de conocimientos, habilidades, destrezas y actitudes que contribuyen al logro de los objetivos y a la adquisición de competencias; la metodología didáctica, que comprende tanto la descripción de las prácticas docentes como la organización del trabajo de los docentes; los estándares y resultados de aprendizaje evaluables y los criterios de evaluación del grado de adquisición de las competencias y del logro de los objetivos de cada enseñanza y etapa educativa. En el Artículo 2 del Real Decreto 126/2014, de 28 de febrero, por el que se establece en la actualidad el currículo básico de 
la Educación Primaria (RD 126/2014, 2014), se definen las competencias como «capacidades para activar y aplicar de forma integrada los contenidos propios de cada enseñanza y etapa educativa, para lograr la realización adecuada de actividades y la resolución eficaz de problemas complejos» (p. 19349). En el mismo Artículo 2 se presentan esta vez siete competencias clave definidas por la Unión Europea y consideradas como «aquellas que todas las personas precisan para su realización y desarrollo personal, así como para la ciudadanía activa, la inclusión social y el empleo» (p. 19350).

En un nivel de concreción mayor, las diferentes comunidades autónomas también proporcionan su particular comprensión del currículo a través de las diversas leyes autonómicas y, con ello, se puede seguir encontrando cuantiosa información acerca del término competencia. Por ejemplo, y recogiendo la información concreta del ámbito territorial en el que se ha realizado esta investigación, el Decreto 26/2016, de 21 de julio, por el que se establece actualmente el currículo y se regula la implantación, evaluación y desarrollo de la Educación Primaria en la Comunidad de Castilla y León (Decreto 26/2016, 2016), considera a las competencias clave un elemento del currículo que se debe desarrollar a través de una metodología comunicativa, activa y participativa.

Así, desde la entrada en vigor en España de las dos últimas legislaciones en materia educativa se ha venido haciendo uso del término competencia a la hora de enfocar el proceso de enseñanza-aprendizaje en las dos etapas de escolarización obligatorias, la Educación Primaria y la ESO, entre otras. Esto no quiere decir que anteriores sistemas educativos no se hayan intentado ocupar, en mayor o menor medida, de tales competencias clave, aunque no se haya usado explícitamente este término en España u otros como key skills, core skills, essential skills, life skills, basic skills, key competencies, core competencies o basic competencies en otros lugares.

Parece que las competencias han venido para quedarse, por lo que en esta investigación consideramos que un uso adecuado del enfoque competencial puede significar un gran avance en el sistema educativo. Así, teniendo en cuenta los criterios legislativos vigentes y centrándonos en la etapa de Educación Primaria, corresponde al cuerpo de maestros la labor de diseñar programaciones didácticas y de llevarlas a la práctica en el aula ordinaria a través de planteamientos metodológicos eficaces, es decir, que permitan que el 
alumnado adquiera las nombradas competencias clave y persigan una educación integral, fin último de la etapa de Educación Primaria.

Sin embargo, parece que la metodología de enseñanza y los planteamientos curriculares tradicionales aún imperantes en los tiempos actuales no resultan congruentes con la idea de un desarrollo competencial significativo (Bolívar, 2008; Couso y Adúriz-Bravo, 2016; Fernández March, 2006; Martínez Clares y Echeverría Samanes, 2009; Tiana Ferrer, 2011; Valle y Manso, 2013; Villa Sánchez y Poblete Ruiz, 2008; Zabala y Arnau, 2007), cuestión en la que parece existir un consenso en la literatura. De hecho, las carencias de aprendizaje gestadas bajo planteamientos metodológicos tradicionales se han venido haciendo patentes en diversas evaluaciones internacionales. Se acuerda con Gimeno Sacristán (2008) en no extralimitar la asignación de más capacidad que la mera de informar sobre algunos aspectos de la evaluación competencial a las pruebas estandarizadas y se posee consciencia de las limitaciones que encierran este tipo de pruebas ( $\mathrm{Au}, 2009$; McNeil, 2000). Por ello, dentro de un marco meramente descriptivo, lo que sí se puede afirmar es que fueron generosamente mediocres los resultados de España en ciencias (Martin, Mullis, Foy y Stanco, 2012) y en matemáticas (Mullis, Martin, Foy y Arora, 2012) en el estudio Trends in International Mathematics and Science Study (TIMSS) de 2011, que evaluó el rendimiento del alumnado de cuarto de Educación Primaria en estas dos materias. Asimismo, quedó comprobada la debilidad del alumnado a la hora de emplear destrezas de pensamiento o procedimientos, aspectos en los que obtuvieron los peores resultados en comparación con los conocimientos de hechos y conceptos (Ministerio de Educación, Cultura y Deporte [MECD], 2013a; 2013b). Más recientemente, los resultados en ciencias (Martin, Mullis, Foy y Hooper, 2016) y en matemáticas (Mullis, Martin, Foy y Hooper, 2016) reportados por el estudio TIMSS 2015, que mostraron un avance con respecto a los resultados anteriores, siguieron indicando que España seguía en una línea de resultados anodinos. Es más, existía un porcentaje superior a la media internacional de alumnado de Educación Primaria que solamente poseía conocimientos básicos en las áreas de ciencias y matemáticas e incluso seguía presentado ciertas dificultades a la hora de aplicar los conocimientos aprendidos a la situación práctica (MECD, 2016a).

Parecidos son los resultados, poco alentadores, que ha obtenido España en los estudios Progress in International Reading Literacy Study (PIRLS) (Mullis, 
Martin, Foy y Drucker, 2012; Mullis, Martin, Foy y Hooper, 2017; Mullis, Martin, Kennedy y Foy, 2007), que han evaluado en tres ocasiones la competencia lectora del alumnado de cuarto de Educación Primaria.

El estancamiento y la falta de progresión positiva del sistema educativo español, de los que también se hablaba en el Informe español del Programme for International Student Assessment (PISA) 2012 (MECD, 2014) se ha venido haciendo visible en el rendimiento en la competencia de ciencias, matemáticas y lectura desde los primeros resultados del Informe PISA 2000 (Organisation for Economic Co-operation and Development [OECD]/UNESCO Institute for Statistics, 2003). Esta evaluación mostró que las competencias del alumnado de 15 años en España estaban por debajo de la media de los países de la Organización para la Cooperación y el Desarrollo Económicos (OCDE), situación que no ha cambiado en ninguno de los informes sucesivos (OECD, 2004, 2007, 2010, 2014), salvo en el último (OECD, 2016), en que el alumnado ha experimentado una tendencia ligeramente positiva en matemáticas y en lectura con respecto a sus resultados en los anteriores informes, aunque solo consigue escalar por encima de la media de los países de la OCDE en lectura y no significativamente (MECD, 2016b). De nuevo recordar que, si bien los resultados de estas pruebas aportan información fructífera para la investigación educativa (Gil Pérez y Vilches, 2006), dadas sus limitaciones (Alcaraz Salarirche et al., 2013; Pérez y Soto, 2011; Yus Ramos et al., 2013) se deben interpretar con cautela.

Los últimos informes de resultados de las evaluaciones educativas nacionales que se hicieron públicos también proporcionaron datos preocupantes. En la evaluación general de diagnóstico de 2009 (Ministerio de Educación [ME], 2010), que evaluó el nivel alcanzado en cuatro competencias básicas — competencia en comunicación lingüística, competencia matemática, competencia en el conocimiento y la interacción con el mundo físico y competencia social y ciudadana- por el alumnado de cuarto curso de Educación Primaria se mostró que más del 40\% del alumnado se encontraba inmerso en los niveles bajos de rendimiento en las cuatro competencias evaluadas. Por su parte, la evaluación general de diagnóstico de 2010 (ME, 2011), que evaluó el nivel alcanzado en las mismas cuatro competencias básicas anteriores pero esta vez por el alumnado de segundo de ESO, arrojó parecidos resultados para esta muestra en todas las competencias evaluadas. 
Cada vez se está demostrando con más claridad que gran parte de los estudiantes no desarrolla adecuadamente las competencias. No solo se puede comprobar en estudios de evaluación nacionales o internacionales de alumnado perteneciente a etapas de escolarización obligatoria como los que se han nombrado. Desde el campo de la enseñanza de las ciencias en España también se ha hecho eco, concretamente, de las carencias del alumnado en cuanto al desarrollo de la competencia científica en las etapas de escolarización obligatoria (COSCE, 2011), alertándose, además, de que estas lagunas se siguen detectando en el contexto universitario. Al respecto, cabe destacar que, dentro del corpus de literatura especializada en este campo, también se han alzado numerosas voces mostrando la preocupación por el declive en el alumnado de una de las dimensiones de la competencia científica más estudiada, las actitudes hacia la ciencia (Marbà-Tallada y Márquez Bargalló, 2010; de Pro Bueno y Pérez Manzano, 2014; Vázquez Alonso y Manassero Mas, 2008). Esta cuestión también ha sido detectada a nivel internacional (Akpınar, Yıldız, Tatar, y Ergin, 2009; Ali, Yager, Hacieminoglu y Caliskan, 2013; George, 2006; Pell y Jarvis, 2001; Said, Summers, Abd-El-Khalick y Wang, 2016).

Por tanto, se puede inferir la existencia de un desconocimiento de aplicación metodológica que realmente ayude a desarrollar a buen nivel las competencias. Quizá por ello, desde European Commission (EC, 2007), el Informe Nuffield (Osborne y Dillon, 2008) o desde la misma COSCE (2011) ya se ha hecho alusión a la necesidad de encontrar alternativas innovadoras al estudio tradicional de las asignaturas de ciencias para inducir a los jóvenes a utilizar una visión científica en la resolución de problemas, cuestión ya detectada bastante tiempo atrás en España (Campanario y Moya, 1999; Carrascosa Alís y Gil Pérez, 1985; Gil Pérez, 1986) y que aquí se cree extensible a todas las asignaturas. De hecho, además de la diversidad de literatura ya citada, desde la propia legislación actual también se ha hecho alusión en numerosas ocasiones a la necesidad de este cambio metodológico (Decreto 26/2016, 2016; LOE, 2006; LOMCE, 2013; Orden ECD/65/2015, 2015; RD 1105/2014, 2014; RD 126/2014, 2014).

Parece pues, evidente, el consenso existente en la comunidad científica acerca de la necesidad de un cambio en la metodología tradicional de enseñanza. Sin embargo, el enfoque competencial en educación aún se encuentra en una fase incipiente (Díaz Barriga, 2013). Entre otros aspectos, la evaluación competencial ha quedado desatendida (Ramírez García, 2016; 
Roegiers, 2008), no existiendo todavía suficientes pruebas de una evaluación sistemática de los resultados del proceso de aplicación de las competencias (Gordon et al., 2009). Por ello, aunque existe gran variedad de publicaciones en torno a numerosos asuntos circundantes a este tópico que, hasta la fecha va en aumento, es posible comprobar que apenas existen trabajos más holísticos - menos aún en España - que estudien de qué forma la implementación de una metodología «transgresora» influye en la adquisición del conjunto de competencias clave y, en particular, de las intrínsecas a las áreas de ciencias, por parte del alumnado de Educación Primaria. La necesidad en España de investigar en esta línea, relacionada con la adquisición de las competencias clave en la Educación Primaria a través del cambio metodológico, lleva a abordar esta cuestión aquí de manera novedosa.

Conociendo ya la problemática existente se plantea una lógica incógnita: determinar por qué tipo de abordaje metodológico apostar para intentar que todo el alumnado, independientemente de sus gustos o destrezas iniciales, sea capaz de alcanzar esa serie de competencias clave indispensables para la vida y, en particular, las intrínsecas a las áreas de ciencias. En primer lugar, y en congruencia con el carácter integrador, transversal y dinámico característico del enfoque por competencias, parece lógico y adecuado tratar de traspasar los límites disciplinarios mediante la interrelación de diferentes áreas de conocimiento. En segundo lugar, es necesario considerar los estudios emergentes de la investigación en Didáctica de las Ciencias que han despertado en el alumnado intereses y actitudes postivas hacia el conocimiento y el estudio de las ciencias y, especialmente en aquel que en su inicio mostraba una baja predisposición. Así, se estima que, a priori, y dentro del abanico de enfoques metodológicos activos emergentes, la educación STEM - Science, Technology, Engineering y Mathematics — integrada (NRC, 2014) se muestra coherente con este cuadro y consonante con tales pretensiones. Se considera que propuestas didácticas enmarcadas en dicho referencial, basado en la interdisciplinariedad y transdisciplinariedad con la que debe tratarse el currículo de Educación Primaria, pueden favorecer que la mayor parte del alumnado alcance en mayor grado el conjunto de las competencias clave y, especialmente, las intrínsecas a las áreas de ciencias. Por ello, la investigación que se presenta se adhiere a esta línea, no obstante, va un paso más allá, apostando por la educación STEAM integrada, que supone la inclusión del arte a su precursor enfoque STEM. Como adelanto, destacar que la perspectiva STEAM parece 
implicar una visión más holística y equilibrada que la de STEM, cuestión que se retomará en el tercer capítulo.

Cabe destacar que el enfoque educativo STEAM ha sido recientemente propuesto y, aunque existen algunas implementaciones incipientes, sobre todo en las etapas de escolarización posteriores a la Educación Primaria, (Ata Aktürk y Demircan, 2017), no existen aún en la literatura estudios sobre sus efectos en el desarrollo competencial del alumnado de Educación Primaria.

\subsection{Establecimiento de las preguntas y de los objetivos de investigación}

Por tanto, derivadas de la anterior problemática se han establecido cuatro preguntas concretas para esta investigación. Se enumeran a continuación:

P 1- ¿Qué elementos son necesarios para construir una fundamentación teórica coherente para la educación STEM/STEAM integrada, enfocada a la potenciación del desarrollo competencial integral del alumnado de Educación Primaria?

P 2- ¿ंResulta plausible diseñar e implementar satisfactoriamente una unidad didáctica (UD) STEAM enfocada al desarrollo competencial en la etapa de Educación Primaria?

P 3- ¿Qué efectos produce la implementación de una UD STEAM integrada en el desarrollo competencial del alumnado de Educación Primaria?

P 4- ¿Qué panorama alternativo a la enseñanza tradicional se presenta prometedor para mejorar el desarrollo competencial del alumnado de Educación Primaria?

Para responder a cada una de estas cuatro preguntas de investigación se han establecido cuatro objetivos generales (OG) de los que se han derivado en determinados casos algunos objetivos específicos (OE) así como las correspondientes tareas $(\mathrm{T})$ a realizar. Todo ello se muestra a continuación:

OG 1. Establecer una fundamentación teórica robusta para la educación STEM/STEAM integrada, enfocada a la potenciación del desarrollo competencial integral del alumnado de Educación Primaria. 
OE 1.1. Elucidar la conceptualización y el alcance del término competencia en la etapa de Educación Primaria.

T 1. Realizar una revisión bibliográfica sistemática y crítica sobre la investigación acerca de las competencias en la Educación Primaria.

T 2. Analizar las diferentes implicaciones educativas del término competencia en la Educación Primaria.

OE 1.2. Determinar los fundamentos teóricos de la educación STEM/STEAM integrada y sus potencialidades para el desarrollo competencial en la Educación Primaria.

T 3. Revisar la historia de la educación STEM/STEAM integrada.

T 4. Examinar las implicaciones epistemológicas asociadas a la educación STEM/STEAM integrada.

T 5. Estudiar las características de la educación STEM/STEAM integrada y sus potencialidades para el desarrollo competencial en la Educación Primaria.

T 6. Construir un encuadre teórico para la educación STEM/STEAM integrada fundamentado desde la epistemología, la psicología y la didáctica que contemple los diversos aspectos que implica el término competencia y que se enfoque a potenciar su desarrollo integral en la Educación Primaria.

OG 2. Testar una UD STEAM en la etapa de Educación Primaria.

OE 2.1. Diseñar una UD STEAM coherente con la fundamentación teórica de la educación STEM/STEAM integrada anteriormente establecida.

T 7. Proponer el problema científico principal de la UD STEAM y seleccionar el conjunto de contenidos necesarios a abordar para su resolución.

T 8. Descubrir las representaciones del alumnado en cuanto a los contenidos seleccionados en la UD STEAM. 
T 9. Plantear los objetivos-representación derivados de las representaciones escogidas.

T 10. Planificar una secuencia de actividades que permita la fisura de las representaciones a través del abordaje de los contenidos seleccionados y la resolución del problema científico.

OE 2.2. Obtener información del desempeño y de las actitudes del alumnado derivada de la implementación de la UD STEAM en la Educación Primaria.

$\mathrm{T}$ 11. Implementar la UD STEAM en múltiples situaciones reales de aula de Educación Primaria y recoger información cualitativa y cuantitativa del desempeño y de las actitudes del alumnado.

OG 3. Determinar la influencia de la implementación de una UD STEAM en el desarrollo competencial del alumnado de Educación Primaria.

OE 3.1. Determinar la influencia de la implementación de una UD STEAM en el plano competencial general del alumnado de Educación Primaria.

T 12. Construir un diseño metodológico coherente y plausible para el análisis de la información obtenida.

T 13. Evaluar los resultados del alumnado en relación con los estándares de aprendizaje evaluables (EAE).

T 14. Deducir el nivel competencial del alumnado derivado de la evaluación de los EAE.

T 15. Analizar el efecto de la UD STEAM en el desarrollo competencial del alumnado de Educación Primaria.

OE 3.2. Determinar la influencia de la implementación de una UD STEAM en el plano actitudinal del alumnado de Educación Primaria.

T 16. Examinar la relación entre el cambio metodológico y el desarrollo de las actitudes hacia la ciencia en el alumnado de Educación Primaria. 
OE 3.3. Determinar si existe alguna relación entre el desarrollo competencial de la CMCT y las actitudes hacia la ciencia e intenciones hacia la ciencia, la ingeniería y su conjunto en el alumnado de Educación Primaria.

T 17. Averiguar si a mayor desarrollo de la CMCT se genera mayor desarrollo de las actitudes hacia la ciencia y la ingeniería en el alumnado de Educación Primaria.

OG 4. Proporcionar un panorama innovador en relación con la adquisición de las competencias clave en la Educación Primaria a través del cambio metodológico.

T 18. Recoger un conjunto de conclusiones novedosas acerca de las implicaciones educativas de la educación STEM/STEAM integrada en relación con su potencialidad para la mejora del desarrollo competencial del alumnado de Educación Primaria.

T 19. Determinar futuras líneas de investigación derivadas de los hallazgos de la investigación.

\subsection{Estructura de la investigación}

Después de esta introducción y habiéndose presentado las preguntas de investigación, los OG y los OE que focalizan el interés de la investigación y propuesto las tareas que orientan su desarrollo, se procede, a continuación, a esbozar la estructura que a partir de aquí seguirá el documento de tesis.

En aras de situar al lector sobre un panorama global de la investigación, se anticipa que el documento se ha estructurado en cuatro partes diferenciadas que, aunque se derivan de la secuenciación lógica de la propia investigación, poseen entidad por sí mismas, ya que han sido enfocadas a la consecución de cada uno de los cuatro OG propuestos y, por tanto, a la respuesta de las respectivas preguntas de investigación.

La primera parte, compuesta por los Capítulos 2, 3 y 4, está enfocada a la consecución del OG 1 y representa la fase de fundamentación teórica de la investigación. En el Capítulo 2, dirigido a la consecución del OE 1.1 y guiado por la T 1 y T 2, se presenta el encuadre teórico del término competencia y se ofrece una revisión sistemática sobre su investigación en la etapa de Educación 
Primaria. El Capítulo 3, encaminado a la consecución de parte del OE 1.2 y orientado por la T 3 y T4, revisa la historia de la educación STEM/STEAM integrada y examina las implicaciones epistemológicas que esta encierra. Con el Capítulo 4 se completa la consecución del OE 1.2 a través de la T5 y T6, exponiéndose una aproximación teórica a la interdisciplinariedad y a la educación STEM/STEAM para después plantear un encuadre teórico enfocado a potenciar el desarrollo competencial integral del alumnado de Educación Primaria.

La segunda parte consta del Capítulo 5 y se destina a la consecución del OG 2, representando la fase aplicada o práctica de la investigación. En el Capítulo 5, designado para la correspondiente consecución del OE 2.1 y OE 2.2 y guiado por la T7, T8, T9, T10 y T11, se presenta el diseño, se concreta la implementación de una UD enmarcada en la educación STEAM integrada que da lugar a la información cualitativa y cuantitativa necesaria para el posterior análisis de datos.

La tercera parte la conforman los Capítulos 6 y 7 y se enfoca a la consecución del OG 3. Es la parte que se corresponde con la fase del análisis de los datos y de la discusión de la investigación. Por tanto, en el Capítulo 6, encaminado a la consecución de parte del OE 3.1 y orientado por la T 12, se presenta la metodología seguida en la investigación. Con el Capítulo 7 se completa la consecución del OE 3.1, OE 3.2 y OE 3.3 a través de la T 13, T 14, T 15, T 16 y T 17, ejecutándose la evaluación de los resultados del alumnado, el análisis de los datos correspondientes a las distintas variables analizadas y la discusión de los hallazgos de la investigación.

La cuarta y última parte está constituida por el Capítulo 8 y, enfocada a la consecución del OG 4, se centra en concretar las principales conclusiones de la investigación. Así, en el Capítulo 8, guiado por la T 18 y T 19, se recoge un conjunto de implicaciones acerca de la potencialidad de la educación STEM/STEAM integrada para la mejora del desarrollo competencial del alumnado de Educación Primaria, finalizando con la determinación de algunas posibles futuras líneas de investigación derivadas de los hallazgos de esta tesis.

Por último, indicar que, aunque esta investigación se presenta estructurada de manera tradicional, se basa y ha derivado en diversas publicaciones que irán siendo citadas a lo largo de su desarrollo. 



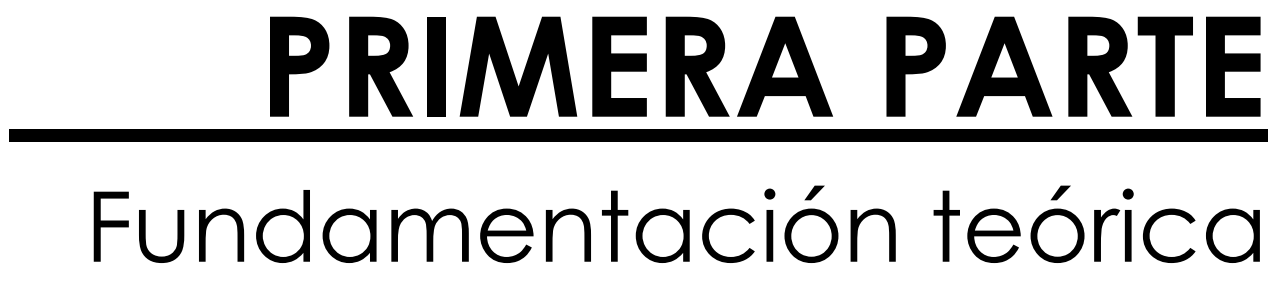





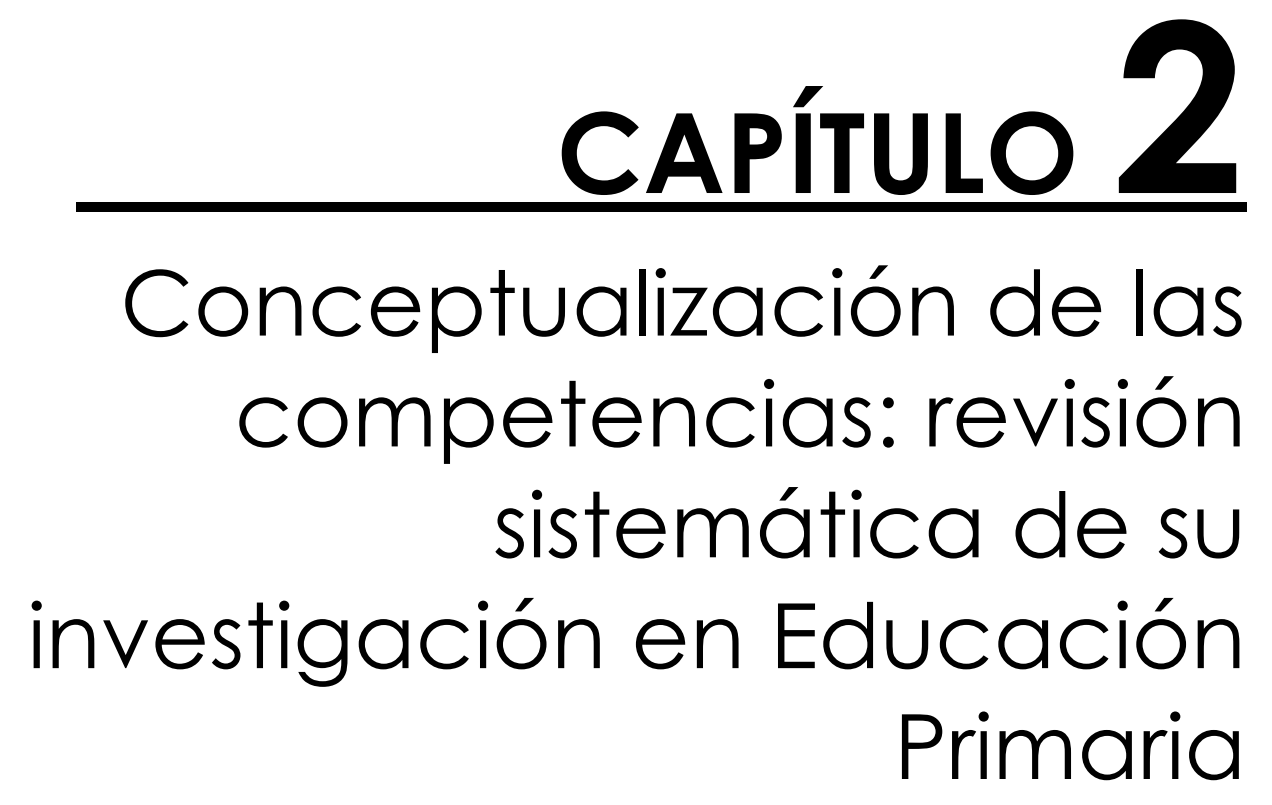





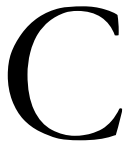

omenzando a cimentar la fundamentación teórica de esta investigación, este capítulo se ha enfocado a elucidar la conceptualización y el alcance del término competencia en la etapa de Educación Primaria. Para ello, se plantea la problemática existente, se presenta el encuadre teórico del término competencia y se ofrece una revisión bibliográfica sistemática y crítica sobre su investigación en la etapa de Educación Primaria.

Este capítulo se corresponde con el artículo de investigación que lleva el mismo título y que actualmente se encuentra en proceso de revisión. Por ello, se ha considerado adecuado presentarlo manteniendo la estructura del propio artículo. Solamente se han omitido las referencias bibliográficas, que se presentan compiladas en el Capítulo 9. Así mismo, este capítulo contiene información de algunos trabajos preliminares realizados en torno a esta temática (Ortiz-Revilla, Greca y Adúriz-Bravo, 2018a, 2018b, 2018c).

\subsection{Resumen}

El estudio de las competencias registra una amplia trayectoria investigadora. Sin embargo, en los últimos años, tanto este concepto como su andamiaje teórico han suscitado algunas cuestiones relevantes que deben ser reconsideradas. El propósito de esta investigación es revelar información existente en la literatura para ayudar a elucidar la conceptualización de competencia y a comprender su significatividad en el sistema educativo actual, fundamentalmente en la etapa de Educación Primaria. Se presenta una síntesis del surgimiento y evolución del constructo y una revisión sistemática sobre su investigación en Educación Primaria. Los resultados apuntan a la década de 2010 como el periodo con más producción científica, con una tendencia al alza. En cuanto al perfil general de publicaciones, tres cuartos de la muestra corresponden a artículos de corte empírico y la mayoría se ubican en el continente europeo, siendo España el país que encabeza la lista. El análisis en profundidad revela que casi el total de los estudios aborda las dimensiones competenciales más tradicionales; es pequeño el subconjunto que trata una mayor variedad de dimensiones. La vertiente conceptual que asume las competencias desde una mirada técnica/profesionalizante supone una mayoría, frente a una visión más humanista/formadora. Solo un cuarto muestral presenta definiciones propias del término, versus tres cuartas partes que 
adoptan marcos teóricos ya consolidados. A la luz de estos resultados, se considera que en la literatura todavía se encuentra una visión poco meditada del constructo. Todos estos hallazgos podrían ayudar a desarrollar propuestas didácticas más coherentes con las necesidades educativas actuales.

\subsection{Introducción y planteamiento del problema}

En el ámbito de la educación, y concretamente en el entorno de las instituciones educativas, tanto el concepto de competencia como su andamiaje representan un núcleo de interrogantes sobresalientes, siendo necesario reconsiderar numerosas cuestiones y recapacitar sobre su alcance.

El estudio de las competencias se remonta a varias décadas. Desde que Chomsky (1965) introdujo el concepto de competencia lingüística, muchas han sido las acepciones atribuidas al término competencia. Zabala y Arnau (2007) definieron competencia como «la intervención eficaz en los diferentes ámbitos de la vida mediante acciones en las que se movilizan, al mismo tiempo y de manera interrelacionada, componentes actitudinales, procedimentales y conceptuales» (p. 45). Gimeno Sacristán (2008) aludió a la poca meditación en las aplicaciones de lo que denomina un nuevo lenguaje, cuestión que se ha seguido recalcando (Rosselló Ramón y Pinya Medina, 2014). Para Sanmartí Puig (2011) la competencia no constituye una nueva forma de burocracia, sino que supone una evolución sustancial con respecto a la concepción curricular tradicional de saberes conceptuales, procedimentales y actitudinales.

Lo cierto es que en España - entre otros países-, las competencias se han ido asentando como un elemento curricular cada vez más protagonista hasta el punto de ser obligatoria, en la actualidad, su integración curricular. Sin embargo, se evidencia la inseguridad al abordarlas didácticamente (Díaz Barriga, 2013), por ejemplo, en su evaluación (Ramírez García, 2016). Si se asume el carácter pluridimensional de su entramado, contemplar las competencias metodológicamente supone cambiar el modo de concebir el proceso de enseñanza.

El marco teórico competencial no es reducido, muchos estudios han tratado este constructo en el ámbito educativo (e.g., Coll, 2007; EC, 2017; European Parliament and Council, 2006; Eurydice, 2002; Gordon et al., 2009; Perrenoud, 2009; Sarramona, 2000; Tardif, 2006). También se ha trabajado 
desde la visión del ámbito profesional (Navío, 2005; Tejada Fernández, 2011) y, por ende, en el ámbito profesional educativo (Domingo Segovia, Gallego Ortega, García Aróstegui y Rodríguez Fuentes, 2010; Perrenoud, 1999). Sin embargo, el concepto de competencia provino del ámbito laboral, donde se desarrollaron numerosos estudios (e.g., Le Boterf, 1998; McClelland, 1973; Mertens, 1996). Por ello, a menudo se entremezclan diferentes definiciones que no ayudan a aclarar su significado educativo (De Ketele, 2008; López Gómez, 2016) y muchas concepciones superficiales distan bastante de la propuesta académico-profesional para el alcance competencial.

Para comprender la significatividad del entramado competencial en el sistema educativo actual y en particular en la etapa de Educación Primaria, resulta relevante examinar las aportaciones que desde el ámbito de la investigación se han ido realizando. Este estudio presenta una revisión sistemática sobre la investigación acerca de las competencias en la etapa de Educación Primaria. Mediante esta revisión se pretende sacar a la luz información relevante con el objetivo de proporcionar a la comunidad de investigadores y maestros un conocimiento que podría ayudar a elucidar la conceptualización de competencia y a plantear propuestas didácticas más acordes con las necesidades educativas actuales.

\subsection{Encuadre teórico del término competencia}

En esta sección se sintetizan las contribuciones de los dos organismos internacionales —OCDE y UNESCO— considerados los mayores aportadores a la construcción del concepto de competencia en el ámbito educativo, al ser los responsables de proporcionar los cimientos sobre los que el Marco Europeo de Referencia basó el desarrollo de las denominadas competencias clave (Pepper, 2011).

\subsubsection{La OCDE}

Hace más de 30 años, la Organización para la Cooperación y el Desarrollo Económicos (OCDE) lanzó el proyecto Indicators of National Education Systems (INES) con el objetivo principal de mejorar la recolección de información en 
el ámbito educativo para su posterior presentación pública (Salganik, Rychen, Moser y Konstant, 1999). Dentro de INES, con ánimo de desarrollar un marco conceptual más concreto y de crear nuevos parámetros de medición competencial y desarrollo del aprendizaje poblacional, se desarrollaron los proyectos Cross-Curricular Competencies (CCC), International Adult Literacy Survey (IALS) y Human Capital Indicators (HCI).

A raíz de estos fueron surgiendo otros que continuaron moldeando el concepto de competencia, como PISA y TIMSS, que incentivaron paulatinamente el avance teórico desde distintos enfoques. Puntualizar que, aunque es evidente la aportación conceptual de estos proyectos, algunos autores ya han advertido de una incongruencia entre su conceptualización teórica y la aplicación práctica que llevan a cabo, por ejemplo, en las pruebas PISA (Gallardo-Gil et al., 2010).

En 1997 la OCDE lanzó el proyecto Definition and Selection of Competencies (DeSeCo), del cual emana la concepción competencial europea. El primer informe de DeSeCo mostró el descuido teórico de los proyectos precedentes y para cubrir este vacío se exploraron las numerosas concepciones teóricas y pragmáticas disponibles. El informe final concluyó recomendando un enfoque funcional como base conceptual para las comparaciones del desempeño escolar. Se trataba de un sistema de habilidades, conocimientos, estrategias y metacogniciones aprendidas (Weinert, 1999). Posteriormente, se elaboraron cinco informes de expertos con diferentes visiones competenciales (Rychen y Salganik, 2001) proponiendo una definición de competencia como «la capacidad de satisfacer con éxito las demandas individuales o sociales, o de llevar a cabo una actividad o tarea» (OECD, 2002, p. 8). Así, se aclaró que las competencias solo eran observables en algunas acciones de los individuos, se adquirían formal e informalmente a lo largo de la vida, las competencias clave eran aquellas aplicables en múltiples áreas y dependientes de cada contexto social (OECD, 2002). Dada la necesidad de formar ciudadanos desenvueltos en el mundo actual (Rychen y Salganik, 2003), se consolidaron tres amplias categorías interrelacionadas de competencias clave: usar herramientas de manera interactiva, actuar de forma autónoma e interactuar en grupos heterogéneos (OECD, 2005).

Desde la primera concepción de competencia como destreza (Salganik et al., 1999) hasta su concreción —incluyendo la separación de los términos skill como habilidad para realizar acciones y competency como sistema de acción 
complejo (OECD, 2002, 2005; Rychen y Salganik, 2001, 2003)—, se puede apreciar el gran avance producido. A la luz de lo expuesto, parece coherente pensar que el nacimiento del entramado competencial se enmarca en la década de los noventa.

\subsubsection{La UNESCO}

Paralelamente a este desarrollo, es necesario destacar el aporte que el Informe a la UNESCO por parte de la Comisión Internacional sobre la Educación para el Siglo XXI (Delors, 1996) produjo en la conceptualización de las competencias. En el informe, cuyo trasfondo era instaurar ante los nuevos desafíos el concepto de una educación para toda la vida, se propusieron cuatro pilares educativos básicos: aprender a conocer, aprender a hacer, aprender a ser y aprender a vivir juntos. Así, dentro del papel adoptado por la UNESCO de defensa de una educación humanista, la competencia de un individuo comprende diferentes parámetros de desarrollo personal. Según Adúriz-Bravo, Merino, Jara, Arellano y Ruiz (2012), «desde este marco de ideas, podríamos decir que se 'es' ciudadano de pleno derecho cuando se 'hace' poniendo en acción lo que se 'sabe' en contextos en los que 'se convive' con personas» ( $\mathrm{p}$. $30)$.

En la actualidad, este mismo organismo sigue haciendo hincapié en la necesidad del desarrollo competencial en el denominado Marco de Acción Educación 2030 (UNESCO, 2016). En su informe, encargado a este organismo por su especialización en educación, se otorgó un papel principal a las competencias para garantizar una educación inclusiva y equitativa de calidad y promover oportunidades de aprendizaje permanente para todos, reforzando la idea de la necesidad de una educación básica como pasaporte para toda la vida.

\subsection{Metodología}

Después de esta aproximación a la trayectoria de la conceptualización de las competencias, se presenta una revisión exhaustiva planteada con el objetivo de recopilar información relevante, crítica y rigurosa existente en la literatura 
especializada sobre la investigación acerca de este constructo en la etapa de Educación Primaria.

La metodología utilizada se adhiere a la línea de las revisiones sistemáticas, que difieren de las revisiones narrativas tradicionales en ser menos propensas al sesgo, más objetivas y detalladas, más rigurosas y explícitas en los criterios de inclusión de estudios. Es la intención de las revisiones sistemáticas transparentar aspectos de su proceso para hacerlo reproducible para los investigadores (Bennett, Lubben, Hogarth y Campbell, 2005). Concretamente, la presente revisión se guio por la lógica y las etapas básicas propuestas por el EPPI-Centre para toda revisión sistemática (Bennett et al., 2005; Gough, Oliver y Thomas, 2013). Además, con ánimo de corroborar la presentación de una revisión sistemática transparente, se aseguró el cumplimiento de la lista de verificación propuesta por PRISMA para informar revisiones sistemáticas (Liberati et al., 2009; Moher, Liberati, Tetzlaff y Altman, 2009).

\subsubsection{Diseño y procedimiento}

Los estudios incluidos en esta revisión sistemática fueron seleccionados mediante una búsqueda en la base de datos de la Colección Principal de Web of Science. También fue realizada una búsqueda aplicada a un amplio número de revistas de justificada calidad.

La combinación de palabras introducida en la opción de búsqueda básica de la base de datos fue dividida en dos campos. En el primero, título, se introdujo la combinación competenc* OR skill*. En el segundo, tema, se tecleó "primary education" OR "elementary education" OR "basic education" OR "primary school” OR "elementary school' OR "basic school'. Esta búsqueda, correspondiente a la primera fase de la revisión sistemática, se realizó utilizando criterios relativamente amplios con la pretensión de aumentar su validez (Bennett, Lubben y Hogarth, 2007). La elección de estas combinaciones se determinó atendiendo a la frecuencia de uso en la literatura, así como a la rigurosidad terminológica proporcionada por el tesauro de la UNESCO. Para construir la combinación competenc* OR skill* se añadió el signo asterisco (*) al final de cada término, con el interés de abarcar todas las variantes existentes de desinencia (Navío, 2005). 
La primera búsqueda formalizada reportó 2059 resultados. A continuación, se procedió a refinar el conjunto seleccionando las categorías Education Educational Research, Education Scientific Disciplines, Education Special y Psychology Educational — que a su vez englobaban todos los documentos recogidos en el área de investigación Education Educational Research de Web of Science- obteniendo 1281 resultados. Se aplicó el filtro tipos de documento, seleccionando article y review. Con este proceso, la base de datos arrojó 919 resultados y tras eliminar aquellos no pertenecientes a revistas indizadas en el ranking de calidad Journal Citation Reports (JCR), se procesaron finalmente 688 resultados; 679 artículos y nueve revisiones.

Con el fin de cubrir posibles brechas temporales de la base de datos y conformar una revisión más completa, se realizó una búsqueda adicional en algunas revistas consideradas relevantes en educación. Se revisaron posibles artículos incluidos en las plataformas ScienceDirect de Elsevier, Taylor\&Francis Online y en la editorial Wiley, abarcando un total de 157 revistas indizadas en alguna categoría de educación del ranking JCR. Adicionalmente, para aumentar la muestra de estudios que aportasen luz a la conceptualización de las competencias en España, se consideró conveniente realizar una última exploración en algunas revistas españolas de alta relevancia en educación, no necesariamente indizadas en JCR, pero incluidas en la plataforma RESH como las 20 revistas de mayor impacto. Así, se inspeccionaron las siguientes revistas: Alambique, Cultura y Educación, Didáctica de las Ciencias Experimentales y Sociales, Educación XX1, Edupsykhé, Enseñanza de las Ciencias, Estudios sobre Educación, Infancia y aprendizaje, Investigación en la Escuela, PSRI, RECIEM, RELIEVE, REMA, REOP, Revista Española de Pedagogía, Revista de Educación, Revista de Investigación en Educación, Revista de Psicodidáctica, RIE y Teoría de la Educación. Revista Interuniversitaria.

De estos procesos se extrajeron 127 artículos más —85 entre ScienceDirect, Taylor\&Francis Online y Wiley y 42 de RESH - que fueron incorporados a los 688 resultados localizados anteriormente.

Después de la lectura del título, resumen y palabras clave de los 815 documentos, se seleccionaron 77 de ellos — 75 artículos y dos revisiones- de acuerdo con los siguientes criterios de inclusión:

- Los estudios se refieren a la etapa de Educación Primaria tal y como se concibe en España - i.e., edades entre 6-12 años-. 
- Los artículos estudian aspectos de las competencias referidas exclusivamente al alumnado.

En esta segunda fase se excluyeron artículos enfocados a las etapas de infantil, secundaria y universitaria, encaminados al estudio de destrezas, dirigidos al colectivo del profesorado y orientados al estudio de la autocompetencia, cuestiones alejadas de esta investigación. Esta fase se desarrolló con especial detenimiento para contribuir a garantizar la fiabilidad del corpus. En los casos que suscitaron dudas se leyó el artículo completo. Además, con el fin de asegurar la rigurosidad de los criterios de inclusión, es decir, de comprobar que estos criterios estuviesen siendo interpretados y aplicados sistemáticamente (Bennett et al., 2005), un segundo evaluador analizó un $10 \%$ de los 815 documentos iniciales. El coeficiente inter-evaluador de los jueces fue muy alto: se coincidió en la exclusión o inclusión de 81 de los 82 artículos sometidos a doble evaluación. Esto demostró que los criterios iniciales eran robustos y proporcionaban una alta fiabilidad de inclusión. Con el artículo que produjo discrepancias se estableció un acuerdo entre los evaluadores.

En la tercera y última fase, se procedió a la lectura completa de los 77 estudios seleccionados, donde fueron aplicados los siguientes criterios de exclusión:

- Artículos centrados en el estudio de la competencia asimilada desde la concepción tradicional de habilidad.

- Artículos que no contribuyen a la definición de la competencia -i.e., a comprender el concepto-, ya sea porque no la estudian en profundidad y de manera específica o porque su referencia al constructo supone una parte reducida o insustancial del estudio.

Este proceso fue repetido una segunda vez en un intervalo de tres meses obteniéndose idénticos resultados, lo que nuevamente confirmó la robustez de los criterios empleados.

Dada la subjetividad que podía presentar el segundo criterio de exclusión de esta tercera fase, este se efectivizó a partir de un trabajo de síntesis, refinado y reformulación aplicado sobre los siete elementos propuestos por Adúriz-Bravo et al. (2012) como comunes en la conceptualización competencial, construyendo las siete dimensiones competenciales de las que se derivan los criterios operativos (ver Tabla 2.1). Así, se estableció como criterio de exclusión operativo el no tratamiento de al menos dos dimensiones 
competenciales — con las particularidades que se especifican en el siguiente apartado-, asegurando de manera más objetiva y rigurosa que los estudios incluidos en la revisión final contaran con una cierta profundidad teórica.

Se descartaron diez artículos con la aplicación del primer criterio de exclusión y 29 con el segundo. Por ejemplo, el trabajo de Wentzel (1991), que estudió la relación entre las habilidades de responsabilidad social y el logro académico o el de Barrios Espinosa y Morales Orozco (2012), cuyo propósito fue diagnosticar el desarrollo de competencias curriculares más que su conceptualización, fueron excluidos en esta fase. Quedaron 38 estudios que demostraron tener un perfil apropiado para la revisión en profundidad, donde se analizaron cuestiones consideradas relevantes para la investigación, como la variedad de dimensiones competenciales estudiadas, la vertiente conceptual adoptada y la presencia o ausencia de definiciones propias del concepto.

\subsubsection{Instrumento de análisis}

En la Tabla 2.1 se muestra pormenorizadamente el instrumento que sirvió tanto de base para el segundo criterio de exclusión de la última fase como para determinar la variedad de dimensiones competenciales abordadas en los artículos analizados en profundidad. 
Tabla 2.1. Síntesis de las dimensiones competenciales y sus criterios operativos

Elementos iniciales propuestos por Adúriz-Bravo et al. (2012)

1. Un saber con significado y sentido. Saber que se aprehende de manera comprensiva, contextualizado en la realidad que envuelve al sujeto.

2. Un saber hacer eficaz $y$ transformador. Saber hacer que se manifiesta en un escenario que permite contrastar, a partir de la acción del sujeto, niveles de eficiencia, aplicación y transferencia de los saberes aprendidos en el contexto escolar.

3. Un conjunto de actitudes y valores. Disposiciones, juicios y emociones del sujeto para querer aprender, participar y movilizar sus recursos al ser requeridos en la intervención de la situación concreta.

4. Un contexto específico. Contexto en el cual tiene significatividad la competencia, por ser la situación concreta de intervención y de manifestación de la actividad competente del sujeto.
Dimensiones competenciales y criterios operativos construidos

1. Un saber consciente y con sentido.

- El artículo proporciona una visión del saber disciplinar como herramienta para dar sentido al mundo.

2. Un saber hacer eficaz cuyos niveles de eficiencia se pueden ir contrastando.

- El artículo incluye el requisito de la transferencia de los saberes aprendidos.

3. Un conjunto de actitudes y valores puestos en juego al intervenir en cada situación.

- El artículo aborda una visión valórica o ética del sujeto aplicada a situaciones.

4. Un contexto o escenario específico de la realidad del sujeto en el que la competencia adquiere significatividad.

- El artículo contempla sustantivamente la variable contexto del problema sobre el cual se actúa. 
5. Solvencia comunicativa. Capacidad de producción de textos en diversos formatos que comunican la acción eficaz y las razones que la sustentan.

6. Conciencia y comprensión de lo que se hace. Mecanismos que permiten simultáneamente la acción, su control, su regulación y su evaluación.

7. Una determinada imagen de ciencia. Imagen alejada del cientificismo dogmático y cercana a valores humanistas y culturales compartidos.
5. Solvencia comunicativa.

- El artículo contempla la comunicación del saber.

6. Consciencia.

- El artículo contempla aspectos metacognitivos de la acción.

7. Naturaleza del conocimiento disciplinar.

- El artículo incorpora una perspectiva sobre la naturaleza del conocimiento disciplinar.

Con el fin de agilizar su tratamiento, la mayoría de las dimensiones competenciales fue sintetizada a partir de los elementos iniciales. Sin embargo, en vez de refinada, la séptima dimensión fue generalizada de su elemento predecesor, al constituir este un componente específico de la competencia científica.

Se estableció como segundo criterio de exclusión operativo de la tercera fase el no tratamiento de la segunda dimensión competencial construida y al menos de otra de las propuestas.

\subsection{Resultados}

\subsubsection{Panorama amplio de los estudios dedicados al constructo competencial en Educación Primaria}

Después de la aplicación de los primeros criterios de inclusión en la segunda fase de la revisión sistemática, ya fue posible establecer un panorama general en cuanto a la distribución temporal de los 77 estudios seleccionados. En la Figura 2.1 se muestra una relación de la producción científica por quinquenio 
en las tres últimas décadas - en el último quinquenio se abarca hasta el mes de octubre de 2018, fecha en la que se finalizó el proceso de búsqueda del presente estudio- que, de una manera u otra, se refiere al constructo competencial en la Educación Primaria, abordándolo con cierta profundidad o contemplando algunos aspectos que pueden formar parte de su entramado.

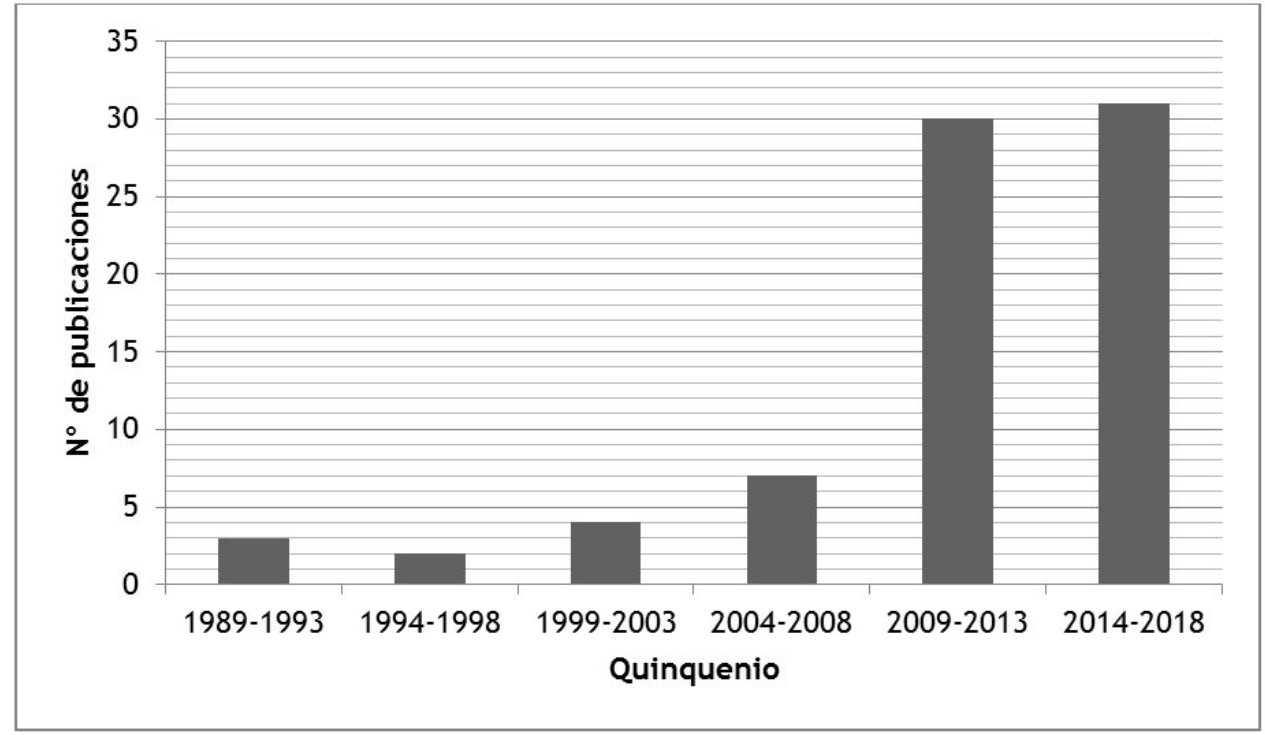

Figura 2.1. Distribución de publicaciones por quinquenio.

Es fácilmente apreciable el aumento progresivo de la producción científica a lo largo de las últimas tres décadas (1989-1998 $n=5$; 1999-2008 $n$ = 11; 2009-2018 $n=61$ ), distinguiéndose el surgimiento del entramado competencial en la década de 1990, tal y como se comentó al inicio. No obstante, el gran salto hacia el incremento de la producción científica llegó algunos años más tarde, siendo evidente su crecimiento en la década de 2010. Esta tendencia al alza se conserva hasta el último quinquenio (2014-2018 $n=$ 31). Es posible que este aumento esté relacionado con la centralidad que últimamente se está otorgando al desarrollo de las competencias dentro del currículo de Educación Primaria, como en el caso de España. 


\subsubsection{Descripción general de los estudios finales}

A pesar de que la educación basada en competencias atraviesa una época de auge, el número de estudios finalmente obtenidos después de aplicar los criterios de inclusión y exclusión de la revisión no es tan alto como, a priori, se esperaba. Esto ya constituye una primera conclusión per se.

La Tabla 2.2 presenta una relación de los 38 estudios finales - cuyo listado de referencias bibliográficas se encuentra en el apéndice- atendiendo al país en el que se desarrollaron, al tipo de estudio, a la revista a la que pertenecen y a la competencia que indican tratar.

Tabla 2.2. Mapeo general de los estudios finales

\begin{tabular}{|c|c|c|c|c|}
\hline Estudio & País & Tipo & Revista & Competencia \\
\hline Aesaert y van Braak (2015) & Bélgica & $\mathrm{E}$ & $\begin{array}{l}\text { COMPUT } \\
\text { EDUC }\end{array}$ & TIC \\
\hline $\begin{array}{c}\text { Aesaert, van Braak, van } \\
\text { Nijlen y Vanderlinde } \\
\text { (2015) }\end{array}$ & Bélgica & $\mathrm{E}$ & $\begin{array}{l}\text { COMPUT } \\
\text { EDUC }\end{array}$ & TIC \\
\hline $\begin{array}{l}\text { Aesaert, van Nijlen, } \\
\text { Vanderlinde, Tondeur, } \\
\text { Devlieger y van Braak } \\
(2015)\end{array}$ & Bélgica & $\mathrm{E}$ & $\begin{array}{l}\text { COMPUT } \\
\text { EDUC }\end{array}$ & TIC \\
\hline $\begin{array}{l}\text { Aesaert, van Nijlen, } \\
\text { Vanderlinde y van Braak } \\
\text { (2014) }\end{array}$ & Bélgica & $\mathrm{E}$ & $\begin{array}{l}\text { COMPUT } \\
\text { EDUC }\end{array}$ & TIC \\
\hline $\begin{array}{c}\text { Andreu Duran y Godall } \\
\text { Castell (2012) }\end{array}$ & España & $\mathrm{E}$ & REV EDUC & General \\
\hline $\begin{array}{l}\text { Andreu Duran, Godall } \\
\text { Castell, Amador Guillem y } \\
\text { Castro Morera (2017) }\end{array}$ & España & $\mathrm{E}$ & $\begin{array}{l}\text { INT J MUSIC } \\
\text { EDUC }\end{array}$ & General \\
\hline $\begin{array}{l}\text { de la Caba Collado y } \\
\text { López Atxurra (2005) }\end{array}$ & España & $\mathrm{E}$ & REV EDUC & Ciudadana \\
\hline Cha et al. (2011) & $\begin{array}{l}\text { Corea del } \\
\text { Sur }\end{array}$ & $\mathrm{E}$ & $\begin{array}{l}\text { COMPUT } \\
\text { EDUC }\end{array}$ & TIC \\
\hline $\begin{array}{c}\text { Dabrowski y Wiśniewski } \\
(2011)\end{array}$ & Polonia & $\mathrm{T}$ & EUR J EDUC & General \\
\hline $\begin{array}{l}\text { Dijkstra, Geijsel, Ledoux, } \\
\text { van der Veen y ten Dam } \\
(2015)\end{array}$ & Holanda & $\mathrm{E}$ & $\begin{array}{c}\text { SCH EFF } \\
\text { SCH IMPROV }\end{array}$ & Ciudadana \\
\hline España, Cabello y Blanco & España & $\mathrm{T}$ & ENS CIENC & Alimentación \\
\hline González Aguado (2017) & España & $\mathrm{T}$ & ALAMBIQUE & Científica \\
\hline Guarro Pallás (2008) & España & $\mathrm{T}$ & INVEST ESC & General \\
\hline $\begin{array}{c}\text { Hernández-Bravo, } \\
\text { Cardona-Moltó y } \\
\text { Hernández-Bravo (2016) }\end{array}$ & España & $\mathrm{E}$ & $\begin{array}{l}\text { MUSIC } \\
\text { EDUC RES }\end{array}$ & Musical \\
\hline de Juanas Oliva, Ezquerra & España & $\mathrm{E}$ & INVEST ESC & General \\
\hline
\end{tabular}




\begin{tabular}{|c|c|c|c|c|}
\hline & País & Tipo & Revista & Competencia \\
\hline $\begin{array}{l}\text { Martínez, Martín del Pozo } \\
\text { y Pesquero Franco (2012) }\end{array}$ & & & & \\
\hline Letina (2016) & Croacia & $\mathrm{E}$ & $\begin{array}{l}\text { CROAT J } \\
\text { EDUC }\end{array}$ & Científica \\
\hline $\begin{array}{l}\text { Lozano-Martínez y } \\
\text { Alcaraz-García (2011) }\end{array}$ & España & $\mathrm{E}$ & EDUC XX1 & Emocional \\
\hline Mayós (2003) & España & $\mathrm{T}$ & ALAMBIQUE & General \\
\hline $\begin{array}{l}\text { Méndez-Giménez, Sierra- } \\
\text { Arizmendiarrieta y } \\
\text { Mañana-Rodríguez (2013) }\end{array}$ & España & $\mathrm{E}$ & REV EDUC & General \\
\hline $\begin{array}{l}\text { Miralles Martínez, Gómez } \\
\text { Carrasco y Monteagudo } \\
\text { Fernández }\end{array}$ & España & $\mathrm{E}$ & INVEST ESC & $\begin{array}{l}\text { Social y } \\
\text { ciudadana }\end{array}$ \\
\hline Pepper (2011) & Inglaterra & $\mathrm{T}$ & EUR J EDUC & General \\
\hline $\begin{array}{l}\text { Pesakovic, Flogie y } \\
\text { Aberšek (2014) }\end{array}$ & Eslovenia & $\mathrm{E}$ & $\begin{array}{l}\text { J BALT SCI } \\
\text { EDUC }\end{array}$ & General \\
\hline Pinos (2016) & España & $\mathrm{E}$ & INVEST ESC & Lingüística \\
\hline de Pro Bueno (2011) & España & $\mathrm{T}$ & INVEST ESC & Científica \\
\hline $\begin{array}{c}\text { de Pro Bueno y Rodríguez } \\
\text { Moreno (2010) }\end{array}$ & España & $\mathrm{E}$ & ENS CIENC & General \\
\hline $\begin{array}{c}\text { Puig Gutiérrez y Morales } \\
\text { Lozano (2012) }\end{array}$ & España & $\mathrm{T}$ & $\begin{array}{l}\text { REV ESP } \\
\text { PEDAGOG }\end{array}$ & Social y Cívica \\
\hline $\begin{array}{l}\text { Puig Gutiérrez y Morales } \\
\text { Lozano (2015) }\end{array}$ & España & $\mathrm{E}$ & EDUC XX1 & Social y Cívica \\
\hline $\begin{array}{c}\text { Ramírez-García y } \\
\text { González-Fernández } \\
\text { (2016) }\end{array}$ & España & $\mathrm{E}$ & COMUNICAR & Mediática \\
\hline $\begin{array}{l}\text { Ramírez-García y Pérez } \\
\text { del Arco (2013) } \\
\text { Ramírez-García, Renés }\end{array}$ & España & $\mathrm{E}$ & CULT EDUC & General \\
\hline $\begin{array}{c}\text { Arellano y García Ruiz } \\
\text { (2014) }\end{array}$ & España & $\mathrm{T}$ & TEOR EDUC & Mediática \\
\hline $\begin{array}{l}\text { Romero Fernández, } \\
\text { Rodríguez Miranda y de las } \\
\text { Heras Pérez (2013) }\end{array}$ & España & $\mathrm{E}$ & INVEST ESC & General \\
\hline $\begin{array}{c}\text { Salmerón Pérez, } \\
\text { Gutiérrez-Braojos, } \\
\text { Rodríguez Fernández y } \\
\text { Salmerón Vílchez }(2010)\end{array}$ & España & $\mathrm{E}$ & REOP & $\begin{array}{l}\text { Aprender a } \\
\text { Aprender }\end{array}$ \\
\hline Sarramona (2014) & España & $\mathrm{E}$ & TEOR EDUC & General \\
\hline $\begin{array}{l}\text { Stewart-Brown y } \\
\text { Edmunds (2003) }\end{array}$ & & $\mathrm{T}$ & $\begin{array}{l}\text { PERSPECT } \\
\text { EDUC }\end{array}$ & $\begin{array}{l}\text { Emocional y } \\
\text { Social }\end{array}$ \\
\hline $\begin{array}{c}\text { Tiana, Moya y Luengo } \\
(2011)\end{array}$ & España & $\mathrm{T}$ & EUR J EDUC & General \\
\hline $\begin{array}{l}\text { Trentacosta, Izard, } \\
\text { Mostow y Fine (2006) }\end{array}$ & Delaware & $\mathrm{E}$ & $\begin{array}{l}\text { SCHOOL } \\
\text { PSYCHOL } \\
\text { QUART }\end{array}$ & $\begin{array}{l}\text { Emocional y } \\
\text { Atencional }\end{array}$ \\
\hline $\begin{array}{c}\text { Vicente, Rosales, Chamoso } \\
\text { y Múñez (2013) }\end{array}$ & España & $\mathrm{E}$ & CULT EDUC & Matemática \\
\hline Yao y Guo (2018) & China & $\mathrm{E}$ & $\begin{array}{l}\text { INT J SCI } \\
\text { EDUC }\end{array}$ & Científica \\
\hline
\end{tabular}

Nota. $\mathrm{T}=$ Teórico; $\mathrm{E}=$ Empírico. 
Se observa, geográficamente, que casi el total de publicaciones están ubicadas en el continente europeo. España $(n=25)$ es el país con mayor número de publicaciones que tratan el constructo competencial en la etapa de Educación Primaria, seguida de lejos por Bélgica $(n=4)$, Inglaterra $(n=2)$ y una fila de países representados con un artículo - Holanda, Croacia, Eslovenia y Polonia-. Las únicas porciones muestrales que pertenecen a otro continente distinto al europeo son las de Corea del Sur, Delaware —Estados Unidos- y China, representadas con un estudio. Conocemos la limitación de estos datos en cuanto a la alta representación de España. No obstante, incluso eliminando la porción de muestra extraída de las revistas incluidas en la plataforma RESH, el valor de España pasa a ser $n=11$, resultado aún dominante entre la muestra total. La Figura 2.2 exhibe una relación del número de publicaciones y su país de procedencia utilizando los datos depurados.

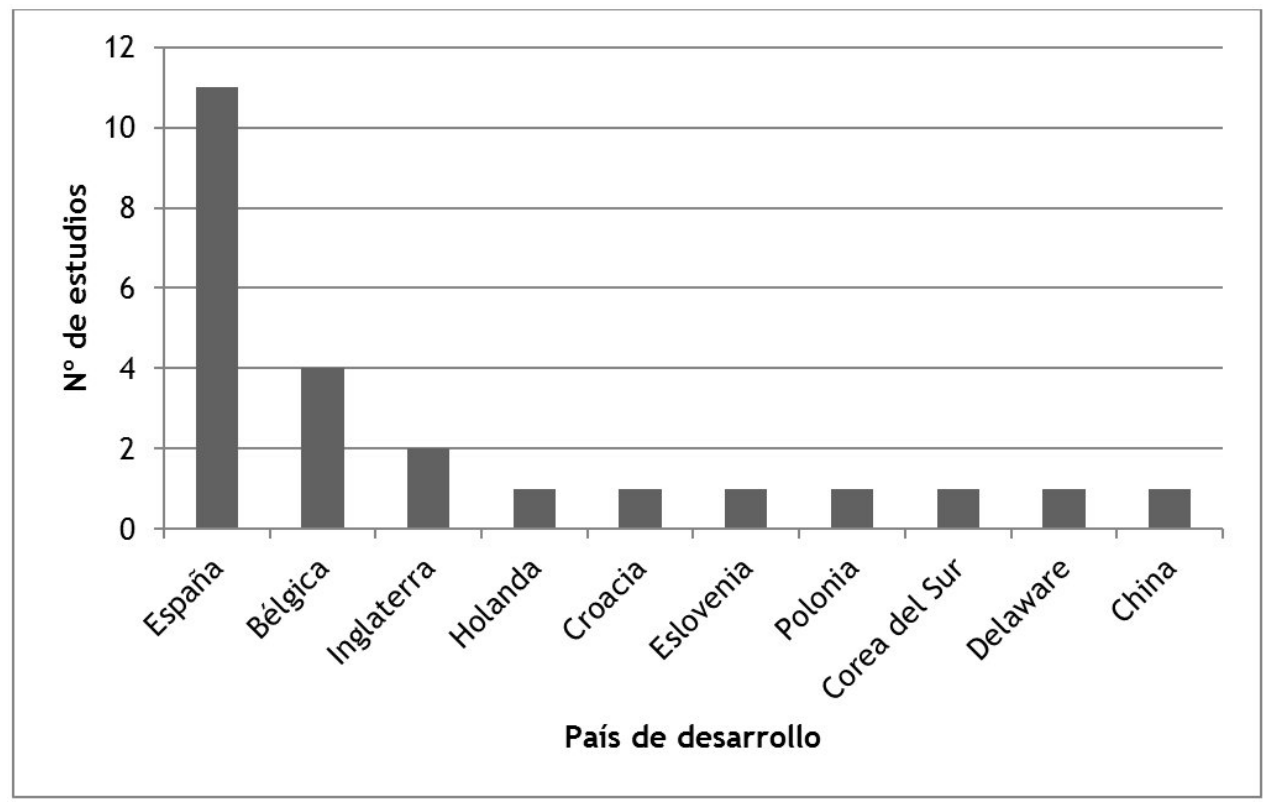

Figura 2.2. Distribución geográfica de los estudios finales.

Otra cuestión interesante es la distribución de la muestra atendiendo a su agrupación por el tipo de competencia más abarcadora (ver Figura 2.3). Cabe destacar que se han agrupado los estudios que tratan las competencias TIC y la 
mediática en el grupo de competencia digital, los que tratan la competencia ciudadana, social y cívica, emocional, emocional y social o emocional y atencional han pasado a formar parte del grupo de la competencia social y ciudadana, y el que aborda la competencia en alimentación se ha incorporado al grupo de la competencia científica.

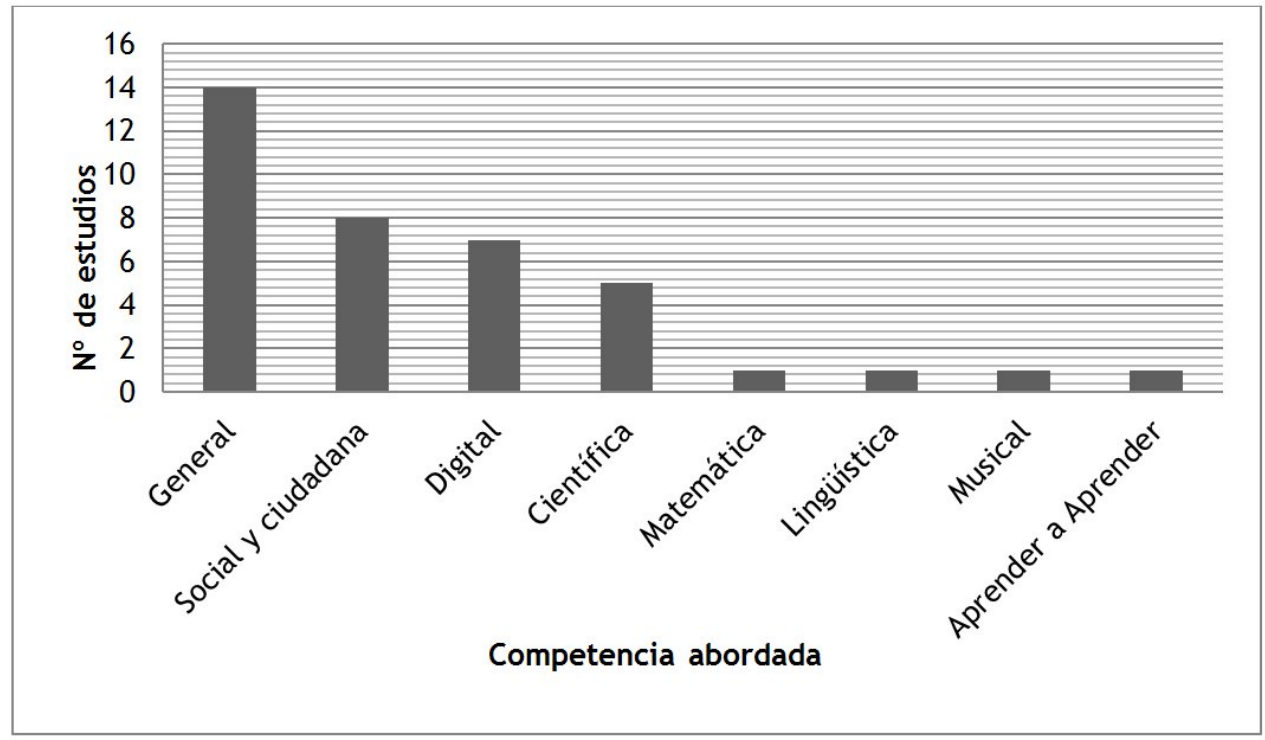

Figura 2.3. Distribución de los estudios finales agrupados por tipo de competencia abordada.

Aunque el marco competencial no se limita a los tipos de competencias expuestas en la Figura 2.3, la mayor parte de los artículos enfocan las competencias de una manera general y sin especificación $(n=14)$ o estudian la competencia social y ciudadana $(n=8)$. La competencia digital también adquiere una buena posición $(n=7)$, seguida de la científica $(n=5)$ y concluyendo con un único artículo para la competencia matemática, la lingüística, la musical y la competencia para aprender a aprender. Este panorama parece reflejar el auge de las Tecnologías de la Información y de la Comunicación (TIC) como integrantes de las competencias del siglo XXI (Almerich, Díaz-García, Cebrián-Cifuentes y Suárez-Rodríguez, 2018). También se manifiesta el importante papel otorgado a las competencias desde 
una visión general, como ocurre en España, por ejemplo, con las competencias clave.

Con respecto al tipo de artículo, sobre tres cuartos muestrales corresponden a estudios de corte empírico $(n=27)$ y alrededor de un cuarto a estudios teóricos $(n=11)$. Como se expone en el siguiente apartado, esta situación presenta repercusiones directas en la variedad dimensional abordada.

Para terminar con la descripción general, no existen grandes diferencias en cuanto al número de publicaciones por revista. No obstante, conviene indicar que la revista indizada en JCR de la que más artículos se seleccionaron es Computers \& Educaction $(n=5)$. Por otra parte, Investigación en la Escuela ( $n=$ $6)$ es la revista española incluida en RESH en la que más artículos se encontraron.

\subsubsection{Resultados de la revisión en profundidad}

Esta revisión se ha dedicado a estudiar tres cuestiones consideradas de especial relevancia para profundizar en la conceptualización del constructo de la competencia:

- Variedad de dimensiones competenciales estudiadas.

- Vertiente conceptual adoptada — según el marco teórico adoptado y el saber implícito que emana del estudio-.

- Presencia o ausencia de definiciones propias del concepto de competencia.

En la Tabla 2.3 se presenta una relación de los 38 estudios finales con la información correspondiente a cada parámetro revisado. 
Tabla 2.3. Datos de la revisión en profundidad de los 38 estudios finales

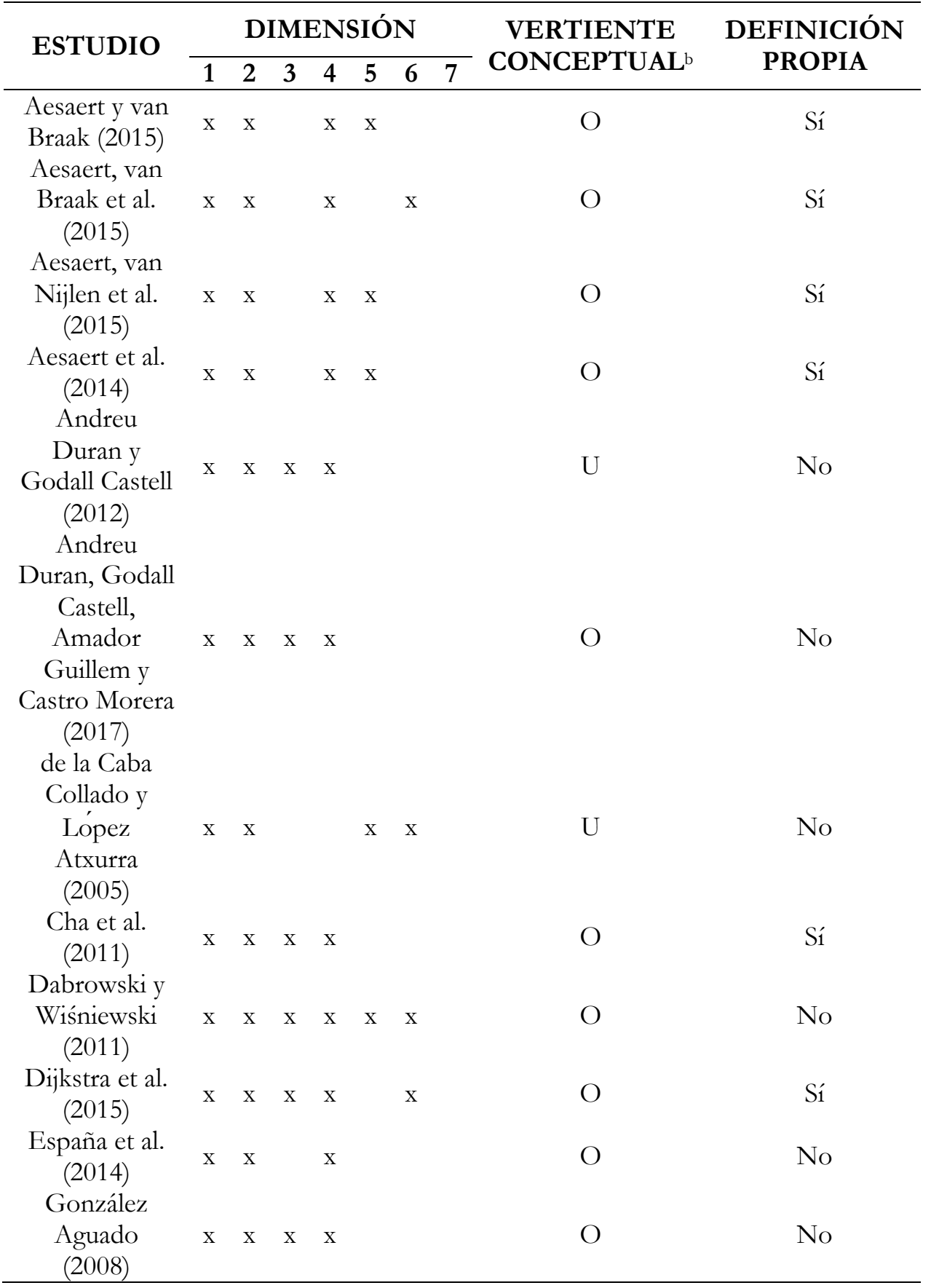




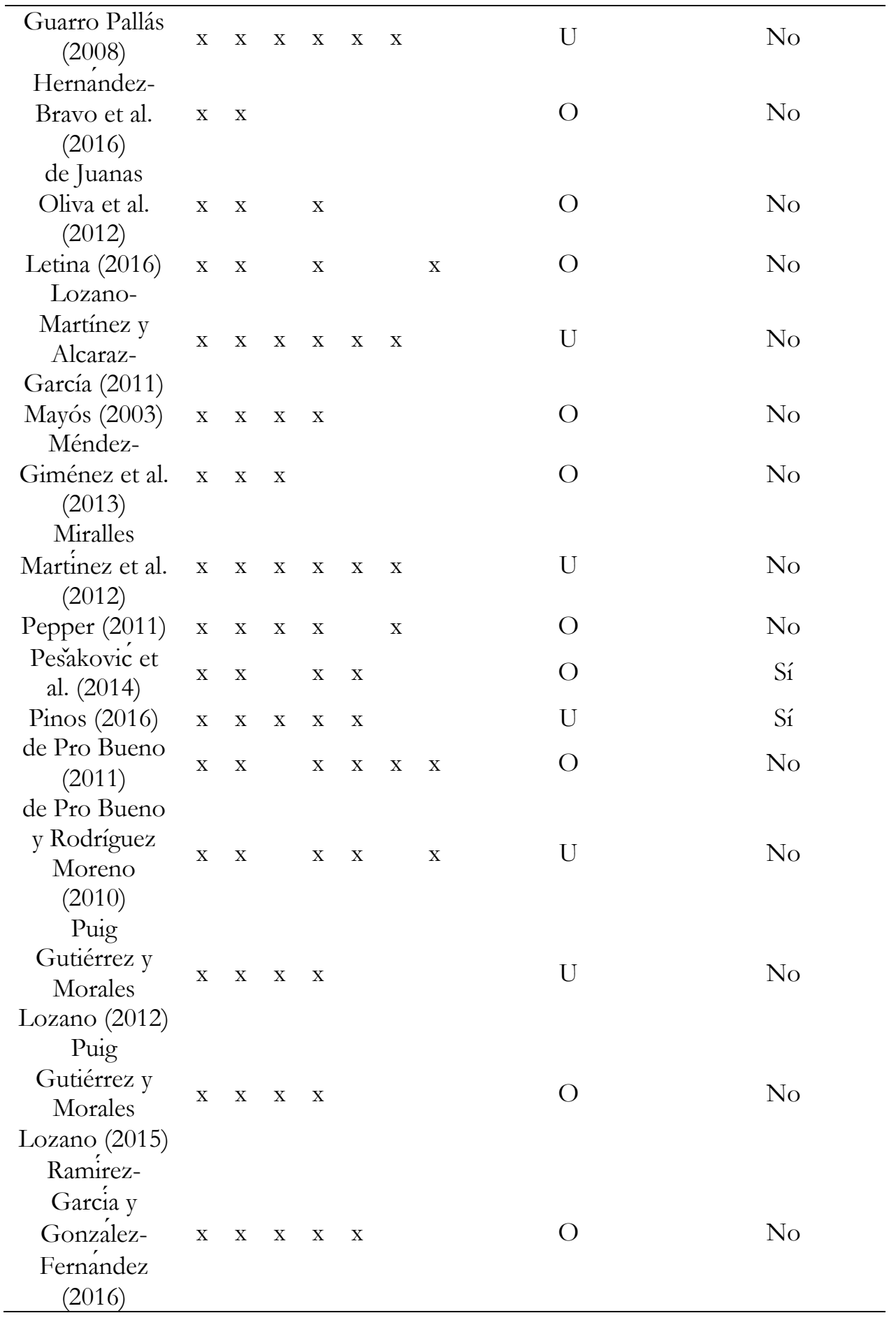




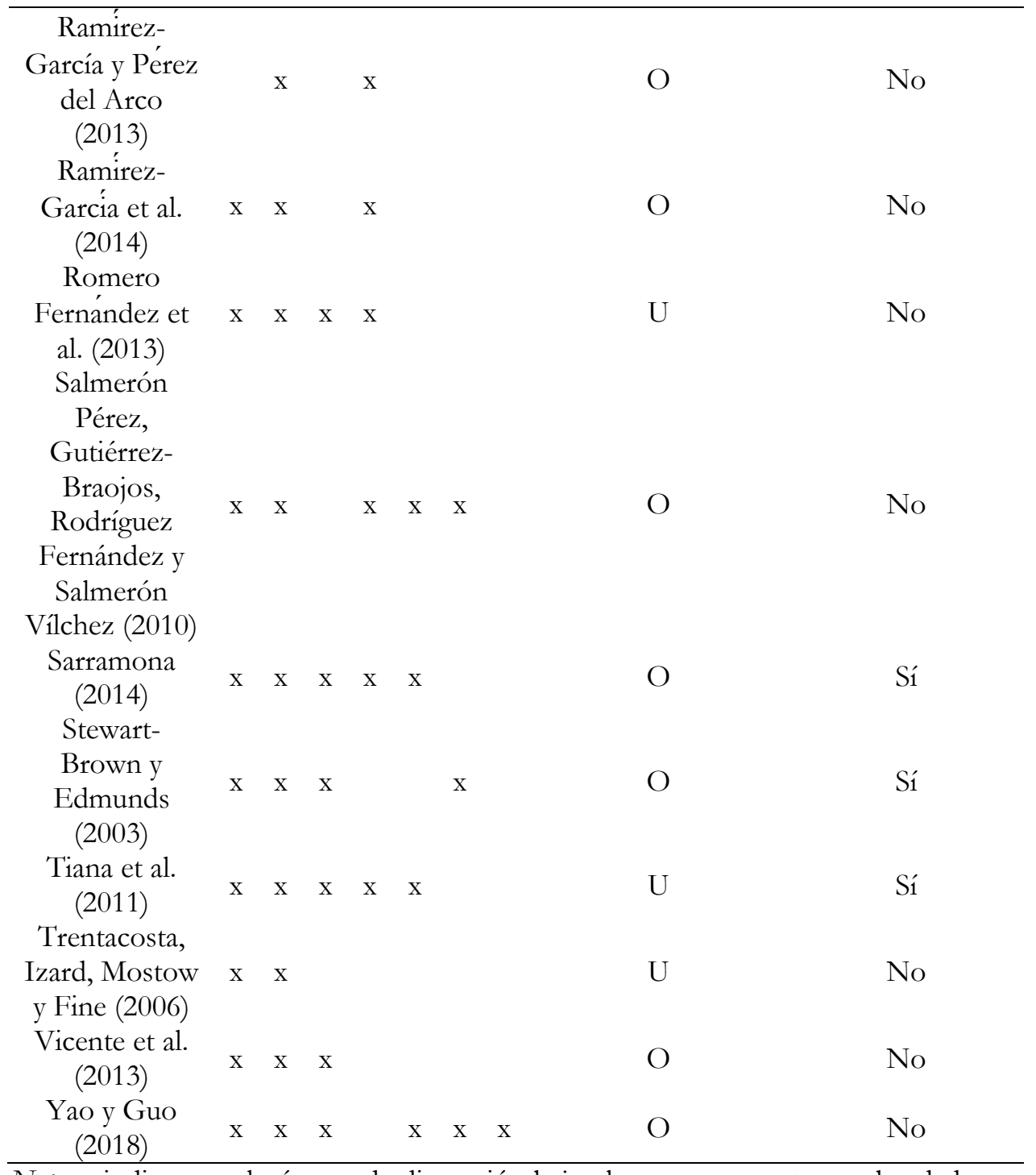

Nota. $\mathrm{x}$ indica que el número de dimensión bajo el que se encuentra es abordada por el estudio; $\mathrm{O}=$ Vertiente OCDE; $\mathrm{U}=$ Vertiente UNESCO.

Casi el total de los estudios $(n=37)$ aborda la primera dimensión competencial — un saber consciente y con sentido- y todos ellos abordan la segunda dimensión —un saber hacer eficaz cuyos niveles de eficiencia se pueden ir contrastando-, ya que su no tratamiento constituía un criterio de exclusión. Sin embargo, a medida que se incorporan nuevas dimensiones, 
menos son los estudios que las tratan. La tercera dimensión —un conjunto de actitudes y valores puestos en juego al intervenir en cada situación- es abordada por algo más de la mitad de los estudios de la muestra $(n=22)$, mientras que la cuarta —un contexto o escenario específico de la realidad del sujeto en el que la competencia adquiere significatividad- vuelve a suponer un conjunto significativamente amplio $(n=31)$. En cambio, al continuar con las dimensiones quinta — solvencia comunicativa—, sexta — consciencia- y séptima —naturaleza del conocimiento disciplinar-, mucho menos presentes en los marcos teóricos habituales, se experimenta una caída significativa de la porción muestral que las aborda. Concretamente, la quinta dimensión ya engloba un conjunto menor a la mitad de la muestra $(n=17)$ y la sexta menos de la tercera parte $(n=12)$. La séptima y última dimensión supone el número más reducido de estudios $(n=4)$. A juzgar por estos datos, los estudios se concentran en las dos primeras dimensiones y van dispersándose a medida que se incorpora el resto (ver Figura 2.4). Como información complementaria, se advierte que los artículos de corte teórico abordan de promedio un mayor número de dimensiones $(M=4.5)$ que los de índole empírica $(M=4.1)$.

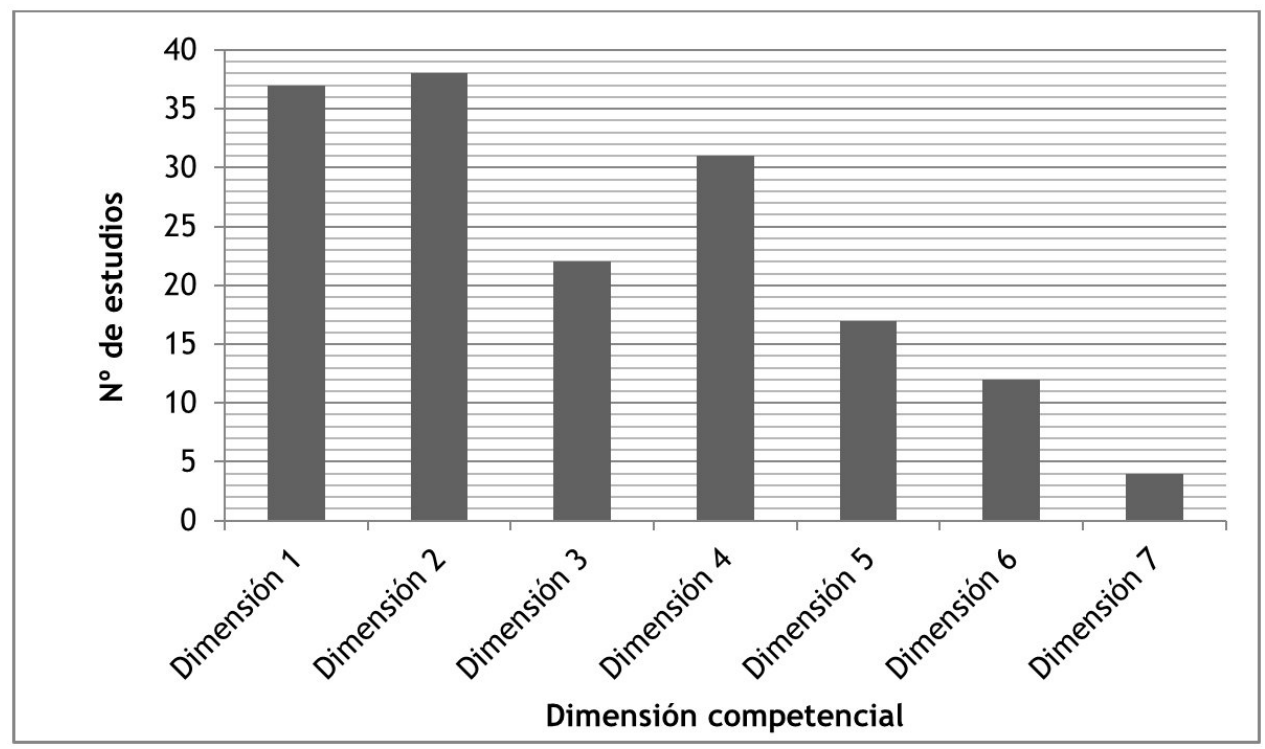

Figura 2.4. Distribución de la muestra atendiendo a las dimensiones competenciales abordadas. 
Con respecto a la vertiente conceptual adoptada, la mayoría de estudios $(n=27)$ adhiere a la visión proveniente del marco teórico propuesto por la OCDE, por ejemplo, en sus programas DeSeCo o PISA. Una minoría de la muestra $(n=11)$ adopta una visión fundamentada en el marco de la UNESCO, desde el Informe Delors hasta la agenda de la Educación 2030.

Por último, se ha detectado que alrededor de las tres cuartas partes de la muestra $(n=27)$ revelan una ausencia de definiciones propias del concepto de competencia, adoptando otras ya propuestas en estudios anteriores y siendo coherentes con el marco teórico adoptado. Además de las definiciones provenientes de los marcos teóricos de la OCDE y la UNESCO, abundan definiciones y elementos teóricos de otros autores como Zabala y Arnau (2007), en cuanto a cuestiones metodológicas y de evaluación; Perrenoud (1999) — - y todas las variantes de su obra—, en relación con la docencia; o Gordon et al. (2009), para referenciar el marco de las competencias clave y nuevamente el papel del docente. Estas adopciones suelen servir para ampliar el marco teórico de las investigaciones. Sin embargo, alrededor de la cuarta parte de los estudios $(n=11)$ corresponde a autores que proporcionan definiciones propias del concepto, aportando elementos relevantes y útiles en la conceptualización de la competencia. Por ejemplo, los estudios 1, 2, 3 y 4 del corpus aluden a un proceso de aprendizaje de orden superior y el 8 y 10 incluyen la visión holística de sociedad, cuestiones por lo general ausentes de los marcos teóricos más comunes.

\subsection{Discusión y conclusiones}

El objetivo que guiaba este estudio era revelar información rigurosa existente en la literatura para ayudar a elucidar la conceptualización de competencia y a comprender su significatividad en el sistema educativo actual, fundamentalmente en la etapa de Educación Primaria. Se han esbozado los marcos teóricos de la OCDE y de la UNESCO, los dos referentes de mayor importancia en la cimentación del constructo teórico competencial. Como primera conclusión se puede afirmar que resulta indispensable el conocimiento de ambos marcos para poseer una visión fundamentada y real de esta cuestión, noción que no parece estar cumpliéndose. 
Los resultados obtenidos de la revisión sistemática reportan un número escaso de estudios que abordan las competencias en la etapa de Educación Primaria; esta apreciación desvela un obstáculo para este estudio originado por la limitada información. En las dos primeras décadas del transcurso de las competencias por el entorno educativo apenas se realizaron investigaciones relacionadas con la Educación Primaria. Resulta comprensible que, desde la aparición en el ámbito laboral y su posterior enfoque a la evaluación educativa, se hayan requerido bastantes años para que el constructo haya permeado en esta etapa. No obstante, teniendo en cuenta los resultados de la distribución temporal de los estudios revisados y la importancia que sigue adquiriendo la educación basada en competencias desde temprana edad, se presencia una tendencia al alza. Así, es predecible la aparición de nuevos estudios sobre competencias que continúen ayudando a la comprensión de su significatividad en la Educación Primaria.

En relación con el panorama geográfico, no llama la atención que prácticamente la totalidad de estudios se desenvuelvan en países y revistas europeos, sobre todo teniendo en cuenta la influencia de las políticas de la Unión Europea en los sistemas educativos de sus Estados miembros y, por otra parte, el joven estado de maduración del constructo competencial a nivel de países no pertenecientes a esta asociación. En USA, Turquía, Taiwán, Canadá, China o Australia — países de los que más artículos se desecharon—, el estudio de las competencias todavía no parece haber cuajado, sino que se sigue manteniendo la visión más tradicional de las habilidades.

Otra conclusión es la necesidad de proponer más estudios direccionados a la especificidad de las competencias. Aunque se ha encontrado un buen número de trabajos dedicados a la generalidad competencial, la falta de investigación dirigida a las competencias específicas impide su desarrollo independiente y a su vez la construcción de herramientas de evaluación propias de cada competencia. Este problema se extiende tanto a la comunidad de investigadores como a la de maestros.

En el análisis en profundidad se ha registrado la variedad dimensional abordada en cada estudio, infiriéndose una visión reduccionista de las competencias. En concordancia, las definiciones utilizadas adoptan generalmente las dimensiones competenciales más clásicas — primera a cuarta - En este estudio se acuerda con la visión de Sanmartí Puig (2011) ya señalada y se comparte que el concepto de competencia supone - $-\mathrm{y}$ nosotros 
añadimos que ha de suponer- una evolución sustancial en la educación. Sin embargo, aún falta mucho trabajo para llegar a asumir su riqueza. En numerosas ocasiones parecen estar traduciéndose en términos de competencia operativa los antiguos objetivos conceptuales, procedimentales y actitudinales, visión restrictiva de cara al camino de una comprensión holística de lo que el enfoque competencial supone.

Los datos que arroja la revisión sistemática informan que los estudios de corte teórico proporcionan algo más de riqueza conceptual que los de índole empírica - los estudios empíricos no suelen profundizar en la teoría, sino que toman constructos ya elaborados-. Por ello, se advierte la necesidad de plantear más estudios teóricos, pues parecen ser los responsables del mayor avance en la conceptualización competencial, sin que esto signifique la reducción de la necesaria aplicación empírica.

Como se ha comprobado, la mayoría de estudios adhiere al marco teórico propuesto por la OCDE. Ante este escenario, se debe tener en cuenta que, de acuerdo con lo expuesto en el encuadre teórico, esta visión parece ser originariamente más profesionalizante y restrictiva — cuestión controversial presente - que la visión de la UNESCO, más encaminada a la educación integral de la persona. Sin embargo, en línea con de Pro Bueno (2011) «creemos que lo importante no es tanto con qué intención se introdujo sino cómo se concreta en las aulas y en los centros» (p. 7). Por ello, desde este estudio se considera que ambos marcos teóricos implican idéntica inclusión en la etapa de Educación Primaria, suponiendo un cambio colosal en la concepción educativa. Desde esta óptica se ha de aprovechar la operatividad que la fusión de ambos marcos ofrece. Sin embargo, se desconoce la validez de esta reflexión para etapas posteriores.

En resumen, la educación basada en competencias ha implicado un cambio profundo en la forma de entender la educación, lo que debería conllevar necesariamente un cambio metodológico, bajo nuestro punto de vista más encaminado a propuestas multi, inter y transdisciplinarias. Aunque es evidente su papel evolutivo, todavía se encuentra en la literatura una visión poco meditada del constructo, adoptándose y repitiéndose ideas construidas. Con esta reflexión no se pretende desalentar a la comunidad educativa, sino poner en conocimiento una situación real e instar al esfuerzo de todo el sistema educativo para obtener el máximo provecho que brinda la educación basada en competencias. 
Nuestro trabajo pretende contribuir a clarificar el concepto de competencia y a proporcionar una visión profunda de su investigación en la Educación Primaria, con la fortaleza de ofrecer una fundamentación teórica robusta sobre la que otros estudios pueden apoyarse y profundizar. Una limitación de este trabajo, que sería interesante atender en futuros estudios, es la ampliación de la revisión sistemática incluyendo revistas de justificada calidad de otros países, tal y como se realizó aquí con España; esta acción podría contribuir a ampliar los conocimientos sobre el concepto de competencia. 



\section{CAPÍTULO 3}

Un encuadre teórico para la educación STEM/STEAM integrada 

$\mathrm{P}$ ara continuar con la fundamentación teórica de esta investigación, este capítulo se ha dirigido a determinar los fundamentos teóricos de la educación STEM/STEAM integrada. En primer lugar, se estudian las características de la educación STEM/STEAM integrada y sus potencialidades para el desarrollo competencial en la Educación Primaria. Después, se construye un encuadre teórico para este enfoque empleando el modelo reticular propuesto por Larry Laudan y fundamentado desde la epistemología, la psicología y la didáctica que contempla los diversos aspectos que implica el término competencia y que se enfoca a potenciar su desarrollo integral en la Educación Primaria.

Este capítulo se corresponde con el artículo de investigación que lleva por título en inglés «A theoretical framework for integrated STEM and STEAM education», que actualmente se encuentra en proceso de revisión. Por ello, se ha considerado adecuado presentarlo manteniendo la estructura del propio artículo. Solamente se han omitido las referencias bibliográficas, que se presentan compiladas en el Capítulo 9.

\subsection{Abstract}

For several decades there has been a broad consensus on the need to promote scientific literacy and, ultimately, to promote a broad competency development from an early age. However, many of the results recorded in the educational field are not very encouraging. Although interdisciplinarity has a much broader trajectory, the continuous questioning of traditional teaching methods due to their inefficiency has given rise to the emergence of educational approaches that integrate the teaching of diverse scientific disciplines in a more contextualized, coherent, and comprehensive manner. The body of empirical research on the application of these approaches has grown while leaving some essential theoretical questions behind. In the present work, a theoretical framework is proposed for integrated science, technology, engineering, and math (STEM) and integrated science, technology, engineering, arts, and math (STEAM) education, which are two of the current teaching approaches with more increasing momentum. Based on the epistemological stance of Larry Laudan, three levels of scientific commitment are adopted: with theories, with methods, and with the aims. At the theoretical commitment, three axes of 
support are established for this framework: epistemological, psychological, and didactical. This mechanism allows us to construct a consistent model that may contribute to developing integrated STEM and STEAM education with a greater commitment to the theoretical foundations of science education.

\subsection{Introduction}

In the last decades of research in the field of science education, two topics continue to appear in many international articles and research reports. First is the concern over the indispensable nature of scientific literacy for citizens to exercise their full rights (EC, 2015; NGSS Lead States, 2013). Second is the concern of many governments and organizations regarding the decrease in the number of young people choosing to study scientific-technological disciplines at the end of their compulsory schooling (DeWitt \& Archer, 2015; NRC, 2012, 2014). Consistent with this topic, Kezar, Gehrke, and Bernstein-Sierra (2017) have affirmed that «for the past 20 years, countless reports have been issued calling for reform of undergraduate education to improve student learning, persistence, and graduation rates for students in science, technology, engineering, and mathematics (STEM) majors» (p. 217). If undergraduate education has to be reformed, K-12 education has also to be transformed (NRC, 2012).

Based on this situation, some interdisciplinary approaches have emerged in the field of science education, although the number of "data driven" research reports or of theoretical foundations are small (Gresnigt, Taconis, van Keulen, Gravemeijer, \& Baartman, 2014).

Although approaching the conceptualization of interdisciplinarity historically can lead to philosophers such as Plato, this concept has been shaped in the last century by many thinkers who have alluded to interdisciplinarity in education. For example, the American philosopher, pedagogue, and psychologist John Dewey (1929) established that the science of education was comprised of a series of disciplines responsible for studying different aspects of education scientifically, a complex phenomenon occurring in all areas of society. Austrian-British philosopher Karl Raimund Popper (1963) commented that we are not students of subjects or disciplines but of problems that can cross disciplinary boundaries. 
For the sake of clarity, we will define our use of the term interdisciplinarity as well as others such as multidisciplinary and transdisciplinary. From a very broad epistemological perspective, the multidisciplinary level occurs when information is obtained from two or more disciplines to solve a problem without modifying those disciplines. At the interdisciplinary level, several disciplines cooperate, producing enriched interaction. The transdisciplinary level encompasses the interdisciplinary and eliminates the boundaries between the disciplines (Piaget, 1972). The superior level represents a complete system in which the disciplinary interaction is such that a new macrodiscipline appears (Torres Santomé, 1994).

Within the framework of interdisciplinarity, and given the continuous criticism of traditional teaching as a simplistic reductionist approach addressing the disciplines in isolation (Connor, Karmokar, \& Whittington, 2015), an interdisciplinary educational approach developed that was labelled with the acronym STEM, advocating the literacy of people in the four disciplines (Bybee, 2013).

An effective STEM education must capitalize on students' interests and early experiences, build new knowledge on what they already know, and provide experiences that involve and arouse their interest in scientific practices (NRC, 2011). However, the literature contains variations on the meaning of a STEM education (Breiner, Harkness, Johnson, \& Koehler, 2012). Among a wide range of conceptions, Ritz and Fan (2015) found three latent interpretations. Most of the proposals seem to be concentrated on the renewal of the teaching of each discipline separately (Bybee, 2013). Meanwhile, another interpretation advocates conceiving of STEM education as an approach integrating the different scientific disciplines. In this context, the disciplines are intentionally integrated through the resolution of genuine problems, those belonging to the real world, a concept underlying recent European recommendations (EC, 2015) and that have appeared in the United States for much longer. A third interpretation combines both approaches.

From our perspective, STEM education implies a higher level of integration than the treatment of the four literacy branches defined separately. We consider, as Zollman (2012), STEM as a new discipline uniting all of them in what has been called integrated STEM education (NRC, 2014). 
Given the educational projection of this approach, many empirical studies regarding its practical application has been accumulating in recent years, especially in the field of science education (Brown, 2012; Mizell \& Brown, 2016). However, some essential theoretical questions have been forgotten; above all, a theoretical framework to understand integrated STEM education is lacking (NRC, 2014). Theoretical studies and reflections from philosophy are necessary, since they offer a better conceptual understanding of the scope and constraints of empirical investigations (Gil Cantero \& Reyero, 2014). In this regard, some significant contributions have been made, mostly focused on methodological approaches (Association of American Universities [AAU], 2011; Kelley \& Knowles, 2016; NRC, 2011, 2014; Quigley, Herro, \& Jamil, 2017). However, these studies have not delved excessively into the psychological view or into coherence with epistemological foundations, which are issues that have already manifested (Zeidler, 2016). Thus, the development of a more holistic theoretical foundation, especially from an epistemological view that supports integrated STEAM education and its predecessor STEM, is still not found in the literature. Likewise, its aims must be established, which undoubtedly influence the adoption of epistemological, psychological, and didactic positions. Hence, the objective of this position paper is to propose a theoretical framework for both approaches, integrated STEM and STEAM education, steering them towards competency development of the students and bringing these approaches closer to a more formative and humanistic position, essential in scientific education (Zeidler, 2016; Zeidler \& Sadler, 2007). In addition, by proposing this framework, we intend to place these approaches in the educational landscape within the theoretical foundations of science education. Although this theoretical framework is valid for the two approaches, in this paper, the term integrated STEM education will be used since it is more commonly known in the literature.

\subsection{Some crucial issues about STEM and STEAM education}

Many definitions and proposals of STEM education suggest positions close to professionalization and coverage of economic needs (Breiner et al., 2012; Bybee, 2013; Herschbach, 2011; Zollman, 2012). In this sense, several criticisms have been advanced, especially with regard to the sociopolitical silence that is apparent in a lot of STEM policy (Chesky \& Wolfmeyer, 2015; 
Gough, 2015), that makes it "unlikely [that] students will engage in criticism of STEM processes and practices that support economic growth, and instead will orient students to support them" (Hoeg \& Bencze, 2017, p. 857). Among others, Zeidler (2016) considered that if STEM education is not reframed within broader sociocultural and political frameworks, then the educational model of STEM initiatives will be deficient.

We agree with these critical views, and so, in line with Zollman (2012), we believe that, in the educational field, integrated STEM education should aim at developing an integrated education and continuous learning, aiming for a higher level of competency development for all citizens from a humanist perspective (UNESCO, 2016). So, although emphasizing the need for education to have practical applications, we consider that is relevant to maintain the ideals of an education that provides citizens with the tools to live in society and to contribute to it, based on the four pillars of education: knowledge, comprehension, competencies for life, and competencies for action (Delors, 1996). That is, in our understanding, integrated STEM education, instead of prioritizing employment after the completion of school, should engage students in more active and participatory community-grounded science, inclusive of calls for social justice and citizenship (Calabrese Barton, 2012). We believe that scientific vocations will emerge naturally from this development of humanistic competency, a question that has previously been discussed elsewhere (Maltese \& Tai, 2010). Thus, given the complex and comprehensive nature of the competency construct and its multiple dimensions - a meaningful knowledge; an effective and transformative know-how; a set of attitudes and values; a specific meaningful context; communicative solvency; awareness and understanding of what is done; and a sophisticated epistemic view - the use of integrated STEM education appears to be an appropriate and beneficial approach for that purpose (Ortiz-Revilla, Greca, \& Adúriz-Bravo, 2018d).

Although there are different perspectives on the integration of STEM, most of the proposals have focused on the study of science and mathematics (Breiner et al., 2012; Bybee, 2013; Hoachlander \& Yanofsky, 2011; Kelley \& Knowles, 2016; Sanders, 2008). This focus has caused research in this area to be less mature and often ambiguous when examining the integration of technology and engineering (Bybee, 2010; Herschbach, 2011; Hoachlander \& Yanofsky, 2011; Kelley \& Knowles, 2016) given that these subjects are not 
usually present in the early stages of compulsory education (NRC, 2011). In addition, with the aim of expanding the connections students can make between the disciplines (Land, 2013; Quigley \& Herro, 2016) and reinforcing learning, more balanced teaching-learning approaches have been proposed including arts, design, and humanities in STEM education (Connor et al., 2015).

In recent years, numerous studies have incorporated arts into STEM education with the aim of motivating secondary school students to subsequently study science and mathematics (Kim \& Bolger, 2017; Quigley \& Herro, 2016). However, in line with Land (2013), we consider that integrating arts into an already integrated STEM education should go beyond preparing students for subsequent study, helping to foster creativity, innovative spirit and critical thinking often absent in education systems. In the same way, the introduction of arts reinforces the development of digital competency and the knowledge of engineering design (Chien \& Chu, 2018; Roehrig, Moore, Wang, \& Park, 2012), both of which are of great didactic interest in the early educational stages. Nevertheless, perhaps the most important point is that the Arts implies the inclusion of important areas that inform and contextualize science by grounding them in sociocultural contexts, such as sociology, psychology, history, fine arts, and philosophy (Zeidler, 2016).

Integrated STEAM education has been broadly defined as a transdisciplinary approach aimed at solving genuine problems. According to Quiley and Herro (2016) "the goal of this approach is to prepare students to solve the world's pressing issues through innovation, creativity, critical thinking, effective communication, collaboration, and ultimately new knowledge" (p. 410). Therefore, given that multidisciplinary approaches are not usually focused on problems, STEAM education prefers interdisciplinary and transdisciplinary approaches, which have an iterative process of creating new questions from different disciplines (Quigley \& Herro, 2016). These two levels represented the higher stages of integration from the pioneering and popular hierarchies proposed for the levels of collaboration and integration between disciplines (Jantsch, 1972; Piaget, 1972), in which multidisciplinarity ranked as either the lowest or lower than integration and coordination (Gresnigt et al., 2014). In short, the inclusion of arts offers a natural and broader platform for transdisciplinary inquiry (Quigley \& Herro, 2016), and opens the door for sociocultural integration (Zeidler, 2016). In this position paper, integrated STEAM education and its STEM predecessor are understood as crosscutting 
educational instruction allowing students an integrated and humanist development of competencies.

\subsection{Structure of the theoretical framework}

Duschl (1990) stated that adopting a curricular perspective that evolves from a complex set of scientific processes based on epistemological principles allows the possibility of integrating a broader range of curricular approaches in the stages of primary and secondary education. Thus, the present construction of the theoretical framework for integrated STEM education is based on the epistemological position of the American philosopher of science Larry Laudan.

Although Laudan assumes no single theory of scientific change exists, he proposes, from his pragmatic and rational view, a series of criteria that operationalize the construction of a normatively viable philosophy of science. Within the metamethodology created by Laudan (1977), scientific progress is determined by the number of problems a theory is capable of solving. It is defined around the effectiveness of a theory in terms of solving problems. From this perspective, science represents a permanent activity of problem solving, and the rule guiding scientific progress is the coexistence of different research traditions. The comparison between theories leads to a rational and progressive change in which there is no cumulative conservation. Theoretical gains and losses coexist based on the effectiveness in solving scientific problems. Thus, problems represent the central point of scientific thought, constituting scientific inquiries, the challenging questions that generate the need for resolution in the scientific community. Laudan distinguishes between two types of scientific problems: empirical —any aspect of the natural world that surprises us as strange or that requires an explanation, that is, substantive questions about the facts constituting the domain of any science- and conceptual -deficiencies or internal inconsistencies of the theories, that is, problems, conflicts, or controversial aspects presented within a theory or a theoretical framework-.

From Laudan's philosophy of science, a theory - or a scientific response - solves an empirical or a first-order problem when it - together with constraints - explains, clarifies, and answers the problem. A theory solves or eliminates a conceptual or higher order problem when it overcomes the 
conceptual difficulties or theoretical conflicts of its predecessor theories or when it presents no conceptual difficulties. Thus, a theory is more progressive when it explains more empirical relationships and obviates more conceptual problems. Based on Duschl (1990), progressive theories are those most closely approaching or entering the core of the research programs of Lakatos (1970).

To address rational and regulated scientific progress, Laudan proposes his Reticular Problem Solving Model. The reticular model acquired this name because of his opposition to the hierarchical model commonly used and accepted by the philosophers of science, such as Kuhn (1962), in the first half of the twentieth century. This hierarchical model assumes that factual/theoretical disputes are resolved by appealing to methodological principles and methodological disputes are solved when related to the objectives that science establishes. That is, hierarchical models emphasize theory-related commitments over and above the other two. In Laudan's view, theoretical assumptions, methodological principles and research aims are interrelated, and scientific change is more gradual and less holistic that the one proposed by Kuhn, in which an older paradigm — with its theories, methods and aims - is replaced in whole or in part by an incompatible new one.

Within this framework, Laudan (1984) presents the Triadic Network of justification. This model postulates an epistemological analysis of scientific development composed of three levels of scientific commitment with the same status that interact complexly and whose modifications are not always simultaneous ${ }^{2}$ : commitment with theories, with methods, and with the aims. There is a strong interrelation between these three levels of scientific commitment:

- The methods justify the theories.

- Theories limit the methods, restricting the methodologies to be used.

- The aims, objectives, or goals justify the methods; they indicate the choice of methodologies to be used.

- The methods clarify the feasibility of the aims, objectives, or goals; they demonstrate their viability.

- Theories must harmonize with the aims, objectives, or goals.

\footnotetext{
2 Some examples based on historical scientific events can be found in chapter four, Dissecting the holistic picture of scientific change, of Laudan's book (1984).
} 
These three levels of commitment are postulated by Laudan for any contribution to the construction of scientific knowledge and as participants in a complex process of adjustment and mutual justification. As a result, a decision with respect to one element can be motivated from a position with respect to another element. According to Laudan, (1984) the elements of this model imply "that our factual beliefs drastically shape our views about which sorts of methods are viable, and about which sorts of methods do in fact promote which sorts of aims" (p. 62). Decisions on scientific aims, methods and theories become an exercise in empirical comparison, rather than a matter of adherence to conventions. We adopt these levels in the present theoretical framework (Figure 3.1) for the composition of a cohesive and coherent model that supports integrated STEM education.

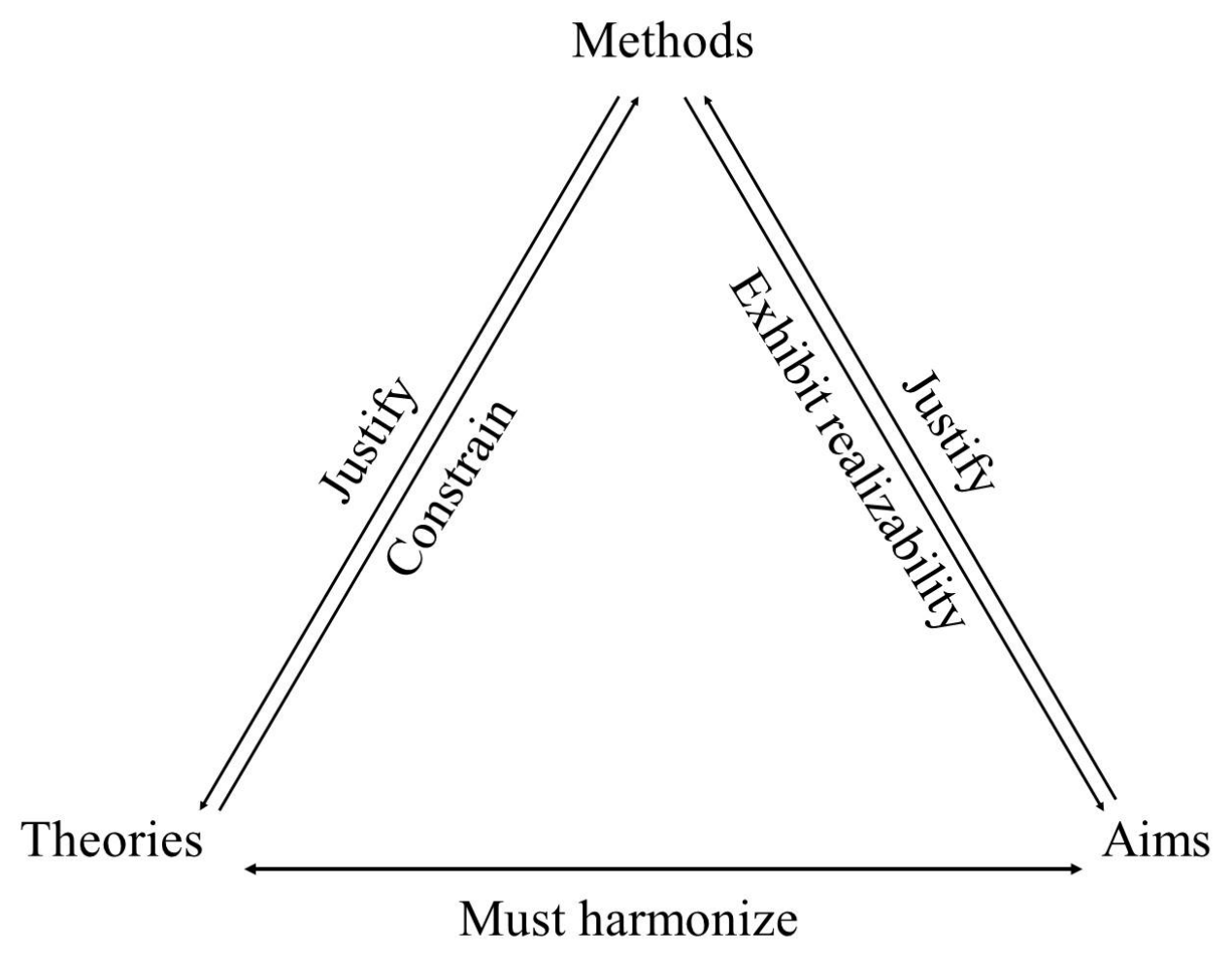

Figure 3.1. General scheme of the Triadic Network. From Laudan (1984). 
We consider that this model is acceptable, so that integrated STEM education can be presented with greater clearly, because it demands express statements of aims, theoretical assumptions, and methodological approaches -in fact, that last point is the main aspect addressed in much of the STEM research literature —, which must be coherently interrelated, prompting a healthy discussion focused on all the elements involved in both teaching and learning.

In the next section, we present our own selection of methods, theories and aims for integrated STEM education.

\subsection{The triadic network for integrated STEM education}

As indicated, in this paper integrated STEM education is understood as a possible channel for integrated competency development. Therefore, within the triadic network for integrated STEM education, the goal consists of improving the competency development of the students, specifying an appropriate methodology that makes this goal possible. If, as has been pointed out, the traditional methodology is not effective for improving competency, a different approach must be taken. Consistent with the view that science represents a permanent problem-solving activity and with the adopted definition of STEM, research is used as the main didactic methodology, largely in line with the interest in competency development (Aguilera Morales et al., 2018). Inquiry, inquiry-based science education (IBSE) and inquiry-based learning (IBL) have been defined as ways to teach and learn science, implying that students observe; raise questions; seek information; plan research; review existing knowledge in the light of experimental evidence; use tools to collect, analyse and interpret data; propose answers, explanations, and predictions; and communicate results (NRC, 2000). Of special interest for the aims that are addressed is the use of socio-scientific inquiry-based learning (SSIBL), where the integration of citizenship education, socio-scientific issues (SSI), and IBSE provides a model for both using and building scientific knowledge, to enable change by asking authentic questions; conducting IBL and taking action (Levinson, 2018).

Although there are many recommendations about the use of inquiry and manifestations in terms of its general effectiveness in teaching science 
(Bevins \& Price, 2016; NGSS Lead States, 2013), in this framework, guided inquiry —in any of its versions - is used (Bevins \& Price, 2016; NRC, 2000) because it is the model that seems to provide the best learning results (Minner, Levy, \& Century, 2010). This adoption does not nullify the possibility of using other methodologies provided these allow to make the desired goal viable, such as Project Based Learning (PBL) (Capraro, Capraro, \& Morgan, 2013) or the engineering design process (NRC, 2009). In this way, the repeated insistence on the use of certain methodologies for the integrated STEM approach (EC, 2015; NRC, 2011, 2014) is justified by the aim pursued.

Finally, the theoretical level is incorporated into the network, whose constructs have been based on three compatible axes: epistemological, psychological, and didactical. The articulation and interrelation of these three axes, previously considered for the production of knowledge in the field of science teaching (Arriassecq, Greca, \& Cayul, 2017; Artigue, 1988; Buty, Tiberghien, \& Le Maréchal, 2004), completes a coherent and consistent model that fits our main objective. Just as not any methodology guarantees the viability of integrated STEM education, neither is any set of theories consistent with the methodology used. Within the epistemological axis, essential for the understanding of the principles, foundations, and scientific methods, Laudan's position has been adopted. The theory of conceptual fields of the French psychologist, Gérard Vergnaud, constitutes the psychological axis that offers a means of interpreting the way in which the students conceptualize. Although the previous theoretical constructs have important didactic consequences, a specific didactical axis must be adopted to support the teaching process, considering the didactic transposition (Chevallard, 1985). In proposing the didactical axis, the position of the French didactic researcher Jean-Louis Martinand has been considered, specifically his objective-obstacle notion. This set of theories, which will be described below, restricts the adoptable methodologies, as will be seen in the next subsections.

Once the theoretical level established for the triadic network of integrated STEM education is described, it should be made explicit that, just as the theory of the epistemological axis has been justified by the adopted methodology, the constructs of the psychological and didactical axes, in addition to being compatible and consistent with the epistemological axis, must be harmonized with the aim; this effort is required since the objective-obstacle notion appears necessary to explain competency development (Perrenoud, 
1997, 1999), and the theory of conceptual fields allows some aspects to be qualified, such as the long-term stability of the competency (Perrenoud, 1997).

Figure 3.2 shows the triadic functioning model created for integrated STEM education, indicating the location of the three presented axes, with a detailed explanation. Note the importance of the complex process of adjustment and mutual justification of the three levels of commitment.

\section{METHODS \\ IBL, SSIBL and/or other related methodologies}

\section{THEORIES}

- Epistemological axis (Laudan, 1977)

- Psychological axis (Vergnaud,1990)

- Didactical axis (Martinand, 1986)

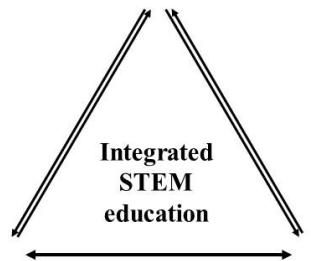
competence development

Figure 3.2. Model of triadic functioning for the theoretical framework of integrated STEM education.

Through this framework, a more holistic perspective of science education is provided since it establishes a reasonable balance between the two main research approaches traditionally adopted in this area: the orientation towards science and the orientation towards students (Duit, 2006). This perspective has already been shared by several researchers in the area (Dahncke et al., 2001; Duit, 2006; Duit, Gropengießer, \& Kattmann, 2005; Fensham, 2001; Méheut \& Psillos, 2004; Psillos, 2001). 


\subsubsection{Epistemological axis}

In addition to the fact that Laudan's problem-solving model (1984) provides a way of combining the different levels of scientific commitment as discussed above, another intrinsic aspect of his philosophy occurs within the theoretical level. His notion of scientific progress and his conception of the problem constitute a fundamental construct for integrated STEM education. The relationship is obvious between Laudan's notion (1977) of scientific progress, the resolution of a larger number of problems, and the conception adopted here about the teaching-learning process from the approach of integrated STEM education, whose nature is also the resolution of problems. In particular, those problems related to science present in the daily life of students and requiring an explanation Laudan conceives as empirical problems. Thus, within this theoretical framework, a problem is understood as a variety of situations, issues, tasks, designs, creations, assemblies, projects, activities, challenges, etc., that are real and relevant and that demand explanations and/or solutions developed from the integration of STEM disciplines. Situations that are both real and relevant will help to achieve the proposed aims, so that students can acquire the tools to live in society and to contribute to it; in particular, situations that relate to contemporary global issues. As discussed in Duschl (1990), although it cannot be treated as a complete model in itself, this epistemological approach can guide the selection and sequence of scientific concepts to be addressed in the classroom; it can guide the teaching and learning of science.

Because the previous section touches upon this concept, the explanation of this epistemological theory will not be expanded upon. However, from this perspective, the student's progress in the acquisition of competencies in all their dimensional complexity (Ortiz-Revilla et al., 2018d) can be inferred from the number of real problems that he or she is capable of solving, the very essence of competency development. This perspective moves away from a purely technical resolution of the problems posed.

\subsubsection{Psychological axis}

Vergnaud's theory of conceptual fields is framed within cognitive psychology and designates cognition as a basic ingredient for conceptualization (Vergnaud, 
1990, 1998, 2013). For Vergnaud (1990), all knowledge — how to do and how to express what is done- is divided into conceptual fields whose domains can take a long time to be apprehended. From this perspective, Vergnaud (1982) defined the conceptual field as a large informal and heterogeneous set of problems, situations, concepts, relationships, structures, contents, and operations of thought connected and probably interwoven during the acquisition process. In this theory, a concept is composed of Situations, Operational invariants and Representations (S, I, R).

To achieve conceptualization or the domain of a conceptual field, an individual must face a large number and variety of situations $(\mathrm{S})$ demanding their performance. In this way, situations constitute the concept's reference. To deal with such situations, the individual handles a whole set of ideas, mostly implicit, which Vergnaud calls operational invariants. Operational invariants (I) are composed of concepts in action - relevant or irrelevant primary ideas on which learning is built, in the sense of Ausubel's famous subsuming concept (Ausubel, 1968), and theorems in action - true or false proposals about such concepts. A dialectical relationship exists between the concepts and the theorems in action; the concepts are ingredients of the theorems, and these are the properties giving the concepts their contents (Greca \& Pereira de Ataíde, 2019). Therefore, operational invariants are formed largely through experience and offer incontestable contributions to the development of an individual (Vergnaud, 2007), constituting the meaning of the concept. Finally, operational invariants occur within the schemas, more stable cognitive structures belonging to long-term memory. Specifically, a scheme is the invariant organization of an individual's behaviour in various situations, so, as the schemes are used and verified in situations, there is a balancing effect of cognitive structures through Piagetian assimilation, adaptation, and accommodation (Piaget, 1936). With the exception of its generic concept of adaptation to the environment, the scheme specifically adapts to the situation (Vergnaud, 1996) ${ }^{3}$.

\footnotetext{
${ }^{3}$ For example, for solving problems in kinematics, students may have a scheme in which there are some concepts-in-action related to speed, distance, time, that at the same time are the "objects" the student will see in the situation. Also, the scheme has to include some theoremsin-action - generally rules for solving these kinds of problems and also formulas-. If the students identify that a problem is a "kinematic" problem, they will apply this scheme. But, students will not apply the same scheme, if identifying the problem as belonging to another class of situation that is not "kinematic". That difference can explain why students very often fail to use a similar "process" to solve problems that are, from the point of view of physics,
} 
Thus, for conceptualization to occur, teaching must manage students' operational invariants in a variety of situations that, in the case of approaching problems from integrated STEM education via the adopted methodology, arise naturally (Kelley \& Knowles, 2016). Although the operational invariants generally assume implicit knowledge, a small fraction usually manifests itself explicitly. At this moment, the teacher must infer the distance at which the operational invariants students are handling sit from the real and expected scientific knowledge in education. Thus, the teacher is responsible for stimulating, creating, or inducing situations through social interaction (Vygotsky, 1962) triggering a cognitive destabilization of students, remembering that such situations must be in their Zone of Proximal Development (Vygotsky, 1978), which has been considered as the most difficult task for the teacher (Vergnaud, 1998). However, in the case of integrated STEM education made viable through inquiry-based methodologies, the intrinsic group work, the multiple experimental situations, and the natural emergence of genuine problems are beneficial for enhancing social interaction and situations of cognitive imbalance.

Also necessary are the representations $(\mathrm{R})$ or symbolism that the individual adopts in the process of conceptualization. These are explicit and symbolic manifestations and compose the meaning of the concept. Students' representations, therefore, constitute an important source that the teacher can take advantage of to understand the way students operate. However, frequently, and particularly in science and mathematics, students have different representations for the same concept — definitions, formulas, algebraic representations, graphs, drawings, etc. - and to master a conceptual field the subject must be able to use these different representations in a coordinated manner. In the case of inquiry-based methodologies or other related methods such as PBL or engineering design, the fact that students have to draw, design, discuss, plan, materialize, collect data, express themselves, make presentations, build, etc., assiduously implies the use of different representations that favor acquisition of the conceptual field.

Figure 3.3 shows the workings of the ideas presented in this theoretical construct when explaining the conceptualization process of students.

identical, for example a block in free fall, blocks connected by a rope, blocks on a ramp (Greca \& Pereira de Ataíde, 2019). 


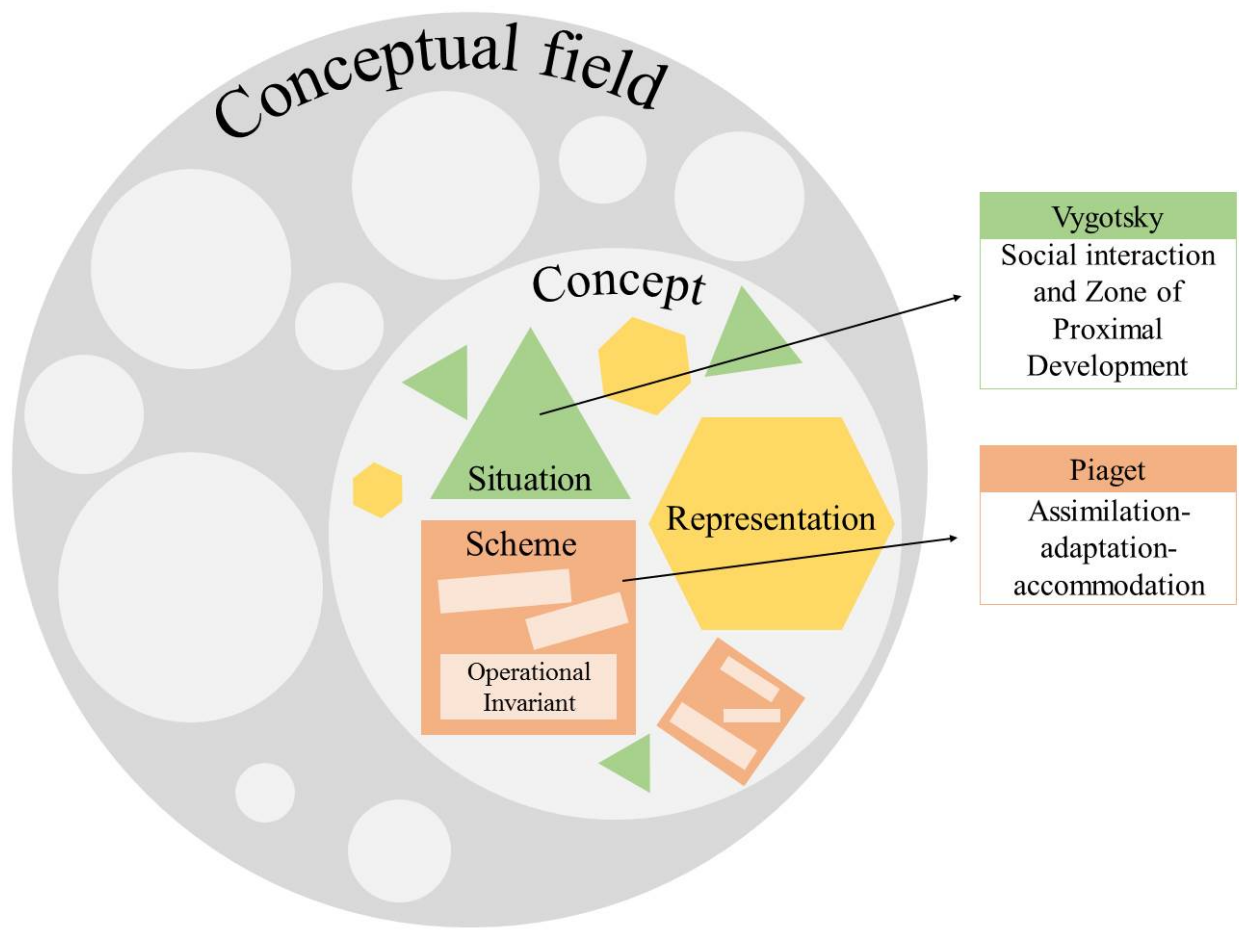

Figure 3.3. Outline of the student conceptualization model and its influential theories.

The level of conceptualization reached by the students, which includes the progressive mastery of the true concepts — with their operational invariants, domain of representations, and application to situations - will be equivalent to the level of competency development acquired. Obviously, to master a situation, students need schemes that require a different competency domain. This need is adequately addressed in its complexity from the proposal of an integrated STEM education via the adopted methodology, given that around the same conceptual field a very large number of situations allowing students to gradually achieve mastery of the field can be generated ${ }^{4}$.

\footnotetext{
4 Taking electricity as a conceptual field, closely related to the empirical example examined in the supplemental material, such situations could correspond to experiments on static electricity, inquiries with electrical circuits and their components - types of sources, conductive materials and insulators, types of receivers, etc.- - management of electricity bills, search for information on the uses of electricity, construction of models on the internal structure of the matter, etc.
} 


\subsubsection{Didactical axis}

Martinand's theory of the objective-obstacle has been adopted as a didactic support. Martinand (1986) proposes the existence of a dialectical relationship between the objectives of teaching and the obstacles standing in the way of achieving these ${ }^{5}$, which is how the objective-obstacle concept emerges. In this way, the objectives of Martinand's theory correspond to the objectives posed in an integrated STEM didactic unit. The obstacles represent the alternative notions students have about the contents addressed in that unit. Thus, obstacles may be of various kinds, related both to all the dimensions of competency and to the different types of competencies demanded by the problem addressed.

If the time available for the application of an ordinary didactic unit in the classroom is reduced, we consider that the objective a teacher must consider within the framework of integrated STEM education is not to overcome the obstacles but to try to undermine or crack the representations —in the sense proposed by Astolfi (1994)— that students have, which we call objective-representation. These representations are identified when students make explicit their operational invariants and their Vergnaud's representations. To create the objective-representation, the teacher should consider at least the minimum necessary representations (Martinand, 1988) and this will be the appropriate path for further overcoming larger obstacles and, often, obstacles of strong resistance. This approach is consistent with the notion that complete control of representations is an illusion (Martinand, 1988).

Given that the true objectives of scientific education need not be defined a priori and independently of the student's representations (Astolfi, Darot, Ginsburger-Vogel, \& Toussaint, 1997), the objectives of an integrated STEM didactic unit must be focused to confront and undermine the representations related to existing obstacles. These should not be skirted,

\footnotetext{
5 Martinand adheres to the theoretical framework of the French epistemologist Gaston Bachelard, who affirms that scientific knowledge is founded by undermining erroneous or poorly acquired prior knowledge acting as an epistemological obstacle for the development of scientific thought, either from the historical perspective or from the same educational practice (Bachelard, 1938). As such, epistemological obstacles are conceived as ideas or psychological elements that prevent, hinder, prohibit, block, or do not allow the appropriation or learning of objective knowledge -of reality; in other words, epistemological obstacles oppose the development of the scientific spirit.
} 
because they should not be considered a negative aspect in learning but something stimulating and dynamic (Astolfi, 1999; Astolfi et al., 1997; Bachelard, 1938; Martinand, 1986). In short, this theoretical framework pursues the creation of an integrated STEM education whose objectives start from students' representations or obstacles to improve their competency development.

This didactic approach is consistent with both the epistemological axis and the proposed psychological axis, assuming a possible way to undermine or crack representations and overcome more long-term obstacles underlying scientific problems (Laudan, 1977) that will be resolved within the domain of the conceptual field (Vergnaud, 1990) addressed in teaching.

An example of a real application of this theoretical framework for the design of a didactic sequence for primary school is provided as supplemental material.

\subsection{Implications and conclusions}

As well as we know the impossibility of conceiving the study of educational phenomenon from a single theoretical perspective, the same occurs in knowledge learning. Real problems transcend a unidisciplinary or single theory; the resolution of real problems is not the property of a single discipline. In contrast, it requires a wide range of contributions that transcend the content of a single discipline. Moreover, the eclecticism of the interdisciplinary often reveals new properties that would not be noticed in an isolated consideration. Regarding grasping the complexity of reality and the development of a complex thought distant from the blind intelligence produced by the one-dimensional and disciplinary simplification (Morin, 1990), integrated STEM and STEAM education emerges, a metadiscipline that integrates branches of literacy traditionally defined separately.

In this paper, a theoretical framework has been proposed for these two current multi-referential approaches of great scope, to improve the development of student competencies from a humanistic perspective; a framework that has largely been absent until now. The mechanism of the three levels of scientific commitment of Laudan has served to construct a theoretical 
framework to these approaches, founded on and consistent with both the depth and the essence of education.

From Laudan's perspective, this framework addresses a scientific problem: building a theoretical support for integrated STEM education that contributes to bringing it closer to a more formative and humanistic position and placing it in the educational setting with greater rigor and a commitment to the theoretical foundations of science education. The conceptual aspect of the problem represents the proposal of the theoretical framework itself. The empirical aspect implies to determine whether the integrated STEM education contributes to improving competency development in the students, that is, the verification of whether this approach is better adapted for competency development than those that have traditionally been used. The study of student achievements with these approaches is the most developed aspect in the literature (Brown, 2012; Mizell \& Brown, 2016), in addition to their creativity and problem solving skills, attitudes, and interests towards STEM subjects. The results can nevertheless be questionable since neither the aims nor the theoretical assumptions are always clearly stated.

Given the underlying theoretical complexity, some essential principles for integrated STEM education can be derived. We frame these principles in the three compatible support axes from the theoretical commitment, although given the theoretical interrelation, these principles should not be taken as intrinsic to the axes. Thus, from the epistemological axis we emphasize the importance of conceiving the teaching-learning process as a continuous exercise of problem solving — familiar to students_-, which is the essence of integrated STEM education and scientific progress. On the way to that resolution, we must not forget, as highlighted by Duschl (1990), the commitment with theories, with methods, and with the aims. This methodological structure will be useful for science teachers because it provides them a set of guidelines to help them plan and develop the science classes and didactic units (Duschl, 1990). The psychological axis emphasized the need for the generation of a great quantity and diversity of situations. In this way, students will have the opportunity to manage a set of operational invariants, develop, and verify schemes and to achieve the conceptualization or mastery of the conceptual field related to the issues addressed in teaching. Finally, regarding the didactical axis, we emphasize, in line with Astolfi (1999), the didactic usefulness of the objective-obstacle concept for integrated STEM 
education, both as a way of selecting the objectives of an educational sequence - around overcoming one or more representations - as well as to regulate didactic interventions - the concept serves as a tool to understand what students say and do- . It is also important to emphasize the importance of considering representations and obstacles as a form of knowledge, which traditionally does not happen (Astolfi, 1988).

Following Laudan (1977), this framework avoids two crucial and habitual conceptual difficulties: the justification of the use of certain methodologies congruent with the explanation of the process of students' conceptualization and the justification of the objectives or aims pursued. In addition, the framework allows the formulation of new questions that transcend most operational characteristics present in the literature about integrated STEM education, such as the following:

- Is any problem adequate to achieve the proposed purpose?

- What level and kind of competency does the student reach?

- What schemes related to the way in which science and technology are done are developed by students using these methodologies?

- What are the objectives-obstacles that have been and should be overcome?

- Which methods are more efficient — understood in terms of the domain of the conceptual field and of overcoming objectivesobstacles - in reaching the proposed goal?

Knowing that the elimination of conceptual difficulties involves both scientific progress and the increase of empirical support (Laudan, 1977), this theoretical framework is proposed intending to help offset a scientific advance so far largely led by empirical studies. Speculation, reflection, or philosophical thinking has been used to critically clarify an educational issue, a position that can allow the establishment of more humanizing educational reasoning (Gil Cantero \& Reyero, 2014). In addition, while the validation of scientific knowledge works with a certain degree of probability, scientific knowledge, in this case derived from existing and future empirical studies on the application of integrated STEM education, can be improved with the appearance of new theoretical knowledge. Likewise, the incorporation of this theoretical framework into the scientific knowledge of integrated STEM education can allow, through the holistic view provided by theoretical knowledge, the 
judgment of empirical works and the gauging of their scope and limits (Gil Cantero \& Reyero, 2014).

In this position paper, we have adopted a particular set of theories, which might limit this theoretical investigation. On the one hand, therefore, some specific theoretical aspects that are implicit to this paper might be enlarged (for example, relating to the sociocultural perspective and epistemic knowledge), and, on the other hand, other theoretical constructs could be adopted unlike the ones proposed here.

So, leaving open the doors to continuous theoretical improvement and scientific advancement, this theoretical framework could be useful towards the humanistic educational contextualization of integrated STEM and STEAM education, which is already in full swing and in many cases adhered to in the educational field without reflection and foundation being theoretically necessary. From a humanist perspective, this framework moves away from the more technical versions of STEM education criticized previously (Chesky \& Wolfmeyer, 2015; Zollman, 2012).

\subsection{Supplemental material: applied example of the theoretical framework in the primary education stage}

The proposed model was applied in the design, implementation, and evaluation of an integrated STEAM didactic unit of 19 sessions for the sixth year of primary education addressing the content of nature sciences, plastic education, and mathematics. These subjects are present in the Spanish curriculum and were taught in an integrated manner from the methodology of guided inquiry and the engineering design process. Starting from Laudan's epistemological view of problem solving, a main problem was posed: How can I design a lighting prototype for my study room? It may seem like a simple problem; nevertheless, it prompts the discussion of sustainability and production-related issues, such as the demand for electricity, which are closely connected with the interests of students.

Thus, contents related to electricity, such as static electricity, source types, series and parallel circuits, insulating materials and conductors, and energy transformations —science-, were covered. Information and 
communication technologies were used, and technological aspects related to electric energy, lighting and its advances — technology - were discussed. Work was done on the design of a lighting prototype for a specific room engineering - Content related to colour and its sensations — visual arts— was addressed, and information needed to decide upon which lamps to use considering cost, energy efficiency, and lifetime, among others - were managed as variables, tables, and graphs — mathematics - . It is worth stressing that the unit revolved around the solution of the initial problem and that its contents were addressed in an interdisciplinary manner as the students needed them to achieve a solution.

This didactic unit was design to improve the development of the seven key competencies proposed in the Spanish Educational System regarding the curriculum content related to the problem: linguistic communication, mathematical competency, basic competencies in science and technology, digital competency, learning to learn, social and civic competencies, sense of initiative and enterprising spirit, and conscience and cultural expressions.

Regarding the psychological and didactic level, the process of design, implementation, and evaluation began by discovering the representations, from Martinand's point of view, that students had in terms of the content addressed in the unit, for example, on electricity, the management of mathematical data, or colour. This process was carried out by consulting the information present in the specialized literature. It can also be done through a test application; the development of conceptual maps, diagrams, stories, reports, or drawings; and a long list of methods that give rise to the explanation and detection of representations or alternative ideas of students for further diagnosis. Then, some representations were selected that did not correspond to the scientific consensus and that were doable in the limited period of time in which the didactic unit was developed. Some of the representations selected were, for example, the belief that a battery is the only source of charge injected into wires like water in a pipe, that all types of graphs can represent any type of data, or that colour is an intrinsic property of matter. In line with Astolfi (1999), the criterion for selecting the representations to be addressed was determined by the value that its splitting implied for competency development. With the selected representations, objectives-representations were generated that guided the approach to the situations — from Vergnaud's perspective - aimed at undermining these representations. Taking, for example, the widespread 
representation that colour is an intrinsic property of matter, the objectiverepresentation of knowing the factors influencing the visual perception of the colour of an object was generated, which led the students to inquire about observing a folio illuminated with different coloured lights. From the integrated STEM education made viable through the adopted methodologies, each problem offers a great variety of situations for students, for example, for each hypothesis worked through. Thus, each inquiry or design proposed involves a myriad of Vergnaud-type situations from the student's point of view. The undermining or cracking occurs when the cognitive destabilization manifests itself, which has already been alluded to in the psychological axis. This phenomenon creates an approach to the objective that will ultimately —and through the development of more didactic units throughout the course and the educational stage - be the way forward to overcoming Martinand's objective-obstacle in the long term.

The entire process was operationalized by dividing the unit into four specific problems: What will our installation work with? How do we build our electrical installation? What kind of bulb do we use in our circuit? and What kind of light-emitting diode (LED) bulb should we use? Each problem was addressed through the characteristic phases of guided inquiry.

To elucidate the didactic process used in the design of the didactic unit, Figure 3.4 shows an example of the transformation experienced by one of its objectives from its traditional conception to its elaboration from the present theoretical framework. 


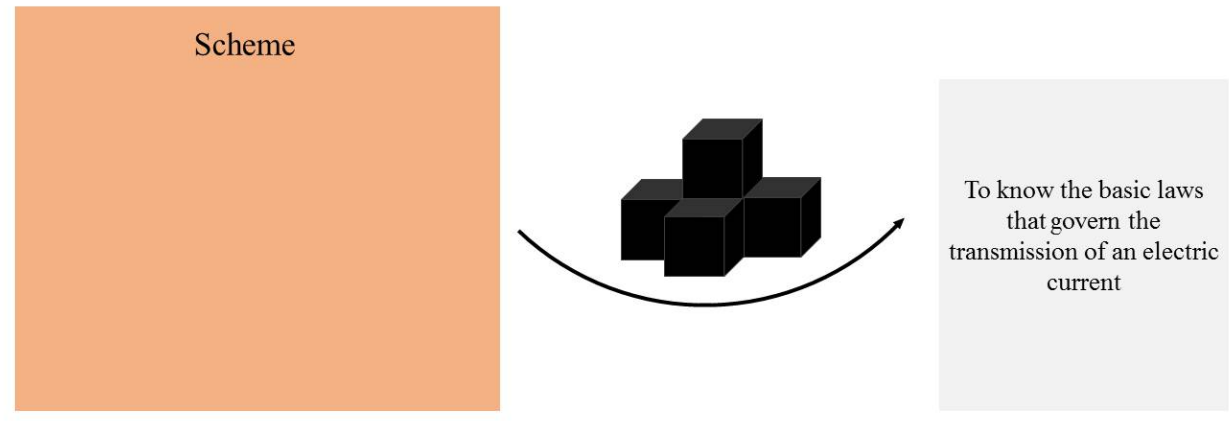

CONSTRUCTION OF OBJECTIVES FROM THE PRESENT THEORETICAL FRAMEWORK

\section{Scheme}

- The current supplied by the battery is consumed along the circuit

- An electric current is a substance - usually a fluid - that moves through wires

- The battery is the only source of charges that is injected into the wires similar to water in a pipe

- In an elementary circuit, the connection to a single battery terminal is sufficient to light the bulbs

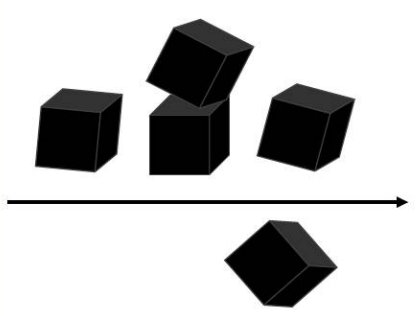

To know the chemical composition of the batteries

To understand the function of electrons in electrical currents

To understand the notion of a closed circuit

Figure 3.4. Transformation of a traditional objective into other objectives based on the present theoretical framework.

In the first case, the traditional construction of an objective, the objective of learning is constructed directly from the curriculum content, without considering the students' representations. The learning objective is created from a "blank" mental scheme. In addition, when students' representations with respect to the contents to be addressed are not known, the teaching process is focused on going around the obstacle, a situation that does not foster scientific learning. In the second case, construction of objectives from the present theoretical framework, although the learning objectives are logically related to the curriculum content, they are associated with the students' representations. Thus, within the integrated STEM education, the learning objectives are constructed considering the representations underlying their mental schemes as well as being focused or 
directed at the problems posed. In this case, unlike the previous case, the teaching process is focused on tackling the obstacle, allowing the overcoming of everyday life obstacles (Bachelard, 1938).

Finally, the level of the students' competency development was deduced through the evaluation of the learning standards corresponding to the unit implemented, in which the representations used by the students and the explicit part of Vergnaud's operational invariants expressed by students were evaluated. This level of competency provided relevant information to check and evaluate the extent to which the operational invariants were modified in the process of conceptualization and the implication on student representation, from Martinand's perspective. The analysis of the data collected after different implementations of the unit to a sample of $N=121$ students reported high levels of competency development —-more detail in Ortiz-Revilla et al., 2018a; Ortiz-Revilla, Greca, \& Meneses Villagrá, 2019-.

Figure 3.5 shows the triadic operating model corresponding to the described example.
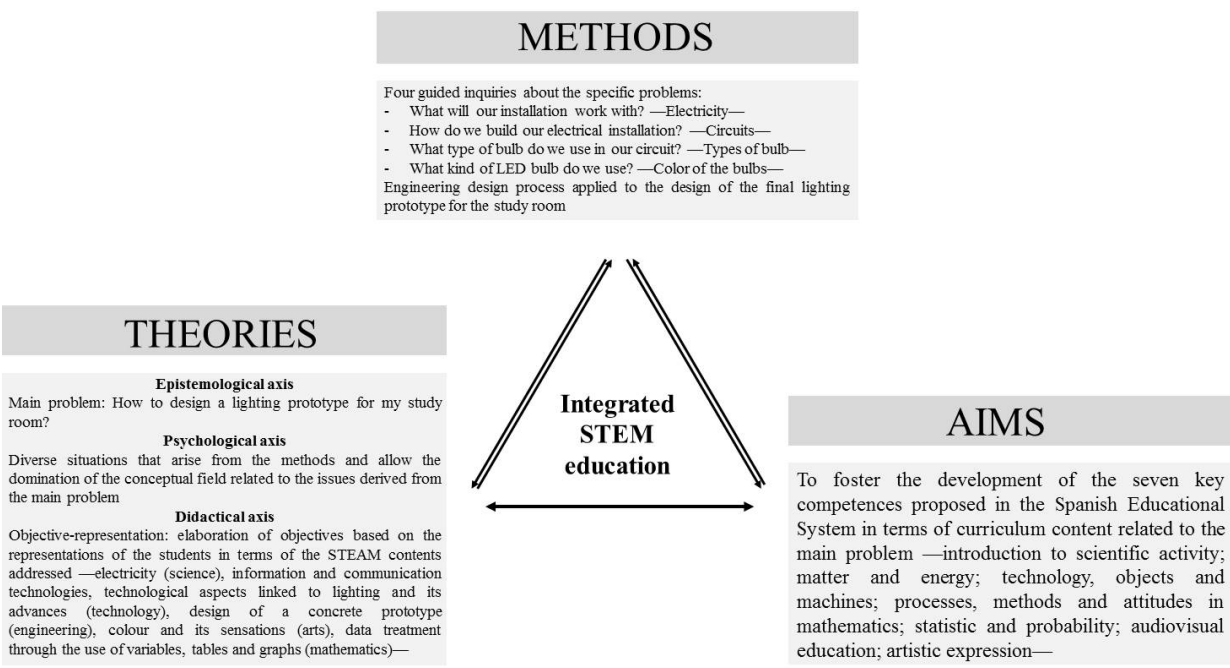

Figure 3.5. Model of triadic functioning corresponding to an example of application of the theoretical framework in the design, implementation, and evaluation of a STEAM didactic unit in the stage of primary education. 

CAPÍTULO 4

Un marco para la discusión epistemológica en torno a la educación STEM integrada 

$\mathrm{P}$ ara completar la fundamentación teórica de la investigación, este capítulo se ha orientado a esclarecer algunas cuestiones teóricas de la educación STEM/STEAM integrada, concretamente las relacionadas con sus implicaciones epistemológicas. Para ello, se comienza revisando la historia de su surgimiento y se propone su concepción desde una perspectiva humanista. A continuación, se analizan las relaciones actuales entre el conocimiento producido por las áreas de ciencia, tecnología, ingeniería y matemáticas. Este análisis nos lleva a adoptar un modelo de «tejido sin costuras» — seamless web- Algunos de los tópicos que emergen de esta adopción fueron considerados desde la perspectiva del modelo filosófico del «parecido de familia» — Family Resemblance Approach— para determinar unos rasgos potenciales para una naturaleza de la educación STEM integrada (NOSTEM).

Este capítulo se corresponde con el artículo de investigación que lleva por título en inglés «A framework for epistemological discussion around an integrated STEM education», que actualmente se encuentra en proceso de revisión. Por ello, se ha considerado adecuado presentarlo manteniendo la estructura del propio artículo. Solamente se han omitido las referencias bibliográficas, que se presentan compiladas en el Capítulo 9. Así mismo, este capítulo contiene información de un trabajo preliminar realizado en torno a esta temática (Ortiz-Revilla, Greca y Adúriz-Bravo, 2019).

\subsection{Abstract}

The disciplines encompassed in "STEM" — Science, Technology, Engineering and Mathematics- have long been studied from an eminently monodisciplinary paradigm. "Integrated STEM" education is the most recent interdisciplinary proposal and, under its umbrella, disciplines are beginning to be integrated in an educationally fruitful way. Such an approach is becoming more common nowadays, but the available philosophical views on it are still on its infancy, with most of its epistemological aspects absent or blurred. The overall aim of this paper is to establish an initial framework for philosophical discussion to help analyse the aims and discourse of integrated STEM education with consideration of the implications that adopting any particular epistemological view will have on the aims for general education and on the construction of society as a whole. We envisage humanist values for integrated 
STEM education and, after revisiting the current relationships between the knowledge areas in STEM, we adopt a "seamless web" model for those relationships. Some of the issues emerging from this model are addressed through the lenses of the Family Resemblance Approach in order to obtain some potential features for a nature of STEM.

\subsection{Introduction}

The disciplines referred to by the acronym STEM have long been studied as separate school disciplines, from an eminently mono-disciplinary paradigm, which has already been called the "simplistic reductionism of traditional teaching" (Connor et al., 2015). Inter-disciplinarily has a theoretical background of its own and a fairly broad range of conceptualizations (Chubin, Porter, Rossini, \& Conolly, 1986; Klein, 1990; Torres Santomé, 1994); although approaching — from a historical point of view — the conceptualization of this notion may imply going back in time to philosophers such as Plato, such concept has been mainly studied during the 20th century, from different theoretical perspectives. The notion of interdisciplinarity in education has also been examined in the last hundred years. For instance, American pedagogue John Dewey (1929) analysed the educational science as a field integrated by various disciplines aiming at scientifically studying the different aspects of education, understood as a complex social phenomenon in several spheres of action. On the other hand, the Austrian philosopher Karl Raimund Popper (1963) considered that scientists did not study disciplines but problems, which can traverse disciplinary bounds.

There has been sustained criticism to traditional teaching supported by a simplistic and reductionist approach to human knowledge and treating each school discipline separately (Connor et al., 2015). Taking an interdisciplinary stance, didactics of science - i.e. science education as an academic fieldbegins to construct a new educational meaning for the acronym STEM, seeking to foster students' literacy in the constituent disciplines through the integration of knowledge coming from them (Bybee, 2013). In accordance with this, in the current literature of science education we can find several proposals for the integration of some — or all — of the disciplines in STEM; for example, science and mathematics integration has been vigorously pursued since the 1930s 
(McBride \& Silverman, 1991) and the integration of science and technology has been at the core of numerous humanist science education perspectives (Aikenhead, 2015) ${ }^{6}$. More modest interactions between the four STEM disciplines — and with other fields such as history of science or arts - had already been proposed, without using the well-known STEM nomenclature, with the aim of constructing a broader basis for science education (Gallagher, 1971; Hurd, 1975). "Integrated STEM education" is the most recent proposal, and it seems that under its umbrella disciplines are beginning to be integrated in a more educationally fruitful way. Albeit confronted by quite a few critical voices (see, among others, Chesky \& Wolfmeyer, 2015; Garibay, 2015; Hoeg and Bencze, 2017; Zeidler, 2016; Zollman, 2012); such approach is expanding nowadays, and there is a significant volume of scientific production around it (Brown, 2012; Mizell \& Brown, 2016). In addition, its benefits in student scientific literacy, primarily through the application of certain methodologies such as inquiry, engineering design or project-based learning, are increasingly being emphasised in studies (Bybee, 2013; Capraro et al., 2013; English \& King, 2015; Martín-Páez et al., 2019; NRC, 2011, 2014; UNESCO, 2017; Wang, Moore, Roehrig, \& Park, 2011). However, in order to give substantive meaning to an integrated STEM education, it would be necessary to reflect explicitly upon philosophical issues. Therefore, the overall aim of this paper is to establish an initial framework for philosophical discussion to help analyse the aims and discourse of integrated STEM, in order to give educational rigour to this approach and not to throw the baby out with the bathwater.

It is worth stressing that we here focus on the use of integrated STEM approaches in compulsory education, in particular in primary and lower secondary school, since the foundations of STEM competence and long term interest were established for early childhood education (Australian Council of Learned Academies, 2013; Mullis, Martin, Foy, \& Arora, 2012).

\footnotetext{
${ }^{6}$ The objectives of preparing students to understand global challenges and to actively participate in decision-making processes have produced several "S\&T" integrated approaches, such as science for citizenship, scientific literacy; S\&T literacy; the movement around SSI; education for sustainability; the Science, Technology, Society and Environment perspective; and socio-cultural perspectives for science education (see Aikenhead 2015).
} 


\subsection{Revisiting the history of integrated STEM education}

As a starting point for establishing a framework for philosophical discussion, it is necessary to know the origins and historical evolution of integrated STEM education. Since this historical evolution is described in detail in the literature (see Breiner et al., 2012; Bybee, 2013; Sanders, 2008), we retrieve here only the basic historical events and topics essential for the subsequent understanding of the philosophical foundations of STEM.

It is often argued that the interest in STEM as a major focus of general education may have originated in the 1940s with the prelude to the creation of the National Science Foundation (NSF); such interest would have accelerated with the launch of Sputnik in the late 1950s. The NSF was created in 1950, materializing the view on scientific progress of Vannevar Bush (1945), the then Director of the Office of Scientific Research and Development. Bush was summoned by President Franklin D. Roosevelt in order to help in configuring the application of scientific knowledge in times of peace (England, 1976). As Ramaley, Olds y Earle (2005) express: "NSF has from its beginning been authorized to initiate and support education programs in all of the fields of science and engineering, at all education levels, beginning with the graduate research fellowship program in the early 1950s" (p. 176). Breiner and colleagues (2012) noted that, from the early 1980s, reports were released showing a strong interest in strengthening science, mathematics and technology education in the United States since early childhood. Such interest had become apparent by that time, for instance from the National Science Board (NSB) within NSF (NSB $1969 \mathrm{a}, 1969 \mathrm{~b}, 1986)$. Thus, at the beginning of the $21^{\text {st }}$ century the NSF was described as "the only federal agency with such a broad and comprehensive mission in STEM education" (Ramaley et al., 2005, p. 176).

In relation to the origin of the acronym, the NSF, after a series of changes in the letters included and the order in which they were mentioned, has been consistently using "STEM" since the 1990s to refer to the curriculum of the four disciplines and later to describe several of its projects of literacy whether integrated or not. Sanders (2008) underlined that due to the concern of the United States that the country might fall behind in global economic competitiveness, STEM-related funding began, and "STEM-mania" emerged. 
However, we think it is necessary to qualify this historical "narrative", since the historical evolution of STEM lacks the continuity with which it has usually been narrated. There exist, in this "movement", discontinuities and reappearances, that is, moments in history in which there was not so much interest in STEM and other moments in which its emphasis is clearly appreciated. For example, the historical discourse of STEM education forgets the legacy of the STS movement — science-technology-society- By the end of the 1970s and beginning of the 1980s, STS perspectives in science education proposed using the interactions between scientific knowledge, its related technologies and societal issues as a context for technoscientific literacy (Rip, 1979; Spiegel-Rösing \& de Solla Price, 1977; Ziman, 1980). DeBoer (1991) characterises science-society teaching as "humanistic, value-oriented and relevant to a wide range of personal, societal and environmental concerns" (pp. 178-179). As the STS movement promotes a more holistic view for science education, it was seen as a radical shift from status quo (Aikenhead, 2003). STS also shared many features with the education for sustainable development, thus evolving towards what would later be known as STSE, with the addition of the environment (Vesterinen, Manassero-Mas, \& Vázquez-Alonso, 2014). Such shift in essence also appears in STEM education, in the versions that are more occupied with sociocultural issues (Zeidler, 2016). Nevertheless, the STS movement has several differences with the current STEM proposals; among them, its roots and goals. STS was primarily promoted by post-war scientists who felt they had a responsibility to the public due to the environmental impact of scientific and technological developments. Also, a root of the movement can be found in the seminal work by C. P. Snow on the "Two cultures", in which he proposed to break the barriers between arts, humanities and science, "particularly in post-compulsory education" (Ratcliffe, 2001, p. 84). In terms of aims, the main original goal of the STS movement was not linked to pursuing scientific vocations, but to bringing the scientific education of university and high school students closer to their needs as critical active members of increasingly technological societies. It is worth stressing that the momentum gained by the STS approach in the 1980s in the UK and USA had no long-term impact on mainstream, discipline-based curriculum technicians; it only had restricted effect on science education through some special projects and programmes, with no recognisable influence on traditional technology education (Williams, 2011). The main reasons for this are that innovative curriculum models are difficult to produce; there is little STS instruction in 
teacher education programmes; and the accumulated research results about the efficacy of STS instruction are inconclusive (McComas, 2014). These are lessons to be learnt in the current STEM movement (Williams, 2011).

In 'standard' presentations of the nature and history of STEM education, another important point is also usually omitted: understanding STEM as several school disciplines integrated by the ethos of engineering, which can be understood as "design" and not as the academic discipline strict sensu (Bequette \& Bequette, 2012; English \& King, 2015). In fact, this 'designbased' meaning of STEM is very much in line with the more recent and interesting STEAM approach, especially in compulsory education. For some scholars, as Quigley and Herro (2016), "the goal of this approach is to prepare students to solve the world's pressing issues through innovation, creativity, critical thinking, effective communication, collaboration, and ultimately new knowledge" (p. 410). In this sense, there are now many voices pointing out that contemporary, design-driven STEAM is more genuinely integrated and balanced than its predecessor (Madden et al., 2013; Quigley \& Herro, 2016).

The fact is that STEM has long been used as a generic label to mention any event, policy, programme or practice involving one or more of its constituent disciplines, whether integrated or not (Bybee, 2010; Martín-Páez et al., 2019); it thus became a familiar overarching acronym. It is only recently that the idea of interdisciplinarity has been included in STEM; however, the label still has an ambiguous meaning. On the road to the disambiguation, several challenges emerge (Bybee, 2013): including technology and engineering in STEM's traditional, restrictive conception of science and mathematics; contextualising problems away from simple knowledge of concepts and procedures; and concreting its precise educational meaning(s). In this context, the conception of integrative STEM education or integrated STEM education represents the intentional integration of the various disciplines used to solve real-world problems (Sanders, 2008), which accommodates diverse variants according to the number of integrated disciplines and the way in which the integration is done (Bybee, 2013).

In the present proliferation of an enormous variety of integrated STEM education programmes, very different epistemological points of view can be recognised. Some of them are discussed below. 


\subsection{A humanist perspective for integrated STEM education}

Although the main focus of this position paper is to point out some epistemological aspects of STEM, the analysis of those aspects is inseparable from axiological considerations. We consider that the adoption of certain epistemological views inevitably influences the type of values proposed for integrated STEM education and vice versa. For example, the adoption of a position informed by the theoretical ideas of sheer syntactic analysis and strong separation of knowledge from context propounded by logical positivism — the foundational school of the philosophy of science, in the 1920s - does not fit with a humanist view on the active, transformative role of science in a democratic society; conversely, a depiction of science education as substantive contribution to collective, critical participation in SSI is hardly compatible with the technocratic, elitist, value-neutral tenets of the so-called "received view" of the philosophy of science, which reigned in the Anglo-Saxon academic community after the Second World War and until the 1970s.

For the time being, perhaps the most widely adopted axiological framework on integrated STEM education is the one more or less explicitly chosen by the United States in its STEM education reform initiatives, which focus on meeting economic needs, such as competitiveness. In this sense, several criticisms have been advanced, especially with regard to the "sociopolitical silence" that is apparent in a lot of STEM policies (Chesky \& Wolfmeyer, 2015; Gough, 2015), which makes it "unlikely [that] students will engage in criticism of STEM processes and practices that support economic growth, and instead will orient students to support them" (Hoeg \& Bencze, 2017, p. 857). Nevertheless, we believe that another approach to integrated STEM education is possible. As we said, it is clear to us that only some epistemologies fit with the humanist values that we envisage; we consider STEM education as a very powerful means towards competence development and critical citizenship (Ortiz-Revilla, Greca, \& Adúriz-Bravo, 2018d), as opposed to sheer technical instruction. This view is not compatible with any epistemological approach: we need to retrieve conceptions of science, maths, engineering and technology that move away from technocracy and conceptualise disciplines as social organisations, knowledge communities and cultural legacy. 
One big lesson that we learned from the so-called "new philosophy of science" of the 1960s to 1980s is that the scientistic view that dominated metascientific reflection in the $19^{\text {th }}$ and the $20^{\text {th }}$ century scarcely captures the complexities of the relationships between science, society, culture and values; our proposal is to detach integrated STEM education from its original ideological matrix, which does not contemplate such lesson. Such task is possible with many powerful educational ideas; it has already been done with IBSE and with competencies as curriculum elements, among other topics. The ideological origins of the concept of STEM, in our opinion, would not matter in our educational context; what is essential is that the resulting, recontextualised approach is pedagogically powerful and compatible with the current socially proclaimed aims for education. The philosophy that we want to select for STEM should be directed towards infusing a humanist worldview into science curricula that is compatible with fully engaged citizenship (Hodson, 2006). For example, two recent schools of the philosophy of science, namely post-Kuhnian philosophy of science and the so-called "semantic view of scientific theories", seem very promising in constructing a "temperate" or "third-way" view of science — and perhaps of its relations with technologythat recognises its extremely relevant achievements without hiding its problems and shortcomings. Such schools could also provide elements to conceptualise mathematics, computation, engineering, design and technological innovation.

Finally, and along the same line of pursuing a more humanist perspective for integrated science education, we believe, as we indicated before, that STEAM education presents itself as a more balanced option. It is our contention that any STEM proposal that does not include the contribution of the arts, the transversal focus of design, the drive for disciplinary integration, and a discussion of values "necessarily excludes important areas that inform and contextualize science by grounding them in sociocultural contexts" (Zeidler, 2016, p. 17).

\subsection{On the search for an epistemological nature of an integrated STEM education}

Is there a "nature of STEM"? This is not the first time this question has been asked (Akerson et al., 2018; Peters-Burton, 2014), but in the first place it should 
be acknowledged that such question is inspired in the study of the "nature of science" (NOS), which is an educational construct. From a philosophical point of view, there is no such thing as the NOS — or of other disciplines-, in the sense that it is very difficult to determine a set of necessary and sufficient traits to univocally characterise science as a human activity, and that any of the possible characterisations that we can produce are always partial and inevitably theory-laden. Accordingly, the expression "nature of STEM" should be understood metaphorically, just as with NOS: for the last three decades, the community of didactics of science wanted to establish a shared set of "big" ideas with educational value on what science is in order to teach them to science students - and teachers - within the area of science in the curriculum. According to this perspective, asking the question of the nature of STEM should entail determining the most important characteristics of the different disciplines involved -and of their historical and current relations- that can be transformed into educational content.

Although the nature of integrated STEM education seems to imply a "nature" of higher level than the sum of the "natures" of its four separate disciplines, it is necessary to part from these in order to locate and analyse the epistemological views that the STEM approach could adopt.

As it is well known, the study of the NOS, although controversial, has been extensively addressed (Acevedo Díaz, 2008; Adúriz-Bravo, 2005; Lederman, 1992, 2010; McComas, 1998). But the same cannot be said with regard to the nature of the rest of the disciplines. Fewer publications have focused on studying the nature of technology (NOT) (American Association for the Advancement of Science [AAAS], 1993; Clough, Olson, \& Niederhauser, 2013). Based on not too many studies of engineering as a discipline from philosophical, historical, sociological, and pure engineering perspectives, Pleasants and Olson (2019) have recently synthesized key dimensions of the nature of engineering (NOE) for K-12 education. Finally, although the discussion about the philosophy and foundations of mathematics - loosely identifiable with NOM - comes from ancient times and has ample development (Dossey, 1992; Ernest, 1992, 1993; Lerman, 1990), these issues have not been the subject of as much educational research as that devoted to NOS.

As indicated above, epistemological aspects are often absent in research and innovation studies on integrated STEM education. On the other hand, and 
although there are different perspectives on the integration of STEM, most of the proposals focus on the study of science and mathematics (Bybee, 2013; Kelley \& Knowles, 2016), with less developed and often more inconclusive research on the integration of technology and engineering (Herschbach, 2011; Hoachlander \& Yanofsky, 2011; Williams, 2011), as these disciplines are not usually explicitly present in compulsory education (NRC, 2011). This has evident repercussions on deepening the epistemological analyses. The most prominent disciplinary field analysed from this "nature-of" point of view is undoubtedly science - i.e. the natural sciences-, with the epistemological aspects belonging to the rest of disciplines being until now mostly ignored in educational literature. Chesky and Wolfmeyer (2015) are some of the few authors that discuss deeply these aspects, mainly addressing mathematics and science, and the relationship of both disciplines with technology. In summary, a deeper analysis of the studies on integrated STEM education shows that STEM's epistemological issues are overlooked, veiled due to the complexity of its disciplinary relationships. We will select here some salient epistemological features from each of the four integrating disciplines.

Within a STEM integrated framework, Chesky and Wolfmeyer (2015) state, for the nature of mathematics (NOM), that it is important to conceptualise numbers and other mathematical entities as relationships that do not exist per se, but rather as - cultural — constructs that frame our possible ways of seeing the world, thereby excluding alternative conceptions of reality (Warnick \& Stemhagen, 2007).

In the case of the NOS, academic production is overwhelmingly abundant. For almost three decades now, didactics of science has analysed science as a process and as a product from a variety of philosophical perspectives, and has produced "key ideas" on its nature that are suitable for teaching in the science classes. There is nevertheless an emerging consensus that an approach integrating more "meta-scientific" perspectives is needed in order to convey a more educationally valuable depiction of the scientific enterprise (Erduran, 2014).

Before we can begin to talk of the NOE, it should be necessary to have a definition of what engineering is. But there is no single accepted definition of engineering in the literature of engineering education or of the philosophy of engineering. Not even is there consensus on the centrality of design within engineering: design-oriented conceptions of engineering exist —opposite to 
modelling this discipline after the natural sciences_- especially since the 1960s, but Houkes (2009) remarks that they are typically counter-movements instead of a new orthodoxy, if the curricular structure of engineering schools in most countries is analysed. Nevertheless, although acknowledging that engineering involves much more than just design, several authors in science education consider design as a central feature of the NOE, because of its prominence in the academic literature and in educational settings (Pleasants \& Olson, 2019). Another central feature of NOE that is being proposed in recent papers in science education is that any engineering production design must attend to both the internal workings of a technology and its function in a social environment. Engineering translates "ill-defined goals" into specifications that can be used to guide design work, while taking into account design constraints — safety, reliability, costs, sustainability, etc. — that limit the possible solutions and should have to be socially negotiated (Antink-Meyer \& Brown, 2019; Pleasants and Olson, 2019). While constraints demonstrate how engineering is limited, it is worth stressing that not all constraints can be overcome, since some problems are simply not technological in nature (Waight \& Abd-ElKhalick, 2012).

Despite its relevance for citizenship, technological literacy and the nature of technology (NOT) have received insufficient attention in science education (Pleasants, Clough, Olson y Miller, 2019). Indeed, a study among leaders of professional organisations representing science, engineering and mathematics concluded that there is no consensus on the perception of what "technological literacy" should entail (Rose, 2007). Educational discourse around science teaching tends to show naif or out-dated ideas about technology, presenting it mainly under an instrumental conception, which aligns it with "applied" scientific research and values it only for its role in solving concrete human needs (Waight \& Abd-El-Khalick, 2012). Nevertheless, in the last few years this view has begun to be questioned. Waight and Abd-El-Khalick (2012) describe five dimensions that need to be considered for NOT, associated with perspectives coming from contemporary philosophy of technology: technological progress, technology as part of systems, technology as "fixed", the cultural context of technology, and the role of values, expertise, innovation, creativity and invention. Pleasants et al. (2019), based on an extensive analysis of philosophical writings on technology, offered some questions organised by different levels of relevance for personal and 
societal decision-making that should be included when dealing with NOT in a more thoughtful and ethical STEM education.

A philosophical problem in the construction of NOT and NOE is that technology and engineering cannot be identified exclusively in terms of the existence of an independent body of systematic knowledge with academic autonomy (Meijers, 2009) or in terms of their own methodology (Mitcham and Schatzberg, 2009). As Meijers (2009) highlights, "Technology or engineering is primarily a practice which is knowledge-based. In this practice scientific knowledge, but also experience-based know-how, codes and standards, customer requirements, organizational, legal and economic constraints, physical circumstances, scarcity of resources, uncertainty and ignorance play an important role" (p. 3). So, a strictly methodological demarcation among applied science, engineering, technology and design is clearly insufficient to produce ideas with educational value and to seek for fruitful integration between these fields.

\subsection{A model of "seamless web" for understanding the knowledge produced by STEM disciplines}

Is it possible to address the nature of STEM (NOSTEM) as just the sum of the natures of the four constituent fields $\mathrm{NO}(\mathrm{S}, \mathrm{T}, \mathrm{E}, \mathrm{M})$ ? Which are the similarities and differences in the knowledge produced by them? What are the possible synergies? What emergences occur in their combination and integration?

Antink-Meyer and Brown (2019), based on a review on the literature of philosophy of science and engineering and science education, describe the primary distinction between engineering and science as teleological. Using Vincenti's words (as cited in Antink-Meyer \& Brown, 2019): there is a "fundamental difference between engineering as the creation of artifacts and science as the pursuit of understanding" (p. 541). But engineering practice, design and management, although involving knowledge and enabling the acquisition of knowledge, "are not primarily knowledge-producing activities" while "engineering science is" (Houkes, 2009, p. 313). So, the precedent statement can be reframed as follows. In the case of science, knowledge about natural phenomena is an end in itself, while engineering science generates 
models of phenomena that produce useful results — in the form of some kind of product-, even if they offer little explanatory power. This is an example of what Houkes (2009) calls the "truth vs. usefulness" intuition: scientific knowledge aims at finding out "true" — i.e. valid — theories, while engineering knowledge aims at practical usefulness —an intuition that conflicts with an instrumentalist view of science-. But, as Stephen Toulmin among other authors has noted, after World War II the basic focus of scientific research was no longer nature itself, but some "unit" of engineering artefacts, such as a reactor, a missile, or a computer.

In a similar way, many authors have sought to study the differences between science and technology in strictly axiological terms, showing that they mainly differ in their aims, values and actions. According to this approach, the central goals of science would be epistemic, i.e. the creation of knowledge that explains, while the aim of technology could be depicted as the construction of things or processes with some socially useful function. These distinctions are anchored in Mario Bunge's idea of technology as applied science, which is called the "linear model" of the relationship between science and technology, a theoretical framework widely spread among the general public and shared by many stakeholders, but frontally questioned in the studies about the philosophy of technology and engineering. In addition, a review about the several ways in which authors have tried to establish an "epistemic emancipation" of technological knowledge from its scientific counterpart shows that most of the available studies have not produced refined discussions about this issue and have accordingly failed so far to establish strong arguments for the complete autonomy of technology (Houkes, 2009, p. 342).

Regarding the differences between technological and engineering knowledge, it has been argued that engineers are more involved with applied scientific knowledge and technologists focus "more on the actual construction" and operation (Mitcham, 1994, p. 144), but current practices in technology seem to blur this distinction. Although historically some technologies were developed via trial-and-error - for example, the use of drugs for medical treatments-, or slowly and iteratively modified through the work of skilled artisans and craftspeople — for example, the bicycle—, modern technological development differs from these previous modes due to its close relationship with scientific knowledge (Kroes, 2012; Marcus, 1996). 
Several scholars argue that considering science, technology and engineering as separated epistemological practices do not take into account the richness and variety of actual scientific and technological practices, since designing and constructing material things or processes are also frequent activities in science (Radder, 2009; Tala, 2009). Not only so, as Latour (1987) and other authors that support the notion of technoscience point out, scientists, engineers and technologists are centrally involved in practical processes of intervention, negotiation and construction and, in the course of the 20th century, science has increasingly become "big science", requiring the formats of an industrial organization. Large, multinational research groups are involved with scientific design and testing of experimental machines, accelerators and detectors (see, for example, Galison, 1997). Scientists, including mathematicians, use technology to produce models, to perform experiments, to manipulate and store data, to write research papers, and to communicate with other scientists.

Finally, theoretical physics, chemistry and biology, parts of engineering and many other academic fields overlap with applied mathematics. Not only discrete mathematics, statistics, computational science and data science are key for the current development of all scientific, technological and engineering endeavours, but also mathematics is in turn affected by technology, with computers being used in "experimental mathematics" to justify mathematical claims and to produce brute calculation for suggesting or testing general claims (Avigad, 2008).

So, how can the relationships between science, technology, engineering and mathematics be addressed? The models proposed by social scientists on the "nature" of those relationships can be divided in three groups (Radder, 2009, pp. 24-25):

a) Primacy models, in which some kind of primacy -empirical, conceptual or evaluative - is given to one of the areas. The "humanities tradition" in the philosophy of technology is used to emphasise the practical basis of engineering and science, giving primacy to technology, while the engineering tradition, stressing the scientific basis of engineering and technology, will be inclined to assign primacy to science.

b) Two-way interactive models, which assume that technology, engineering and science are independent, yet interacting, entities. 
c) Models assuming a "seamless web" between technology, engineering and science, which state that these activities are so strongly intertwined that they cannot be sensibly distinguished. Because of the claimed seamlessness, proponents of such models often use the notion of technoscience. These models capture more accurately most modern technological and scientific practices, especially in the era of big science (Haraway, 1997; Latour, 1987).

Given the educational aims of STEM that we envisage, centred on contributing to a general science education for all and to the preparation of citizens, we consider that an integrated STEM approach for primary and lower secondary science should adhere to a "seamless-web" understanding of the relationship of science, technology and engineering, and also including mathematics. Such understanding seems to be appropriate to anchor a useful NOSTEM for compulsory education.

\subsection{A possible philosophical framework for integrated STEM education: the "family resemblance approach"}

In an effort to define a philosophical framework for NOS able to grasp the richness and dynamics of science, Irzik and Nola (2011) adopted Wittgenstein's family resemblance approach (FRA), considering the different natural sciences as cultural entities in a "family" with many shared characteristics, that are similar across sciences, as well as other specific traits that make each science unique. The FRA can then accommodate both the domain-general and the domain-specific features of science, assuming, as we pointed out above, that it is not possible to determine a set of necessary and sufficient conditions for defining science.

Following Irzik and Nola, science can be understood as a cognitive and social system whose investigative activities have a number of aims achieved with the help of methodologies, methodological rules, and systems of knowledge certification and dissemination. These elements are in line with institutional, social and ethical norms. When the alignment is successful, science "ultimately produces knowledge and serves society" (Irzik \& Nola, 2014, p. 1014). In our view, this framework is quite appropriate as a basis for sketching how an epistemology of integrated STEM, understanding the label as a seamless web of disciplines, would look like. We are briefly presenting 
some of the epistemic features that could characterise such a NOSTEM, features that are not much stressed in the scarce literature about epistemological issues in integrated science education. We will have in mind the dimensions proposed by Irzik and Nola (2014) and our humanist approach to STEM, aiming at the education for all.

Related with the aims and values of integrated knowledge production in a seamless web of disciplines, the ultimate goal of the disciplines integrating the web of STEM should be the responsible resolution of relevant societal problems within a sustainability matrix. Such idea would be in the core of the family resemblance between science, technology, mathematics and engineering. Each of these four constituents, in their turn, would have their own separate goals - the development of solutions, the understanding of nature, the production of machines, the design of processes, etc.- - and such goals could be discussed with students for their integral literacy.

Related to methods, integrated STEM education should stress that nowadays the frontiers between areas are blurred in the seamless web of STEM practices, a point that is not usually highlighted. For example, as Radder (2009) argues, scientific practices include "the regular application of a variety of rules of thumb and intuitive models for solving (...) problems, the making of approximations based on mathematical or computational feasibility and the black-boxing of (parts of) systems through tuning to experimentally determined parameters" (p. 73). These features can be seen in simulations (Greca, Seoane, \& Arriassecq, 2014). However, these procedures have been characterised as typical of technology according to several scholars such as Bunge.

Modelling, a core characteristic of the scientific mode of knowledge production, is used in engineering in a number of forms - conceptual, analytical, numerical, physical... - as a means of gathering and organising data and getting feedback (Pirtle, 2010). In the engineering sciences, modelling is a strategy to understand, predict or optimise the behaviour of devices or the properties of materials - real or possible- In technology, modelling is usually used to represent the design of a device or its functioning (Boon \& Knuuttila, 2009).

On the other hand, within this framework that understands STEM as a seamless web, experimentation and design have attracted increased attention 
(Tala, 2009), because during these activities the world is simultaneously written and read technologically in two senses: some of the phenomena are instrumentally revealed, while increasingly more phenomena "are technologically produced and tailored" (Tala, 2009, p. 283). Scientific knowledge is not simply "discovered" from nature, but constructed through careful and well-planned experimentation and the accompanying interpretation of the experiments. So, when experimentation is addressed, scientists rely, as engineers, on scientific design, which aims, like engineering design, at the control and manipulation of material laboratory phenomena, as a basis for success (Tala, 2009). In particular, technoscientific research is full of tools "to make something happen", which belong to a specific style of laboratory experiments aimed at manipulating objects and properties (Hacking, 1983), and not just testing hypotheses or representing nature (Vincent \& Loeve, 2018). Thus, design is not an exclusive feature of engineering. Furthermore, as Vincent and Loeve (2018) stress, "where knowing and making are intermingled, nature itself comes to be viewed as a designer" (p. 176). Design is, then, the ideal type of research of technoscience, which may still co-exist with the traditional modes of observation and experimentation. Some branches of Mathematics are also using today an experimental methodology, based on computational methods for obtaining, verifying, and confirming knowledge; suggesting theorems and making conjectures plausible; and providing insight and understanding (Avigad, 2008; Borwein \& Bailey, 2004).

Addressing the issue of the kinds of knowledge produced by the STEM disciplines, it is interesting to highlight three features. First, designing functional objects and organisms is an end in itself rather than a means toward an end (Vincent \& Loeve, 2018). Second, people involved in technoscience scientists, engineers, technologists - consider that a proof-of-principle constitutes a genuine and valuable instance of knowledge-production. Such knowledge, from the point of view of the traditional conceptions of engineering, was seen as temporary and limited, calling for further research and development efforts in order to be scaled-up (Vincent \& Loeve, 2018). Third, within the seamless-web metaphor, innovation is also valuable knowledge - a point which is addressed below-.

The FRA model includes a dimension of practice, dealing with the set of epistemic and cognitive practices that lead to consolidating knowledge, processes and products. In the case of technology, there would be specific 
practices to attain the closure and stabilisation of a particular technology, strongly resembling the consensus reached in science after alternative interpretations of a phenomenon are discussed. Pinch and Bijker (2012) define "closure" as the consensus emerging when it is considered that the problem motivating the development of a technology has been solved. Closure is more complex in engineering and technology that in science, since the variety of groups involved in the production - that is, in the definition of the problemand in the ratification of technology is greater —among them, individual inventors, scientists, design and production engineers, firms or state agencies, consumers, sales and marketing teams, financial advisers, lawyers, politicians...-. In addition, although a solution can be reached, many more problems emerge - some of them beyond the tractability of the original problem - as the technology is developed and expanded to other contexts (Hughes, 2012; Volti, 2014). Thus, unlike in science or mathematics, in technology different groups may define differently the problem and the success or failure. Despite these differences, the family resemblance holds, insofar in the case of science "nature is never used as the final arbiter since no one knows what she is and says" (Latour, 1987, p. 97).

Other issue around practices in the STEM disciplines has to do with the processes of validation, which seem to be more or less clear in science (although at present simulations are disputing our traditional understanding of validation, Greca, Seoane, \& Arriassecq, 2014) but has not been as thoroughly studied in engineering science, in which it is plausibly related to practical usefulness (Houkes, 2009).

One striking difference between scientific, engineering and technological knowledge is around the dissemination of results. One of the classical, implicit norms in science it that scientists cannot claim ownership of knowledge and they have to transparently communicate their results and the way in which they were achieved (Merton, 1973). It happens quite differently in the world of engineering and technology, where the "degree of expression (or codification) of technological knowledge may be largely due to socioeconomic circumstances" (Houkes, 2009, p. 336).

Related with ethics, for a humanistic perspective for STEM education it is necessary to address several features. Among them, profitability. As Pleasants et al. (2019) highlight, "technologies exist in an economic context, which means that profitability is often an end that is actively pursued during 
technological development, sometimes at the expense of the other goals" (p. 579). Also, technology and engineering shift from the classical image of science as a value-free enterprise: technoscientific products of knowledge are explicitly value-laden —of epistemic, economic, socio-political and ethical values(Vincent \& Loeve, 2018). Values are frequently in conflict, demanding assessment and regulation.

On the issue of social values, a common feature of all disciplines within STEM is that they are affected by and they affect cultural norms and societal needs. Moving away from commonplace extreme positions related to the influence of technology in the changes in society (either that technology determines changes or that humans freely direct technological development, see Pleasants et al., 2019), a NOSTEM should seek a temperate position, grounded on moderate realism and rationalism, which considers that technological systems are both socially constructed and society constructing (Hughes, 2012). That is, new technologies developed in —and shaped by - a particular social context make possible certain types of social changes, which can be positive, negative or neutral.

We consider that in the social category should be included the notion of responsible research and innovation. Innovation is a key element in the seamless web, and an inherent characteristic of the activities that are performed in science, technology, engineering and mathematics. It is worth noting that the concept of innovation - what innovation is, how it works and what its implications are-, a universal topic in official reports and recommendations, remains fuzzy, not only in science and technology education, but unclear for general audiences. Developing an epistemological understanding of the concepts of technology and innovation as part of human evolution is a prerequisite for educating students to overcome simplistic and widespread assumptions about the relationship between science, technology and innovation -i.e. science as the driving force of progress, technological determinism, innovation as something essentially good, etc.- (EdwardsSchachter \& Greca, 2017). This kind of philosophical discussion is also needed in order to challenge selective histories of specific technologies that ignore the impact of structural, social, economic, political, and psychological adjustments that were necessary to support their implementation (Volti, 2014). Integrated STEM education opens an opportunity to debate these aspects for developing genuinely responsible literacy. 
The features of the last categories of the FRA model are much less defined in the literature. In the dimension of the social organisation and interactions, it might be addressed the characteristics of big science and the different structures that are being proposed, as well as the recent trend in citizen science —or "crowd science" - and the growth of user-driven and user-led innovation. In these contexts, citizens may co-create scientific and technological knowledge or actively participate as innovators in the development of new products and services (von Hippel, 2005). Finally, NOSTEM should address the underlying financial dimensions, including the ways in which the ethical, social and political configuration of economy shapes the seamless web of STEM (Birch, 2013).

Following Kaya and Erduran's (2016) example, Table 4.1 synthetises the features that we have compared from a FRA for our proposal for NOSTEM. 
Table 4.1. Some features for a FRA model for NOSTEM

\begin{tabular}{|c|c|}
\hline $\begin{array}{l}\text { Seamless web of the four } \\
\text { STEM disciplines as a } \\
\text { cognitive-epistemic system }\end{array}$ & $\begin{array}{l}\text { Some features that might be } \\
\text { addressed }\end{array}$ \\
\hline Aims and values & $\begin{array}{l}\text { The responsible resolution of relevant } \\
\text { societal problems within a sustainability } \\
\text { matrix }\end{array}$ \\
\hline Methods & $\begin{array}{l}\text { Many shared methodologies } \\
\text { experimentation, modelling, design- } \\
\text { Design as a central methodology in } \\
\text { technoscientific research }\end{array}$ \\
\hline Knowledge produced & $\begin{array}{l}\text { Design of functional objects and } \\
\text { organisms } \\
\text { Proof-of-principle } \\
\text { Innovation }\end{array}$ \\
\hline Practices & $\begin{array}{l}\text { Closure } \\
\text { Validation }\end{array}$ \\
\hline
\end{tabular}

Seamless web of the four

STEM disciplines as a social-institutional system

Social certification and Scientists and mathematicians cannot in dissemination principle claim ownership of knowledge

The degree of expression -or codification - of technological knowledge may be largely due to socio-economic circumstances

Scientific ethos Products of knowledge are explicitly value-laden —epistemic, economic, sociopolitical and ethical-

Values are frequently in conflict and demand assessment and regulation

\begin{tabular}{ccc}
\hline Social values & $\begin{array}{c}\text { Technological systems are both socially } \\
\text { constructed and society shaping } \\
\text { Sustainability and responsible research } \\
\text { and innovation }\end{array}$ \\
\hline Social organizations and & $\begin{array}{l}\text { Big science } \\
\text { Crowd science }\end{array}$ \\
\hline Finteractions & $\begin{array}{l}\text { The ethical, social and political } \\
\text { configuration of economy configures and } \\
\text { shapes the seamless web. }\end{array}$ \\
\hline
\end{tabular}


The features that we reviewed here, as well as many others that would emerge from now on, cannot and must not be reduced to a set of declarative statements for teaching; rather, they should constitute themes to become engaged with and to elaborate on (Matthews, 2012). It is worth stressing that a humanist approach to STEM implies assuming from the very beginning that STEM-derived knowledge is one among many other ways of knowing (Chesky \& Wolfmeyer, 2015), but at the same time recognising that, in our Western societies, a poor understanding of the conceptual products of STEM will certainly be detrimental for the exercise of full citizenship.

The adoption of an epistemological framework constructed highlighting the family resemblances between the four constituent disciplines does not imply neglecting the specific features of each type of knowledge for teaching. Following the example given by Williams (2011), the relevance of the technological knowledge needed for solving a problem is defined by the very nature of the problem, because the pursuit of the solution determines the information that is needed. The knowledge needed to solve an engineering problem is somehow pre-defined by the context - electrical, chemical, organisational, sanitary, etc. - and so, it is not as dependent on the nature of the design problem. Technology contexts are less associated with a defined body of knowledge than engineering; accordingly, when we "enter" STEM through engineering, students have less space to explore and define "new", "creative" knowledge.

\subsection{As a conclusion}

When approaching STEM as an emerging construct that is gaining momentum in our academic community, meta-analyses, theoretical studies, sound argumentation, and reflection from philosophy are necessary, since all of these offer a better conceptual comprehension and allow deeper understanding of the scope and limits of empirical research and practical proposals. Conceptual approaches to the discussion of STEM help establish a set of humanist aims for meaningful education (Gil Cantero \& Reyero, 2014).

The available philosophical views on integrated STEM education are still very incipient, with most of its epistemological aspects absent or blurred. In order for STEM to develop, we must discuss these issues without reluctance. 
In this paper, we state that renewed approaches to science education should pursue the integral formation of people with the aim of achieving full citizenship, and that this should be done from very early stages. Thus, integrated STEM education should remain committed to what we have called a humanist approach, identified with sound reasoning, argumentation, criticism, participation and responsible action (Zeidler \& Sadler, 2007). If every epistemological stance has an underlying axiology, we think that it is relevant to adjust our philosophical position to the educational aims that society currently supports; this could be called an ad-hoc epistemology for school science.

On the basis of a reflection on the diversity of philosophical views in the late $20^{\text {th }}$ century and of axiological considerations, we want to move away in this paper from a technocratic and economy-driven perspective on STEM, which highlights intra-national economic and utilitarian intentions as well as reveres technological supremacy (Clough et al., 2013). Such perspective was behind the creation of the acronym, and is still perpetuated in many educational settings.

After revisiting the current relationships between the knowledge produced in science, technology, engineering and mathematics, we adopted a "seamless web" model for these relationships, which seems to be coherent with the educational aims of STEM that we envisage. Issues emerging from our view on STEM were addressed through the lens of the FRA approach in order to obtain some potential features for a NOSTEM.

Our adoption of a particular set of epistemological views shapes issues as relevant as the construction of national and local curricula or the choice of classroom pedagogies. In the same way, epistemological assumptions can have direct impact on the way knowledge is transmitted and, therefore, on the construction of knowledge by students and on their ways of understanding the world and acting in it. Therefore, within an inclusive and equitable perspective for STEM, it is important to introduce epistemic "heterogeneity" in our pragmatic approach, given that knowledge systems, including science, are not objective or natural, but socially and ideologically constructed (Harding, 1991). Such pragmatism in the choice of epistemologies should of course be done in a way that seeks coherence with our proclaimed aims and values and avoids philosophical contradiction or inconsistency. An example in this direction of selecting appropriate epistemological foundations would be to resort to the work on "engineering for sustainable communities", developed by Tan, 
Calabrese Barton and Benavides (2019), which would imply expanding the epistemological constructs that we use for STEM far beyond the "canonical" epistemologies.

A humanist approach to science education would not focus on the development of scientific vocations, but these will naturally arise, a point that has already been detected (Maltese \& Tai, 2010). It is our contention that an educational approach should not be subordinated to economic directions, but should rather aim at developing the range of skills necessary for students to achieve full citizenship in the society in which they live (UNESCO, 2016). Integrated STEM curriculum and teaching should put social and cultural meaning first, aiming at social justice through technoscientific literacy. Thus, the intention of this paper is to contribute with a few initial elements to understand the implications that adopting some or other epistemological view on the four STEM disciplines and on their integration will have on general educational for all and on the construction of society as a whole 


\section{SEGUNDA PARTE}

Diseño e implementación de la unidad didáctica 

Propuesta de la unidad didáctica STEAM integrada: la iluminación de mi sala de estudio 

$\mathrm{E}$ n este capítulo se describe la fase aplicada o práctica de la tesis doctoral, que cotempla el diseño y el modo de implementación de la UD enmarcada en la educación STEAM integrada. Para ello, se expone una introducción justificativa de la UD y se muestra la demarcación de los contenidos abordados, así como una relación de los objetivos didácticos de la propuesta. A continuación, se presenta detalladamente la secuencia seguida en el proceso de enseñanza-aprendizaje y se proponen algunas posibles adaptaciones para la aplicación de la UD en otros contextos o situaciones educativas. Por último, se comentan ciertas cuestiones relacionadas con la evaluación y se realizan algunas consideraciones finales alrededor de la propuesta.

La propuesta fue diseñada teniendo en consideración los principios expuestos en el Capítulo 3 sobre la fundamentación teórica, basados en la red triádica laudaniana, representada en la Figura 5.1.

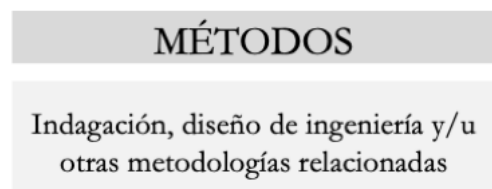

\section{TEORÍAS}

- Eje epistemológico (Laudan, 1977)

- Eje psicológico (Vergnaud,1990)

- Eje didáctico (Martinand, 1986)

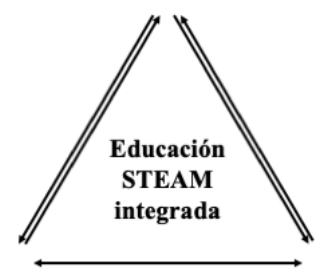

\section{OBJETIVOS}

Potenciar el desarrollo competencial del alumnado

Figura 5.1. Modelo de funcionamiento triádico para el encuadre teórico de la educación STEAM integrada.

Así, en armonía con el fin de potenciar el desarrollo competencial del alumnado y, en consonancia con lo propuesto por Martinand, los objetivos de la UD derivaron a considerar los objetivos-representación a ser superados como ejes a partir de los cuales seleccionar las estrategias didácticas y los contenidos a abordar. Para ello, se revisaron las concepciones alternativas catalogadas en la literatura sobre los potenciales contenidos que se trabajarían 
en las áreas de Ciencias de la Naturaleza, Matemáticas y Educación Plástica. Algunos ejemplos se pueden consultar en el Anexo 5.1. Se seleccionaron así una serie de representaciones que no se correspondían con lo científicamente consensuado y que fueran abordables en el limitado periodo de tiempo en el que se desarrollaría la UD. Así mismo, se generaron situaciones variadas y encaminadas a la fisura de las representaciones escogidas y, en consonancia con la teoría psicológica de Vergnaud, estas situaciones ofrecieron al alumnado la oportunidad de enfrentarse a los conceptos-en-acción y teoremas-en-acción repetidamente, así como al uso de diferentes representaciones, lo que le permitió enriquecer sus esquemas mentales y, con ello, mejorar su desarrollo competencial. Cabe destacar que, al adoptar la propuesta epistemológica de Laudan, toda la UD giró en torno a la resolución de un problema científico escolar.

Dado que, según esta fundamentación, las teorías limitan las metodologías didácticas a emplear, y que estas son justificadas por los fines, fueron escogidas dos metodologías: la indagación en su versión guiada (MartinHansen, 2002) y el diseño de ingeniería. Ambas permiten que el alumnado se enfrente a situaciones variadas, con diferentes representaciones, favoreciendo su desarrollo competencial en el sentido amplio que se ha adoptado - es decir, en las siete dimensiones indicadas en el Capítulo 2-, además de resultar altamente motivadoras (Greca, 2018).

El modelo transdisciplinario creado, combinando ambas metodologías didácticas y las diferentes áreas STEAM abordadas, se representa en la Figura 5.2. Una discusión ampliada de esta fundamentación para la UD aparece en el material complementario del Capítulo 3 — sección 3.7-. 


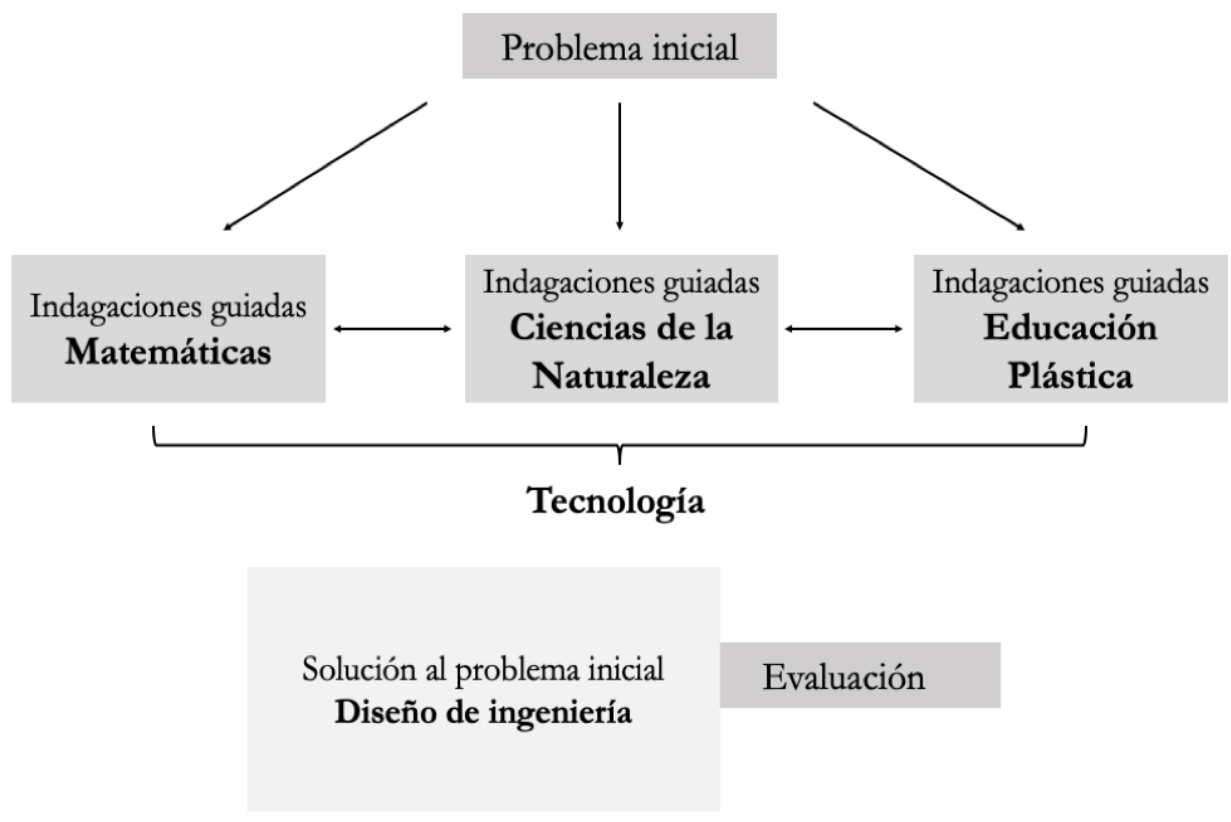

Figura 5.2. Modelo transdisciplinario para la educación STEAM integrada.

Cabe destacar que en esta UD no se abordaron de forma explícita elementos de la NOTSTEM indicados en el Capítulo 4, dado que en el momento de su diseño e implementación aún no se había avanzado lo suficiente en su conceptualización.

Indicar que la mayoría de la información que se presenta en este capítulo procede de un trabajo preliminar (Ortiz-Revilla, 2018). Por ello, aunque se ha considerado adecuado presentar el capítulo manteniendo la estructura del trabajo publicado con el título «¿Cómo diseñar un prototipo de iluminación para mi sala de estudio?», en algunas ocasiones se ha añadido información adicional. También se han omitido los dos últimos apartados de la publicación original, por desarrollarse más detalladamente en los sucesivos capítulos de esta tesis doctoral, y las referencias bibliográficas, que se presentan compiladas en el Capítulo 9. 


\subsection{Introducción}

Los asuntos asociados al estudio del tópico de la electricidad — foco de la presente UD y contenido vigente en todos los currículos educativos- parecen particularmente aptos para ser abordados a través de enfoques educativos que, además de la asignatura de Ciencias de la Naturaleza, engloben otras disciplinas.

Por una parte, gran variedad de cuestiones relacionadas con este campo atañe a diversas circunstancias cotidianas, concibiéndose más factible el planteamiento de problemas o de situaciones problemáticas potencialmente interesantes para el alumnado y permitiendo formular preguntas investigables más concretas y de mayor relevancia. Por otro lado, resulta amplia la posibilidad que ofrece de realizar experiencias empíricas viables, ya que en la mayoría de los experimentos pueden ser utilizados materiales de bajo costo y fácil acceso. Además, es necesario destacar la particular importancia de abordar didácticamente y desde edades tempranas contenidos de esta índole, dada su inmersión en campos conceptuales en los que modificar las concepciones alternativas del alumnado resulta especialmente dificultoso.

Para ello, se hace necesario acudir a los conocimientos científicos presentes en la literatura especializada. Las concepciones o ideas alternativas más habituales que los escolares suelen poseer sobre la electricidad están relacionadas con la concepción de esta como una especie de fluido que «sale» de un almacén que es la pila y que circula a lo largo de unos tubos, aludiendo a los cables (Arillo et al., 2013). Algunas afirmaciones realizadas por escolares como «la pila se ha gastado, ya no tiene electricidad», o algunos métodos de intentar hacer lucir una bombilla sin asegurarse de mantener el circuito cerrado son pruebas evidentes de ello. Asimismo, explicaciones del concepto de electricidad como un fluido se siguen detectando en estudiantes universitarios (Guisasola, Zubimendi, Almudí y Ceberio, 2008), lo que permite hacernos una idea de la dificultad que supone su aprendizaje.

Desde el ámbito de las matemáticas, el amplio campo de la estadística representa otro núcleo de vital importancia para los primeros años de la educación. A menudo, el alumnado presenta grandes dificultades en la contextualización de los datos, su reorganización o su representación visual, así como una creencia generalizada de que todos los tipos de gráficos que conoce pueden servir para representar todo aquello que se desee. Así, resulta 
imprescindible abordar tempranamente el tratamiento de datos, siempre en continua relación con situaciones presentes en el mundo actual, tanto para propiciar la aprehensión del propio contenido matemático como para poder dotar de significatividad y rigurosidad a los problemas científicos reales.

Habitualmente, las propuestas enmarcadas en este tipo de enfoques priorizan el estudio de aspectos relacionados con las áreas de Ciencias de la Naturaleza y Matemáticas. Por ello, quizás lo más novedoso de esta propuesta resida en la incorporación de determinados aspectos relacionados con el color, contenido propio del área de Educación Plástica desde el punto de vista curricular; currículo -el de Educación Plástica- presente en todos los niveles de la etapa de Educación Primaria, pero en muchos casos completamente olvidado.

Resulta común que el alumnado dote a la materia de la propiedad intrínseca del color, no advirtiendo la influencia de la luz en la percepción o asociándole cualidades erróneas. También, que explique el concepto de color asociado al de pigmento o viceversa y disociándolo de la luz. Como comprobaremos más adelante, la incorporación de contenidos de esta naturaleza no solo ayuda a que los fenómenos científicos presentes en la realidad del alumnado sean mejor comprendidos al tratarse de manera holística, sino que puede propiciar el desarrollo de la creatividad y de la imaginación al tiempo de un aprendizaje situado de los propios propósitos artísticos.

La siguiente propuesta se llevó a cabo dentro del sistema de educación formal español con alumnado de sexto de Educación Primaria —escolares entre los 11 y los 12 años - y en repetidas ocasiones (Ortiz-Revilla, Greca y Meneses Villagrá, 2019) lo que nos permite presentar aquí una unidad depurada con la que maestros bien podrían comenzar confiadamente su andadura en la enseñanza STEAM.

\subsection{Contenidos abordados a través del planteamiento STEAM}

La presente propuesta STEAM integrada fue implementada a través de un planteamiento transdisciplinario, trascendiendo las disciplinas individuales y ubicando el foco de interés en un campo de conocimiento relacionado con el mundo real (Gresnigt et al., 2014); en este caso, la iluminación de los espacios. 
A través de la metodología de indagación, partimos de una situación problemática real que emana de la proximidad a la ESO en la que se encuentra el alumnado de sexto de Educación Primaria —último año de este periodo educativo-. Es en la nueva etapa de estudios cuando aumentará considerablemente su carga de trabajo, por lo que, para conseguir un buen rendimiento, ha de apropiarse de un espacio de trabajo confortable.

Una de las características más importantes de ese espacio radica en su iluminación, ya que esta, al igual que la temperatura o el ruido constituye un factor muy influyente en el rendimiento mental (Mora, 2017). En esta contextualización presentamos el problema principal: ¿Cómo diseñar un prototipo de iluminación para mi sala de estudio?, sobre el cual se irá cimentando el estudio del alumnado a lo largo de toda la unidad y que quedará registrado en su cuaderno de campo.

El modelo que subyace a esta propuesta aborda expresamente y de manera integrada contenidos de tres asignaturas de la etapa de Educación Primaria, concretamente vinculados a las Ciencias de la Naturaleza, la Educación Plástica y las Matemáticas.

En la Tabla 5.1 se muestra una relación de los aspectos trabajados en cada una de las áreas según el enfoque educativo STEAM en vista de mejorar el desarrollo competencial del alumnado.

Tabla 5.1. Relación de los aspectos trabajados en cada disciplina STEAM

\begin{tabular}{lllll}
\hline \multicolumn{1}{c}{ Ciencia } & \multicolumn{1}{c}{ Tecnología } & \multicolumn{1}{c}{ Ingeniería } & \multicolumn{1}{c}{ Arte } & Matemáticas \\
\hline El problema & Empleando las & Enfocándose & Indagando & Realizando un \\
central & Tecnologías de & en torno al & acerca de & tratamiento de \\
afronta & la Información y & diseño de un & cuestiones & diferentes \\
contenidos & la & prototipo & relacionadas & datos \\
relacionados & Comunicación, & siguiendo las & con el color & matemáticos a \\
con el & así como & fases del & y sus & través de \\
campo de la & abordando & diseño de & sensaciones. & variables, \\
electricidad. & aspectos & ingeniería. & & tablas y \\
& tecnológicos & & & gráficos. \\
& ligados al & & & \\
& mundo de la & & & \\
& iluminación y & & & \\
& sus avances. & & & \\
\hline
\end{tabular}


Como apunte, y aunque aquí no se explicitan, esta unidad ofrece la posibilidad de incluir algunas sesiones más para abordar contenidos relacionados con el magnetismo, dada su relación con la electricidad.

Aunque es la indagación la metodología específica utilizada para llevar a cabo la propuesta STEAM, en esta ocasión no formulamos hipótesis al uso sobre el problema principal sino que, tanto en esta fase indagatoria como en el resto - formulación de predicciones, realización de experimentos, análisis de datos y evidencias, comunicación de resultados y conclusiones-, trabajamos desde otros problemas de dimensión más reducida —más abordables, más investigables - derivados de cada campo de conocimiento abordado.

En aras de proponer a todo lector un encuadre comprensible de los contenidos tratados en esta unidad, además de recopilar los contenidos curriculares oficiales mediante los cuales se realizó la programación (Anexo 5.2), se presenta una demarcación en otra taxonomía más abarcadora y de carácter internacional.

Dentro de la clasificación de las denominadas Big Ideas o catorce ideas clave esenciales que todo estudiante debería comprender en su educación científica durante los años obligatorios en la escuela para poder entender, disfrutar y maravillarse del mundo natural (Harlen, 2015), esta propuesta se sumerge, de manera más o menos profunda, en las siguientes:

\section{Ideas cientificas}

- Toda la materia en el Universo está compuesta de partículas muy pequeñas.

- Los objetos pueden afectar a otros objetos a distancia.

- Cambiar el movimiento de un objeto requiere una fuerza neta para actuar sobre él.

- La cantidad total de energía en el Universo es siempre la misma, pero puede ser transferida de un almacén de energía a otro durante un evento.

\section{Ideas sobre Ciencias}

- La ciencia trata de encontrar la causa de los fenómenos en el mundo natural. 
- Las explicaciones, teorías y modelos científicos son los que mejor se ajustan a la evidencia disponible en un momento determinado.

- El conocimiento producido por la ciencia se usa en ingeniería y tecnología para crear productos que sirven a los fines humanos.

En síntesis, con el desarrollo de esta unidad pretendemos que el alumnado consiga comprender el fenómeno de la corriente eléctrica como un movimiento continuo de cargas eléctricas inmersas dentro de un circuito cerrado que puede estar compuesto de diferentes componentes y que, entre sus numerosos usos en el mundo real, está el de producir luz.

Asimismo, partiendo de este núcleo de conocimiento fundamental, practicamos el ejercicio del tratamiento de datos mediante diferentes tipos de gráficos, para así contribuir a allanar el camino hacia la desmitificación de la polivalencia de estos en la representación de datos. De la misma manera, aspiramos a que el alumnado pueda construir explicaciones con una noción conceptual de color que englobe la influencia de la luz y no disocie los conceptos de pigmento y luz; por ejemplo, que el color no es una propiedad intrínseca de la materia sino una sensación producto de la interacción entre la luz, el material de los objetos sobre los que incide y la percepción de los órganos visuales. Estos conocimientos, a su vez, pueden facilitar el desarrollo de procesos artísticos como la creación de composiciones con el color, usando las gamas cromáticas más adecuadas según la psicología del color y las sensaciones que se deseen transmitir.

Con el objetivo de clarificar todo lo expuesto, en la figura 5.3 se muestra un mapa conceptual que encuadra estas explicaciones científicas dentro de la red de contenidos abordados en la unidad. 


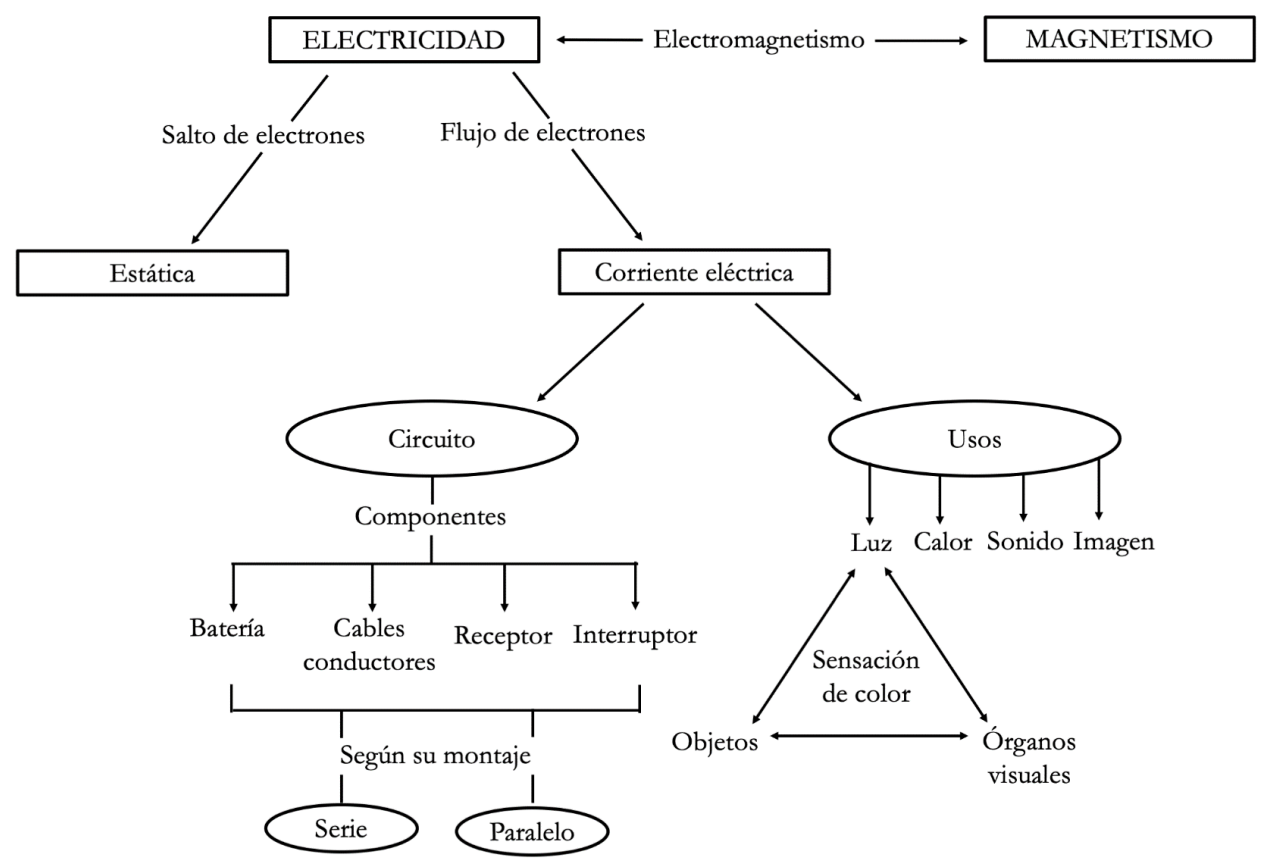

Figura 5.3. Mapa conceptual de los contenidos abordados a lo largo de la UD.

\subsection{Objetivos de la propuesta didáctica}

Aunque la programación contempla un mayor número de objetivos, consideramos que al finalizar la UD el alumnado ha de ser principalmente capaz de llevar a cabo las siguientes tareas de (ver Tabla 5.2):

Tabla 5.2. Objetivos principales de la propuesta divididos por disciplinas escolares

\section{Ciencias de la Naturaleza}

- Buscar, seleccionar y organizar información concreta y relevante, analizarla, obtener conclusiones, comunicar su experiencia, reflexionar acerca del proceso seguido y comunicarlo oralmente y por escrito.

- Realizar experiencias sencillas y pequeñas investigaciones, planteando problemas, enunciando hipótesis, seleccionando el material necesario, extrayendo conclusiones, y comunicando los resultados.

- Identificar y explicar algunos efectos de la electricidad.

- Explicar algunos de los avances de la ciencia en el hogar y la vida cotidiana. 


\section{Matemáticas}

- Identificar e interpretar datos, realizar tablas y utilizar diferentes gráficos para su representación, con información obtenida en su entorno.

- Realizar análisis críticos y argumentados sobre las informaciones que se presentan mediante gráficos estadísticos.

\section{Educación Plástica}

- Aplicar el conocimiento de la simbología de los colores fríos y cálidos para transmitir diferentes sensaciones en las composiciones plásticas que realiza.

\subsection{Secuencia de enseñanza}

Aunque ya sabemos que el enfoque educativo STEAM aborda diversas áreas de manera integrada, existen algunos aspectos con un mayor anclaje disciplinar. En la Tabla 5.3 se muestra un esquema general del número de sesiones llevadas a cabo a lo largo de la propuesta didáctica completa y se aporta una explicación general de las actividades realizadas según la disciplina desde la que parten. 
Tabla 5.3. Relación y explicación general de las sesiones

\begin{tabular}{|c|c|c|c|}
\hline Sesión & \multicolumn{2}{|c|}{ Ciencia } & Ingeniería \\
\hline 1 & \multicolumn{2}{|c|}{$\begin{array}{c}\text { Presentación de problemas } \\
\text { científicos y formas de resolución }\end{array}$} & $\begin{array}{l}\text { Presentación de problemas de ingeniería y } \\
\text { formas de resolución }\end{array}$ \\
\hline 2 & \multicolumn{2}{|c|}{$\begin{array}{l}\text { Debate de ideas previas sobre la } \\
\text { electricidad, introducción del } \\
\text { contenido de la electricidad } \\
\text { estática y realización de } \\
\text { experimentos relacionados con la } \\
\text { electricidad estática }\end{array}$} & \\
\hline 3 & \multicolumn{2}{|c|}{$\begin{array}{c}\text { Construcción de la explicación } \\
\text { científica sobre la electricidad } \\
\text { estática y síntesis de las ideas } \\
\text { clave }\end{array}$} & \\
\hline \multirow[t]{2}{*}{4} & \multicolumn{2}{|c|}{$\begin{array}{l}\text { Inmersión en el concepto de } \\
\text { circuito y búsqueda de } \\
\text { información sobre cómo se } \\
\text { produce la corriente eléctrica }\end{array}$} & \\
\hline & Ciencia & Tecnología & Matemáticas \\
\hline 5 & $\begin{array}{l}\text { Construcción de } \\
\text { la explicación } \\
\text { científica sobre la } \\
\text { corriente eléctrica } \\
\text { y síntesis de las } \\
\text { ideas clave }\end{array}$ & $\begin{array}{l}\text { Conversación } \\
\text { acerca de los } \\
\text { diferentes } \\
\text { usos que } \\
\text { pueden darse } \\
\text { a la corriente } \\
\text { eléctrica }\end{array}$ & \\
\hline \multirow[t]{2}{*}{6} & $\begin{array}{c}\text { Debate de ideas } \\
\text { previas sobre las } \\
\text { bombillas }\end{array}$ & $\begin{array}{l}\text { Conversación } \\
\text { acerca de los } \\
\text { diferentes } \\
\text { tipos de } \\
\text { bombillas en } \\
\text { cuanto a su } \\
\text { consumo, } \\
\text { durabilidad, } \\
\text { etc. }\end{array}$ & \multirow[t]{2}{*}{$\begin{array}{l}\text { Recopilación de datos sobre el consumo de } \\
\text { electricidad, el precio y las horas de vida de } \\
\text { algunos tipos de bombillas en una tabla de } \\
\text { variables cualitativas y cuantitativas }\end{array}$} \\
\hline & $\begin{array}{r}\text { Indagación con di } \\
\text { bombi }\end{array}$ & $\begin{array}{l}\text { tlintos tipos de } \\
\text { llas }\end{array}$ & \\
\hline
\end{tabular}




\begin{tabular}{|c|c|c|c|}
\hline 7 & $\begin{array}{l}\text { Debate sobre la rentabilidad de } \\
\text { las bombillas }\end{array}$ & \multicolumn{2}{|c|}{$\begin{array}{l}\text { Construcción de gráficos de barras de cada } \\
\text { variable registrada, reflexión sobre su función } \\
\text { y cálculo de la bombilla más rentable }\end{array}$} \\
\hline 8 & $\begin{array}{l}\text { Reflexión acerca } \\
\text { de la relación } \\
\text { entre el consumo } \\
\text { y el coste de la } \\
\text { electricidad }\end{array}$ & \multicolumn{2}{|c|}{$\begin{array}{l}\text { Conocimiento de la unidad } \mathrm{kWh} \text {, relacionada } \\
\text { con la unidad W, construcción de gráficos } \\
\text { poligonales y reflexión sobre su función }\end{array}$} \\
\hline 9 & & \multicolumn{2}{|c|}{$\begin{array}{c}\text { Recuento de bombillas, construcción de } \\
\text { gráficos sectoriales y agrupación de datos en } \\
\text { tablas }\end{array}$} \\
\hline 10 & $\begin{array}{l}\text { Reflexión individual y grupal } \\
\text { acerca del ahorro de energía en } \\
\text { relación con la sustitución de } \\
\text { determinados tipos de bombillas }\end{array}$ & \multicolumn{2}{|c|}{$\begin{array}{c}\text { Construcción de gráficos sectoriales con datos } \\
\text { de tablas y manejo del porcentaje }\end{array}$} \\
\hline & Ciencia $\quad$ Tecnología & \multicolumn{2}{|l|}{ Arte } \\
\hline 11 & $\begin{array}{l}\text { Experimentación } \\
\text { con la luz y el } \\
\text { color, reflexión y } \\
\text { conclusiones }\end{array}$ & \multicolumn{2}{|c|}{$\begin{array}{l}\text { Debate de ideas previas sobre el color, } \\
\text { experimentación con luz y color, reflexión y } \\
\text { conclusiones }\end{array}$} \\
\hline 12 & & \multicolumn{2}{|c|}{$\begin{array}{c}\text { Composición artística de colores cálidos y } \\
\text { fríos }\end{array}$} \\
\hline & Tecnología & Ingeniería & Matemáticas \\
\hline 13 & $\begin{array}{l}\text { Conocimiento de } \\
\text { la simbología } \\
\text { científica } \\
\text { relacionada con } \\
\text { la electricidad }\end{array}$ & $\begin{array}{cc}\text { Requisitos y } & \text { Diseño del } \\
\text { prototipo } \\
\text { especificaciones } & \text { cuidando la } \\
\text { para llevar a } & \text { simbología } \\
\text { cabo el diseño } & \text { científica, } \\
\text { de ingeniería y } & \text { el } \\
\text { puesta en } & \text { significado } \\
\text { marcha del } & \text { del color, } \\
\text { diseño } & \text { la escala, } \\
& \text { etc. }\end{array}$ & $\begin{array}{c}\text { Consideración } \\
\text { de la } \\
\text { rentabilidad } \\
\text { del prototipo } \\
\text { según las } \\
\text { variables } \\
\text { estudiadas y } \\
\text { manejo de la } \\
\text { escala en el } \\
\text { diseño }\end{array}$ \\
\hline $\begin{array}{c}14 \mathrm{y} \\
15\end{array}$ & \multicolumn{3}{|c|}{ Preparación de las presentaciones } \\
\hline \multirow[t]{2}{*}{16} & & $\begin{array}{cc}\text { Aplicación de } & \text { Dibujo del } \\
\text { mejoras en el } & \text { prototipo } \\
\text { diseño } & \text { final }\end{array}$ & $\begin{array}{l}\text { Manejo de la } \\
\text { escala en el } \\
\text { dibujo del } \\
\text { prototipo final }\end{array}$ \\
\hline & & Inicación de datos & \\
\hline
\end{tabular}


Antes de presentar la secuenciación es necesario aclarar que, para el desarrollo de cada una de las sesiones, se consumió una media de 50 minutos.

\section{SESIÓN 1:}

- Presentación de problemas reales en ciencia e ingeniería y formas de resolución:

La primera sesión comienza con la introducción de un problema que abarca a la ciencia y la ingeniería como es la construcción de un puente. El objetivo es provocar la reflexión del alumnado acerca de lo que subyace a cualquier problema real. Por ejemplo, en este problema planteamos si la obra de construcción de un puente se realiza en un lugar determinado nada más detectar su necesidad o si por el contrario se precisa realizar alguna acción previa antes de la puesta en marcha. El alumnado aporta ideas de lo que cree que ha de suceder antes de la construcción y termina comprendiendo que existe una serie de estudios científicos, una fase de realización de proyectos, bocetos, etc. que se deben llevar a cabo previamente a esta.

Recuerda: Otros problemas reales y abarcadores de ambas disciplinas podrían ser de igual validez para ilustrar esta toma de contacto. Por ejemplo, la construcción de un barco o el desarrollo de una planta potabilizadora de agua.

- Conexión con la explicación de la metodología de trabajo y planteamiento del problema principal:

Aprovechamos la introducción anterior para encadenar una breve explicación de la metodología de trabajo que el alumnado tendrá que seguir para resolver su problema principal: ¿Cómo diseñar un prototipo de iluminación para mi sala de estudio? El problema ha de contextualizarse para que se apropien de él y le otorguen un sentido, cuestiones que aumentarán su motivación. En este caso explicamos la situación de necesidad que el mismo alumnado tiene de poseer un espacio adecuado para el estudio de cara a su inminente entrada en la etapa de la ESO. Después se aclara que, al igual que en el ejemplo del puente, ellos tendrán que trabajar en grupo y apropiarse de una serie de conocimientos antes de realizar su diseño final. 


\section{SESIÓN 2:}

- ¿Cómo hacemos funcionar nuestra instalación? Debate breve de ideas previas sobre la electricidad:

Retomando lo acordado en la anterior sesión, comenzamos con los estudios previos imprescindibles para el posterior diseño de su prototipo de iluminación. Planteamos la pregunta «¿cómo va a funcionar nuestra instalación?» para hacer aparecer el concepto de electricidad. A partir de ahí, recogemos en la pizarra las ideas previas que posee el alumnado sobre este tópico. Para fomentar la participación, se pueden hacer preguntas como: ¿qué es la electricidad?, ¿cómo se genera?, ¿para qué sirve?, etc.

\section{- Introducción del contenido de la electricidad estática:}

Siguiendo el discurso comenzado en las ideas previas, introducimos el contenido de la electricidad estática a través del concepto de electrón. En este caso, la introducción debe iniciarse por una aproximación al modelo atómico y sus diferentes componentes para después aproximarse al electrón y explicar la manera en que interviene en este fenómeno.

\section{- Realización de experimentos relacionados con la electricidad estática:}

Una vez introducido el contenido principal, continuamos con la fase de indagación. Los alumnos frotan globos de plástico con su propio pelo, su ropa o una bayeta de microfibras para después intentar erizar su pelo o el de otros compañeros, atraer virutas de papel y porexpan, transportar latas de metal y atraer el fino chorro de agua de un grifo. Por último, realizamos un último experimento en el que se cargan dos globos atados a una percha y comprobamos el efecto de repulsión. En el Anexo 5.3 se puede consultar, en tres ejemplos de cuaderno de campo ya completados, la ficha con la que el alumnado trabaja estas indagaciones. En la Figura 5.4 se ve como los estudiantes realizan experimentos sobre electricidad estática. 


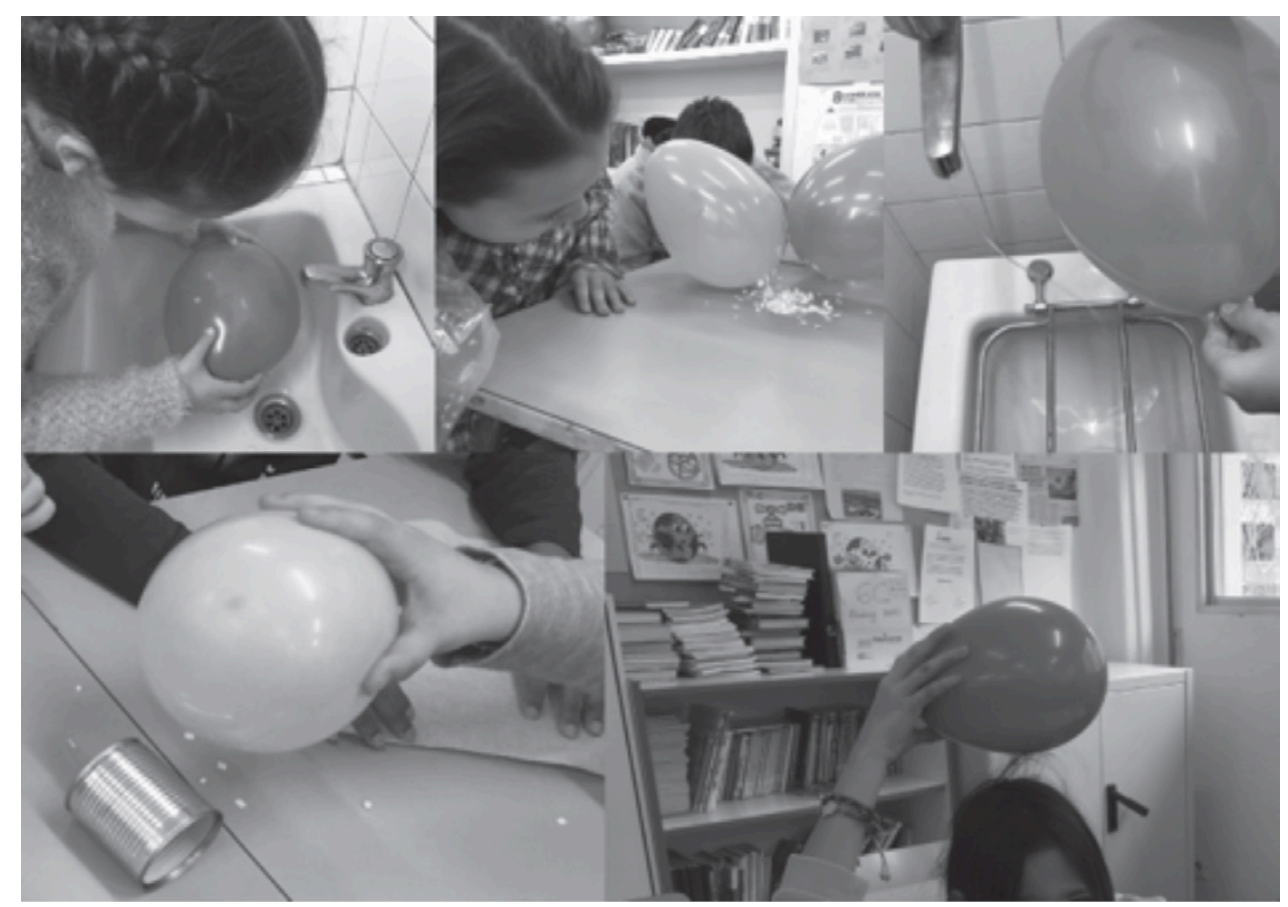

Figura 5.4. Algunos experimentos con electricidad estática realizados por el alumnado.

\section{SESIÓN 3:}

- Construcción de la explicación cientifica sobre la electricidad estática:

Una vez realizada la parte experimental, procedemos en gran grupo a construir una explicación científica de todo lo ocurrido. Recordamos brevemente los asuntos relacionados con la constitución de la materia modelo atómico- con sus cargas eléctricas positivas — protones-, negativas -electrones-y neutras - neutrones-. Después, generamos conclusiones de los efectos que puede producir el frotamiento en los objetos neutros -estado normal de la materia, mismo número de protones que de electrones-, para finalizar dando sentido a la atracción o repulsión que se producía en los experimentos. Por último, dialogamos acerca de las manifestaciones de la electricidad estática en los hechos de la vida real. Por ejemplo, se puede explicar este fenómeno a través de los rayos, del sonido que oímos al quitarnos un jersey de lana o el calambre que a veces sentimos al salir de los coches. 
- Sintesis de las ideas clave:

Para concluir con el tratamiento de la electricidad estática proponemos que el alumnado realice como deberes un resumen, un esquema o un mapa conceptual de lo estudiado en las sesiones anteriores.

Recuerda: Esta actividad también se podría realizar más guiada en una sesión adicional presencial.

\section{SESIÓN 4:}

- ¿Cómo construimos nuestra instalación eléctrica? Inmersión en el concepto de circuito:

Siguiendo con el estudio de los contenidos de la unidad, introducimos el otro tipo de electricidad, la corriente eléctrica. Al ya haber sido trabajadas las ideas previas del alumnado en sesiones anteriores, en este caso partimos de una serie de experimentos para dar a conocer el concepto de circuito. Los escolares han de hacer lucir una bombilla sin más aparatos que una pila de petaca de 4,5V para después ir incorporando dos cables, probar con otra pila de más voltaje $(9 \mathrm{~V})$, interponer diferentes materiales conductores y aislantes en el circuito que han creado, así como un pulsador, un zumbador y un pequeño motor (ver Figura 5.5). Durante la parte experimental de esta indagación, además, construyen los dos tipos diferentes de circuitos - en serie y en paralelo- y conocen algunas de sus características, por ejemplo, lo que ocurre en cada uno de ellos cuando se desenrosca una de sus bombillas. En el Anexo 5.3 se puede consultar la ficha con la que el alumnado trabaja en esta actividad.

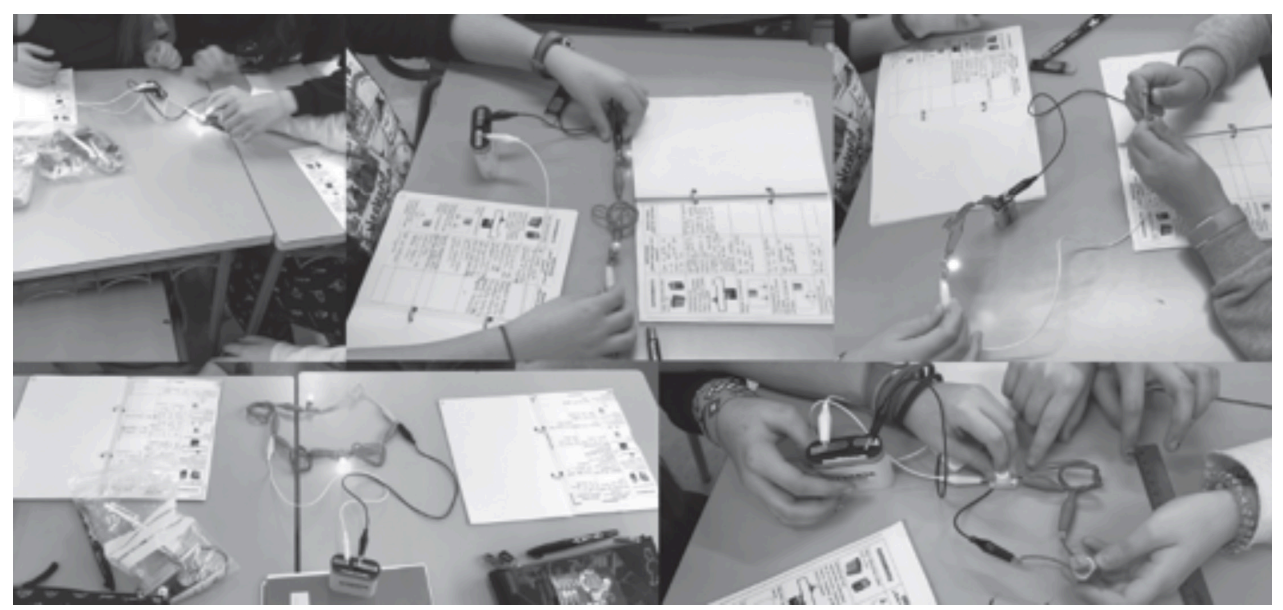

Figura 5.5. Algunos experimentos con circuitos realizados por el alumnado. 
- Búsqueda de información:

Con el fin de preparar al alumnado para la siguiente construcción de la explicación científica, encomendamos como deberes la búsqueda de información acerca de la manera en que se produce la corriente eléctrica. En este tipo de actividades es conveniente proporcionar alguna pauta o premisa sencilla que facilite y a la vez haga más significativo su trabajo, por ejemplo, aclarar que solamente deben recopilar información que ellos entiendan para poder aportar una futura explicación.

Recuerda: También podemos hacer eco de dudas generadas durante la búsqueda.

\section{SESIÓN 5:}

- Construcción de la explicación cientifica sobre la corriente eléctrica:

Con la base experimental trabajada y con la ayuda de la información recopilada anteriormente, procedemos a construir en gran grupo la explicación científica del contenido. Guiamos esta construcción para dar a conocer el funcionamiento de la corriente eléctrica, el concepto de energía y su transformación, los elementos que posee un circuito y los materiales conductores y aislantes. Por último, conversamos acerca de los diferentes usos que pueden darse a la corriente eléctrica: luz, imagen, sonido, calor, movimiento, comunicación, etc., así como de sus manifestaciones en situaciones de la vida real. Por ejemplo, el hecho de que se funda una bombilla en un árbol de Navidad puede implicar que no funcione ninguna de las bombillas de ese mismo color, al estar generalmente montadas en serie.

\section{- Sintesis de las ideas clave:}

Al igual que con la electricidad estática, también concluimos el tratamiento de la corriente eléctrica proponiendo al alumnado la realización como deberes de un resumen, un esquema o un mapa conceptual basado en lo estudiado anteriormente. 


\section{SESIÓN 6:}

- ¿Qué tipo de bombilla utilizamos en nuestro prototipo? Debate breve de ideas previas sobre las bombillas:

Al comenzar con el tratamiento de un nuevo contenido recogemos en la pizarra las ideas previas del alumnado con respecto a las bombillas. Con el objetivo de aumentar la participación, se pueden formular algunas preguntas, por ejemplo: ¿son todas las bombillas iguales? Así se puede abrir un debate en el que suelen aparecer conceptos clave como el consumo, la durabilidad o el color.

\section{- Indagación con distintos tipos de bombillas:}

En esta actividad llevamos a cabo una recopilación de datos sobre el consumo de electricidad, el precio y las horas de vida que tienen algunos tipos de bombillas: incandescente, halógena, bajo consumo y led (ver Figura 5.6). Para ello, dotamos a cada grupo de cuatro cajas con sus respectivas bombillas en las que aparece toda la información necesaria que es recogida por los escolares en una tabla de variables cualitativas y cuantitativas (Anexo 5.3).

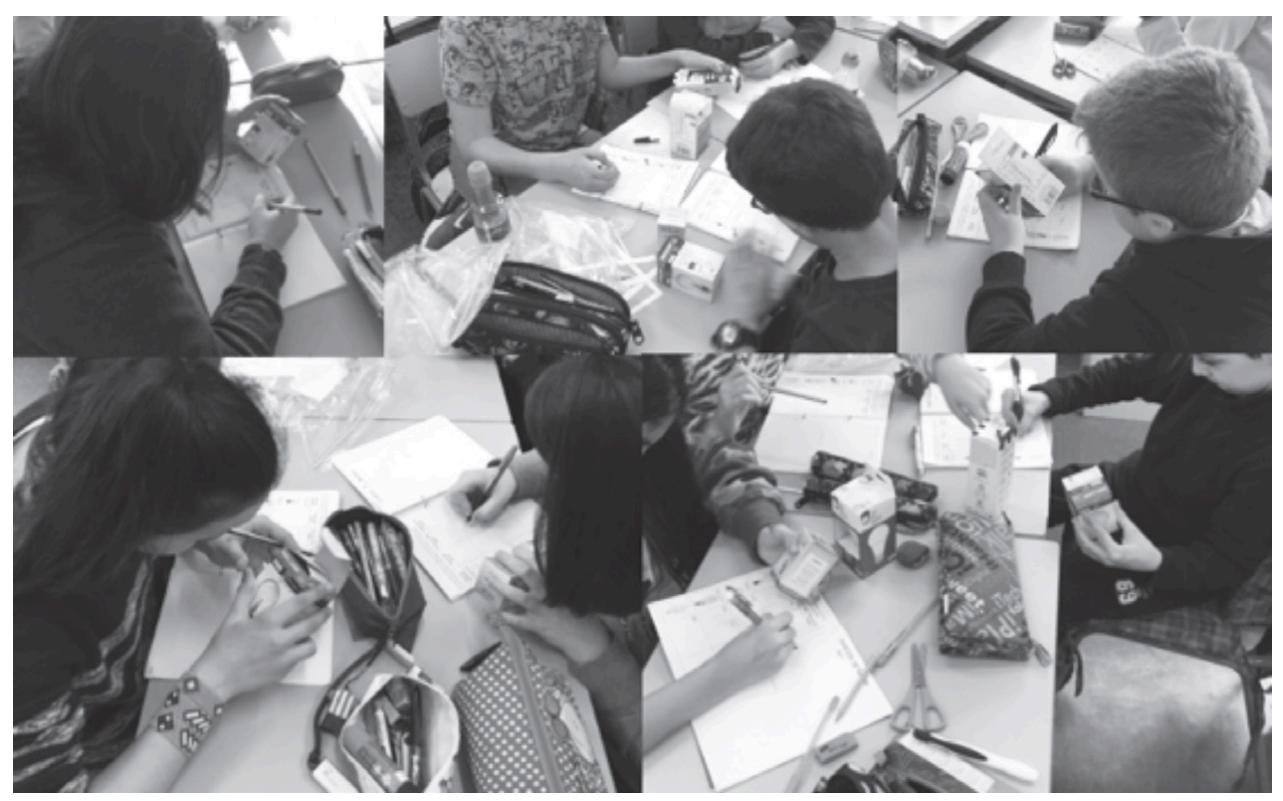

Figura 5.6. Escolares recogiendo información sobre los distintos tipos de bombillas. 


\section{SESIÓN 7:}

- Construcción de gráficos de barras:

Es momento de utilizar los datos recogidos en la tabla para realizar tres gráficos de barras, uno por cada variable registrada: consumo de electricidad, precio y horas de vida de cada tipo de bombilla (ver Figura 5.7).

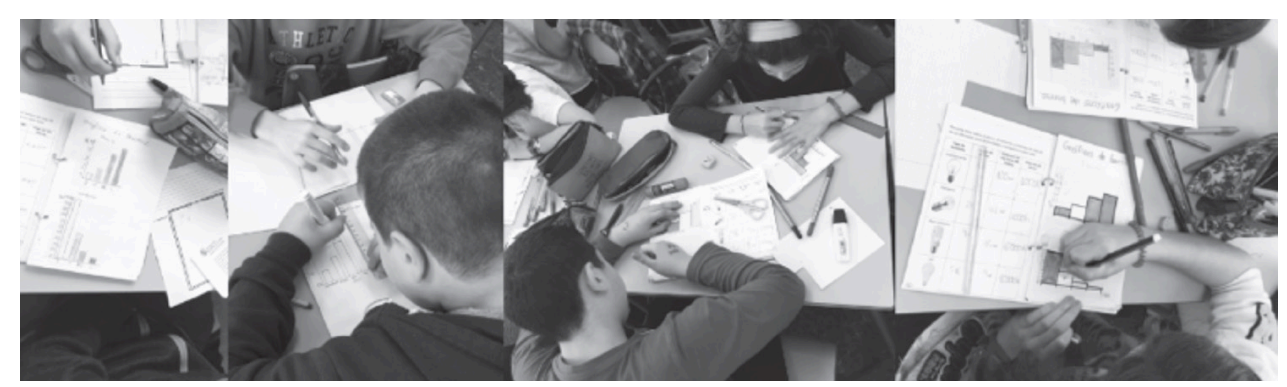

Figura 5.7. Realización de gráficos de barras.

Recuerda: Durante esta actividad es necesario dialogar y reflexionar acerca de la función de los gráficos de barras, así como hacer hincapié en algunas cuestiones que resultan de especial dificultad para el alumnado como son mantener la misma distancia en cada medida de la graduación de los ejes, o colocar el nombre de la variable representada entre paréntesis y al lado de cada eje.

\section{- Debate sobre la rentabilidad de las bombillas:}

Con toda la información extraída y posteriormente visualizada de una manera más comprensible mediante los tres gráficos, provocamos un debate sobre la rentabilidad de los distintos tipos de bombillas. El objetivo final es la definición y la elección en gran grupo del tipo de bombilla que resulta más rentable en cuanto a las variables estudiadas. Así, llegamos a la conclusión de que el tipo de bombilla más rentable es la bombilla led porque, aunque sea más cara, su consumo es mucho menor y su durabilidad bastante mayor en comparación con el resto de las bombillas. Además de construir la explicación principal también debatimos acerca de la rentabilidad entre el resto de los tipos de bombillas, por ejemplo, llegando a la conclusión de que la menos rentable es la bombilla incandescente porque, aunque su precio es menor, su consumo es el más alto y su durabilidad la más baja de todas. 


\section{SESIÓN 8:}

\section{- ¿Cuánto nos cuesta la electricidad que consumimos?}

En la introducción de esta sesión hacemos partícipes a los escolares. Cada grupo trae de su casa una factura de la luz y, a través de algunos gráficos como el de evolución del consumo - presente en todas las facturas-, se inicia una breve reflexión acerca de la relación entre el consumo y el coste que tiene la electricidad que consumimos. Además de provocar la reflexión, el objetivo de esta actividad es conocer la unidad $\mathrm{kWh}$, relacionándola con la unidad $\mathrm{W}$ que ya conocían.

\section{- Construcción de gráficos poligonales:}

Previa explicación de la función de los gráficos poligonales o de líneas, procedemos a realizar uno sobre el consumo de $\mathrm{kWh}$ por mes a través de un problema planteado. A continuación, desarrollamos una breve reflexión de su interpretación en el cuaderno de campo (Anexo 5.3). Una buena reflexión ha de aludir a las razones por las que el consumo de electricidad aumenta o disminuye y no quedarse en una mera lectura del gráfico. Así, se puede inferir que en los meses de invierno el consumo de electricidad aumenta debido a que permanecemos más tiempo en casa y hay menos horas de luz, al contrario que en la estación de verano en la que permanecemos mucho más tiempo fuera de casa y disponemos de más horas de luz. En la reflexión se puede incluso adivinar que en el mes de agosto la familia se fue de vacaciones, al comprobar que este es el mes cuyo consumo es el más bajo del año.

Recuerda: Al igual que con los gráficos de barras, en esta actividad conviene recordar la importancia de mantener siempre la misma distancia en la graduación de los ejes.

\section{SESIÓN 9:}

\section{- Recuento de bombillas:}

En base a los objetivos de trabajo de las siguientes sesiones, cada escolar ha realizado como deberes un recuento del número de bombillas de cada tipo que tiene en su casa y ha recogido los resultados en una pequeña tabla. 
- Construcción de gráficos sectoriales I:

Previa explicación de la función de los gráficos sectoriales, elaboran uno con los datos que han recopilado sobre el número de bombillas de cada tipo que cada uno tiene en su casa. Como pauta conviene especificar que añadan una leyenda de colores. Además, agregan los porcentajes que representa cada sector para obtener una información más concisa de los datos.

\section{- Agrupación de datos:}

Realizamos una puesta en común en gran grupo de los datos recopilados por el alumnado. Cada uno va insertando sus datos en una tabla de Excel proyectada en la pizarra digital. De esta manera, y tras un sencillo sumatorio, conseguimos obtener el número de bombillas de cada tipo que hay entre todo el grupo de clase.

\section{SESIÓN 10:}

- Construcción de gráficos sectoriales II:

Realizamos un segundo gráfico sectorial, en esta ocasión utilizando los datos extraídos de la tabla Excel grupal. De la misma manera, añadimos una leyenda de colores, coincidente con las variables del anterior gráfico, y anotamos los porcentajes de cada tipo de bombilla (ver Figura 5.8).

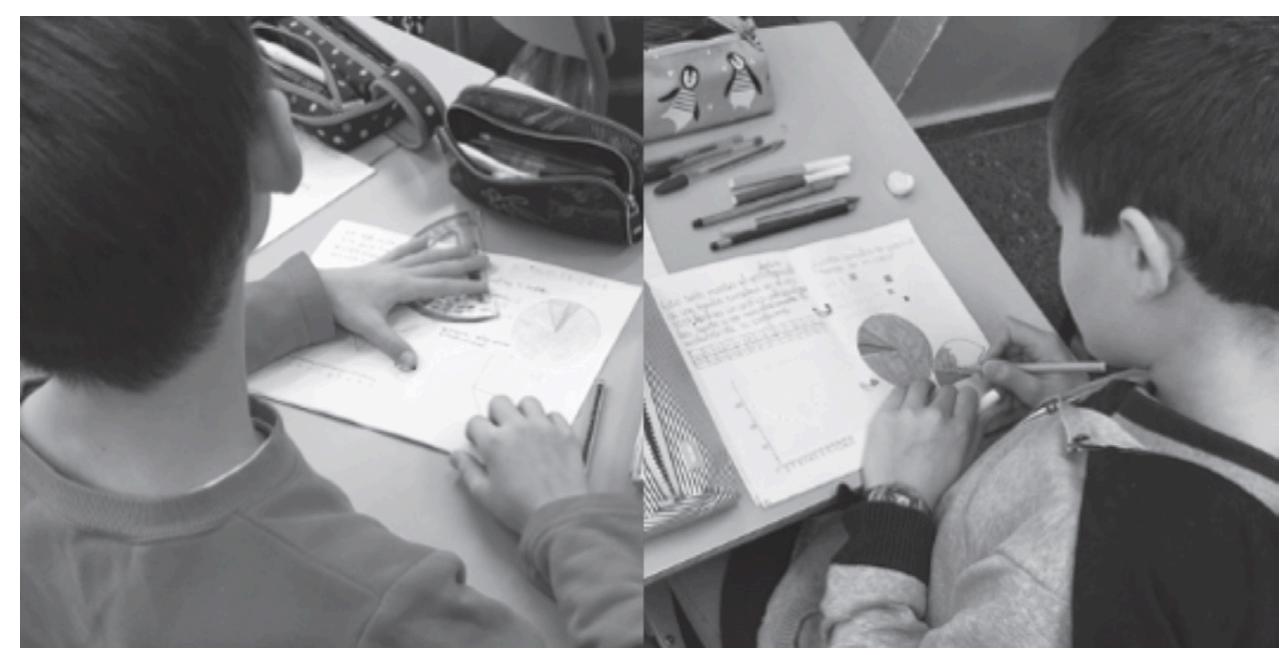

Figura 5.8. Proceso de construcción de gráficos sectoriales. 


\section{- Reflexión:}

Todo el alumnado ya ha elaborado los dos gráficos sectoriales: uno con los datos individuales y otro con los grupales. Ahora es momento de responder de manera fundamentada a las siguientes preguntas: ¿qué conviene hacer en mi casa? y ¿qué nos conviene hacer como grupo? Todo ello teniendo en cuenta las conclusiones de rentabilidad trabajadas anteriormente. El objetivo es conseguir una reflexión individual y grupal acerca del ahorro de energía y conocer que, cambiando bombillas incandescentes, halógenas y de bajo consumo por bombillas led, estaremos logrando un gran ahorro en muy poco tiempo.

\section{SESIÓN 11:}

— ¿Qué tipo de bombilla led utilizamos en nuestro prototipo? Debate breve de ideas previas sobre el color:

El alumnado ya posee gran variedad de conocimientos que empleará más adelante para diseñar su prototipo de iluminación. Conoce que ha de funcionar con corriente eléctrica, mediante un circuito y que entre sus componentes ha de incorporar bombillas led porque son las más rentables. Pero conviene ahondar aún un poco más. Existen dos tipos de bombillas led frías y cálidas-, las cuales hacen que percibamos nuestro entorno en gamas de colores diferentes. Por ello, comenzamos recopilando en la pizarra las ideas previas que el grupo posee sobre el color.

Recuerda: Como en otras ocasiones, puede resultar interesante la estimulación del debate realizando algunas preguntas, por ejemplo, «¿alguien sabe qué es exactamente el color?».

\section{— Experimentando con luzy color:}

Esta actividad representa una indagación en la que se lleva a cabo una observación de diferentes trozos de cartulina -uno blanco y otros de varios colores- que están posados en el fondo de una caja que dentro tiene instalada una bombilla multicolor. Realizamos diferentes experimentos, alumbrando con luces de diferentes colores y cambiando la bombilla multicolor por leds, primero fría y después cálida (ver Figura 5.9). En el Anexo 5.3 se puede consultar la ficha con la que el alumnado trabaja en esta actividad. 


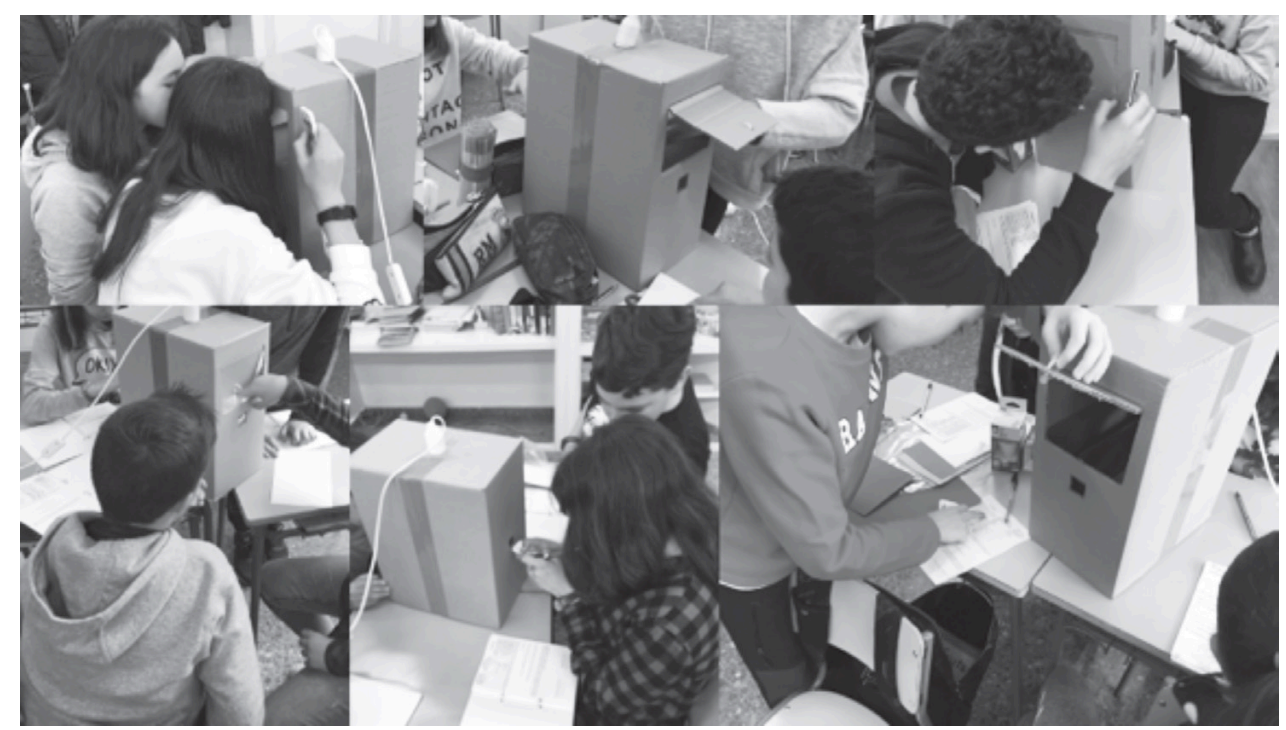

Figura 5.9. Escolares indagando acerca de la luz y el color.

- Reflexión y conclusiones:

Una vez concluida la indagación, los escolares responden en gran grupo a las preguntas relacionadas con lo experimentado (Anexo 5.3). Se trata de un momento crucial para tratar de fisurar la idea previa de que el color es una propiedad intrínseca de la materia. Para ello, se puede aludir al efecto de la luz y la oscuridad en nuestra percepción de los colores. Incluso, conviene realizar una comparación entre las respuestas para comprobar que, ante un mismo escenario, no siempre percibimos los mismos colores, añadiendo así una variable más al concepto de color -el sistema del individuo que percibe-. Una vez aclarados los conceptos fundamentales en torno al color, procedemos a la elección del tipo de bombilla led más adecuada para nuestra sala de estudio. Dada la naturalidad con la que se percibe el escenario y las sensaciones que transmite, consideramos que la luz fría es la más propicia, al menos para instalar en el foco que emita luz directa al escritorio.

\section{SESIÓN 12:}

\section{- Composición artística:}

Con el fin de experimentar más concienzudamente acerca de las sensaciones que producen los colores cálidos y fríos, creamos una composición con estas gamas. Se puede trabajar de diferentes maneras: dibujando una misma 
composición dos veces y en cada caso con una gama de colores, aplicando cada gama de colores en una parte de una misma composición, etc. (ver Figura 5.10).

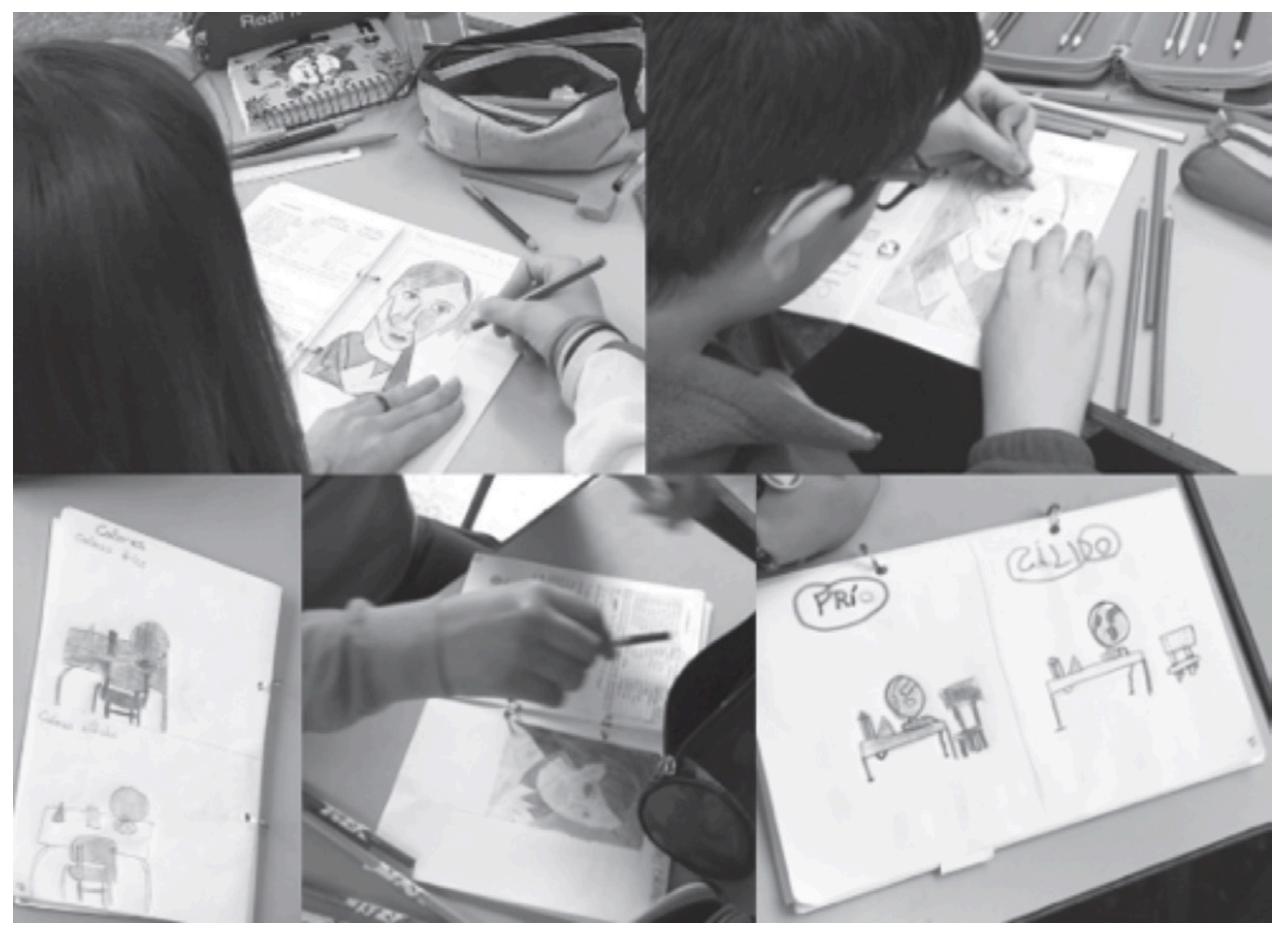

Figura 5.10. Ejemplos de composiciones artísticas realizadas por el alumnado.

Recuerda: Resulta conveniente indicar que el maestro, al tiempo en que se desarrolla la actividad, ha de mostrar en la pizarra digital las dos gamas de colores, para que el alumnado siempre las tenga presentes y pueda utilizarlas correctamente en su composición.

\section{SESIÓN 13:}

- Diseño de ingeniería:

Dedicamos unos minutos a recordar el problema principal y a realizar una recapitulación de los conocimientos clave que han sido trabajados para el diseño del prototipo de iluminación. En este momento, el alumnado ha de conocer que su prototipo funcionará con corriente eléctrica, mediante un circuito; que entre sus componentes ha de incorporar bombillas led porque son 
las más rentables; y que, al menos, la bombilla que enfoque al escritorio tendrá que ser fría.

\section{- Requisitos y especificaciones para el prototipo:}

Es ahora cuando planteamos finalmente el problema de ingeniería en el que han de aplicar todos sus conocimientos. El problema planteado es el siguiente: Diseña con tu equipo un prototipo de iluminación que se ajuste a las características de iluminación de la babitación que os ha tocado. Como minimo debéis incorporar una cama, una mesa de estudio y una silla. Como todo proceso ingenieril, después de plantear el problema, se debe indicar una serie de limitaciones o requisitos a cumplir en el diseño. En nuestro caso, planteamos el siguiente requisito: el prototipo tiene que resultar lo más rentable posible según todo lo que has estudiado.

\section{- Diseño del prototipo:}

Se reparte a cada grupo un plano distinto de una habitación vista de planta (Anexo 5.3). Es en este plano donde han de diseñar su prototipo de iluminación de acuerdo a su requisito. Cada grupo realiza en consenso un boceto de su prototipo de iluminación para después plasmarlo individualmente en el plano de su habitación, el cual posee una escala para guiar la proporción de los diseños. Además, han de tener en cuenta la simbología usada para representar las bombillas, así como la utilización del color azul o amarillo para indicar el tipo -fría o cálida-. Para finalizar, realizan una explicación detallada de su diseño aclarando aspectos como el número de bombillas que han colocado, la estrategia que han seguido para su ubicación, el tipo y color de bombillas que han elegido e incluso cuestiones relacionadas con el aprovechamiento de la luz natural.

\section{SESIONES 14 y 15:}

\section{- Preparación de las presentaciones:}

Es el momento de comunicar todo lo aprendido. Dedicamos dos sesiones a la preparación de una presentación grupal en la que cada miembro se encarga de una parte de los contenidos abordados — la electricidad, los circuitos, los tipos de bombillas y el color- para finalmente exponer entre todos el diseño de su prototipo de iluminación.

Recuerda: Durante el desarrollo de esta actividad, conviene aclarar a los escolares que las presentaciones no se deben leer textualmente, sino que es 
necesario relatar su contenido teniendo una idea más amplia de lo que se da a conocer.

\section{SESIÓN 16:}

\section{- Comunicación de datos:}

Esta sesión está íntegramente dedicada a la presentación de todos los grupos. Ya para terminar, y no menos importante en el diseño de ingeniería, no debemos olvidar las propuestas de mejora para los diseños. Aportamos diversas opiniones sobre lo que consideramos que convendría cambiar en los diseños.

Recuerda: Las propuestas de cambio se realizan en gran grupo después de cada presentación y siempre desde un punto de vista constructivo.

\section{- Aplicación de mejoras y recogida del cuaderno de campo:}

Estimamos el plazo oportuno para que todos los grupos concluyan su proyecto dibujando el prototipo final en el que han de incluir las mejoras para finalmente entregar su cuaderno de campo completo, el cual será objeto de evaluación (ver Figura 5.11).

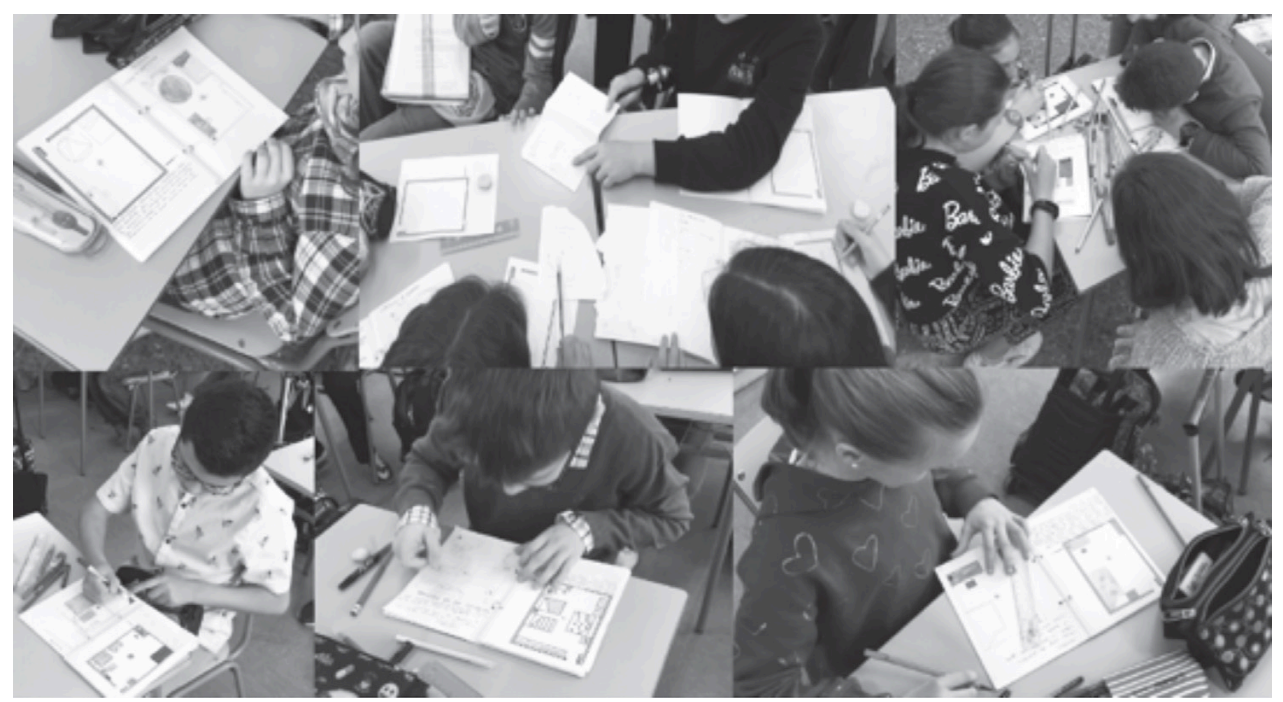

Figura 5.11. Algunos momentos del proceso de diseño y mejora del prototipo. 


\subsection{Posibles adaptaciones}

El campo de la electricidad resulta particularmente moldeable para su enseñanza en diversos contextos y situaciones educativas. En este caso, proponemos una posible adaptación que puede servir tanto para llevar a cabo la presente unidad, o parte de ella, en cursos de enseñanza primaria más tempranos, como para propiciar una mayor inclusión del alumnado con discapacidad motora o con problemas de motricidad fina.

Como se ha podido comprobar, el montaje de diferentes tipos de circuitos y la realización de distintos experimentos en torno al concepto de corriente eléctrica representan la parte elemental de esta propuesta. Una buena forma de llevar a cabo diferentes experimentos eléctricos con alumnado de menor edad es la utilización de plastilina como elemento conductor entre los diferentes componentes del circuito. En vez de utilizar los clásicos tramos de cable que a veces conllevan impedimentos en su manipulación, podemos utilizar una plastilina conductora que puede ser manufacturada o adquirida en el mercado. Esta sustitución de material hace que tanto el alumnado de temprana edad como con discapacidad motora o problemas de motricidad fina pueda conseguir de una manera mucho más sencilla y asequible realizar circuitos y demás experimentos eléctricos de esta índole. Los pedazos de plastilina conductora de diferentes formas sirven para después pinchar pequeñas bombillas led que lucirán en serie o en paralelo según la estructura construida. También podemos utilizarla para unirla a los cables de cualquier otro tipo de receptor, por ejemplo, un pequeño motor, un timbre o un ventilador. Otra modalidad es la incorporación de otro tipo de plastilina aislante- que da acceso, además, al estudio de los materiales conductores y aislantes desde una perspectiva diferente. Es destacable que, además de las oportunidades de adaptación que nos brinda el uso de la plastilina, esta abre todo un mundo de posibilidades artísticas y creativas que podrían tener cabida en propuestas de educación STEAM.

Para adaptar el resto de esta unidad, bastará con adoptar los contenidos acordes al currículo del curso en el que se vaya a implementar y adecuar el problema principal a una situación real del contexto para no perder la esencia motivadora. 



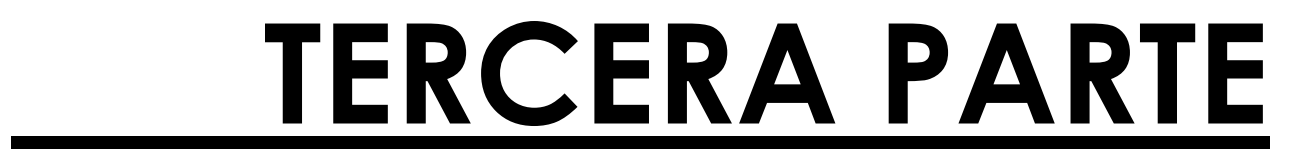

Metodología, análisis y resultados 



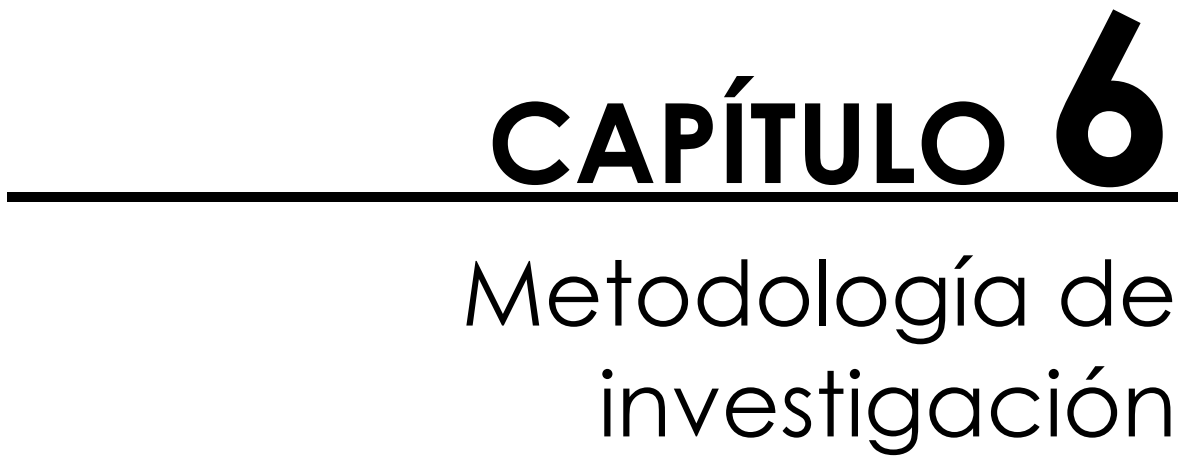



$\mathrm{E}$

n este capítulo se presenta, de manera detallada, la metodología de investigación empleada para evaluar la implementación de la UD STEAM en términos de competencias y actitudes. En primer lugar, se despliega el diseño metodológico general construido para dicha evaluación. Después, se relata el proceso de recolección de datos y se continúan definiendo las características de la muestra, así como su estrategia de selección. Finalmente, se especifican las características del análisis de datos llevado a cabo.

Indicar que este capítulo contiene información procedente de algunos trabajos previos (Ortiz-Revilla y Greca, 2019; Ortiz-Revilla, Greca y Meneses Villagrá, 2019).

\subsection{Diseño}

Dado que el diseño metodológico construido se basa tanto en la investigación de métodos mixtos como en la investigación de diseño, se presenta dividido en estas dos subsecciones.

\subsubsection{Investigación de métodos mixtos}

En congruencia con la complejidad que entraña la evaluación competencial, en este estudio se combinaron y complementaron los enfoques cualitativo y cuantitativo, estableciéndose una investigación de métodos mixtos, la cual proporciona en ocasiones una mejor comprensión del problema y de las preguntas de la investigación que cualquiera de los dos métodos por sí mismos. (Creswell y Creswell, 2018; Creswell y Plano Clark, 2018). Al operar desde ambos paradigmas de manera simultánea —es decir, ambos tipos de datos, cualitativos y cuantitativos, siempre se recopilaron antes de completar el análisis de alguno de ellos - y presentar una prioridad cualitativa — esto es, otorgar un mayor estatus a los componentes cualitativos, por considerarse más relevantes para abordar el propósito del estudio-, la investigación se enmarcó dentro de la tipología de un diseño de métodos mixtos paralelo convergente QUAL + quan (Creswell y Guetterman, 2019). En la Figura 6.1 se ilustra el diagrama de este diseño. 


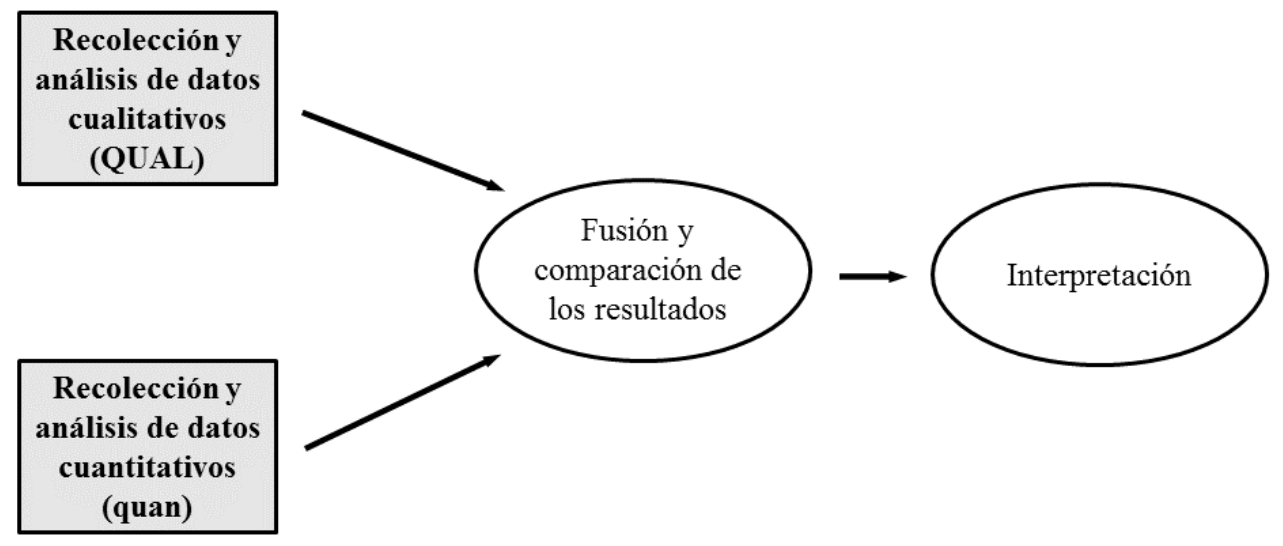

Figura 6.1. Diagrama del diseño de métodos mixtos paralelo convergente QUAL + quan empleado en la investigación. Adaptada de Creswell y Plano Clark (2018).

\subsubsection{Investigación de diseño}

La discusión acerca de la falta de relevancia para la práctica de gran parte de la investigación educativa producida se trata de un tema candente, sobre todo, en las últimas décadas. Así, son numerosas las investigaciones que han reivindicado la necesidad de enfoques investigativos que se sumerjan fehacientemente en los grandes problemas de la práctica educativa (NRC, 2002; The Design-Based Research Collective [DBRC], 2003). Debido a esta situación y con objeto de establecer un mayor compromiso ontológico en cuanto a las cuestiones esenciales relacionadas con el aprendizaje, surge un paradigma metodológico que aúna la reflexión conjunta de investigadores y profesionales de la práctica educativa.

En esta investigación se trabajó concretamente desde este paradigma metodológico denominado Design-Based Research (Barab y Squire, 2004; DBRC, 2003), investigación de diseño o investigación basada en diseño en su traducción al idioma español, el cual admite ambos enfoques, cualitativo y cuantitativo y emplea métodos mixtos para analizar los resultados de una intervención y refinarla (Anderson y Shattuck, 2012; DBRC, 2003). Dada la relevancia para el campo educativo de este paradigma metodológico nos permitiremos extender una breve explicación. 
La investigación de diseño surge de los estudios de Brown (1992) y Collins (1992) dada la necesidad de comprender la naturaleza y las condiciones del aprendizaje en ámbitos naturalistas de una manera contextualizada y holística. No constituye tanto un enfoque como un conjunto de herramientas metodológicas que pueden ser engranadas con la intención de producir nuevas teorías, modelos, prácticas, herramientas tecnológicas, planes de estudio, etc. que ayuden a comprender y predecir sistemáticamente cómo se produce el aprendizaje y que generen un mejor potencial de influencia en el proceso de enseñanza-aprendizaje (Barab y Squire, 2004).

Si bien existen puntos comunes entre este paradigma metodológico y la metodología de investigación-acción como, por ejemplo, la retroalimentación teórico-práctica y el afán por comprender o mejorar la realidad educativa, su propia taxonomía ya establece algunas diferencias. Plomp (2013) definió la investigación de diseño como «el estudio sistemático del diseño, el desarrollo y la evaluación de intervenciones educativas» (p. 11), por ejemplo, de programas, ambientes de aprendizaje o estrategias de enseñanzaaprendizaje. Su objetivo es proporcionar soluciones a los problemas complejos de la práctica educativa a la par de avanzar en el conocimiento sobre las características de estas intervenciones, su diseño y su desarrollo. Nótese que, a diferencia de la metodología de investigación-acción, en este paradigma pueden emplearse diversas herramientas metodológicas, tanto cualitativas como cuantitativas, entre ellas la propia investigación-acción.

El proceso de investigación sobre este paradigma metodológico ha sido detallado por algunos autores y para diferentes campos educativos (BannanRitland, 2003; Reeves, 2006). En particular, se pueden extraer algunas fases comunes de los estudios de desarrollo basados en este paradigma metodológico (Plomp, 2013): la investigación preliminar —en la que se detectan las necesidades del contexto, se revisa la literatura y se construye el marco teórico-, la creación de prototipos —en este caso, de las planificaciones de la $\mathrm{UD}$, en la que se diseñan y se ponen a prueba las sucesivas iteraciones con el objetivo de mejorar y refinar la intervención - y la evaluación —en la que se concluye si la intervención cumple con las especificaciones predeterminadas-

Por último, destacar que el potencial teórico-práctico de la investigación de diseño para la investigación educativa y, en especial, para la Didáctica de las Ciencias ya ha sido argumentado por algunos autores (Kelly, 
Lesh y Baek, 2008). Estudios a nivel nacional como el de Molina, Castro, Molina y Castro (2011) en el ámbito de la Didáctica de las Matemáticas han aportado aún más evidencias de su valía. Así, en línea con Molina et al. (2011) creemos necesario contribuir a su divulgación y progreso, en este caso, ampliando su horizonte a la aplicación en investigación educativa transdisciplinaria.

\subsection{Recolección de datos}

En congruencia con el marco teórico de la investigación de diseño, se diseñó e implementó una UD STEAM (Ortiz-Revilla, 2018) con el objetivo de proporcionar solución a un problema complejo de la práctica educativa. Como se ha comentado, el problema planteado emanó de la necesidad detectada previa revisión de la literatura, construcción del encuadre teórico y estudio de las necesidades contextuales (Capítulos 2, 3 y 4)— de planificar e implementar propuestas didácticas transdisciplinarias, viables en contextos naturales de Educación Primaria y comprometidas con la potenciación del desarrollo competencial del alumnado.

La ampliación de la muestra de alumnado fue progresiva desde la implementación del primer prototipo de la UD — producto del investigadorhacia los sucesivos prototipos — productos de la reflexión conjunta, basada en las evidencias disponibles, del investigador y los profesionales de la práctica educativa- El primer prototipo se ejecutó en un solo grupo de estudiantes, el segundo prototipo en dos grupos y el tercero en tres. Indicar que, dentro de la fase de creación de prototipos, fue el maestro de la primera iteración el que contó con más acompañamiento en la práctica, debido a que al aumentar el número de grupos en las sucesivas iteraciones el investigador tuvo, lógicamente, que dividir su tiempo de estancia en cada aula.

Como técnicas de recolección de datos, desde la parte cualitativa se empleó la observación participante a través del registro de notas de campo (Spradley, 2016) por parte del investigador y los maestros inmersos en el contexto de enseñanza-aprendizaje y el material elaborado por el alumnado (Massot Lafon, Dorio Alcaraz y Sabariego Puig, 2004), en este caso su cuaderno de campo personal. Desde la parte cuantitativa se empleó el conjunto de datos numéricos deducidos del análisis cualitativo, según se explica más adelante, y 
una adaptación al español realizada en el marco de esta investigación del instrumento de evaluación de las actitudes del alumnado hacia la ciencia BRAINS (Summers y Abd-El-Khalick, 2018).

\subsubsection{Descripción detallada de los instrumentos de recolección de datos}

A continuación, se realiza una descripción detallada de los instrumentos empleados en el proceso de recolección de datos.

- Cuaderno de campo personal. Aunque se dividió al alumnado de cada grupo en pequeños subgrupos de trabajo — de tres o cuatro alumnos, que tenían un color de cuaderno diferente, este material se realizó individualmente por cada alumno, si bien pudieron en algunos momentos de trabajo grupal consensuar algunas opiniones. Su interior se compuso de las 17 actividades en que se dividió el completo desarrollo de la UD y que mantenían relación con los EAE correspondientes a los contenidos tratados. Su plausibilidad de utilización en el aula fue avalada por todos los maestros y los propios participantes del proceso de enseñanza-aprendizaje. Como se comentó, en el Anexo 5.3 se muestran tres ejemplos de cuaderno de campo ya completados tras finalizar la UD.

- Adaptación al español del instrumento de evaluación de las actitudes del alumnado hacia la ciencia BRAINS. Para su adaptación transcultural el instrumento fue traducido de su versión original en inglés al español utilizando la traducción directa e inversa (Borsa, Damàsio y Bandeira, 2012). Además de una serie de entrevistas al alumnado acerca de la comprensión del instrumento, se tuvo en consideración una versión piloto para comprobar si existían diferencias entre el uso del término «ciencias» — science en su versión original— y Ciencias de la Naturaleza —utilizado en español como sinónimo de science-, no obteniéndose ninguna diferencia. Además, dado que no existen instrumentos en la literatura que evalúen conjuntamente las actitudes hacia la ciencia y la ingeniería y en esta tesis se engloban ambos aspectos, se agregaron algunos ítems estructurados de manera semejante y relacionados con la intención hacia la ingeniería. El instrumento completo traducido con la 
incorporación de estos nuevos ítems se encuentra en proceso de validación con un grupo más grande y, aunque el instrumento original cuenta con cinco constructos, aquí se presentan los resultados teniendo en consideración dos de ellos: Actitudes hacia la ciencia -ítems 28, 18, $35,1,7$ y 27 - e Intención hacia la ciencia -ítems 23, 19, 32, 4, 15 y 12-; y los dos añadidos, Intención hacia la ingeniería —ítems 10, 13, 16 y 24 - e Intención hacia STEM — constructo de Intención hacia la ciencia + constructo de Intención hacia la ingeniería-. En el Anexo 6.1 se muestra la versión final utilizada. Cabe destacar que los constructos de «Intención» estudian la intención de continuar ciencias o ingeniería, ya sea a través de futuras asignaturas o de carreras universitarias. En esta tesis, siguiendo el instrumento original, se emplea para ello la denominación de Intención hacia la ciencia, Intención hacia la ingeniería e Intención hacia STEM.

\subsection{Contexto}

La propuesta se llevó a cabo durante el curso académico 2017-2018 en el Colegio de Educación Infantil y Primaria (CEIP) público Fernando de Rojas, situado en el barrio de Gamonal-Capiscol — G-9 — de la ciudad de Burgos Castilla y León, España—. El centro se empezó a construir en el año 1979 en lo que fue la zona de expansión de Burgos, en las proximidades de un polígono industrial. La población del G-9 y su entorno creció muy deprisa, con lo que la demanda de puestos escolares fue máxima. Así, tras varias ampliaciones, hoy es un colegio de seis líneas con capacidad para 1350 alumnos y con cinco edificios — dos destinados a la Educación Infantil, dos a Educación Primaria y un polideportivo - rodeados por una valla de 800 metros que delimita una amplia zona escolar con espacios ajardinados y arbolados, pistas deportivas y de recreo. Como particularidades, comentar que la Administración Educativa determinó que fuese de preferente escolarización de alumnado con discapacidad motora. Además, el centro cuenta con la jornada continua — de 09:00 horas a 14:00 horas-, aunque aquellas familias que, por razones de trabajo y atendiendo a la conciliación de la vida familiar y laboral, lo necesiten, pueden solicitar los programas de madrugadores — de 07:45 horas a 09:00 horas-. También cuenta con un servicio de comedor escolar, que prolonga la 
estancia en el centro desde las 14:00 horas hasta las 16:00 horas. De 16:00 horas a 18:00 horas se ofrecen actividades extraescolares de participación opcional.

Actualmente el barrio cuenta con una amplia variedad de infraestructuras: el gran polígono industrial junto al que se construyó el centro, además de varios lugares de ocio — plazas y parques-, centros culturales bibliotecas, centros cívicos etc.- zonas deportivas - polideportivos, piscinas, pistas deportivas, etc.- , centros sanitarios públicos y privados, centros educativos públicos y privados y gran variedad de centros comerciales supermercados, tiendas, mercado de abastos, etc.-.

El alumnado -1200 en el curso académico 2017-2018 - proviene principalmente de las escuelas infantiles que se encuentran en las inmediaciones, aunque también hay que destacar quienes, por razones de trabajo de los padres, eligen este centro. Las familias del alumnado pertenecen en su mayor medida a la clase obrera y existe un cierto porcentaje de alumnado migrante en su mayoría procedente de Rumanía, pero de hasta 25 nacionalidades diferentes. El profesorado es en su mayoría funcionario de carrera, sin existir apenas interinaje, por lo que el centro cuenta con una plantilla docente bastante estable.

En este contexto se realizaron un total de tres reuniones previas a la inmersión del investigador en el centro. En primer lugar, se convocó una reunión con el equipo directivo del centro, donde el investigador expuso la propuesta de intervención. Tras el visto bueno de la dirección del centro y, dado que la intervención implicaba un cambio bastante considerable en las rutinas habituales, en segundo lugar, se requirió una segunda reunión, en este caso con la Comisión de Coordinación Pedagógica (CCP), en la que se discutió de manera más detallada la viabilidad de la propuesta. Tras una serie de acuerdos entre el investigador y estos órganos y la evaluación positiva de los maestros de sexto de primaria acerca de la posibilidad de llevar a cabo la propuesta, se procedió a concertar la tercera y última reunión, en este caso, ya con los futuros maestros participantes, donde el investigador explicó con máximo detalle las características de la propuesta y el papel que adquirirían durante la investigación. De nuevo, tras una serie de acuerdos y negociaciones —duración, temporalización, contenidos a abordar-, los seis maestros implicados decidieron llevar a cabo la propuesta. Indicar que, por último, se otorgó total libertad a los maestros en cuanto a la distribución temporal de su participación, siendo ellos los que decidieron que el maestro más entusiasmado 
por la enseñanza de las ciencias comenzara desarrollando el primer prototipo con su grupo de alumnos.

Destacar que la propuesta de intervención fue informada positivamente por el Director Provincial de Educación de Burgos —Delegación Territorial de Burgos, Dirección Provincial de Educación, Junta de Castilla y León-, dado que implicaba cambios en la temporalización y organización de las evaluaciones previstas por el centro y acordadas con el Inspector del mismo. Para preservar la conducta ética de una investigación en la que participan humanos, se cumplieron los estándares éticos 8.01-8.09 establecidos por American Psychological Association (2017).

\subsection{Participantes}

En el estudio participaron un total de $121(\mathrm{~N}=121)$ escolares (54.54\% chicos), divididos en seis grupos $(n=20, n=21, n=20, n=20, n=19$ y $n=21$, respectivamente) con sus respectivos maestros y cuyas edades se comprendían entre los 11 y los 13 años $(M=11.33, D E=.52)$. Todos ellos cursaban el sexto curso de Educación Primaria y no hubo casos perdidos. Para completar la descripción de la muestra, en las Tablas 6.1 y 6.2. se muestra un recuento de esta cruzando las variables de edad, género y prototipo; y edad, género y grupo, respectivamente.

Tabla 6.1. Recuento de la muestra según edad, género y prototipo

\begin{tabular}{llrrrr}
\hline \hline \multirow{2}{*}{ Prototipo } & & \multicolumn{3}{c}{ Género } & \\
\cline { 3 - 5 } & & & Chico & Chica & Total \\
\hline Prototipo 1 & Edad & 11 & 11 & 9 & 20 \\
\cline { 2 - 5 } & Total & & 11 & 9 & 20 \\
\hline Prototipo 2 & Edad & 11 & 17 & 12 & 29 \\
& & 12 & 4 & 7 & 11 \\
& & 13 & 1 & 0 & 1 \\
\cline { 2 - 5 } & Total & & 22 & 19 & 41 \\
\hline Prototipo 3 & Edad & 11 & 16 & 19 & 35 \\
& & 12 & 16 & 7 & 23 \\
& & 13 & 1 & 1 & 2 \\
\hline
\end{tabular}




\begin{tabular}{lrrrrr} 
& Total & & 33 & 27 & 60 \\
\hline Total & Edad & 11 & 44 & 40 & 84 \\
& 12 & 20 & 14 & 34 \\
& & 13 & 2 & 1 & 3 \\
\cline { 3 - 6 } & & & 66 & 55 & 121 \\
\hline \hline
\end{tabular}

Tabla 6.2. Recuento de la muestra según edad, género y grupo

\begin{tabular}{|c|c|c|c|c|c|}
\hline \multirow[b]{2}{*}{ Grupo } & & & \multicolumn{2}{|c|}{ Género } & \multirow[b]{2}{*}{ Total } \\
\hline & & & Chico & Chica & \\
\hline \multirow[t]{2}{*}{ Grupo 1} & Edad & 11 & 11 & 9 & 20 \\
\hline & Total & & 11 & 9 & 20 \\
\hline \multirow[t]{3}{*}{ Grupo 2} & Edad & 11 & 9 & 6 & 15 \\
\hline & & 12 & 1 & 5 & 6 \\
\hline & Total & & 10 & 11 & 21 \\
\hline \multirow[t]{4}{*}{ Grupo 3} & Edad & 11 & 8 & 6 & 14 \\
\hline & & 12 & 3 & 2 & 5 \\
\hline & & 13 & 1 & 0 & 1 \\
\hline & Total & & 12 & 8 & 20 \\
\hline \multirow[t]{3}{*}{ Grupo 4} & Edad & 11 & 5 & 7 & 12 \\
\hline & & 12 & 5 & 3 & 8 \\
\hline & Total & & 10 & 10 & 20 \\
\hline \multirow[t]{4}{*}{ Grupo 5} & Edad & 11 & 7 & 7 & 14 \\
\hline & & 12 & 4 & 0 & 4 \\
\hline & & 13 & 1 & 0 & 1 \\
\hline & Total & & 12 & 7 & 19 \\
\hline \multirow[t]{4}{*}{ Grupo 6} & Edad & 11 & 4 & 5 & 9 \\
\hline & & 12 & 7 & 4 & 11 \\
\hline & & 13 & 0 & 1 & 1 \\
\hline & Total & & 11 & 10 & 21 \\
\hline \multirow[t]{4}{*}{ Total } & Edad & 11 & 44 & 40 & 84 \\
\hline & & 12 & 20 & 14 & 34 \\
\hline & & 13 & 2 & 1 & 3 \\
\hline & Total & & 66 & 55 & 121 \\
\hline
\end{tabular}


La estrategia de selección de la muestra se correspondió categóricamente con un muestreo no probabilístico por conveniencia. No obstante, se tomó en consideración la necesidad de contar con un centro de seis líneas para el desarrollo de las tres iteraciones programadas con su progresivo aumento de la muestra. En la Figura 6.2 se muestra el esquema del modo en que se pusieron a prueba, en las sucesivas iteraciones, los tres prototipos.

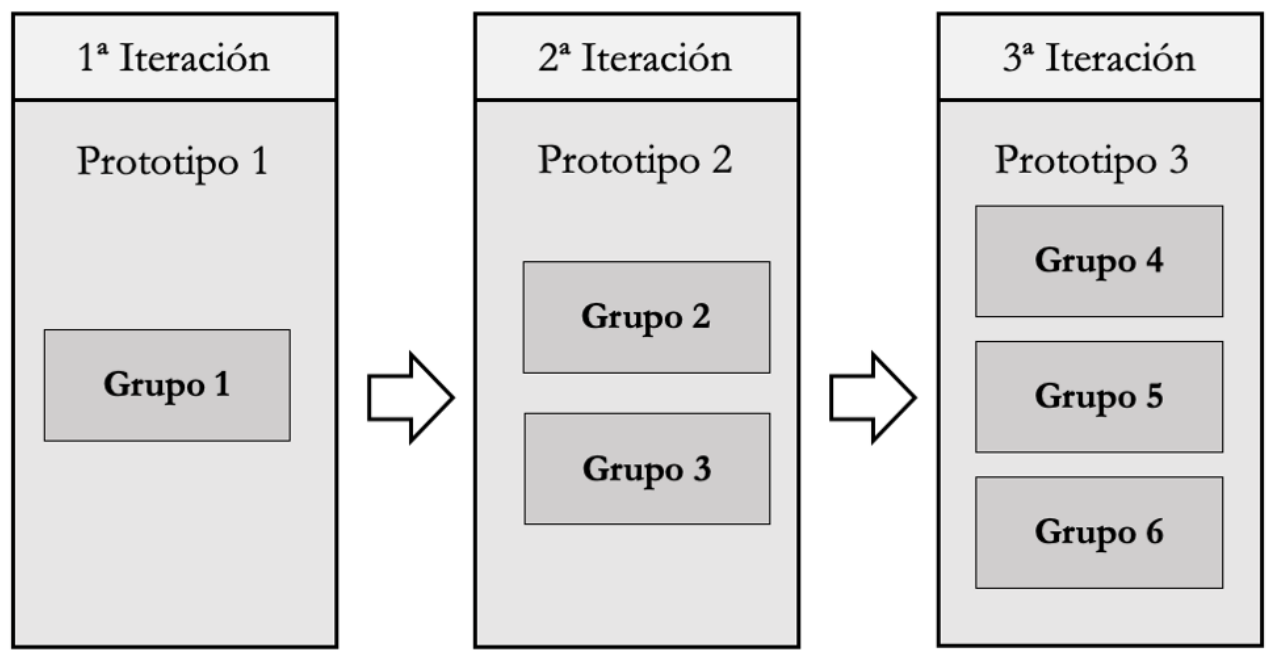

Figura 6.2. Esquema de la secuenciación de las tres iteraciones y los tres prototipos. Adaptada de Ortiz-Revilla, Greca y Meneses Villagrá (2019).

Para evaluar el efecto resultante de la aplicación de la UD en las actitudes hacia la ciencia y la intención de seguir carreras científico-tecnológicas se contó con una muestra de 137 alumnos de quinto curso del mismo centro. Se empleó así un diseño cuasi-experimental de cohortes, justificado dado que el alumnado de $5^{\circ}$ curso poseía características socio-culturales y demográficas semejantes al de sexto. Además, el instrumento se aplicó al finalizar el curso escolar, por lo que sus edades fueron también similares a las del alumnado de sexto antes de comenzar a aplicarse la UD. Se decidió optar por este diseño para tratar de interferir lo menos posible en el desarrollo habitual de las clases ordinales de sexto curso antes de la implementación. 


\subsection{Análisis de datos}

En congruencia con el diseño de métodos mixtos, en esta sección se especifican las características relativas al análisis cualitativo, cuantitativo y mixto de los datos.

\subsubsection{Análisis cualitativo}

A continuación, se presentan tres partes diferenciadas del análisis cualitativo llevado a cabo.

\subsubsection{Interpretación de las notas de campo}

Las notas de campo obtenidas a través de la observación participante fueron objeto de una interpretación conjunta llevada a cabo entre el investigador y los maestros inmersos en el contexto de enseñanza-aprendizaje, reduciéndose y organizándose la información a través de la generación de categorías por razonamiento inductivo que dieron lugar a las mejoras de los sucesivos prototipos de la UD. Esta labor se realizó en el lapso de dos semanas, programado entre cada una de las tres iteraciones. En este sentido se prestó máxima atención a las necesidades contextuales. Por tanto, siguiendo el paradigma metodológico de la investigación de diseño se trató aquí de paliar la brecha entre investigación y práctica compenetrando las opiniones, las sugerencias de mejora y los conocimientos del investigador y los seis maestros participantes.

\subsubsection{Rúbrica de evaluación de las actividades de la UD y escala de observación de EAE}

Para poder determinar la influencia de la implementación de una UD STEAM en el plano competencial general del alumnado de Educación Primaria, por una parte, se efectuó un análisis documental (del Rincón Igea, Arnal Agustín, Latorre Beltrán y Sans Martín, 1995) de los cuadernos de campo personales del alumnado. Este análisis consistió en una calificación por parte de cada 
respectivo maestro de las 17 actividades de la UD. Para este análisis se dotó a cada maestro de una rúbrica (Anexo 6.2) donde figuraba una tabla con el listado de todas las actividades y casillas donde marcar tres posibilidades de calificación de cada una de ellas: Bien (B), Regular (R) y Mal (M). En el Anexo 6.3 se muestra un ejemplo de la actividad 9 evaluada por un mismo maestro a tres alumnos con las tres calificaciones diferentes. No obstante, para mantener el espíritu cualitativo de la información, no se otorgaron criterios restrictivos de consideración de estas tres posibilidades, respetando la subjetividad del criterio de cada maestro en su propia valoración interpretativa. Aclarar que la calificación de las actividades 15 y 17 difirió ligeramente de este procedimiento. Para la calificación de la actividad 15 no se acudió al cuaderno de campo de cada alumno sino al documento de presentación preparado por cada grupo de alumnos y se prestó especial atención a la presentación oral. La actividad 17, por su parte, fue calificada como un conjunto de actividades inmersas en ella.

Simultáneamente, a través de una escala de observación (Sabariego Puig, 2004) con las mismas posibilidades de calificación anteriores - B, R y $\mathrm{M}$-, los maestros también evaluaron lo que aquí se ha denominado EAE Globales (EAEG), al considerarse que este tipo de estándares no pueden ser evaluados mediante actividades plasmadas en un documento tangible como en el caso anterior. Por tanto, a través de la observación de su alumnado, cada maestro calificó tres EAEG, de nuevo respetándose su valoración interpretativa. Esta escala de observación también se proporcionó a los maestros añadida al mismo documento de la rúbrica anterior (Anexo 6.2).

\subsubsection{Instrumento de evaluación del desarrollo competencial escolar}

A continuación, todas las calificaciones de los maestros fueron integradas para determinar el nivel competencial escolar alcanzado por el alumnado. Para ello, fue creado un instrumento ad hoc para esta investigación que, respetando las indicaciones de la legislación (Orden ECD 65/2015, 2015; RD 116/2014, 2014), partió de la evaluación nombrada de las actividades desarrolladas por el alumnado para obtener el grado de consecución de sus respectivos EAE oficiales y posteriormente calcular el porcentaje y el grado de adquisición competencial, tanto de su Competencia general (CG) como de cada una de las competencias clave: Competencia en comunicación lingüística (CCL), Competencia matemática y competencias básicas en ciencia y tecnología 
(CMCT), Competencia digital (CD), Competencia para aprender a aprender (CPAA), Sentido de la iniciativa y espíritu emprendedor (SIE), Conciencia y expresiones culturales (CEC) y Competencias sociales y cívicas (CSC). Indicar que, teniendo en cuenta lo expuesto en el Capítulo 2 sobre lo que entendemos por competencia, el desarrollo competencial a evaluar en el marco de la educación obligatoria se correspondió con lo que denominamos competencia escolar, ya que el término competencia engloba un espectro más amplio que transciende al aula ordinaria. Destacar también que consideramos válido a este instrumento para que maestros y profesorado puedan emplearlo dentro de cualquier metodología, tanto en la Educación Primaria como en la ESO, y que, por tanto, constituye un conocimiento básico en la actual formación de estos docentes. Estos datos se trataron mediante estadística descriptiva. En el Anexo 6.4 se aporta información sobre la estructura del instrumento, las instrucciones que se siguieron para el desarrollo del análisis y un ejemplo concreto de evaluación.

Además, se quiso comprobar y validar la fiabilidad del instrumento creado por el investigador sometiéndolo a un juicio por un panel de expertos (Anexo 6.5) de cada competencia clave, cuya tarea consistió en relacionar los diversos EAE de la UD con la competencia que se consideró de su dominio — tarea anteriormente realizada por el investigador y los maestros-. Así, a través de una serie de reuniones individualizadas — de 90 minutos aproximadamente - con cada uno de los expertos se conformó una segunda variante del instrumento (Anexo 6.6). Los datos obtenidos de la valoración interjueces, así como la tasa de acuerdo con el investigador y los maestros se muestran en la Tabla 6.3. 
Tabla 6.3. Datos de la valoración interjueces y tasa de acuerdo con el investigador y los maestros

\begin{tabular}{|c|c|c|c|c|c|c|c|}
\hline EAE & $\begin{array}{c}\text { CCL } \\
\text { IyM/E }\end{array}$ & $\begin{array}{l}\text { CMCT } \\
\mathrm{IyM} / \mathrm{E}\end{array}$ & $\begin{array}{c}\mathrm{CD} \\
\mathrm{IyM} / \mathrm{E}\end{array}$ & $\begin{array}{l}\text { CPAA } \\
\mathrm{IyM} / \mathrm{E}\end{array}$ & $\begin{array}{c}\text { SIE } \\
\text { IyM/E }\end{array}$ & $\begin{array}{c}\mathrm{CEC} \\
\mathrm{IyM} / \mathrm{E}\end{array}$ & $\begin{array}{c}\text { CSC } \\
\text { IyM/E }\end{array}$ \\
\hline 1 & Sí/Sí & Sí/Sí & Sí/Sí & Sí/Sí & Sí/Sí & No/Sí & $\mathrm{No} / \mathrm{Sí}$ \\
\hline 2 & $\mathrm{No} / \mathrm{No}$ & Sí/Sí & $\mathrm{No} / \mathrm{No}$ & Sí/Sí & Sí/Sí & No/Sí & Sí/Sí \\
\hline 3 & No/Sí & Sí/Sí & No/Sí & $\mathrm{No} / \mathrm{No}$ & $\mathrm{No} / \mathrm{No}$ & No/Sí & Sí/No \\
\hline 4 & Sí/Sí & Sí/Sí & $\mathrm{No} / \mathrm{No}$ & Sí/Sí & Sí/Sí & No/Sí & Sí/Sí \\
\hline 5 & Sí/Sí & Sí/Sí & $\mathrm{No} / \mathrm{No}$ & $\mathrm{No} / \mathrm{No}$ & $\mathrm{No} / \mathrm{No}$ & No/Sí & No/Sí \\
\hline 6 & Sí/Sí & Sí/Sí & $\mathrm{No} / \mathrm{No}$ & No/Sí & Sí/Sí & No/Sí & No/Sí \\
\hline 7 & Sí/Sí & Sí/Sí & Sí/Sí & $\mathrm{No} / \mathrm{No}$ & Sí/Sí & Sí/Sí & No/Sí \\
\hline 8 & Sí/Sí & Sí/Sí & $\mathrm{No} / \mathrm{No}$ & No/Sí & No/Sí & No/Sí & No/Sí \\
\hline 9 & Sí/Sí & Sí/Sí & Sí/Sí & Sí/Sí & Sí/Sí & No/Sí & No/Sí \\
\hline 10 & No/Sí & Sí/Sí & $\mathrm{No} / \mathrm{No}$ & $\mathrm{No} / \mathrm{No}$ & $\mathrm{No} / \mathrm{No}$ & No/Sí & $\mathrm{No} / \mathrm{No}$ \\
\hline 11 & Sí/Sí & Sí/Sí & $\mathrm{No} / \mathrm{No}$ & $\mathrm{No} / \mathrm{No}$ & $\mathrm{No} / \mathrm{No}$ & No/Sí & $\mathrm{No} / \mathrm{No}$ \\
\hline 12 & Sí/Sí & Sí/Sí & $\mathrm{No} / \mathrm{No}$ & $\mathrm{No} / \mathrm{No}$ & $\mathrm{No} / \mathrm{No}$ & $\mathrm{No} / \mathrm{No}$ & $\mathrm{No} / \mathrm{No}$ \\
\hline 13 & $\mathrm{No} / \mathrm{No}$ & Sí/Sí & $\mathrm{No} / \mathrm{No}$ & $\mathrm{No} / \mathrm{No}$ & $\mathrm{No} / \mathrm{No}$ & $\mathrm{No} / \mathrm{No}$ & $\mathrm{No} / \mathrm{No}$ \\
\hline 14 & $\mathrm{No} / \mathrm{No}$ & Sí/Sí & $\mathrm{No} / \mathrm{No}$ & $\mathrm{No} / \mathrm{No}$ & $\mathrm{No} / \mathrm{No}$ & $\mathrm{No} / \mathrm{No}$ & $\mathrm{No} / \mathrm{No}$ \\
\hline 15 & $\mathrm{No} / \mathrm{No}$ & Sí/Sí & $\mathrm{No} / \mathrm{No}$ & $\mathrm{No} / \mathrm{No}$ & $\mathrm{No} / \mathrm{No}$ & No/Sí & $\mathrm{No} / \mathrm{No}$ \\
\hline 16 & Sí/Sí & Sí/Sí & $\mathrm{No} / \mathrm{No}$ & Sí/Sí & Sí/Sí & No/Sí & No/Sí \\
\hline 17 & Sí/Sí & Sí/Sí & $\mathrm{No} / \mathrm{No}$ & $\mathrm{No} / \mathrm{No}$ & Sí/Sí & No/Sí & Sí/Sí \\
\hline 18 & Sí/Sí & Sí/Sí & $\mathrm{No} / \mathrm{No}$ & $\mathrm{No} / \mathrm{No}$ & Sí/Sí & Sí/Sí & Sí/Sí \\
\hline 19 & Sí/Sí & Sí/Sí & Sí/Sí & $\mathrm{No} / \mathrm{No}$ & No/Sí & No/Sí & No/Sí \\
\hline 20 & No/Sí & Sí/Sí & Sí/Sí & $\mathrm{No} / \mathrm{No}$ & No/Sí & No/Sí & No/Sí \\
\hline 21 & Sí/Sí & Sí/Sí & $\mathrm{No} / \mathrm{No}$ & No/Sí & $\mathrm{No} / \mathrm{No}$ & $\mathrm{No} / \mathrm{No}$ & No/Sí \\
\hline 22 & Sí/Sí & Sí/Sí & $\mathrm{No} / \mathrm{No}$ & $\mathrm{No} / \mathrm{Sí}^{\prime}$ & No/Sí & No/Sí & $\mathrm{No} / \mathrm{No}$ \\
\hline 23 & No/Sí & Sí/Sí & $\mathrm{No} / \mathrm{No}$ & Sí/Sí & Sí/Sí & $\mathrm{No} / \mathrm{No}$ & No/Sí \\
\hline 24 & Sí/Sí & Sí/Sí & $\mathrm{No} / \mathrm{No}$ & No/Sí & No/Sí & $\mathrm{No} / \mathrm{No}$ & No/Sí \\
\hline 25 & Sí/Sí & Sí/Sí & $\mathrm{No} / \mathrm{No}$ & No/Sí & No/Sí & $\mathrm{No} / \mathrm{No}$ & No/Sí \\
\hline 26 & Sí/Sí & Sí/Sí & $\mathrm{No} / \mathrm{No}$ & $\mathrm{No} / \mathrm{Sí}$ & $\mathrm{No} / \mathrm{No}$ & $\mathrm{No} / \mathrm{No}$ & No/Sí \\
\hline 27 & Sí/Sí & Sí/Sí & $\mathrm{No} / \mathrm{No}$ & Sí/Sí & Sí/No & $\mathrm{No} / \mathrm{No}$ & Sí/Sí \\
\hline 28 & No/Sí & Sí/Sí & $\mathrm{No} / \mathrm{No}$ & Sí/Sí & Sí/Sí & $\mathrm{No} / \mathrm{No}$ & No/Sí \\
\hline 29 & Sí/Sí & Sí/Sí & Sí/Sí & $\mathrm{No} / \mathrm{No}$ & No/Sí & No/Sí & No/Sí \\
\hline 30 & Sí/Sí & No/Sí & Sí/Sí & $\mathrm{No} / \mathrm{No}$ & No/Sí & Sí/Sí & $\mathrm{No} / \mathrm{No}$ \\
\hline 31 & No/Sí & $\mathrm{No} / \mathrm{Sí}^{\prime}$ & $\mathrm{No} / \mathrm{No}$ & $\mathrm{No} / \mathrm{No}$ & $\mathrm{No} / \mathrm{No}$ & Sí/Sí & $\mathrm{No} / \mathrm{No}$ \\
\hline $\begin{array}{c}\% \\
\text { Acuerdo }\end{array}$ & 80.64 & 93.54 & 96.77 & 77.41 & 70.96 & 45.16 & 45.16 \\
\hline
\end{tabular}

$\overline{\overline{\text { Nota. } \text { Las casillas sombreadas representan una situación de acuerdo y las blancas de }}}$ desacuerdo. IyM = Investigador y maestros; $\mathrm{E}=$ Experto; $\mathrm{S}$ í = EAE propuesto como contribuyente al desarrollo de una competencia; No = EAE no propuesto como contribuyente al desarrollo de una competencia. 
En la Tabla 6.4 se muestra un conteo de las situaciones de acuerdo y desacuerdo, así como sus respectivas tasas.

Tabla 6.4. Conteo y porcentajes de acuerdos y desacuerdos

\begin{tabular}{ccccc}
\hline \hline & \multicolumn{2}{c}{ Acuerdo } & \multicolumn{2}{c}{ Desacuerdo } \\
\cline { 2 - 5 } & Sí/Sí & No/No & Sí/No & No/Sí \\
\hline \multirow{2}{*}{ Conteo } & 85 de 217 & 73 de 217 & 2 de 217 & 57 de 217 \\
& 158 de 217 & \multicolumn{2}{c}{59 de 217 } \\
$\%$ & 39.17 & 33.64 & 0.92 & 26,26 \\
& \multicolumn{2}{c}{72.81} & \multicolumn{2}{c}{27.18} \\
\hline \hline
\end{tabular}

Los EAE propuestos como contribuyentes al desarrollo de cada competencia por el investigador y los maestros fueron casi en su totalidad propuestos también por cada uno de los expertos. No obstante, estos consideraron que algunos EAE contribuían al desarrollo de mayor número de competencias que las indicadas por el investigador y los maestros. Por ello, aunque para preservar el carácter natural de la investigación —es decir, donde los maestros son los encargados de relacionar los EAE con las competenciasel análisis de los resultados se aplicó sobre la propuesta conjunta del investigador y los maestros, se quiso analizar si existían diferencias significativas al aplicar una y otra variante del instrumento. Para ello, se compararon los resultados obtenidos con ambas variantes del instrumento en uno de los grupos del último prototipo, concretamente en el Grupo 4 (Anexo 6.7), obteniéndose en todos los casos una correlación superior a .91 con p-valor $<.01$.

\subsubsection{Análisis cuantitativo}

A continuación, se presentan dos partes diferenciadas del análisis cuantitativo llevado a cabo. 


\subsubsection{Tratamiento del conjunto de datos numéricos procedente del análisis cualitativo}

Por último, se procedieron a tratar mediante estadística inferencial los datos numéricos obtenidos del análisis cualitativo, recurriéndose a la versión 26.0 del software estadístico IBM SPSS Statistics. Dependiendo del tamaño de la muestra, para evaluar la normalidad de la distribución de los datos se empleó la prueba de Kolmogorov-Smirnov o la prueba de Shapiro-Wilk, las cuales siempre arrojaron resultados de un p-valor $<.05$ significativo en las ocho variables, lo que indicó una violación de la suposición de normalidad. Los resultados de estas pruebas se muestran en las Tablas 6.5 y 6.6.

Tabla 6.5. Prueba de Kolmogorov-Smirnov para la muestra total

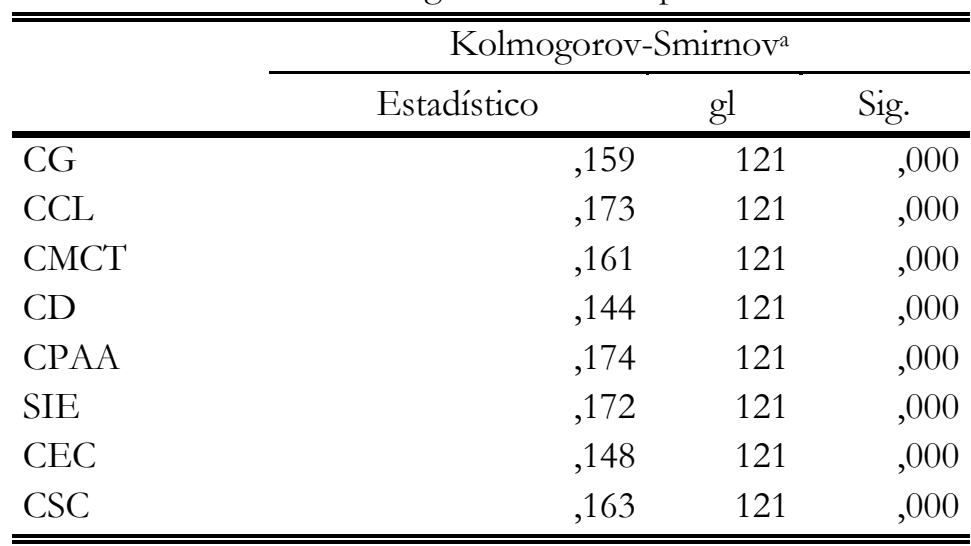

a. Corrección de significación de Lilliefors

Tabla 6.6. Prueba de Kolmogorov-Smirnov y Shapiro-Wilk para muestras segmentadas por prototipo

\begin{tabular}{|c|c|c|c|c|c|c|c|}
\hline & & \multicolumn{3}{|c|}{ Kolmogorov-Smirnova } & \multicolumn{3}{|c|}{ Shapiro-Wilk } \\
\hline & & Estadístico & gl & Sig. & Estadístico & gl & Sig. \\
\hline \multirow[t]{3}{*}{ CG } & Prototipo 1 & & & & ,811 & 20 & ,001 \\
\hline & Prototipo 2 & & & & ,872 & 41 & 000 \\
\hline & Prototipo 3 & , 166 & 60 &, 000 & & & \\
\hline \multirow[t]{3}{*}{$\overline{\mathrm{CCL}}$} & Prototipo 1 & & & & ,795 & 20 & ,001 \\
\hline & Prototipo 2 & & & & ,866 & 41 & 000 \\
\hline & Prototipo 3 & , 174 & 60 &, 000 & & & \\
\hline
\end{tabular}




\begin{tabular}{|c|c|c|c|c|c|c|c|}
\hline СMCT & $\begin{array}{l}\text { Prototipo } 1 \\
\text { Prototipo } 2 \\
\text { Prototipo } 3\end{array}$ & , 186 & 60 & ,000 & $\begin{array}{l}809 \\
862\end{array}$ & $\begin{array}{l}20 \\
41\end{array}$ & $\begin{array}{l}001 \\
000\end{array}$ \\
\hline $\mathrm{CD}$ & $\begin{array}{l}\text { Prototipo } 1 \\
\text { Prototipo } 2 \\
\text { Prototipo } 3\end{array}$ & ,186 & 60 & ,000 & $\begin{array}{l}\text {,813 } \\
901\end{array}$ & $\begin{array}{l}20 \\
41\end{array}$ & $\begin{array}{l}, 001 \\
002\end{array}$ \\
\hline CPAA & $\begin{array}{l}\text { Prototipo } 1 \\
\text { Prototipo } 2 \\
\text { Prototipo } 3\end{array}$ & ,188 & 60 & ,000 & $\begin{array}{l}\text {,810 } \\
872\end{array}$ & $\begin{array}{l}20 \\
41\end{array}$ & $\begin{array}{l}\text {,001 } \\
\text { 000 }\end{array}$ \\
\hline SIE & $\begin{array}{l}\text { Prototipo } 1 \\
\text { Prototipo } 2 \\
\text { Prototipo } 3\end{array}$ & ,181 & 60 & ,000 & $\begin{array}{l}, 826 \\
, 872\end{array}$ & $\begin{array}{l}20 \\
41\end{array}$ & $\begin{array}{l}\text {,002 } \\
000\end{array}$ \\
\hline CEC & $\begin{array}{l}\text { Prototipo } 1 \\
\text { Prototipo } 2 \\
\text { Prototipo } 3\end{array}$ & 191 & 60 &, 000 & $\begin{array}{l}\text {,872 } \\
899\end{array}$ & $\begin{array}{l}20 \\
41\end{array}$ & $\begin{array}{l}\text {,013 } \\
002\end{array}$ \\
\hline $\mathrm{CSC}$ & $\begin{array}{l}\text { Prototipo } 1 \\
\text { Prototipo } 2 \\
\text { Prototipo } 3\end{array}$ & ,183 & 60 & 000 & $\begin{array}{l}\text {,828 } \\
, 859\end{array}$ & $\begin{array}{l}20 \\
41\end{array}$ & $\begin{array}{l}, 002 \\
, 000\end{array}$ \\
\hline
\end{tabular}

a. Corrección de significación de Lilliefors

Por lo tanto, se emplearon estadísticos no paramétricos para el análisis de datos. Concretamente se utilizó la prueba U de Mann-Withney para comparar entre géneros tanto dentro de los prototipos como con la muestra total y la prueba $\mathrm{H}$ de Kruskal-Wallis para comparar entre prototipos y entre grupos con la muestra total.

\subsubsection{Análisis del instrumento de evaluación de actitudes hacia la ciencia e intenciones hacia la ciencia, la ingeniería y su conjunto}

Para determinar la influencia de la implementación de una UD STEAM en el plano actitudinal del alumnado de Educación Primaria, los datos procedentes de cuatro constructos — actitudes hacia la ciencia, intención hacia la ciencia, intención hacia la ingeniería e intención hacia STEM - de la adaptación al español del instrumento de evaluación de actitudes hacia la ciencia BRAINS, se trataron mediante estadística descriptiva e inferencial. Para su vaciado y 
análisis se recurrió a la versión 26.0 del software estadístico IBM SPSS Statistics. Dado el tamaño de la muestra, para evaluar la distribución de estos datos se empleó la prueba de Kolmogorov-Smirnov, que arrojó resultados de un p-valor $<.05$ significativos en los cuatro constructos. Los resultados de esta prueba se muestran en la Tabla 6.7.

Tabla 6.7. Prueba de Kolmogorov-Smirnov para la muestra total

\begin{tabular}{|c|c|c|c|}
\hline & \multicolumn{3}{|c|}{ Kolmogorov-Smirnova } \\
\hline & Estadístico & $\mathrm{gl}$ & Sig. \\
\hline Actitudes ciencia & ,142 & 117 &, 000 \\
\hline Intención ciencia & 131 & 117 & ,000 \\
\hline Intención ingeniería & 169 & 117 & ,000 \\
\hline Intención STEM & 091 & 117 & ,018 \\
\hline
\end{tabular}

a. Corrección de significación de Lilliefors

Por tanto, se emplearon nuevamente estadísticos no paramétricos para el análisis de datos: la prueba U de Mann-Whitney para comparar entre género y la prueba $\mathrm{H}$ de Kruskal-Wallis para comparar entre prototipos y grupos.

En cuanto a la comparación de los resultados de la evaluación de actitudes hacia la ciencia e intenciones hacia la ciencia, la ingeniería y su conjunto entre quinto y sexto curso, dado el tamaño de la muestra, para evaluar la distribución de los datos se empleó la prueba de Kolmogorov-Smirnov, la cual arrojó resultados de un p-valor $<.05$ significativo en los cuatro constructos, lo que indicó una violación de la suposición de normalidad. Los resultados de esta prueba se muestran en la Tabla 6.8.

Tabla 6.8. Prueba de Kolmogorov-Smirnov para la muestra agrupada de quinto y sexto

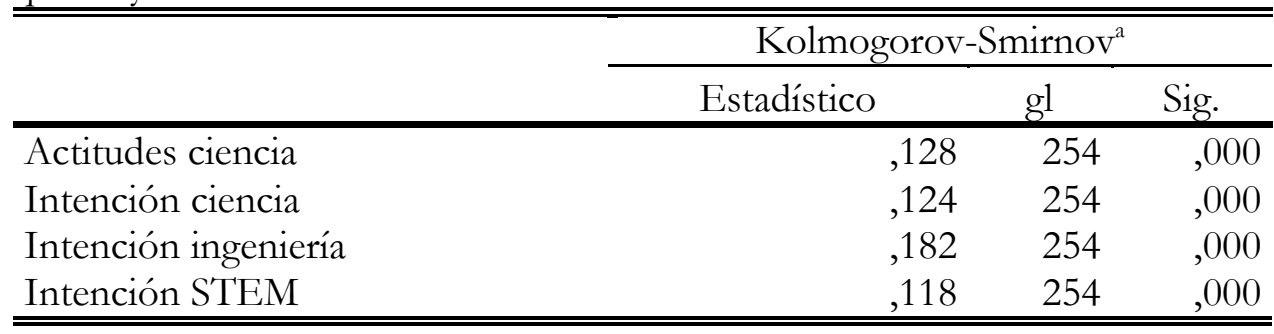

a. Corrección de significación de Lilliefors 
Por lo tanto, se emplearon estadísticos no paramétricos para el análisis de datos. Concretamente se utilizó la prueba U de Mann-Whitney para comparar entre los dos grupos y la $\mathrm{r}$ de Rosenthal para determinar el tamaño del efecto de las diferencias.

\subsubsection{Análisis de métodos mixtos}

Finalmente, para determinar si existía alguna relación entre determinado desarrollo competencial escolar — concretamente de la CMCT- y las Actitudes hacia la ciencia e Intenciones hacia la ciencia, la ingeniería y su conjunto en el marco de la implementación de la UD STEAM y, de acuerdo con el tipo de diseño de métodos mixtos utilizado, se procedieron a fusionar y comparar algunos datos procedentes del análisis cualitativo y cuantitativo. Para ello, se utilizó estadística descriptiva, concretamente se utilizó una comparación de las medias y las desviaciones estándar de las variables.

Cabe destacar que la concepción del constructo competencial que ha sido adoptada en esta tesis, y que aparece detallada en el Capítulo 2, incluye la dimensión de las actitudes, por lo que se esperaba la existencia de algún tipo de relación entre la tendencia del desarrollo competencial escolar —en este caso de la CMCT - y la tendencia de los constructos relacionados con las actitudes e intenciones que se han evaluado.

Una síntesis de toda la información del diseño metodológico presentada en este capítulo se recoge en la Figura 6.3. 


\section{-Notas de campo \\ -Cuaderno de campo del alumnado \\ -Calificaciones de la escala de observación}

-Datos numéricos deducidos del análisis cualitativo -Adaptación al español del instrumento BRAINS
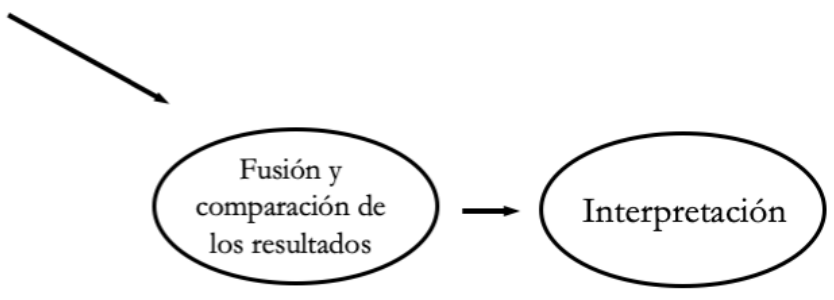

Figura 6.3. Síntesis de la información del diseño metodológico creado enmarcada en el diagrama del diseño de métodos mixtos paralelo convergente $Q U A L+$ quan empleado en la investigación. 


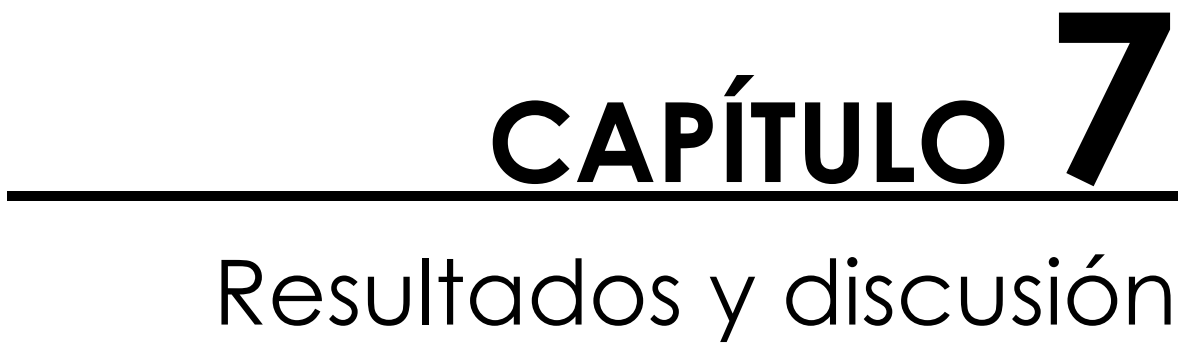



L

a progresiva ampliación de la muestra de alumnado desde el primer prototipo - producto del investigador- hacia los sucesivos productos de la reflexión conjunta, basada en las evidencias disponibles, del investigador y de los profesionales de la práctica educativa - permitió la mejora paulatina de la propuesta didáctica. En este capítulo se presentan las evidencias de esta mejora en términos de desarrollo competencial escolar del alumnado y de actitudes e intenciones hacia la ciencia y la ingeniería. En primer lugar, aparecen los resultados derivados de los análisis cualitativo y cuantitativo de cada prototipo para después pasar a mostrar los resultados de los análisis cualitativo, cuantitativo y mixto del total de la muestra. El capítulo finaliza con la discusión de estos resultados.

Indicar que este capítulo contiene información procedente de algunos trabajos previos (Ortiz-Revilla, Greca y Adúriz-Bravo, 2018a; Ortiz-Revilla, Greca y Meneses Villagrá, 2018, 2019).

\subsection{Resultados del Prototipo 1}

\subsubsection{Resultados del análisis cualitativo}

\subsubsection{Resultados de la interpretación de las notas de campo}

De la interpretación de las notas de campo obtenidas a través de la observación participante llevada a cabo entre el investigador y el primer maestro inmerso en el contexto de enseñanza-aprendizaje emergieron cinco categorías de información: 1) Modificaciones generales, 2) Modificaciones relativas a contenidos de Matemáticas, 3) Modificaciones relativas a contenidos de Ciencias de la Naturaleza, 4) Modificaciones relativas a contenidos de Educación Plástica y 5) Modificaciones relativas al diseño de ingeniería.

En la Tabla 7.1 se muestran algunos ejemplos de notas de campo para cada una de las categorías: 
Tabla 7.1. Ejemplos de notas de campo para cada categoría

\begin{tabular}{ll}
\hline Categoría & $\begin{array}{l}\text { Ejemplo observado y recogido como nota de } \\
\text { campo }\end{array}$ \\
\hline 1) Modificaciones generales & - La cantidad de hojas del cuaderno de campo es \\
& escasa. \\
& - El tiempo de dedicado a las ideas previas se hace \\
& demasiado largo. Pasada una cierta cantidad de \\
& tiempo el alumnado comienza a proponer ideas \\
& sin demasiada reflexión. \\
& - Algunas normas de trabajo no son \\
& comprendidas bien por el alumnado.
\end{tabular}
2) Modificaciones relativas a - El alumnado tiene problemas a la hora de contenidos de Matemáticas construir los gráficos de manera centrada.
- Apenas ha habido reflexión en la actividad del gráfico poligonal.
- El tiempo de algunas sesiones es demasiado escaso y los maestros se apresuran por acabar las actividades.
3) Modificaciones relativas a - El alumnado se limita a copiar de internet una contenidos de Ciencias de determinada cantidad de información que la Naturaleza apenas entiende.
- Existen problemas a la hora de manipular los cables en la actividad de los circuitos.
- En la actividad del recuento de bombillas no queda clara la organización de dicho recuento.
4) Modificaciones relativas a - El alumnado demora demasiado tiempo en contenidos de Educación representar la composición natural en su Plástica cuaderno para después colorearla.
- Conviene aumentar la reflexión de la actividad experimental del color.
- Al colorear a menudo se pierde la noción de color frío y cálido.
5) Modificaciones relativas al - Se consume tiempo innecesario en recordar y diseño de ingeniería volver a explicar al alumnado lo planteado en el diseño de ingeniería en la sesión anterior.
- Los dibujos del prototipo final a menudo tienen errores de proporción.
- Conviene reflexionar más pausadamente sobre las razones de los dibujos del prototipo final.


Estas categorías, junto con la información obtenida de la evaluación competencial escolar y de las actitudes e intenciones hacia la ciencia, la ingeniería y su conjunto, dieron lugar a un conjunto de mejoras que fueron incorporadas a la programación del siguiente Prototipo 2 de la UD, que aparecen en la subsección 7.1.3.

\subsubsection{Resultados de la evaluación competencial escolar}

Tras integrar en el instrumento de evaluación competencial escolar las calificaciones otorgadas por el maestro a todas las actividades realizadas por el alumnado, se determinó el nivel competencial escolar alcanzado por el alumnado del Grupo 1, que siguieron el Prototipo 1 de la UD. En la Tabla 7.2 se muestran los estadísticos descriptivos correspondientes a su desarrollo competencial escolar. Aclarar que el máximo puntaje a alcanzar en la CG es de 379, en la CCL de 102, en la CMCT de 127, en la CD de 18, en la CPAA de 29, en el SIE de 53, en la CEC de 21 y en las CSC de 29.

Tabla 7.2. Estadísticos descriptivos de la evaluación competencial en el Prototipo 1

\begin{tabular}{crrrrrrrrr}
\hline \hline Prototipo & \multicolumn{1}{c}{ CG } & CCL & CMCT & CD & CPAA & SIE & CEC & CSC \\
\hline P1 & $\mathrm{n}$ & 20 & 20 & 20 & 20 & 20 & 20 & 20 & 20 \\
& $M$ & 293,225 & 79,675 & 100,225 & 12,675 & 22,000 & 40,075 & 16,275 & 22,300 \\
& $D E$ & 76,736 & 20,044 & 24,432 & 4,168 & 6,691 & 11,657 & 3,906 & 6,218 \\
\hline \hline
\end{tabular}

Derivados de estos datos se calculó una serie de porcentajes de consecución competencial que a su vez permitieron obtener el nivel competencial escolar alcanzado por el alumnado del grupo (Tabla 7.3), considerándose cuatro niveles de desarrollo correspondientes a los cuartiles:

- Nivel 1: del 0\% al 25\%.

- Nivel 2: del 26\% al $50 \%$.

- Nivel 3: del 51\% al 75\%.

- Nivel 4: del 76\% al 100\%. 
Tabla 7.3. Porcentajes y niveles de consecución competencial en el Prototipo 1

\begin{tabular}{lrrrrrrrrr}
\hline \hline Prototipo & CG & CCL & CMCT & CD & CPAA & SIE & CEC & CSC \\
\hline P1 & $\mathrm{n}$ & 20 & 20 & 20 & 20 & 20 & 20 & 20 & 20 \\
& $\%$ & 77,36 & 78,03 & 78,89 & 70 & 75,86 & 75,47 & 77,14 & 76,89 \\
& 4 & 4 & 4 & 3 & 4 & 4 & 4 & 4 \\
\hline \hline
\end{tabular}

Se puede observar que, a excepción de la CD, el grupo se encuentra al finalizar la UD en el mayor nivel de desarrollo competencial escolar de acuerdo con dicha UD.

\subsubsection{Resultados del análisis cuantitativo}

\subsubsection{Resultados del tratamiento del conjunto de datos numéricos procedente del análisis cualitativo}

Controlando la variable género, la prueba U de Mann-Whitney reveló una inexistencia de diferencias significativas tanto en la CG como en todas las competencias clave - CCL, CMCT, CD, CPAA, SIE, CEC y CSC-. En la Tabla 7.4 se muestran los resultados de esta prueba.

Tabla 7.4. Prueba U de Mann Whitney controlando la variable género en el Prototipo 1

\begin{tabular}{lrrrrrrrr}
\hline \hline & CG & CCL & CMCT & CD & CPAA & SIE & CEC & CSC \\
\hline U de Mann- & 29,000 & 28,000 & 28,000 & 24,000 & 25,000 & 24,000 & 27,500 & 28,500 \\
Whitney & & & & & & & & \\
Z & $-1,558$ & $-1,637$ & $-1,634$ & $-1,949$ & $-1,867$ & $-1,942$ & $-1,675$ & $-1,607$ \\
Sig. &, 119 &, 102 &, 102 &, 051 &, 062 &, 052 &, 094 &, 108 \\
asintótica(bilateral) & & & & & & & & \\
\hline \hline
\end{tabular}

a. Prototipo $=$ Prototipo 1

b. Variable de agrupación: Género 


\subsubsection{Resultados de la evaluación de actitudes hacia la ciencia e intenciones hacia la ciencia, la ingeniería y su conjunto}

En cuanto al análisis de actitudes e intenciones — según la medición del instrumento BRAINS - del alumnado del Grupo 1, que siguió el Prototipo 1 de la UD, en la Tabla 7.5 se muestran los estadísticos descriptivos correspondientes a los cuatro constructos analizados correspondientes con las actitudes hacia la ciencia y las intenciones hacia la ciencia y la ingeniería, así como las intenciones hacia el conjunto de ellas. Recordar que los constructos de «Intención» estudian la intención de continuar ciencias o ingeniería, ya sea a través de futuras asignaturas o de carreras universitarias. En esta tesis, siguiendo el instrumento original, se emplea para ello la denominación de Intención hacia la ciencia, Intención hacia la ingeniería e Intención hacia STEM.

Tabla 7.5. Estadísticos descriptivos de las actitudes e intenciones en el Prototipo 1

\begin{tabular}{lrrrr}
\hline \hline & Actitudes ciencia & Intención ciencia & Intención ingeniería & Intención STEM \\
\hline $\mathrm{n}$ & 18 & 18 & 18 & 18 \\
$M$ & 3,815 & 3,019 & 3,204 & 3,080 \\
$\mathrm{DE}$ &, 688 &, 536 &, 998 &, 491 \\
\hline \hline
\end{tabular}

a. Prototipo $=1$

Estos valores implican la existencia de altas y positivas actitudes hacia la ciencia y positivas hacia la intención de continuar estudios científicotecnológicos.

\subsubsection{Mejoras para el Prototipo 2 de la UD derivadas de los resultados obtenidos}

Las principales modificaciones en la programación del Prototipo 2 de la UD estuvieron relacionadas con la organización de las actividades, la dificultad percibida en el alumnado para interpretar determinados fragmentos de la propuesta y la detección de carencias en el desarrollo de determinadas dimensiones competenciales, por ejemplo, la solvencia comunicativa. Se muestran con detalle a continuación. 
1) Modificaciones generales:

- El mismo alumnado acordará los colores de cada grupo en consenso.

- Se llevarán a cabo pequeñas modificaciones de concreción de dos normas de trabajo.

- Se ampliará la extensión del cuaderno de campo del alumnado.

- En lugar de comenzar a realizar la presentación de diapositivas como deber, esta actividad se convertirá en preparar un boceto preliminar. Así, en la sesión de continuación de las presentaciones, cada grupo construirá la presentación de diapositivas en el mismo ordenador y basándose en el boceto preparado en casa. De esta manera, se evitará que el alumnado tenga que realizar las diapositivas individualmente y después unirlas en un mismo documento.

- Se modificará la pregunta tres del examen convirtiéndola en afirmativa.

- En las fichas, se hará hincapié en que las respuestas estén fundamentadas y no se limiten a palabras sueltas.

- Los momentos dedicados a las ideas previas serán más breves debido a que cuando se extienden, se tiende a repetir información y se demora tiempo.

- Durante la explicación de la realización de las presentaciones, se comentará al alumnado que en el momento de la exposición no se puede limitar a leer, sino conformar un relato que demuestre tener una idea más amplia del tema que presenta.

- Aunque la explicación de la realización de las presentaciones esté colocada en una sesión, se comentará con el maestro la posibilidad de hacerlo en otro momento, ya que es escaso el tiempo en la sesión y tampoco merece la pena incorporar otra sesión más para ello.

2) Modificaciones relativas a contenidos de matemáticas:

- Los gráficos de barras y el gráfico poligonal se construirán en hojas cuadriculadas. Se hará hincapié en que las marcas de graduación de los ejes deben estar siempre a la misma distancia.

- En el problema del gráfico poligonal, se añadirá que el alumnado realice una pequeña interpretación.

- Se dividirá la antigua sesión Matemáticas I en dos nuevas sesiones, ya que el tiempo se queda escaso. 
- Se dividirá la antigua sesión Matemáticas III en dos nuevas sesiones, ya que el tiempo se queda escaso.

- Para la realización de los gráficos de sectores se aclarará que se deben indicar los porcentajes. No obstante, se otorgará libertad a cada maestro para que lo realice de la manera que considere oportuna.

- Debido a problemas con el funcionamiento de los ordenadores del alumnado, la realización de la tabla de datos la llevará a cabo el maestro en su ordenador y el alumnado interactuará en el proceso.

- Durante la realización de los gráficos se explicarán las funciones que tiene cada tipo, para así poder responder mejor a la pregunta correspondiente de la prueba escrita.

- En los gráficos sectoriales se incorporará la realización de una leyenda con colores.

3) Modificaciones relativas a contenidos de Ciencias de la Naturaleza:

- En la tarea de búsqueda de información en internet se solicitará al alumnado que las ideas que apunte en su cuaderno sea capaz de entenderlas y explicarlas. Además, se restringirá la extensión a una cara como máximo. Todo esto ayudará a discernir información relevante primer EAE de la parte de Ciencias de la Naturaleza-. No obstante, se dará lugar a expresar dudas encontradas en la información buscada.

- En vez de que el alumnado apunte las ideas a la vez que construye las explicaciones científicas con el maestro, se añadirá como deber que realice un resumen de cada explicación —electricidad y electricidad estática, corriente eléctrica, magnetismo y electromagnetismo- en un máximo de una cara, con el objetivo de sintetizar la información más relevante y con unas pautas más claras por parte del maestro.

- Se dividirá la sesión de explicación científica de la electrostática y la corriente eléctrica en dos nuevas sesiones incorporadas a continuación de sus respectivos experimentos. De esta manera, además de subsanar la falta de tiempo, resultará más coherente el hilo conductor.

- En la parte del trabajo de los circuitos en serie y paralelo, se acortarán los cables secundarios para facilitar su manipulación.

- Se dividirá la sesión de magnetismo y electromagnetismo en dos nuevas sesiones, una para los experimentos y otra para la explicación científica, ya que el tiempo inicialmente previsto es escaso. 
- En la actividad del recuento del tipo de bombillas que cada alumno tiene en su casa, se solicitará que se recojan los datos en una pequeña tabla.

4) Modificaciones relativas a contenidos de Educación Plástica:

- Se reducirá el número de experimentos de la ficha del color y se agregará la cuestión «ipor qué?» después de preguntar por el tipo de bombilla más adecuada para iluminar la sala de estudio.

- Durante la realización de la composición pictórica con colores cálidos y fríos, el maestro presentará ambas gamas en la pizarra digital.

- Se realizará una nueva ficha con dos ilustraciones para trabajar los colores fríos y cálidos en vez de realizar la composición con objetos de la clase.

5) Modificaciones relativas al diseño de ingeniería:

- La redefinición del problema y la recopilación de los resultados claves pasará a la siguiente sesión para que todo el proceso de ingeniería quede iniciado en la misma sesión, siendo más coherente realizar la explicación justo antes de comenzar a trabajar sobre el método.

- En el dibujo del prototipo, se añadirá la pauta de que esté proporcionado. Para facilitarlo, se añadirá una escala al dibujo del prototipo $1 \mathrm{~m})$.

- Se solicitará al alumnado que conforme una explicación final después del dibujo del prototipo, comentando lo que ha creado.

\subsection{Resultados del Prototipo 2}

\subsubsection{Resultados del análisis cualitativo}

\subsubsection{Resultados de la interpretación de las notas de campo}

Tras la implementación del Prototipo 2 de la UD se volvió a realizar una interpretación conjunta de las notas de campo, esta vez llevaba a cabo entre el investigador, los dos maestros de los grupos que siguieron el Prototipo 2 y el maestro del grupo que siguió el Prototipo 1. Se utilizaron las mismas categorías que en la primera ocasión, pero el número de problemas detectados fue menor, 
centrándose principalmente en aspectos de temporalización y de la autonomía de trabajo del alumnado.

Esta interpretación, junto con la información obtenida de la evaluación competencial escolar y de las actitudes hacia la ciencia e intenciones hacia la ciencia, la ingeniería y su conjunto, determinó un conjunto de mejoras que fueron incorporadas a la programación del siguiente Prototipo 3 de la UD, que aparecen en la subsección 7.2.3. Dado que en esta ocasión fueron muchas menos las carencias detectadas, también lo fueron las mejoras propuestas para la programación del prototipo final de la UD.

\subsubsection{Resultados de la evaluación competencial escolar}

Después de una nueva integración en el instrumento de evaluación competencial escolar de las calificaciones otorgadas por dos maestros a las distintas actividades realizadas por el alumnado, se determinó el nivel competencial escolar alcanzado por el alumnado de los dos grupos que siguieron el Prototipo 2 de UD. En la Tabla 7.6 se muestran los estadísticos descriptivos correspondientes a su desarrollo competencial escolar.

Tabla 7.6. Estadísticos descriptivos de la evaluación competencial en el Prototipo 2

\begin{tabular}{|c|c|c|c|c|c|c|c|c|}
\hline Prototipo & CG & CCL & СMCT & CD & СРАA & SIE & CEC & CSC \\
\hline P2 & 41 & 41 & 41 & 41 & 41 & 41 & 41 & 41 \\
\hline$M$ & 315,488 & 85,378 & 107,024 & 14,159 & 23,854 & 43,720 & 17,500 & 24,098 \\
\hline$D E$ & 56,829 & 15,253 & 18,448 & 3,372 & 4,675 & 8,346 & 2,979 & 4,277 \\
\hline
\end{tabular}

Derivados de estos datos se calcularon de nuevo los porcentajes de consecución competencial que a su vez permitieron obtener el nivel competencial escolar alcanzado por el alumnado de los grupos (Tabla 7.7). 
Tabla 7.7. Porcentajes y niveles de consecución competencial en el Prototipo 2

\begin{tabular}{lrrrrrrrrr}
\hline \hline Prototipo & CG & CCL & CMCT & CD & CPAA & SIE & CEC & CSC \\
\hline P2 & $\mathrm{n}$ & 41 & 41 & 41 & 41 & 41 & 41 & 41 & 41 \\
$\%$ & 83,21 & 83,62 & 84,25 & 78,33 & 82,06 & 82,45 & 83,33 & 82,75 \\
Nivel & 4 & 4 & 4 & 4 & 4 & 4 & 4 & 4 \\
\hline \hline
\end{tabular}

Se puede observar que la media del nivel de consecución competencial del alumnado de los grupos que siguieron el Prototipo 2 se encuentra en el nivel superior de desarrollo competencial escolar en todas las competencias evaluadas de acuerdo con esta UD.

\subsubsection{Resultados del análisis cuantitativo}

\subsubsection{Resultados del tratamiento del conjunto de datos numéricos procedente del análisis cualitativo}

Controlando la variable género, la prueba $U$ de Mann-Whitney reveló nuevamente la inexistencia de diferencias significativas tanto en la CG como en todas las competencias clave -CCL, CMCT, CD, CPAA, SIE, CEC y CSC_- En la Tabla 7.8 se muestran los resultados de esta prueba.

Tabla 7.8. Prueba U de Mann Whitney controlando la variable género en el

Prototipo 2

\begin{tabular}{lrrrrrrrr}
\hline \hline & CG & CCL & CMCT & CD & CPAA & SIE & CEC & CSC \\
\hline U de Mann-Whitney & 156,000 & 155,000 & 160,500 & 162,500 & 147,000 & 152,000 & 168,500 & 156,500 \\
Z & $-1,386$ & $-1,413$ & $-1,269$ & $-1,219$ & $-1,625$ & $-1,493$ & $-1,062$ & $-1,375$ \\
Sig. &, 166 &, 158 &, 205 &, 223 &, 104 &, 136 &, 288 &, 169 \\
asintótica(bilateral) & & & & & & & & \\
\hline \hline
\end{tabular}

a. Prototipo = Prototipo 2

b. Variable de agrupación: Género 


\subsubsection{Resultados de la evaluación de actitudes hacia la ciencia e intenciones hacia la ciencia, la ingeniería y su conjunto}

En cuanto al análisis de actitudes e intenciones del alumnado de los Grupos 2 y 3, que siguieron el Prototipo 2 de UD, en la Tabla 7.9 se muestran los estadísticos descriptivos correspondientes a los cuatro constructos analizados correspondientes con las actitudes hacia la ciencia y las intenciones hacia la ciencia y la ingeniería, así como las intenciones hacia el conjunto de ellas.

Tabla 7.9. Estadísticos descriptivos de las actitudes e intenciones en el Prototipo 2

\begin{tabular}{lrrrr}
\hline \hline & Actitudes ciencia & Intención ciencia & Intención ingeniería & Intención STEM \\
\hline $\mathrm{n}$ & 40 & 40 & 40 & 40 \\
$M$ & 4,321 & 3,317 & 2,892 & 3,175 \\
$\mathrm{DE}$ &, 561 &, 800 &, 779 &, 668 \\
\hline \hline
\end{tabular}

a. Prototipo $=2$

Se pueden observar nuevamente valores positivos y altos en las actitudes hacia la ciencia y positivos en la intención, aunque la intención hacia la ingeniería es más baja respecto a la obtenida en el Prototipo 1.

\subsubsection{Mejoras para el Prototipo 3 de la UD derivadas de los resultados obtenidos}

En esta ocasión, las principales modificaciones en la programación del Prototipo 3 de la UD ya no estuvieron relacionadas con la organización de las actividades, salvo una pequeña subsanación por motivos de tiempo, sino con cuestiones más específicas del enfoque de ciertas actividades. Se muestran con detalle a continuación.

1) Modificaciones generales:

- Se añadirá una sesión más para que el alumnado prepare la presentación de diapositivas debido a la falta de tiempo detectada.

2) Modificaciones relativas a contenidos de Matemáticas: 
- Después de la realización de los gráficos de sectores individual y grupal, además de responder a la pregunta ¿qué conviene hacer en mi casa?, se solicitará también respuesta a la cuestión ¿qué convendría hacer en la clase en general? Así, se obtendrá una visión más global del camino hacia el que se dirige el desarrollo tecnológico en las condiciones de vida actual — cuestión explícita en un EAE-.

3) Modificaciones relativas a contenidos de Ciencias de la Naturaleza:

- Por cuestiones de rigurosidad terminológica, en la ficha de los tipos de bombilla se cambiará la denominación de la variable «consumo» por «consumo en una hora», que es lo que realmente indica el número de vatios que se especifica en las cajas de bombillas que maneja el alumnado en la indagación.

4) Modificaciones relativas a contenidos de Educación Plástica:

- No se propondrán modificaciones relativas a esta área.

5) Modificaciones relativas al diseño de ingeniería:

- Se modificará la ficha de los requisitos del problema ingenieril con el objetivo de presentar un problema menos guiado, con más opción a que el alumnado piense y con más posibilidades de posterior propuesta de mejoras.

\subsection{Resultados del Prototipo 3}

\subsubsection{Resultados del análisis cualitativo}

\subsubsection{Resultados de la evaluación competencial escolar}

Tras el correspondiente proceso de integración en el instrumento de evaluación competencial escolar de las calificaciones otorgadas por tres maestros, se determinó el nivel competencial escolar alcanzado por el alumnado de los tres grupos que siguieron el Prototipo 3 de UD. En la Tabla 7.10 se muestran los estadísticos descriptivos correspondientes a su desarrollo competencial escolar. 
Tabla 7.10. Estadísticos descriptivos de la evaluación competencial en el Prototipo 3

\begin{tabular}{|c|c|c|c|c|c|c|c|c|}
\hline Prototipo & CG & CCL & CMCT & $\mathrm{CD}$ & СРАА & SIE & CEC & $\mathrm{CSC}$ \\
\hline P3 & 60 & 60 & 60 & 60 & 60 & 60 & 60 & 60 \\
\hline$M$ & 331,892 & 89,817 & 111,808 & 15,367 & 24,900 & 46,008 & 18,375 & 25,383 \\
\hline$D E$ & 47,895 & 12,619 & 15,406 & 2,581 & 4,523 & 7,432 & 2,293 & 3,761 \\
\hline
\end{tabular}

Como en ocasiones anteriores, derivados de estos datos se calcularon los porcentajes de consecución competencial que a su vez permitieron obtener el nivel competencial escolar alcanzado por el alumnado de los grupos (Tabla 7.11).

Tabla 7.11. Porcentajes y niveles de consecución competencial en el Prototipo 3

\begin{tabular}{|c|c|c|c|c|c|c|c|c|}
\hline Prototipo & CG & CCL & СMCT & $\mathrm{CD}$ & CPAA & $\overline{\mathrm{SIE}}$ & $\overline{\mathrm{CEC}}$ & $\mathrm{CSC}$ \\
\hline P3 & 60 & 60 & 60 & 60 & 60 & 60 & 60 & 60 \\
\hline$\%$ & 87,54 & 88,03 & 88,03 & 85 & 85,86 & 86,79 & 87,14 & 87,24 \\
\hline Nivel & 4 & 4 & 4 & 4 & 4 & 4 & 4 & 4 \\
\hline
\end{tabular}

En esta nueva ampliación de la muestra, se puede observar que la media del nivel de consecución competencial del alumnado de los grupos que siguieron el Prototipo 3 se sitúa, nuevamente, en el nivel superior de desarrollo competencial escolar en todas las competencias evaluadas de acuerdo con esta UD.

\subsubsection{Resultados del análisis cuantitativo}

\subsubsection{Resultados del tratamiento del conjunto de datos numéricos procedente del análisis cualitativo}

Controlando la variable género, la prueba U de Mann-Whitney reveló, en este tercer prototipo, la existencia de diferencias significativas tanto en la CG como en seis de las competencias clave (CCL, CMCT, CD, SIE, CEC y CSC). No se detectaron diferencias significativas derivadas del género en la CPAA. En la Tabla 7.12 se muestran los resultados de esta prueba. 
Tabla 7.12. Prueba U de Mann Whitney controlando la variable género en el Prototipo 3

\begin{tabular}{lrrrrrrrr}
\hline \hline & CG & CCL & CMCT & CD & CPAA & SIE & CEC & CSC \\
\hline U de Mann- & 296,000 & 296,000 & 300,500 & 285,000 & 324,500 & 297,000 & 310,000 & 295,500 \\
Whitney & & & & & & & & \\
Z & $-2,222$ & $-2,224$ & $-2,157$ & $-2,410$ & $-1,805$ & $-2,214$ & $-2,026$ & $-2,242$ \\
Sig. &, 026 &, 026 &, 031 &, 016 &, 071 &, 027 &, 043 &, 025 \\
asintótica(bilateral) & & & & & & & & \\
\hline \hline
\end{tabular}

a. Prototipo = Prototipo 3

b. Variable de agrupación: Género

En la Tabla 7.13 se muestran los estadísticos descriptivos que evidencian que todas las diferencias significativas fueron a favor de las chicas.

Tabla 7.13. Estadísticos descriptivos de la evaluación competencial por género en el Prototipo 3

\begin{tabular}{llrrrrrrr}
\hline \hline Género & \multicolumn{1}{c}{ CG } & CCL & CMCT & CD & SIE & CEC & \multicolumn{1}{c}{ CSC } \\
\hline Chico & $\mathrm{N}$ & 33 & 33 & 33 & 33 & 33 & 33 & 33 \\
& $M e$ & 337,000 & 92,000 & 115,500 & 16,000 & 47,500 & 18,500 & 26,000 \\
& $D E$ & 49,010 & 13,073 & 15,842 & 2,325 & 7,590 & 2,215 & 3,842 \\
& $M$ & 322,288 & 87,212 & 108,864 & 14,879 & 44,545 & 18,000 & 24,652 \\
\hline Chica & $\mathrm{N}$ & 27 & 27 & 27 & 27 & 27 & 27 & 27 \\
& $M e$ & 360,000 & 97,000 & 121,000 & 17,500 & 50,000 & 19,500 & 27,500 \\
& $D E$ & 44,598 & 11,483 & 14,327 & 2,790 & 6,958 & 2,345 & 3,525 \\
& $M$ & 343,630 & 93,000 & 115,407 & 15,963 & 47,796 & 18,833 & 26,278 \\
\hline \hline
\end{tabular}

a. Prototipo $=$ Prototipo 3

\subsubsection{Resultados de la evaluación de actitudes hacia la ciencia e intenciones hacia la ciencia, la ingeniería y su conjunto}

En cuanto al análisis de actitudes e intenciones de los grupos correspondientes al Prototipo3, en la Tabla 7.14 se muestran los estadísticos descriptivos 
correspondientes a los cuatro constructos analizados correspondientes con las actitudes hacia la ciencia y las intenciones hacia la ciencia y la ingeniería, así como las intenciones hacia el conjunto de ellas.

Tabla 7.14. Estadísticos descriptivos de las actitudes e intenciones en el Prototipo 3

\begin{tabular}{lrrrr}
\hline \hline & Actitudes ciencia & Intención ciencia & Intención ingeniería & Intención STEM \\
\hline $\mathrm{n}$ & 59 & 59 & 59 & 59 \\
$M$ & 4,167 & 3,116 & 3,056 & 3,096 \\
$D E$ &, 667 &, 934 &, 793 &, 789 \\
\hline \hline
\end{tabular}

a. Prototipo $=3$

Nuevamente, los valores son positivos y altos en las actitudes hacia la ciencia y positivos en los constructos relacionados con las intenciones.

\subsection{Resultados del total de la muestra}

\subsubsection{Resultados del análisis cualitativo}

\subsubsection{Resultados de la evaluación competencial escolar}

Tras el último proceso de integración, en este caso del total de calificaciones de la muestra, se determinó el nivel competencial escolar alcanzado por el alumnado de los seis grupos que siguieron cada uno de los tres prototipos de UD. En la Tabla 7.15 se muestran los estadísticos descriptivos correspondientes a su desarrollo competencial escolar.

Tabla 7.15. Estadísticos descriptivos de la evaluación competencial del total de la muestra

\begin{tabular}{|c|c|c|c|c|c|c|c|c|c|}
\hline & \multirow{2}{*}{$\frac{C G}{121}$} & \multirow{2}{*}{$\frac{\text { CCL }}{121}$} & \multirow{2}{*}{$\frac{\text { СМСТ }}{121}$} & \multirow{2}{*}{$\frac{\mathrm{CD}}{121}$} & \multirow{2}{*}{$\frac{\text { CPAA }}{121}$} & \multirow{2}{*}{$\frac{\mathrm{SIE}}{121}$} & \multirow{2}{*}{$\frac{\mathrm{CEC}}{121}$} & \multirow{2}{*}{$\frac{\mathrm{CSC}}{121}$} \\
\hline & $\frac{\text { Prototipo }}{\text { Total N }}$ & & & & & & & & \\
\hline & $M$ & 319,942 & 86,636 & 108,273 & 14,512 & 24,066 & 44,252 & 17,731 & 24,438 \\
\hline & $D E$ & 57,739 & 15,268 & 18,499 & 3,284 & 5,050 & 8,743 & 2,922 & 4,519 \\
\hline
\end{tabular}


Como en las tres ocasiones anteriores, derivados de estos datos se calcularon los porcentajes de consecución competencial y se obtuvo el nivel competencial escolar alcanzado por el alumnado de todos los grupos (Tabla 7.16).

Tabla 7.16. Porcentajes y niveles de consecución competencial en el total de la muestra

\begin{tabular}{lrrrrrrrrr}
\hline \hline Prototipo & CG & CCL & CMCT & CD & CPAA & SIE & CEC & CSC \\
\hline Total & $\mathrm{N}$ & 121 & 121 & 121 & 121 & 121 & 121 & 121 & 121 \\
& $\%$ & 84,40 & 84,90 & 85,19 & 80,55 & 82,75 & 83,39 & 84,28 & 84,13 \\
& Nivel & 4 & 4 & 4 & 4 & 4 & 4 & 4 & 4 \\
\hline \hline
\end{tabular}

Como era de esperar, teniendo en cuenta los resultados de los prototipos previos, el alumnado se ubica holgadamente en el nivel superior de desarrollo competencial escolar en todas las competencias de acuerdo con esta UD.

\subsubsection{Resultados del análisis cuantitativo}

\subsubsection{Resultados del tratamiento del conjunto de datos numéricos procedente del análisis cualitativo}

Controlando la variable género, la prueba U de Mann-Whitney reveló la existencia de diferencias significativas tanto en la CG como en todas las competencias clave (CCL, CMCT, CD, CPAA, SIE, CEC y CSC). En la Tabla 7.17 se muestran los resultados de esta prueba. 
Tabla 7.17. Prueba U de Mann-Whitney controlando la variable género en el total de la muestra

\begin{tabular}{lcrrrrrrr}
\hline \hline & CG & CCL & CMCT & CD & CPAA & SIE & CEC & CSC \\
\hline U de Mann- & 1290,000 & 1285,500 & 1290,000 & 1297,500 & 1295,500 & 1282,000 & 1346,500 & 1283,500 \\
Whitney & & & & & & & & \\
Z & $-2,733$ & $-2,758$ & $-2,734$ & $-2,705$ & $-2,710$ & $-2,778$ & $-2,447$ & $-2,775$ \\
Sig. &, 006 &, 006 &, 006 &, 007 &, 007 &, 005 &, 014 &, 006 \\
asintótica(bilateral) & & & & & & & & \\
\hline \hline
\end{tabular}

a. Variable de agrupación: Género

En la Tabla 7.18 se muestran los estadísticos descriptivos que evidencian que, al igual que en el Prototipo 3, todas las diferencias significativas fueron a favor de las chicas.

Tabla 7.18. Estadísticos descriptivos de la evaluación competencial por género en el total de la muestra

\begin{tabular}{llrrrrrrrr}
\hline \hline Género & \multicolumn{1}{c}{ CG } & CCL & CMCT & CD & CPAA & SIE & CEC & CSC \\
\hline Chico & $\mathrm{N}$ & 66 & 66 & 66 & 66 & 66 & 66 & 66 & 66 \\
& $M d$ & 329,750 & 89,500 & 110,750 & 15,000 & 25,250 & 46,500 & 18,000 & 25,250 \\
& DE & 65,6286 & 17,4432 & 21,1332 & 3,5636 & 5,8108 & 9,9141 & 3,2759 & 5,1669 \\
& $M$ & 306,250 & 83,008 & 103,894 & 13,803 & 22,826 & 42,174 & 17,121 & 23,364 \\
\hline Chica & $\mathrm{N}$ & 55 & 55 & 55 & 55 & 55 & 55 & 55 & 55 \\
& $M d$ & 347,000 & 93,500 & 116,500 & 16,000 & 27,000 & 49,000 & 19,000 & 26,500 \\
& $D E$ & 41,4726 & 10,7890 & 13,0906 & 2,7071 & 3,4489 & 6,3208 & 2,2482 & 3,1854 \\
& $M$ & 336,373 & 90,991 & 113,527 & 15,364 & 25,555 & 46,745 & 18,464 & 25,727 \\
\hline \hline
\end{tabular}

Según estos resultados, aunque todo el alumnado ha alcanzado un desarrollo competencial escolar alto en todas las competencias evaluadas, son las chicas las que, en su conjunto, alcanzan un mayor desarrollo competencial escolar. Aunque en la escuela las chicas suelen ser más aplicadas, lo que podría justificar esta diferencia, es necesario resaltar que en las evaluaciones Fin de etapa de $6^{\circ}$ de Primaria realizadas en el curso académico 2017-2018 por la Junta de Castilla y León $(\mathrm{JCyL})$, las chicas alcanzaron un nivel competencial menor que los chicos en ciencias y en matemáticas — con diferencias no 
significativas-. Esta situación es semejante a la mostrada por el Informe PISA 2015, en el cual se señala la existencia de diferencias por género en ciencias y matemáticas que, aunque pequeñas, muestran que en 33 países existe un mayor porcentaje de alumnos que de alumnas con un nivel excelente.

Controlando la variable prototipo, la prueba $\mathrm{H}$ de Kruskal-Wallis reveló la existencia de diferencias significativas tanto en la CG como en la CCL, CD, SIE y CSC. En la Tabla 7.19 se muestran los resultados de esta prueba.

Tabla 7.19. Prueba H de Kruskal-Wallis controlando la variable prototipo en el total de la muestra

\begin{tabular}{lrrrrrrrr}
\hline \hline & CG & CCL & CMCT & CD & CPAA & SIE & CEC & CSC \\
\hline H de Kruskal- & 7,277 & 7,493 & 5,956 & 10,234 & 5,542 & 7,321 & 5,989 & 7,180 \\
Wallis & & & & & & & & \\
gl & 2 & 2 & 2 & 2 & 2 & 2 & 2 & 2 \\
Sig. asintótica &, 026 &, 024 &, 051 &, 006 &, 063 &, 026 &, 050 &, 028 \\
\hline \hline
\end{tabular}

a. Prueba de Kruskal Wallis

b. Variable de agrupación: Prototipo

Las pruebas post hoc determinaron que estas diferencias significativas se encontraban en los casos de la CG $(p=.038)$, la CCL $(p=.031)$, la CD ( $p=$ $.006)$ y el SIE $(p=.037)$ entre el Prototipo 1 y el Prototipo 3 , a favor del último. En el caso de las CSC las pruebas post hoc no permitieron detectar diferencias significativas entre las parejas de prototipos. Las diferencias en el desarrollo competencial escolar entre el alumnado que siguió los diferentes prototipos eran esperadas, dado que el planteamiento del paradigma metodológico de investigación de diseño utilizado se basa en la mejora progresiva, a partir de la puesta en práctica de los sucesivos prototipos. De hecho, se esperaban diferencias mayores entre el Prototipo 1 y el Prototipo 3.

En particular, se destaca que las mejoras introducidas después del Prototipo 1 incidieron particularmente en aspectos relacionados con la CCL y la CD. Por ejemplo, en las exposiciones del alumnado se puso énfasis en que no se limitara a leer lo que tenía escrito, sino que conformara un relato que demostrara manejar una idea más amplia del tema que presentaba; en la tarea de búsqueda de información en internet se indicó al alumnado que las ideas que apuntara en su cuaderno fuera capaz de entenderlas y explicarlas, estableciendo 
una extensión máxima; o, en vez de que el alumnado apuntara las ideas a la vez que construía las explicaciones científicas con el maestro, tuviera como deber realizar un resumen de cada explicación, con una extensión máxima. Estas mejoras se mantienen en el Prototipo 3, donde algunas de las modificaciones introducidas incidían en el SIE, por ejemplo, el hecho de que el problema ingenieril fuera presentado menos guiado, con más opción a que el alumnado pensara y con más posibilidades de posterior propuesta de mejoras. Obviamente, esto ha incidió en un aumento de la CG.

En las Figuras 7.1, 7.2, 7.3, 7.4 y 7.5 se presentan los diagramas de cajas y bigotes y los gráficos de nodos correspondientes a estos casos. Aclarar que, en los gráficos de nodos, cada uno de los nodos representa un prototipo y cada una de las líneas el contraste realizado. Así, las líneas amarillas simbolizan contrastes que han resultado significativos y las negras no significativos. Los valores numéricos se corresponden con los rangos medios.
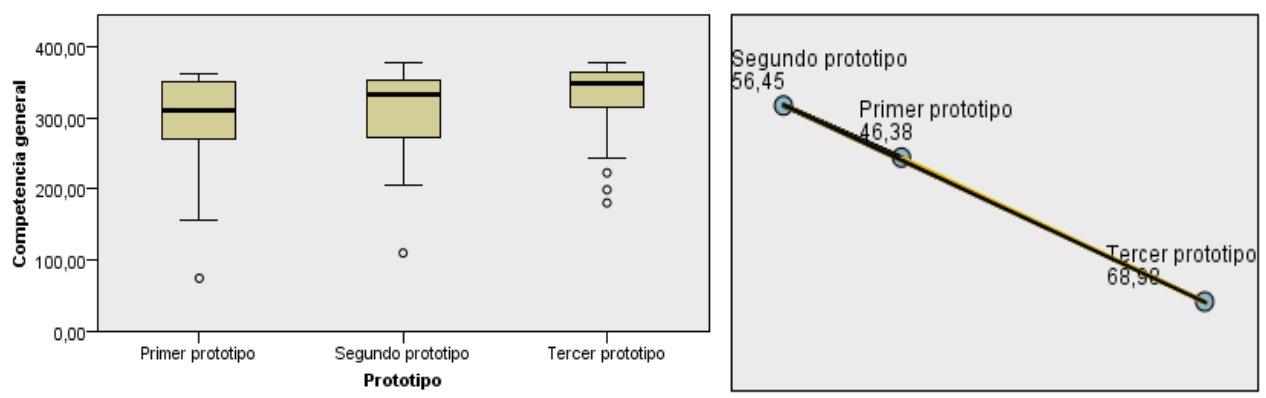

Figura 7.1. Diagrama de cajas y bigotes y gráfico de nodos correspondientes al caso de la CG. 

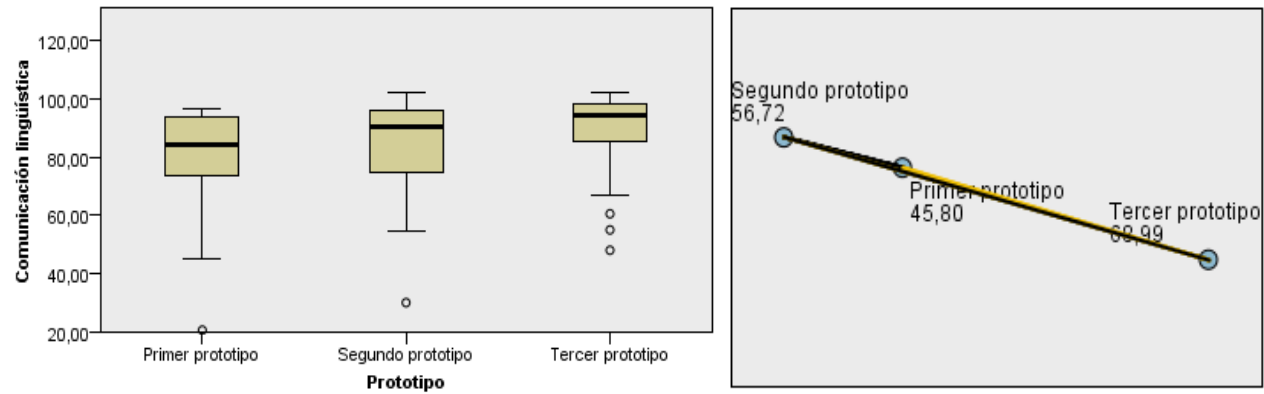

Figura 7.2. Diagrama de cajas y bigotes y gráfico de nodos correspondientes al caso de la CCL.
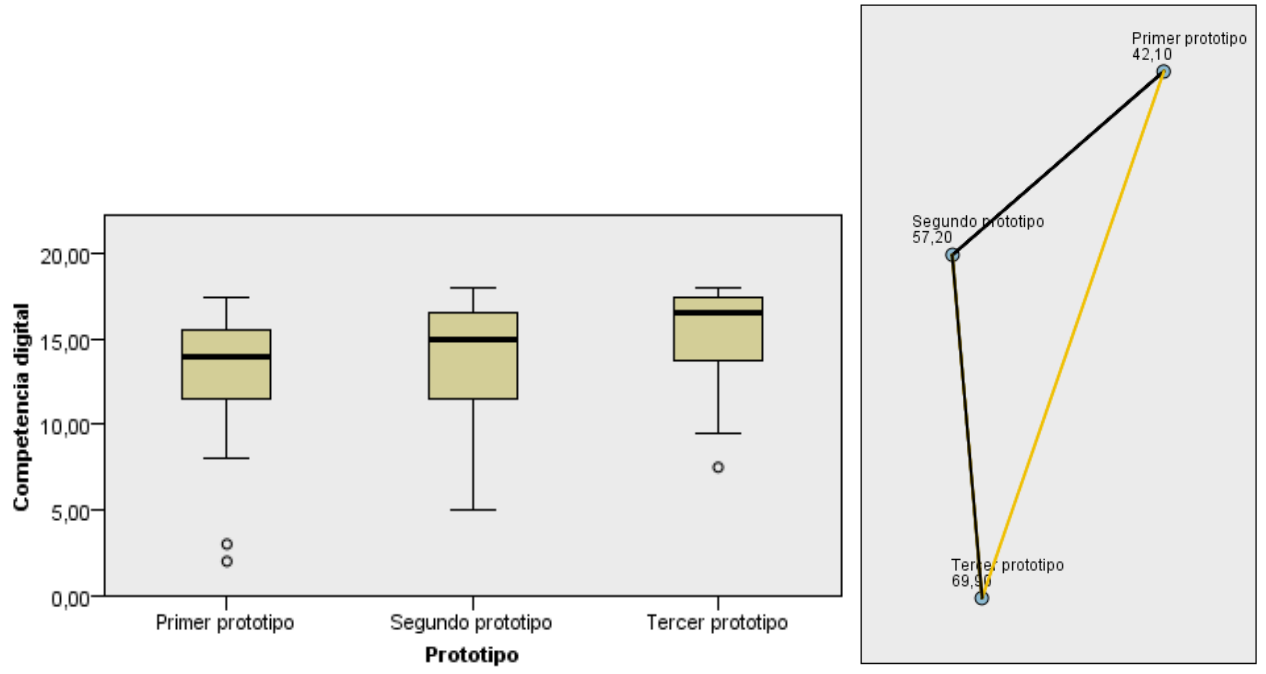

Figura 7.3. Diagrama de cajas y bigotes y gráfico de nodos correspondientes al caso de la CD. 

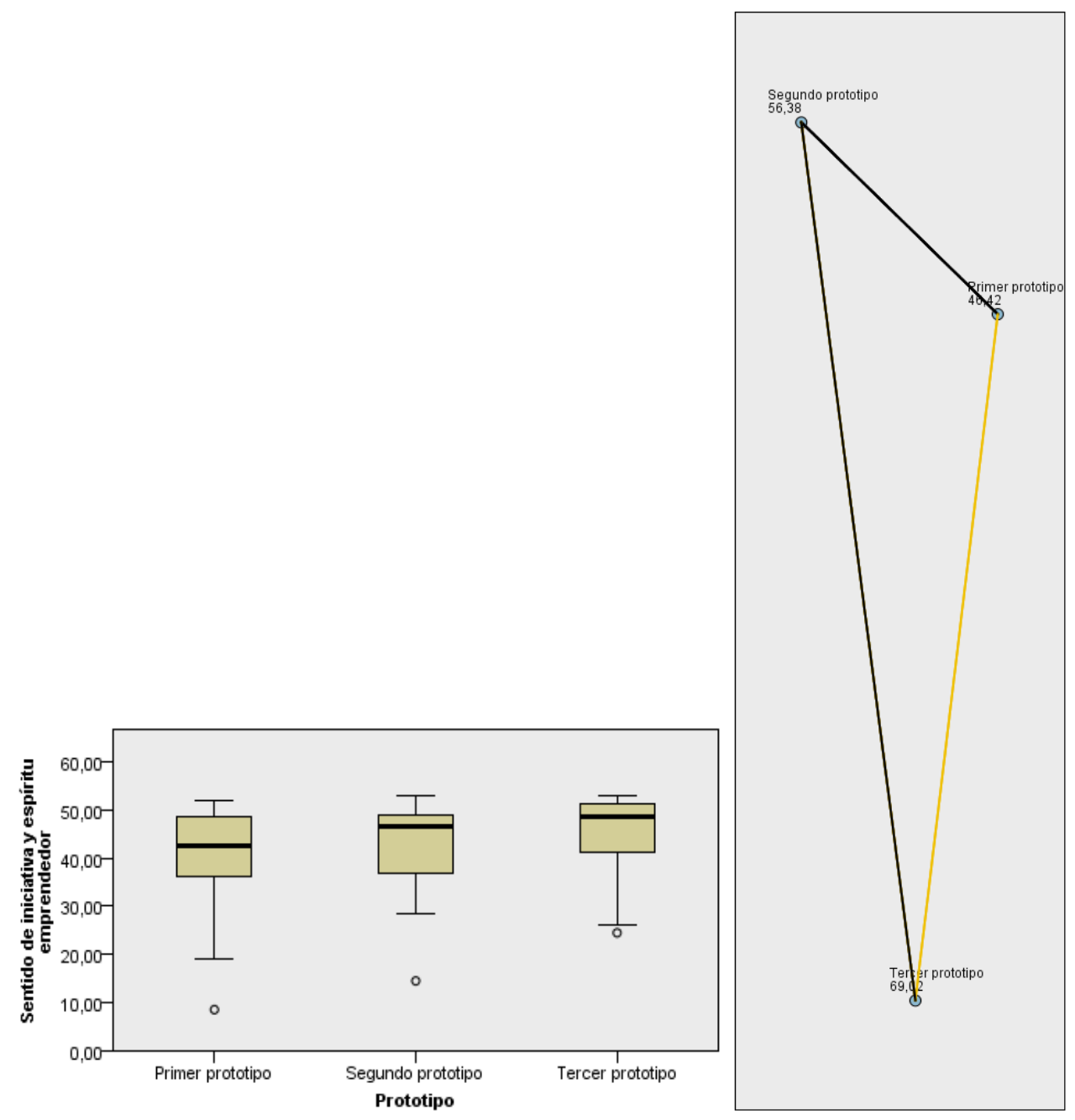

Figura 7.4. Diagrama de cajas y bigotes y gráfico de nodos correspondientes al caso del SIE. 


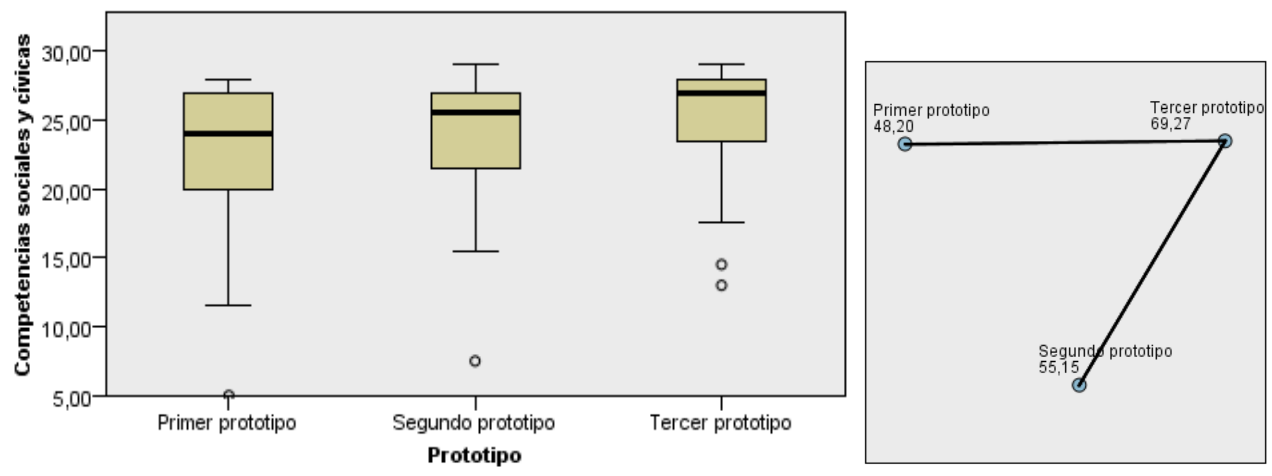

Figura 7.5. Diagrama de cajas y bigotes y gráfico de nodos correspondientes al caso de la CSC.

Sin embargo, no existieron diferencias significativas derivadas de la variable prototipo, en cambio, en los casos de la CMCT, la CPAA y las CEC. En las Figuras 7.6, 7.7 y 7.8 se presentan los diagramas de cajas y bigotes correspondientes a estos tres casos.

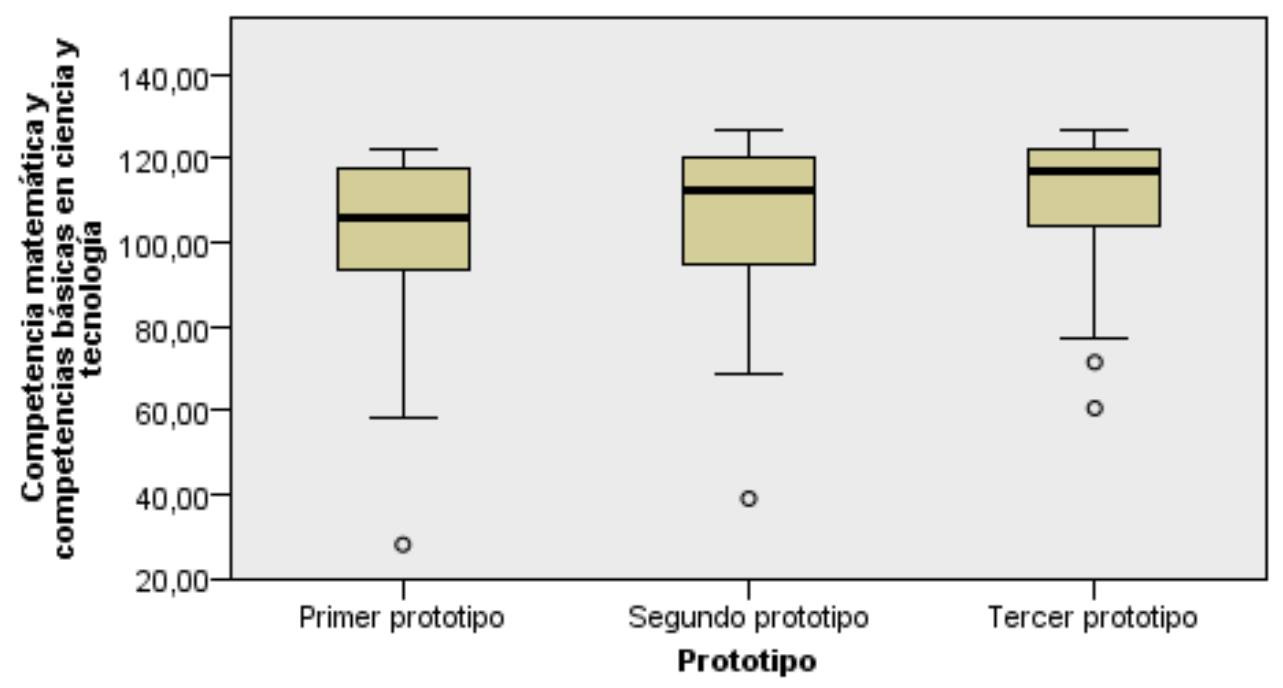

Figura 7.6. Diagrama de cajas y bigotes correspondiente al caso de la CMCT. 


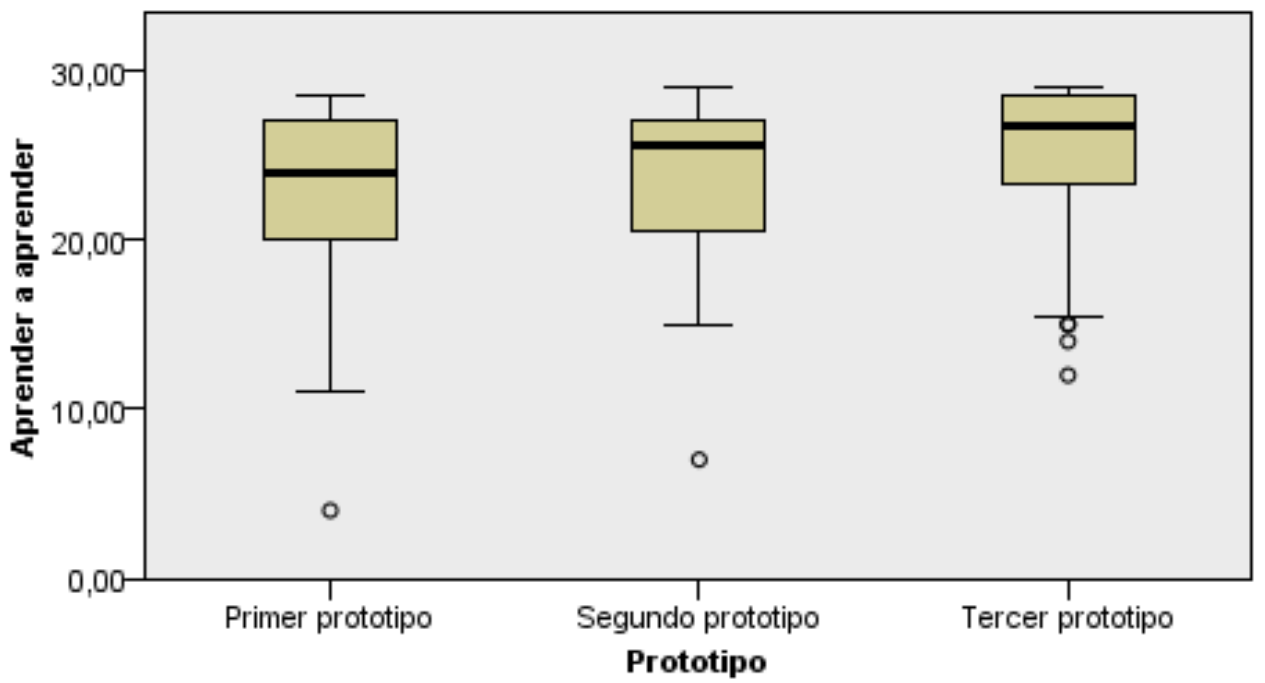

Figura 7.7. Diagrama de cajas y bigotes correspondiente al caso de la CPAA.

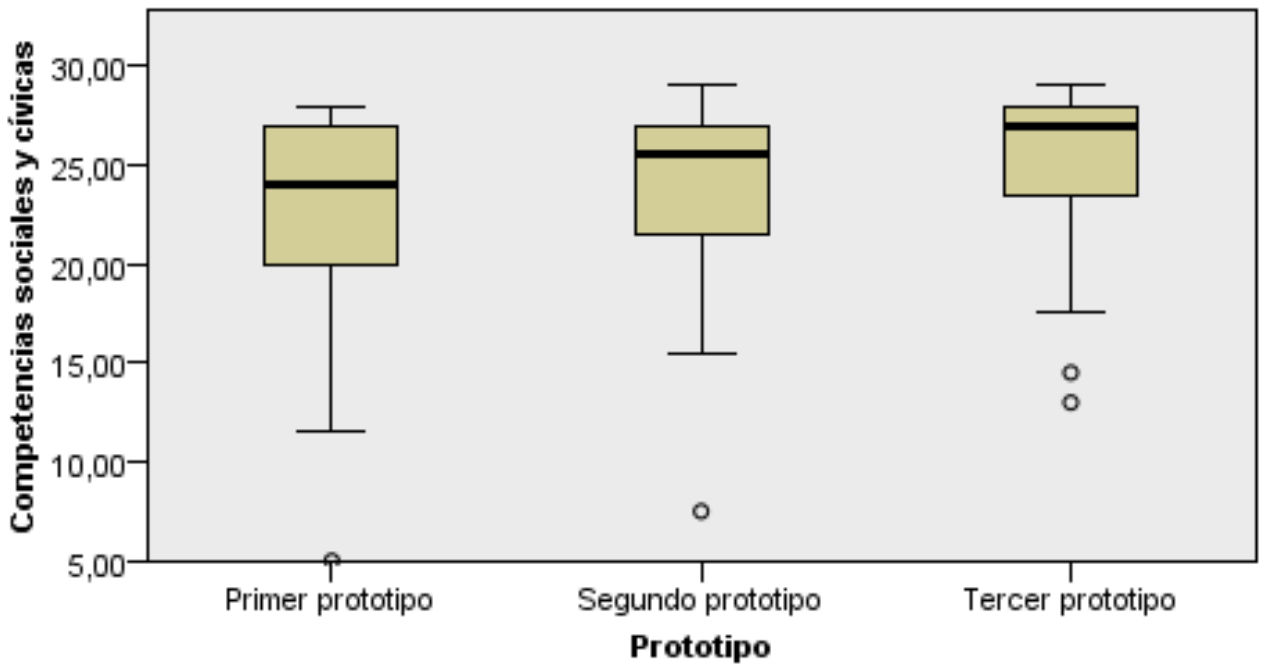

Figura 7.8. Diagrama de cajas y bigotes correspondiente al caso de las CSC.

Controlando la variable grupo, la prueba $\mathrm{H}$ de Kruskal-Wallis reveló la existencia de diferencias significativas solamente en la CD. Este resultado implica que no existen diferencias en el nivel competencial general alcanzado por el alumnado en esta UD y, en particular, en la CMCT, debidas a los 
diferentes maestros que implementaron la UD, a pesar de sus diferencias personales. Al respecto, hay que tener en cuenta las características particulares de esta implementación - corta duración y altamente motivadora, por ser diferente, para maestros y alumnado- que podrían explicar parte de esta independencia de resultados en relación con los estilos didácticos de los maestros. En la Tabla 7.20 se muestran los resultados de esta prueba.

Tabla 7.20. Prueba H de Kruskal-Wallis controlando la variable grupo en el total de la muestra

\begin{tabular}{lcrrrrrrr}
\hline \hline & CG & CCL & CMCT & CD & CPAA & SIE & CEC & CSC \\
\hline H de Kruskal- & 8,476 & 8,988 & 6,749 & 14,331 & 6,400 & 8,430 & 7,049 & 7,890 \\
Wallis & & & & & & & & \\
gl & 5 & 5 & 5 & 5 & 5 & 5 & 5 & 5 \\
Sig. asintótica &, 132 &, 110 &, 240 &, 014 &, 269 &, 134 &, 217 &, 162 \\
\hline \hline
\end{tabular}

a. Prueba de Kruskal Wallis

b. Variable de agrupación: Grupo

Las pruebas post hoc determinaron que estas diferencias significativas se encontraban entre el Grupo 1 y el Grupo 6 a favor del último $(p=.008)$. En la Figura 7.9 se presentan el diagrama de cajas y bigotes y el gráfico de nodos correspondientes a este caso. 

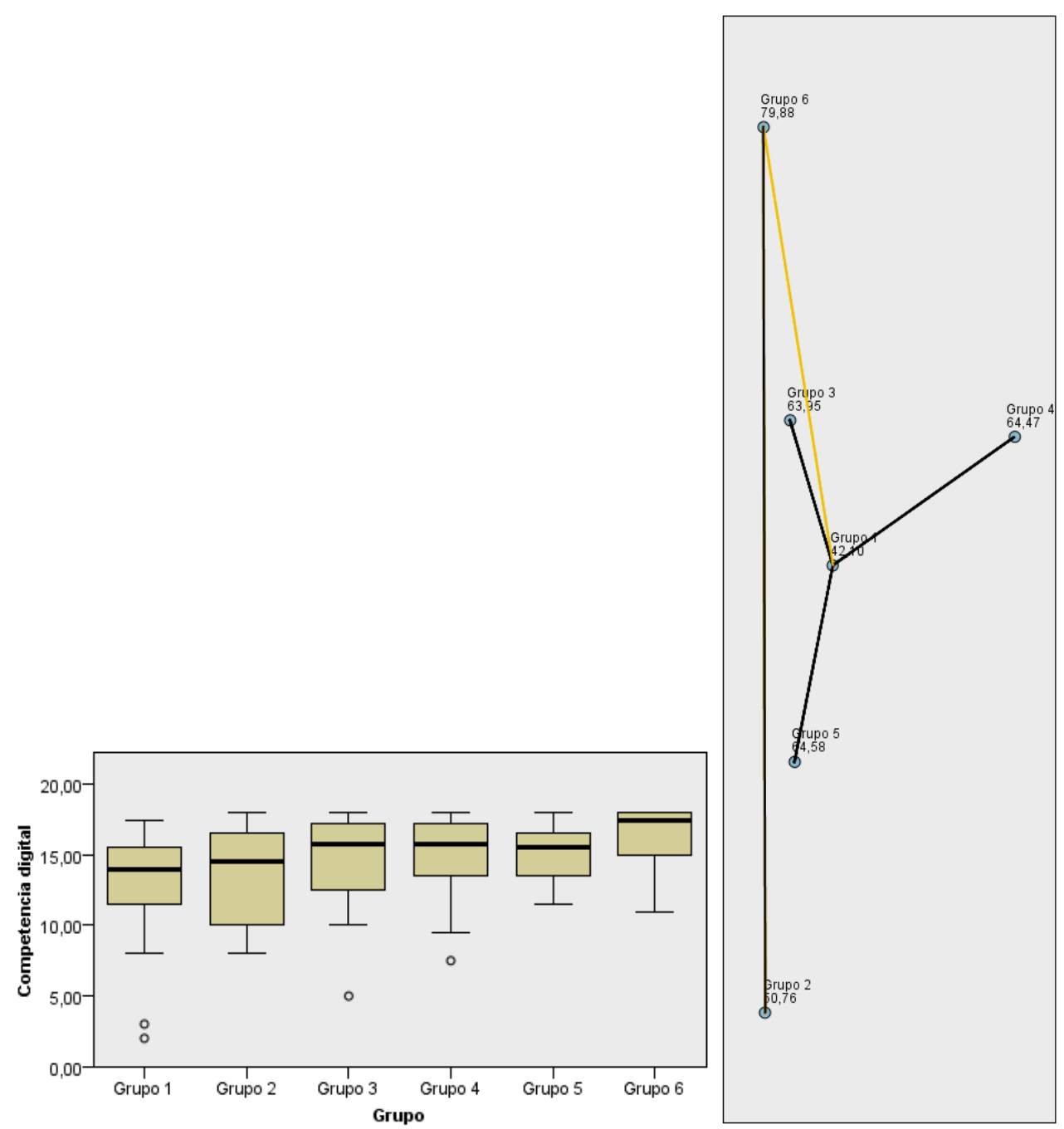

Figura 7.9. Diagrama de cajas y bigotes y gráfico de nodos correspondientes al caso de la CD.

7.4.2.2. Resultados de la evaluación de actitudes hacia la ciencia e intenciones hacia la ciencia, la ingeniería y su conjunto

En cuanto al análisis del plano actitudinal del total de la muestra, en la Tabla 7.21 se muestran los estadísticos descriptivos correspondientes a los cuatro constructos analizados correspondientes con las actitudes hacia la ciencia y las 
intenciones hacia la ciencia y la ingeniería, así como las intenciones hacia el conjunto de ellas.

Tabla 7.21. Estadísticos descriptivos de las actividades e intenciones en el total de la muestra

\begin{tabular}{lrrrr}
\hline \hline & Actitudes ciencia & Intención ciencia & Intención ingeniería & Intención STEM \\
\hline $\mathrm{N}$ & 117 & 117 & 117 & 117 \\
$M$ & 4,165 & 3,169 & 3,023 & 3,121 \\
$D E$ &, 652 &, 840 &, 822 &, 706 \\
\hline \hline
\end{tabular}

Como se ha indicado anteriormente, los valores son todos positivos, siendo particularmente altos para las actitudes hacia la ciencia.

Además, en este último análisis del plano actitudinal con el total de la muestra se consideró adecuado indagar en torno a las variables de género y prototipo cuyos resultados se exponen a continuación.

Controlando la variable género, la prueba U de Mann-Whitney reveló la existencia de diferencias significativas solamente en el constructo de Intención hacia la ingeniería. En la Tabla 7.22 se muestran los resultados de esta prueba.

Tabla 7.22. Prueba U de Mann-Whitney controlando la variable género en el total de la muestra

\begin{tabular}{lrrrr}
\hline \hline & $\begin{array}{c}\text { Actitudes } \\
\text { ciencia }\end{array}$ & \multicolumn{1}{c}{$\begin{array}{c}\text { Intención } \\
\text { ciencia }\end{array}$} & $\begin{array}{c}\text { Intención } \\
\text { ingeniería }\end{array}$ & \multicolumn{1}{c}{$\begin{array}{c}\text { Intención } \\
\text { STEM }\end{array}$} \\
\hline U de Mann-Whitney & 1608,000 & 1584,500 & 1212,000 & 1408,500 \\
$\mathrm{Z}$ &,- 452 &,- 583 & $-2,672$ & $-1,548$ \\
Sig. &, 651 &, 560 &, 008 &, 122 \\
asintótica(bilateral) & & & & \\
\hline \hline
\end{tabular}

a. Variable de agrupación: Género

En la Tabla 7.23 se muestran los estadísticos descriptivos que evidencian que las diferencias significativas en el constructo Intención ingeniería fueron a favor de los chicos. Además, se comprueba que los valores 
del resto de constructos son prácticamente idénticos, de hecho, existe una coincidencia en las medianas de dos de ellos.

Tabla 7.23. Estadísticos descriptivos de la evaluación de los cuatro constructos por género en el total de la muestra

\begin{tabular}{|c|c|c|c|c|c|}
\hline \multicolumn{2}{|c|}{ Género } & $\begin{array}{l}\text { Actitudes } \\
\text { ciencia }\end{array}$ & $\begin{array}{l}\text { Intención } \\
\text { ciencia }\end{array}$ & $\begin{array}{l}\text { Intención } \\
\text { ingeniería }\end{array}$ & $\begin{array}{l}\text { Intención } \\
\text { STEM }\end{array}$ \\
\hline \multirow[t]{4}{*}{ Chico } & $\mathrm{N}$ & 65 & 65 & 65 & 65 \\
\hline & Me & 4,333 & 3,000 & 3,000 & 3,111 \\
\hline & $D E$ & 677 &, 784 & ,837 & 638 \\
\hline & $M$ & 4,177 & 3,203 & 3,190 & 3,198 \\
\hline \multirow[t]{4}{*}{ Chica } & $\mathrm{N}$ & 52 & 52 & 52 & 52 \\
\hline & $M e$ & 4,333 & 3,000 & 3,000 & 3,000 \\
\hline & $D E$ & ,626 & ,913 &, 759 &, 778 \\
\hline & $M$ & 4,151 & 3,128 & 2,814 & 3,023 \\
\hline
\end{tabular}

Es interesante destacar este resultado. La literatura en general, y si se toma el Informe PISA 2015 en particular, revela actitudes e intenciones hacia la ciencia menores y estadísticamente significativas en las chicas respecto de los chicos. Esto no parece suceder después de aplicar esta UD. Por otra parte, y aunque la intención hacia la ingeniería es un constructo que se encuentra aún en proceso de validación, la tendencia obtenida parece ser coherente con los resultados que reportó el Informe PISA 2015, indicando que prácticamente en todos los países, los chicos aspiran a ser informáticos, científicos o ingenieros más a menudo que las chicas.

Controlando la variable prototipo, la prueba $\mathrm{H}$ de Kruskal-Wallis reveló la existencia de diferencias significativas en el constructo de Actitudes hacia la ciencia. En la Tabla 7.24 se muestran los resultados de esta prueba. 
Tabla 7.24. Prueba H de Kruskal-Wallis controlando la variable prototipo en el total de la muestra

\begin{tabular}{lrrrr}
\hline \hline & $\begin{array}{c}\text { Actitudes } \\
\text { ciencia }\end{array}$ & \multicolumn{1}{c}{$\begin{array}{c}\text { Intención } \\
\text { ciencia }\end{array}$} & $\begin{array}{l}\text { Intención } \\
\text { ingeniería }\end{array}$ & $\begin{array}{c}\text { Intención } \\
\text { STEM }\end{array}$ \\
\hline H de Kruskal- & 8,137 & 1,750 & 1,003 &, 343 \\
Wallis & 2 & & & \\
gl &, 017 &, 417 &, 606 &, 843 \\
Sig. asintótica & & & 2 & 2 \\
\hline \hline
\end{tabular}

a. Prueba de Kruskal Wallis

b. Variable de agrupación: Prototipo

Las pruebas post hoc determinaron que estas diferencias significativas se encontraban entre el Prototipo1 y el Prototipo 2 a favor del último $(p=$ .013). En la Figura 7.10 se presentan el diagrama de cajas y bigotes y el gráfico de nodos correspondientes a ese caso.
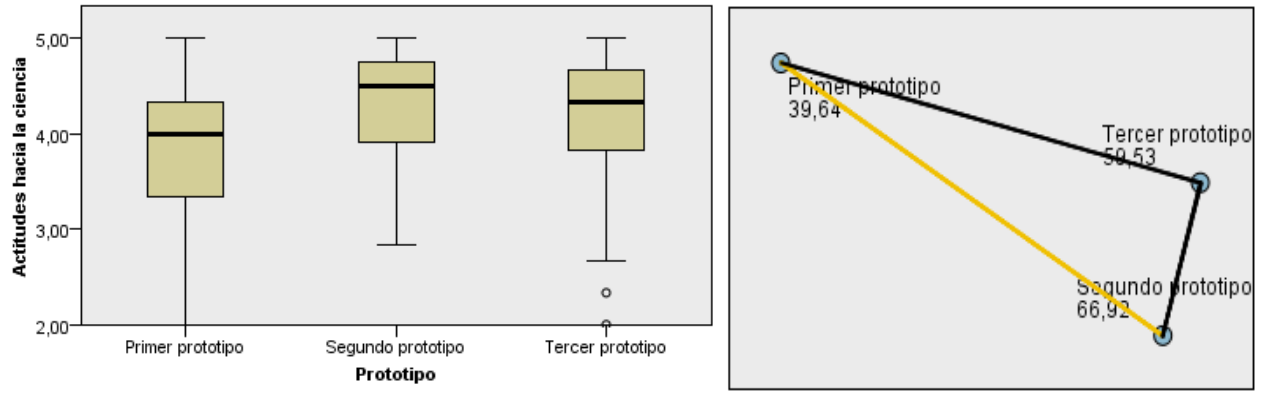

Figura 7.10. Diagrama de cajas y bigotes y gráfico de nodos correspondientes al caso del constructo de Actitudes hacia la ciencia.

No existieron diferencias significativas derivadas de la variable prototipo, en cambio, en los casos del constructo de Intención hacia la ciencia, Intención hacia la ingeniería e Intención hacia STEM. En las Figuras 7.11, 7.12 y 7.13 se presentan los diagramas de cajas y bigotes correspondientes a estos tres casos. 


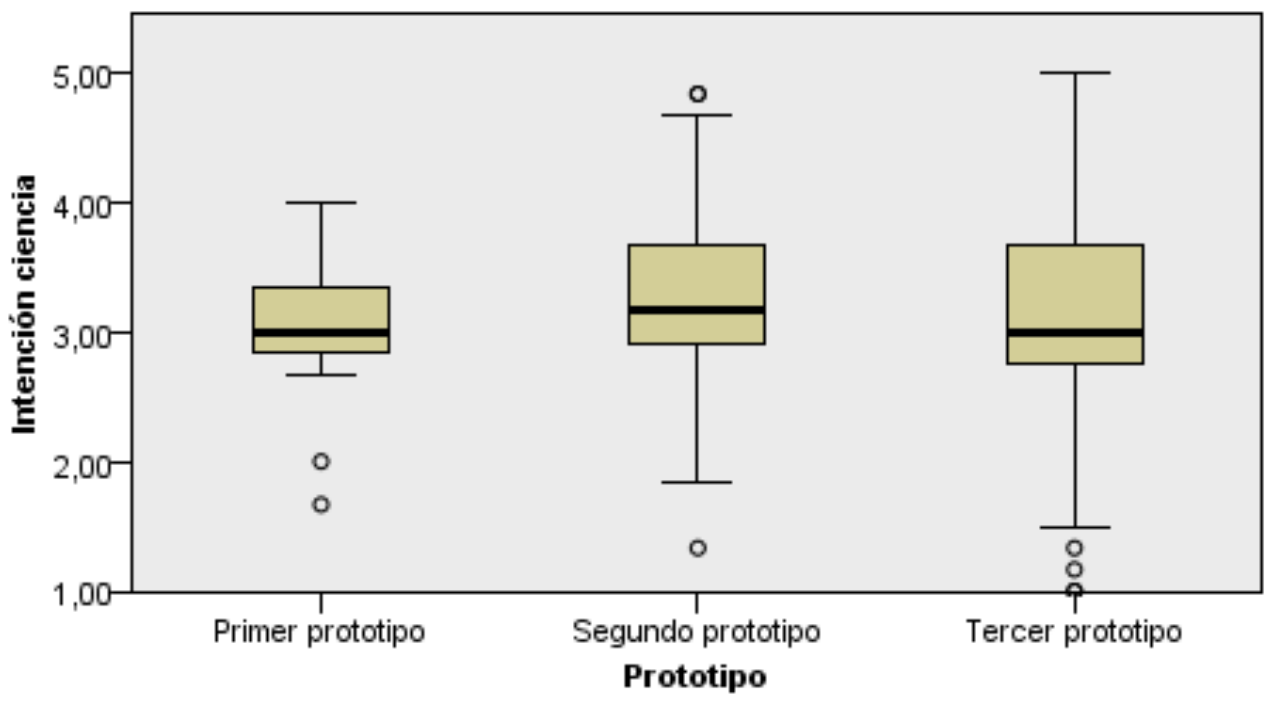

Figura 7.11. Diagrama de cajas y bigotes correspondiente al caso del constructo de Intención hacia la ciencia.

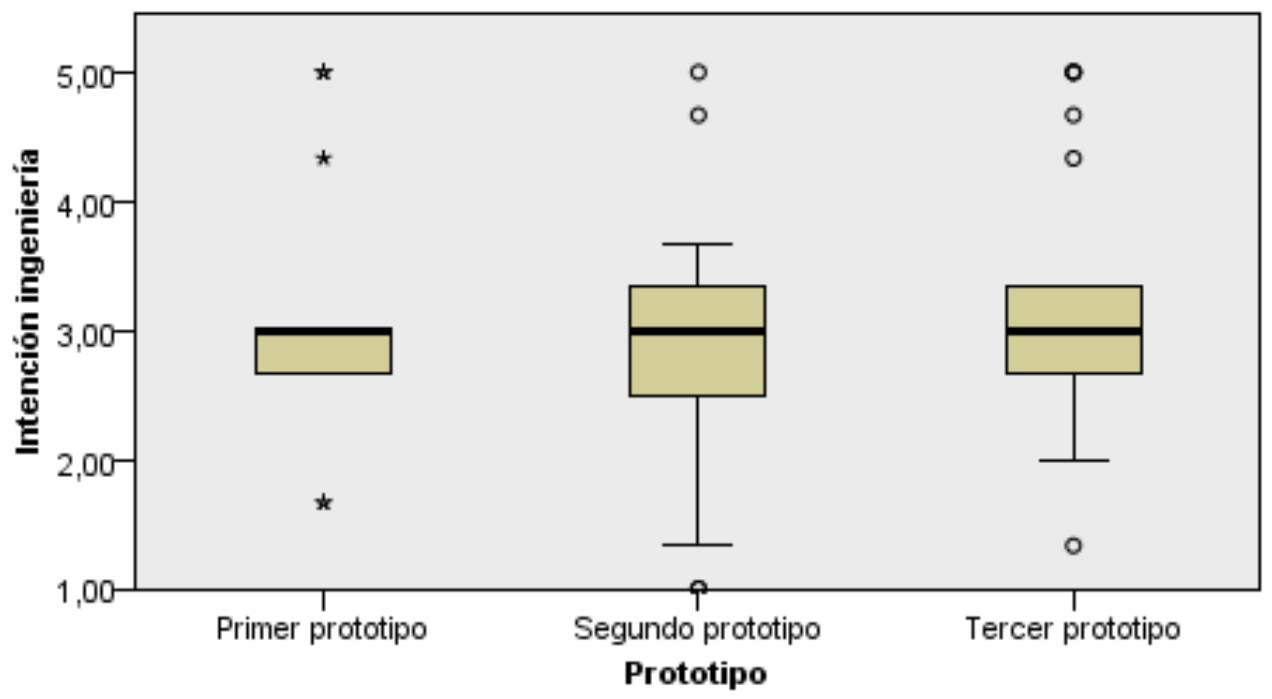

Figura 7.12. Diagrama de cajas y bigotes correspondiente al caso del constructo de Intención hacia la ingeniería. 


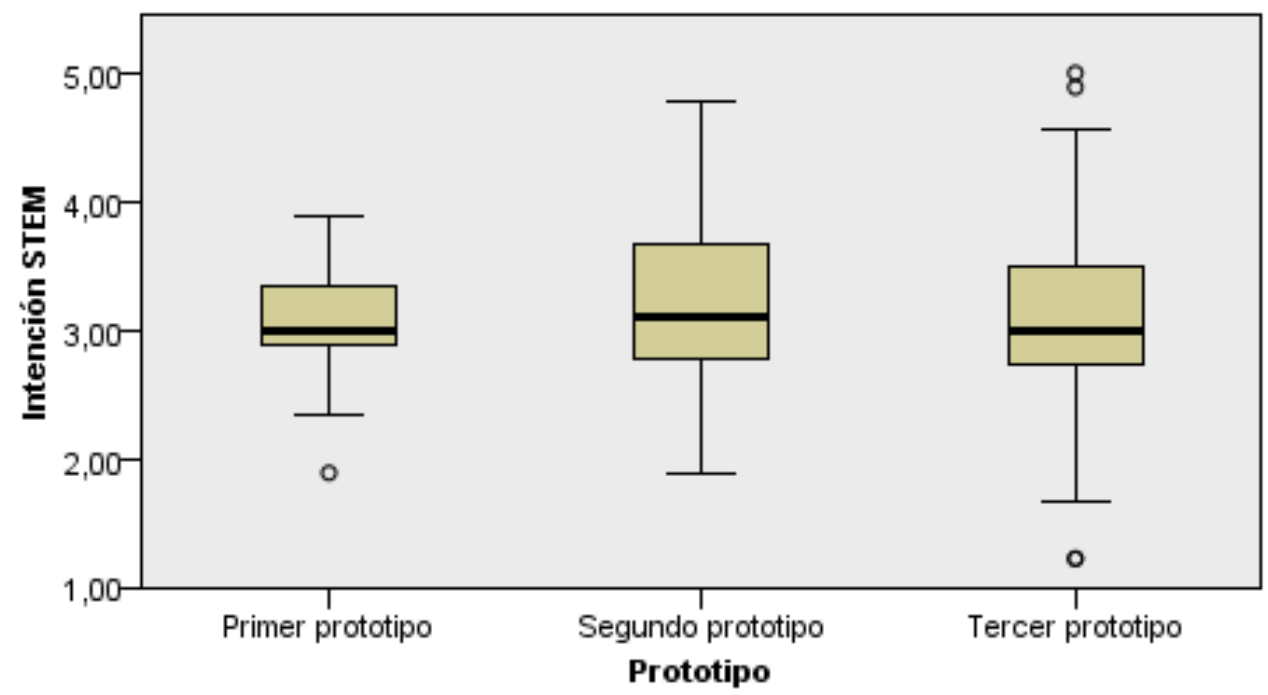

Figura 7.13. Diagrama de cajas y bigotes correspondiente al caso del constructo de Intención hacia STEM.

\subsubsection{Comparación de los resultados de la evaluación de actitudes} hacia la ciencia e intenciones hacia la ciencia, la ingeniería y su conjunto entre quinto y sexto curso

Como se comentó, se quiso evaluar si existían diferencias en los cuatro constructos derivadas de la implementación de la UD STEAM empleando un estudio de cohortes con una muestra de quinto curso. Así, controlando la variable curso, la prueba U de Mann-Whitney reveló la existencia de diferencias significativas en el constructo de Actitudes hacia la ciencia. No se detectaron diferencias significativas derivadas del curso en el resto de los constructos. En la Tabla 7.25 se muestran los resultados de esta prueba. 
Tabla 7.25. Prueba U de Mann Whitney controlando la variable curso

\begin{tabular}{lrrrr}
\hline \hline & $\begin{array}{c}\text { Actitudes } \\
\text { ciencia }\end{array}$ & \multicolumn{1}{c}{$\begin{array}{c}\text { Intención } \\
\text { ciencia }\end{array}$} & $\begin{array}{c}\text { Intención } \\
\text { ingeniería }\end{array}$ & \multicolumn{1}{c}{$\begin{array}{c}\text { Intención } \\
\text { STEM }\end{array}$} \\
\hline U de Mann-Whitney & 5899,000 & 7498,500 & 7165,500 & 7313,500 \\
W de Wilcoxon & 15352,000 & 16951,500 & 16618,500 & 16766,500 \\
Z & $-3,636$ &,- 888 & $-1,493$ & $-1,204$ \\
Sig. &, 000 &, 375 &, 136 &, 229 \\
asintótica(bilateral) & & & & \\
\hline \hline
\end{tabular}

a. Variable de agrupación: Curso

En la Tabla 7.26 se muestran los estadísticos descriptivos que evidencian que estas diferencias significativas fueron a favor del alumnado de sexto curso.

Tabla 7.26. Estadísticos descriptivos de la evaluación de actitudes hacia la ciencia por cursos

\begin{tabular}{llr}
\hline \hline Curso & & Actitudes ciencia \\
\hline 5 & $\mathrm{n}$ & 137 \\
& $M e$ & 4,0000 \\
& $D E$ &, 80912 \\
& $M$ & 3,8212 \\
\hline 6 & $\mathrm{n}$ & 117 \\
& $M e$ & 4,3333 \\
& $D E$ &, 65232 \\
& $M$ & 4,1652 \\
\hline \hline
\end{tabular}

Sin embargo, acudiendo a la tabla de rangos (Tabla 7.27) de esta misma prueba, se puede comprobar que, aunque no significativas, también hubo diferencias en el resto de los constructos a favor del sexto curso. 
Tabla 7.27. Tabla de rangos de la prueba U de Mann-Whitney controlando la variable curso

\begin{tabular}{llll}
\hline & Curso & N & Rango promedio \\
\hline Actitudes ciencia & 5 & 137 & 112,06 \\
& 6 & 117 & 145,58 \\
& Total & 254 & 123,73 \\
\hline Intención ciencia & 5 & 137 & 131,91 \\
& 6 & 117 & 121,30 \\
\hline Intención ingeniería & Total & 254 & 134,76 \\
& 5 & 137 & 122,38 \\
& 6 & 117 & 133,49 \\
\hline Intención STEM & Total & 254 & \\
\hline \hline
\end{tabular}

Por ello, como último complemento de esta significación estadística, se quiso analizar el tamaño del efecto para poder comprender con mayor profundidad las diferencias entre estos dos grupos. A través de la $r$ de Rosenthal se obtuvieron los siguientes valores:

- Actitudes ciencia: $r=0.228$

- Intención ciencia: $r=0.055$

- Intención ingeniería: $\mathrm{r}=0.093$

- Intención STEM: $\mathrm{r}=0.075$

Estos resultados ponen de manifiesto la presencia de un tamaño de efecto en todos los constructos, que se asocia a la implementación de la UD STEAM, dado que el alumnado de sexto no realizó ninguna otra actividad diferente de las características de una metodología tradicional relacionada con la ciencia que las de la UD. Este efecto es pequeño en los constructos Intención ciencia, Intención ingeniería e Intención STEM, así como en el de Actitudes ciencia, si bien este último presenta un valor muy superior comparado con los anteriores constructos, acercándose a presentar un tamaño de efecto medio 0.30 - Estos resultados se muestran congruentes con la significación obtenida en la prueba U de Mann-Whitney. También son coherentes con el modelo teórico TRAPB (Summers y Abd-El-Khalick, 2018), que sustentó el desarrollo del instrumento BRAINS, dado que en él se asume que las actitudes 
representan uno de los componentes que determinan las intenciones siendo, por lo tanto, estas últimas más complejas de cambiar dado que en su desarrollo intervienen otros factores.

\subsubsection{Resultados del análisis mixto}

Para poder alcanzar una comprensión holística de la relación entre el desarrollo competencial escolar-concretamente de la CMCT- y las Actitudes hacia la ciencia e intenciones hacia la ciencia, la ingeniería y su conjunto en el marco de la implementación de la UD STEAM, algunos resultados procedentes del análisis cuantitativo y cuantitativo fueron fusionados y comparados.

Recordar que la concepción del constructo competencial aquí adoptada incluye la dimensión de las actitudes, por lo que se esperaba la existencia de algún tipo de relación entre la tendencia del desarrollo competencial escolar en este caso de la CMCT - y la de los constructos analizados.

Para ello, primeramente, se representa de manera gráfica, a través de barras de error, la $M$ y la $D E$ de la CMCT (Figura 7.14) y de cada uno de los cuatro constructos (Figuras 7.15, 7.16, 7.17 y 7.18) a lo largo de los tres prototipos y considerándose el total de la muestra. 


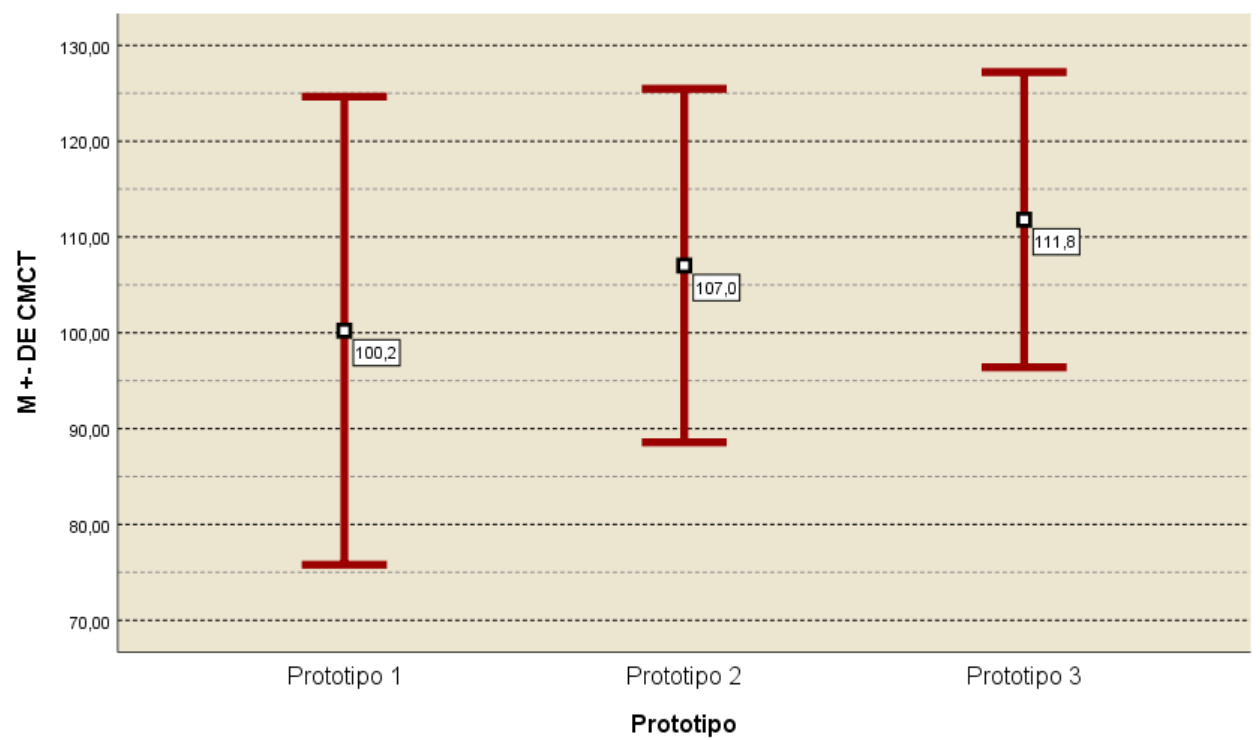

Figura 7.14. Barras de error con $M$ y DE de la Intención hacia la ciencia a lo largo de los tres prototipos.

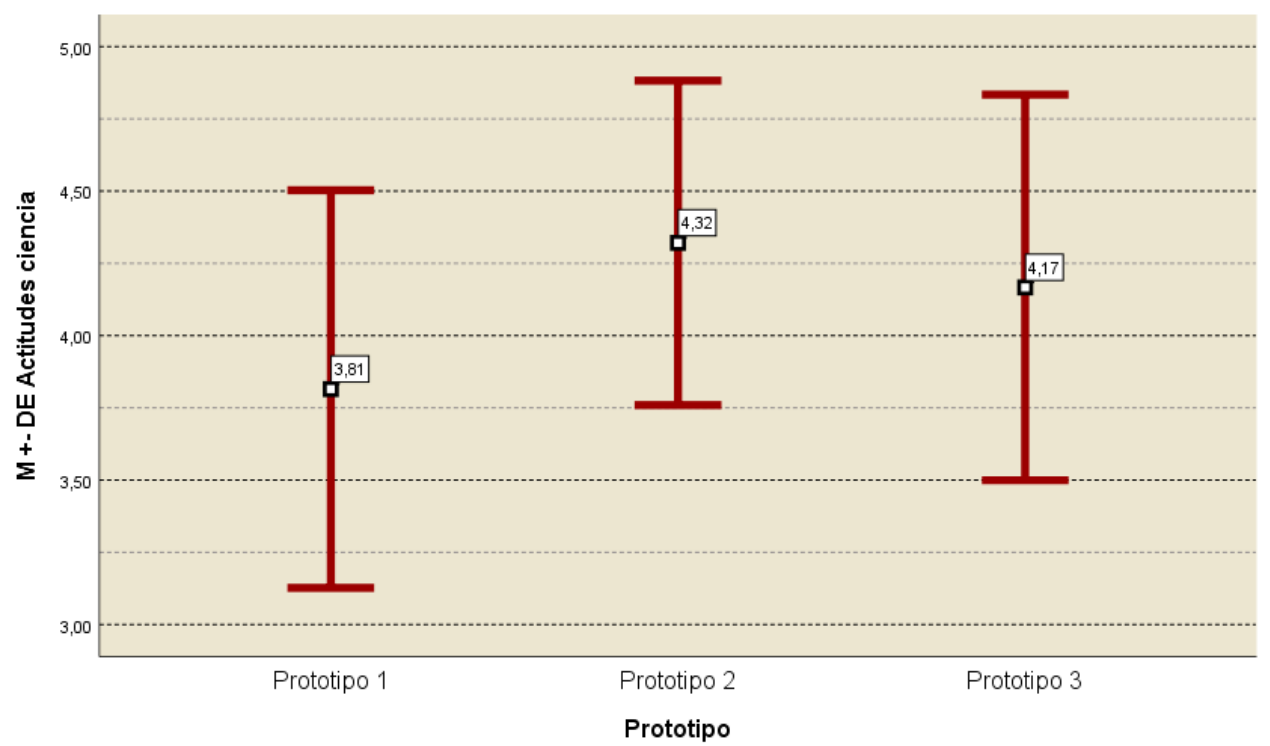

Figura 7.15. Barras de error con $M$ y $D E$ de las Actitudes hacia la ciencia a lo largo de los tres prototipos. 


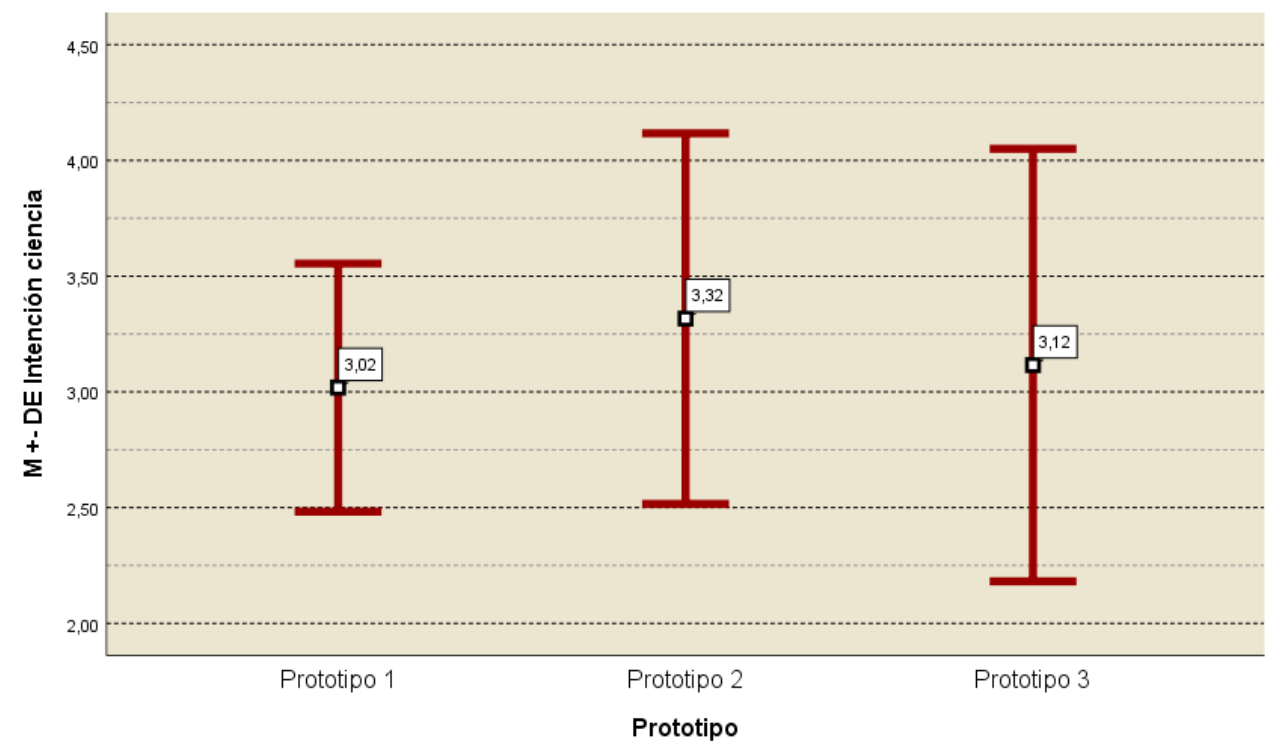

Figura 7.16. Barras de error con $M$ y $D E$ de la Intención hacia la ciencia a lo largo de los tres prototipos.

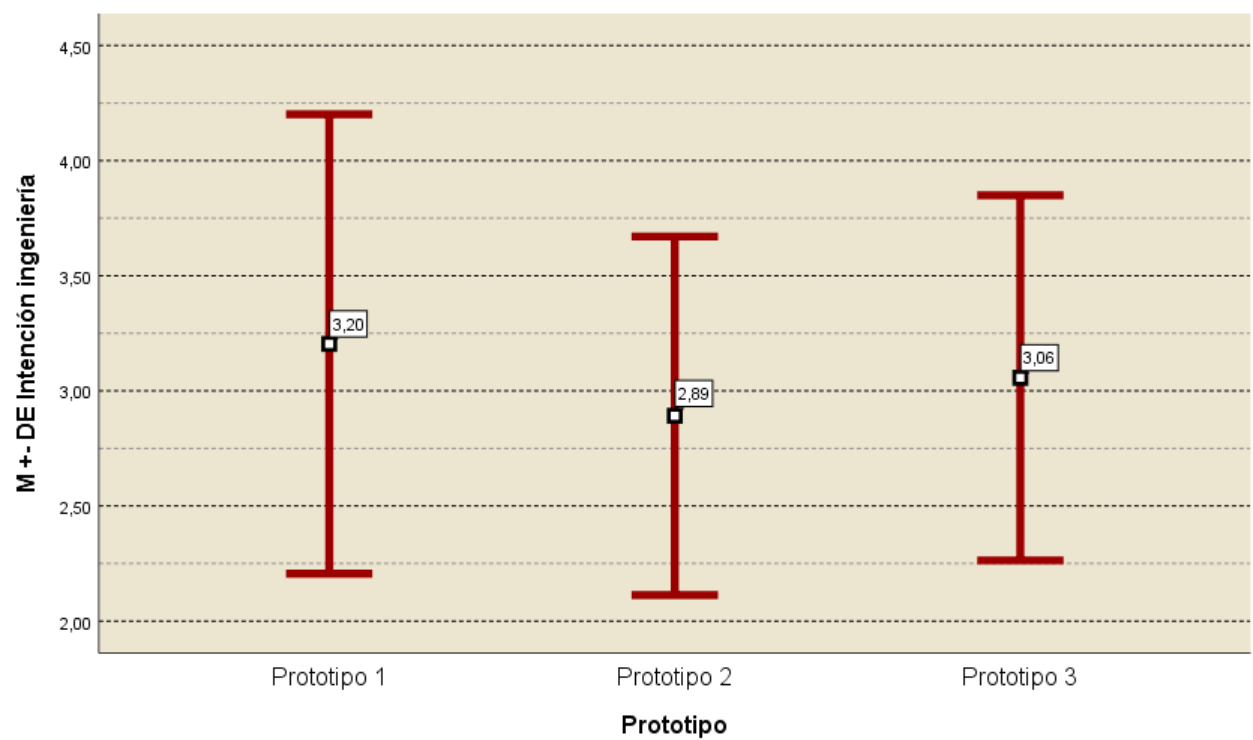

Figura 7.17. Barras de error con $M$ y $D E$ de la Intención hacia la ingeniería a lo largo de los tres prototipos. 


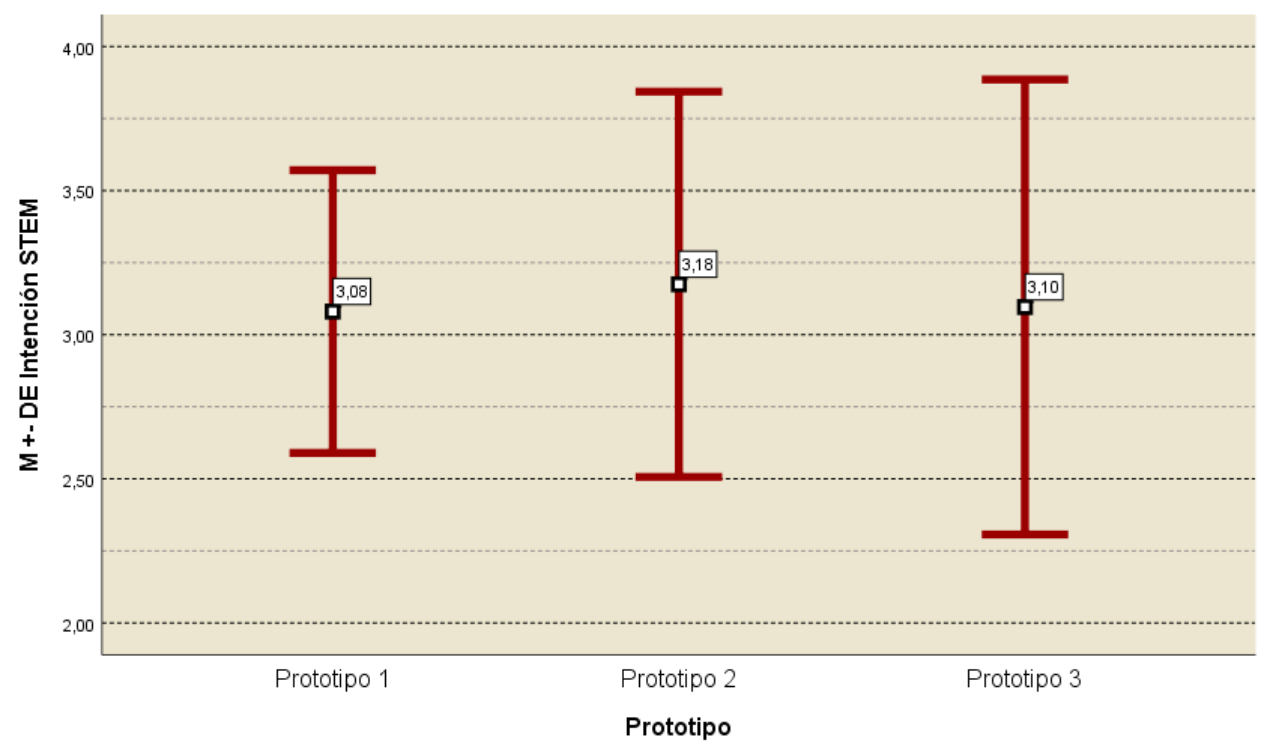

Figura 7.18. Barras de error con $M$ y DE de la Intención hacia STEM a lo largo de los tres prototipos.

Una vez conocidos estos datos, se presenta una fusión de estos a través de un gráfico de líneas que representa la $M$ de la CMCT — transformada a una escala de cinco valores- y de los cuatro constructos a lo largo de los tres prototipos (Figura 7.19). 


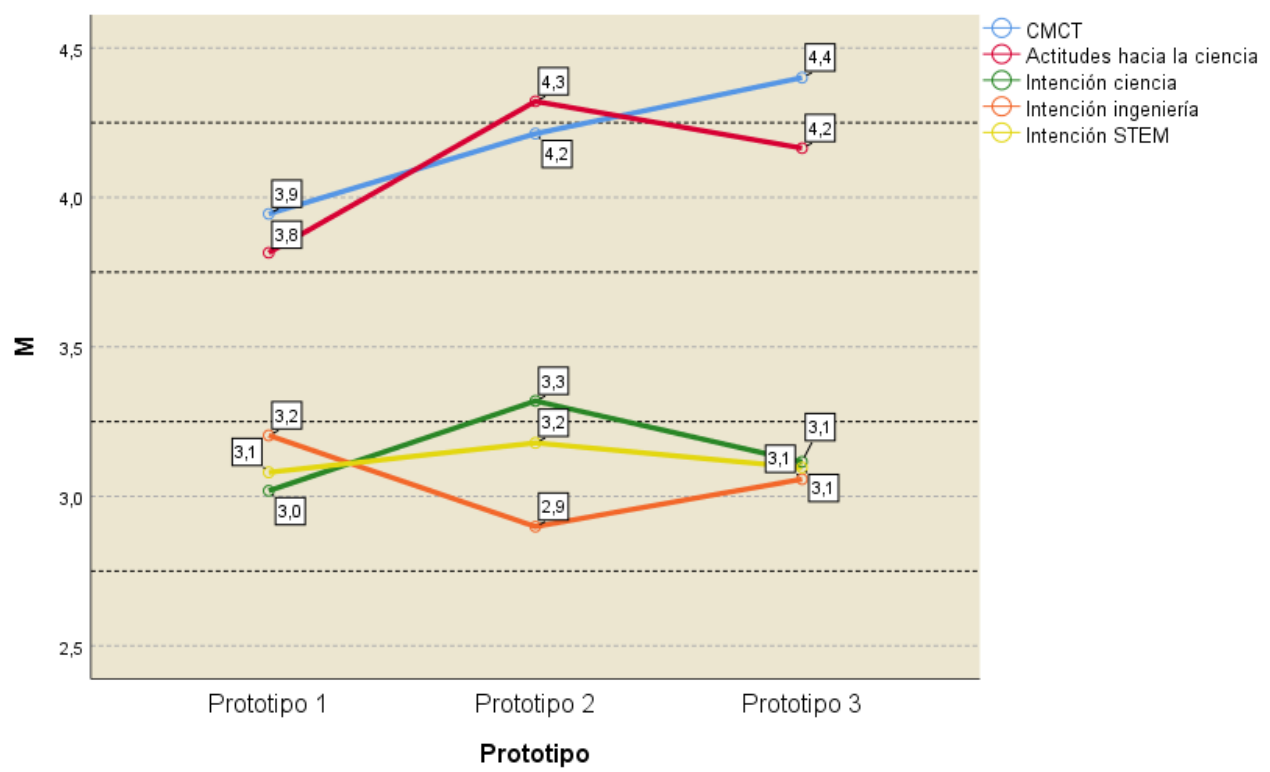

Figura 7.19. Gráfico de líneas con $M$ de la CMCT y de los cuatro constructos a lo largo de los tres prototipos.

En un ejercicio de comparación de esta fusión de datos, se puede observar una relación positiva entre el desarrollo de la CMCT y el de las Actitudes hacia la ciencia, relación que no aparece tan claramente en el caso de los otros tres constructos analizados. Este último resultado es coherente con lo expuesto en la subsección 7.4.2.3, sobre la mayor dificultad de conseguir modificaciones en las intenciones que en las actitudes.

\subsection{Discusión de los resultados}

A lo largo de esta sección se discuten, de manera secuenciada, las cuestiones relacionadas con las tres agrupaciones de resultados empíricos focalizados en esta tesis doctoral: la evaluación del desarrollo competencial escolar; la evaluación de las actitudes hacia la ciencia y las intenciones hacia la ciencia, la ingeniería y su conjunto; y las mejoras para el conjunto de los prototipos de la UD.

En cuanto a la evaluación del desarrollo competencial escolar, como ya se comentó al inicio de esta tesis doctoral, no existe apenas literatura que evalúe 
específicamente el nivel competencial alcanzado por alumnado de Educación Primaria tras la implementación de propuestas STEAM integradas. Por ello, aunque más adelante se tratará de establecer comparaciones entre los resultados aquí obtenidos y los derivados de los estudios que más cercanos hemos encontrado a esta temática, se ha considerado adecuado, dada su semejanza, realizar un primer ejercicio de discusión tomando como referencia los resultados de la Evaluación fin de etapa de $6^{\circ}$ de Educación Primaria 20172018 de la comunidad de Castilla y León (CyL).

Así, atendiendo a la media de los resultados de los estudiantes de CyL en la Evaluación fin de etapa $6^{\circ}$ de Primaria 2017-2018 (JCyL, 2018), se puede observar que estos se ubican en el nivel tres de los seis niveles de rendimiento establecidos para las tres pruebas cognitivas que se realizan en este marco: Competencia matemática, Competencias básicas en ciencia y Tecnología y CCL. Si se extrapolan los resultados en las respectivas variables - es decir, lo que aquí se evaluó como CMCT y CCL- del alumnado después de la intervención con la UD a este rango de niveles, este se encontraría en las tres variables en el nivel más alto, es decir, seis de seis. Por tanto, el nivel de desarrollo competencial escolar alcanzado en esta UD por el alumnado de esta investigación sobrepasa notablemente el evaluado en el alumnado de la misma edad y comunidad autónoma en la Evaluación fin de etapa.

En cuestión de género y, tomando los mismos resultados de esta Evaluación fin de etapa, cabe destacar que, el rendimiento de las chicas tanto en la Competencia Matemática como en las Competencias básicas en ciencia y tecnología se sitúa, aunque de manera no significativa, por debajo del de los chicos, resultados que no coinciden con los aquí obtenidos, donde las chicas alcanzan en la CMCT un mayor y significativo desempeño. Sí coinciden, en cambio, los resultados en cuanto al rendimiento en la CCL, siendo las chicas estadísticamente superiores a los chicos tanto en la Evaluación fin de etapa como en esta investigación.

Por otra parte, se ha considerado relevante establecer una breve comparación tomando ahora los resultados de la evaluación competencial reportados por el Informe PISA 2015 (OECD, 2016). Si bien esta evaluación estandarizada se centra en el alumnado de 15 años, los resultados aquí reportados ofrecen cierta información de la evolución de un sistema educativo. 
Atendiendo de este modo a la media de los resultados de los estudiantes tanto de España como de CyL reportados por este Informe, se puede observar que estos se ubican en el nivel cuatro de los siete niveles que se establecen en cuanto a lo que denominan la competencia de ciencias. Asimismo, estos estudiantes se encuentran en el nivel tres de los seis establecidos para la competencia de matemáticas. En cambio, extrapolando los resultados en la respectiva variable —es decir, lo que aquí se evaluó como CMCT- del alumnado participante en esta investigación a cada uno de estos rangos de niveles, este se encontraría en las dos variables en el nivel seis de siete o seis de seis. De nuevo, la media del nivel de desarrollo competencial escolar aquí alcanzado se sitúa bastante por encima que la evaluada en el Informe internacional.

En cuestión de género, siguiendo con los resultados de este Informe, cabe destacar que las chicas se sitúan significativamente por debajo de los chicos en cuanto a su rendimiento en ciencias y en matemáticas, resultados que no coinciden con los aquí obtenidos, donde las chicas alcanzan en la CMCT un desempeño alto y significativamente mayor que el de los chicos.

Si se continúa tomando la media de los resultados, esta vez de los relacionados con la denominada competencia lectora, de los estudiantes tanto de España como de CyL reportados por el mismo Informe, se puede observar que estos se ubican en el nivel cuatro de los siete existentes. Sin embargo, al extrapolar nuevamente los resultados en la respectiva variable - en este caso de la competencia más parecida aquí evaluada, la CCL— del alumnado de esta investigación a este rango de niveles, este se encontraría en el nivel seis de siete en la variable evaluada por el Informe. De nuevo, el nivel competencial escolar desarrollado por el alumnado de esta investigación sobrepasa holgadamente el evaluado por el Informe internacional.

En cuestión de género, los resultados del mismo Informe muestran que las chicas se sitúan significativamente por encima de los chicos en cuanto a su rendimiento en la CCL, resultados que coinciden con los aquí obtenidos.

Es relevante discutir los resultados obtenidos en relación con la CMCT según género, que parecen acordar con la literatura existente sobre el tema. Según el informe de la UNESCO (2017), que reunió toda la evidencia científica disponible relacionada con la brecha de género en las áreas STEM, propuestas que tengan en cuenta los intereses de las chicas, por ejemplo, vinculando 
conceptos abstractos con situaciones de la vida real, pueden ayudar a aumentar su interés en STEM. Así, es probable que el planteamiento de la UD STEAM integrada, propiciando la enseñanza de los contenidos de ciencias, matemáticas y tecnología a partir de un problema central real, haya aumentado el interés de las chicas por estos asuntos y, con ello, impulsado un alto desarrollo competencial escolar. En la misma línea, este alto desarrollo competencial escolar en la CMCT favorece el aumento de los factores psicológicos, como la autopercepción y la confianza en el propio potencial, que son variables importantes en la cuestión de brecha de género en las áreas STEM (Jiménez Iglesias et al., 2018; UNESCO, 2017). A nivel individual, la propia creencia de autoeficacia influye en las elecciones académicas y ocupacionales, ya que se prefiere o se elige aquellas áreas en las que uno se siente competente (Bleeker y Jacobs, 2004), es decir, se encuentra capaz de realizar las acciones que se requieren para alcanzar un resultado deseado. Así, en los campos donde se presume que se requiere un talento innato para tener éxito - una cualidad generalmente asociada a los hombres-, las mujeres tienden a estar subrepresentadas, por ejemplo, en las ingenierías y la física.

Como se ha comentado, se procede a establecer algunas comparaciones entre los resultados aquí obtenidos y los derivados de los estudios que más cercanos hemos encontrado a esta temática. Dentro de este escaso corpus, la mayoría de los estudios que han aplicado algún tipo de educación STEAM curricular o extracurricularmente con alumnado de etapas de Educación Infantil, Educación Primaria o ESO, han evaluado aspectos conceptuales o procedimentales — habilidades - demostrando la eficacia de este enfoque (Alsina y Acosta Inchaustegui, 2018; Cools, Conradie, Ciocci y Saldien, 2018; Engelman et al., 2017; Iglesias Albarrán, 2017; Jeong y Kim, 2015, Kim y Chae, 2016; Kim, Kim y Park, 2014; Liliawati, Rusnayati, Purwanto y Aristantia, 2018; Park y Lee, 2014; Ruiz Vicente, 2017).

Otros han detectado mejoras en el empoderamiento, el interés, el compromiso o la motivación del alumnado (Alsina y Salgado, 2018; Barnes, FakhrHosseini, Vasey, Duford y Jeon, 2017; Barnes, FakhrHosseini, Vasey, Park y Jeon, 2019; Dejarnette, 2018; Engelman et al., 2017; Iglesias Albarrán, 2017; Karageorgiou, Mavrommati y Fotaris, 2019; Kim, Ko, Han y Hong, 2014; Song et al., 2019).

Muchos menos estudios han hecho referencia al desarrollo competencial escolar. En este sentido, Alsina y Salgado (2018) llevaron a cabo 
una actividad STEAM con 85 alumnos de Educación Infantil de tres a seis años advirtiendo que este trabajo contribuyó al desarrollo su competencia matemática. Kim y Bastani (2017) llevaron a cabo un estudio con 60 estudiantes de Secundaria que se sumergieron en una propuesta STEAM de diseño de juegos, afirmando que el desarrollo de las competencias transdisciplinarias STEAM - pensamiento crítico y pensamiento sistémico para la resolución de problemas complejos y la toma de decisiones- de los estudiantes puede contribuir a su aprendizaje individual y colectivo de múltiples disciplinas. Engelman et al. (2017) utilizaron la herramienta educativa EarSketch bajo un enfoque STEAM y encontraron en su muestra de 74 estudiantes de Secundaria una mejora, en este caso, de la dimensión actitudinal de la competencia en computación. Duban, Aydoğdu y Kolsuz (2018) implementaron un conjunto de actividades STEAM relacionadas con la electricidad en una muestra de 25 estudiantes de cuarto curso de Educación Primaria encontrando una mejora en la dimensión actitidinal de la competencia científica.

Todos estos resultados parecen ser congruentes con los obtenidos en esta investigación, donde el desarrollo de los aspectos actitudinales, motivacionales, conceptuales y procedimentales del conjunto de competencias clave, también han resultado ser positivos.

Por último, recordar que el desarrollo competencial escolar aquí evaluado en la muestra de 121 alumnos de sexto de Educación Primaria tras la implementación de una UD STEAM integrada ha alcanzado el nivel superior, tanto en la CG como en el resto de las competencias clave evaluadas - CCL, CMCT, CD, CPAA, SIE, CEC, CSC—, según los cuatro niveles establecidos. A juzgar por todo este panorama, parece apropiado afirmar que la educación STEM/STEAM integrada se presenta como un enfoque potente para el desarrollo de todo el abanico competencial escolar en chicos y chicas y, en particular, para la mejora sustancial de la CMCT en las chicas, con todo lo que esto parece implicar.

En cuanto al segundo de los asuntos, la evaluación de las actitudes hacia la ciencia y las intenciones hacia la ciencia, la ingeniería y su conjunto, resulta interesante realizar una comparación de los valores aquí obtenidos en dos de los constructos con los reportados en el único estudio que, hasta la fecha, dada su novedad, ha empleado el mismo instrumento. En la Tabla 7.28 se presenta esta comparación. 
Tabla 7.28. Comparación de medias obtenidas en dos constructos con el instrumento BRAINS con muestras de alumnado de sexto curso

\begin{tabular}{lll}
\hline & $\begin{array}{l}\text { Resultados obtenidos } \\
\text { esta tesis doctoral }\end{array}$ & $\begin{array}{l}\text { Resultados reportados por Summers } \\
\text { y Abd-El-Khalick (2019) }\end{array}$ \\
& $\mathrm{N}=117$ & $\mathrm{~N}=215$ \\
\hline $\begin{array}{l}\text { Actitudes } \\
\text { ciencia }\end{array}$ & 4.16 & 3.60 \\
\hline $\begin{array}{l}\text { Intención } \\
\text { ciencia }\end{array}$ & 3.17 & 2.92 \\
\hline
\end{tabular}

Como se puede observar, los valores obtenidos en esta investigación son superiores a los reportados por Summers y Abd-El-Khalick (2019) en referencia a su porción de muestra de estudiantes de sexto de Educación Primaria de Illinois. A falta de la comparación con más estudios, los resultados obtenidos en esta tesis doctoral parecen mostrar la potencialidad de la implementación de la UD STEAM integrada para el desarrollo de actitudes positivas hacia la ciencia e intención de seguir en un futuro estudios de ciencias.

Por otra parte, la literatura muestra que existe un declive en las actitudes hacia la ciencia en los últimos cursos de la Educación Primaria tanto a nivel nacional (Marbà-Tallada y Márquez Bargalló, 2010; de Pro Bueno y Pérez Manzano, 2014; Toma, Ortiz-Revilla y Greca, 2019; Vázquez Alonso y Manassero Mas, 2008) como internacional (Akpinar et al., 2009; Ali et al., 2013; Denessen, Vos, Hasselman y Louws, 2015; DeWitt y Archer, 2015; George, 2006; Pell y Jarvis, 2001; Said et al., 2016). Por el contrario, los resultados aquí obtenidos no coinciden con este patrón, pues en los valores del constructo Actitudes hacia la ciencia se ha observado una diferencia significativa entre el grupo de quinto curso y el de sexto curso a favor del último, lo que afianza la afirmación de la potencialidad de la UD STEAM integrada para el desarrollo, en este caso, de las actitudes hacia la ciencia.

En la literatura especializada también se ha mostrado de manera generalizada tanto a nivel nacional (Pérez Manzano y de Pro Bueno, 2018; de Pro Bueno y Pérez Manzano, 2014; Vázquez Alonso y Manassero Mas, 2008) 
como internacional (Boone, 1997; Caleon y Subramaniam, 2008; Denessen et al., 2015; DeWitt y Archer, 2015; George, 2006; Hacieminoglu, 2016; Jarvis y Pell, 2005) que los chicos presentan mejores actitudes hacia la ciencia que las chicas. Los resultados aquí obtenidos no concuerdan con esta tendencia, al menos, para las actitudes hacia la ciencia, donde los valores obtenidos son iguales para ambos géneros. Solamente aparecen diferencias significativas en el constructo Intención ingeniería, lo que podría estar relacionado con las temáticas preferidas por las chicas, dado que algunos estudios relacionan el interés de las chicas en áreas STEM con la relevancia social percibida (Blanchard Kyte y Riegle-Crumb, 2017).

Por último, la comparación entre la CMCT y los constructos de actitudes e intenciones parece mostrar que un aumento en la CMCT se relaciona con una mejora de las actitudes hacia la ciencia, resultado que concuerdan con la tendencia reportada en la literatura (MECD, 2016b). Sin embargo, la misma relación no se observa entre la CMCT y las intenciones, que representan un constructo más lento de modificar que las actitudes.

En cuanto al tercero de los asuntos, las mejoras a realizar en el conjunto de los prototipos de la UD, destacar que la detección de menor número de carencias y, con ello, de modificaciones en los sucesivos prototipos de la UD, parece avalar la viabilidad de la investigación de diseño para el desarrollo de propuestas didácticas STEAM integradas. Esta afirmación se refuerza si se atiende al punto de vista de los maestros, quienes consideraron que no sería necesario realizar más modificaciones en el último prototipo de la UD para cumplir con las obligaciones curriculares y que el alumnado alcanzara un nivel competencial adecuado. Al respecto, cabe destacar que Quigley y Herro (2016) examinaron la implementación de prácticas de enseñanza STEAM en una muestra de 21 profesores de ciencias y matemáticas de Secundaria detectando que, aunque muchas de las prácticas ayudaron en el aprendizaje de los estudiantes, la educción STEAM implica cambios importantes en la práctica de la enseñanza para muchos profesores, llevando un tiempo refinarla e implementarla de manera efectiva, cuestión con la que acordamos plenamente. Sin embargo, destacamos que, en el caso de esta tesis doctoral, el desarrollo de la primera versión de la UD, consensuando el tema con los maestros y ateniéndose a los objetivos curriculares —es decir, con un enfoque claro en el desarrollo competencial escolar según los EAE — y en un período de tiempo razonable dentro de la dinámica escolar, hizo que el proceso de adaptación 
fuera bastante rápido. De hecho, las modificaciones del primer prototipo al segundo, aunque implicaron ganancias en el desarrollo competencial escolar del alumnado, fueron refinamientos menores. Es decir, desde un inicio se intentó, mediante el envolvimiento directo de los maestros, evitar las quejas que Cañal (2007) recoge como típicas de los maestros ante la realización de estos cambios: no fueron necesarios grandes cambios en las aulas, en la organización curricular o en el tiempo destinado.

En esta línea conviene destacar que no se encontraron diferencias significativas entre grupos en el desarrollo competencial escolar alcanzado. Es decir, el alumnado alcanzó el desarrollo independientemente del maestro — sus características personales, formación, motivación, afinidad por las ciencias, etc.- Como ya se indicó, se deben tener en cuenta las características particulares de esta implementación —corta duración y altamente motivadora - por ser diferente, para maestros y alumnado, cuestión que podría explicar parte de esta independencia de resultados en relación con los estilos didácticos de los maestros. Sin embargo, cabe por último resaltar el interés mostrado por todos los maestros participantes, quienes solicitaron de nuevo todo el material para poder volver a realizar la implementación STEAM en el siguiente curso académico. 


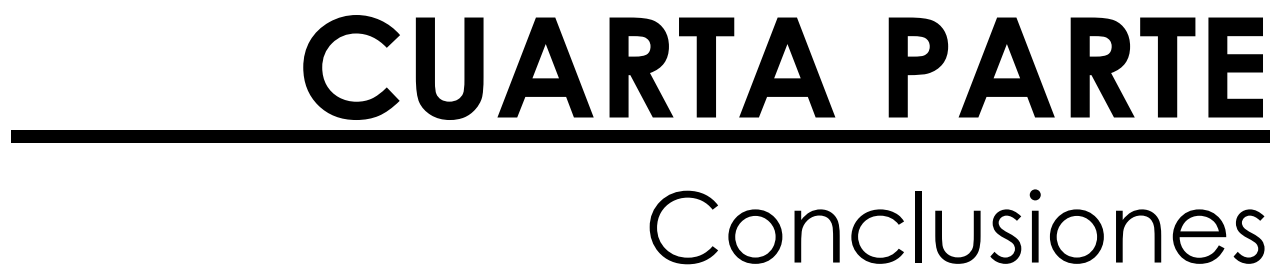





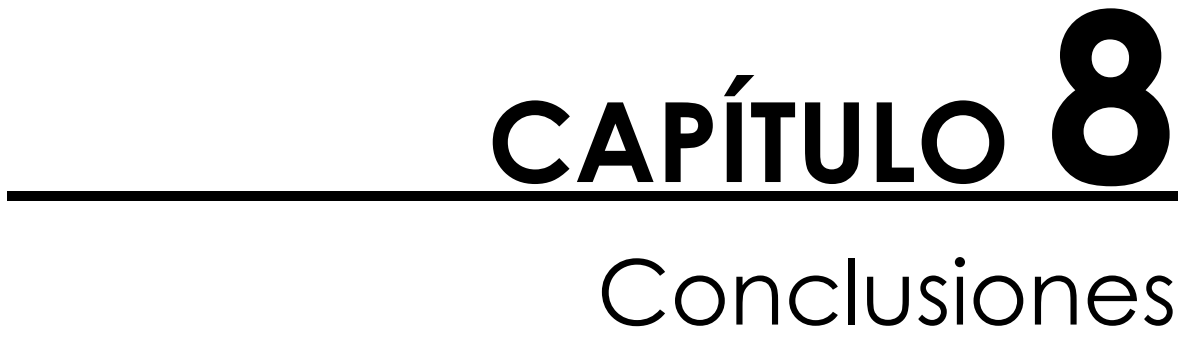



7 ara finalizar con esta tesis doctoral, que ha pretendido proporcionar un panorama innovador en relación con la adquisición de las competencias clave en la Educación Primaria a través del cambio metodológico, este capítulo recoge un conjunto de conclusiones acerca de las implicaciones educativas de la educación STEM/STEAM integrada en relación con su potencialidad para la mejora del desarrollo competencial escolar del alumnado de esta etapa. Para ello, se va respondiendo de manera concisa a cada una de las preguntas de investigación planteadas inicialmente. A continuación, se atiende a las limitaciones encontradas y, por último, se determinan algunas futuras líneas de investigación derivadas de los hallazgos de la presente tesis doctoral.

\subsection{Respuestas encontradas a las preguntas de investigación planteadas}

$\mathrm{Al}$ inicio de esta tesis doctoral establecimos cuatro preguntas de investigación - P 1, P 2, P 3 y P 4-, para cuya respuesta fueron planteados cuatro objetivos generales de los que, en determinados casos, se derivaron algunos objetivos específicos, así como sus correspondientes tareas a realizar. Después del camino recorrido a lo largo de los siete capítulos anteriores, en los que se realizaron las tareas y se alcanzaron los objetivos generales y específicos, nos proponemos sintetizar los principales asuntos tratados respondiendo brevemente a cada una de las cuatro preguntas de investigación.

La P 1 rezaba: ¿Qué elementos son necesarios para construir una fundamentación teórica coherente para la educación STEM/STEAM integrada enfocada a la potenciación del desarrollo competencial integral del alumnado de Educación Primaria? La respuesta a esta pregunta abarcó las investigaciones que aparecen en los Capítulos 2, 3 y 4 y que comenzó con la elucidación de lo que implica el constructo competencial. La realización de la revisión bibliográfica sistemática y crítica sobre la investigación acerca de las competencias en la Educación Primaria puso de manifiesto la complejidad que este constructo implica, las diferentes conceptualizaciones que, desde su origen, han balizado el debate competencial, así como la escasa investigación realizada sobre las competencias en Educación Primaria, a pesar de su omnipresencia en los documentos educativos. En esta búsqueda adoptamos dos compromisos 
teóricos que guiaron los posteriores desarrollos de la tesis doctoral. Por una parte, nos adherimos a una visión humanista en relación con el desarrollo competencial escolar, en línea con la visión de la UNESCO, encaminada a la educación integral de la persona. Por la otra, y estrechamente vinculada con la anterior, consideramos que para alcanzar esa educación integral es necesario entender el constructo desde una visión multidimensional amplia, habiéndose adoptado una comprensión de la competencia que abarca siete dimensiones: conceptual, procedimental, actitudinal, contextual, comunicativa, metacognitiva y epistemológica.

Por su parte, el análisis transversal de las diferentes implicaciones educativas que el desarrollo competencial escolar implica para la etapa de Educación Primaria en general y, en particular, con los compromisos adoptados, reveló la necesidad de un cambio metodológico encaminado hacia propuestas transdiciplinarias, lo que nos llevó a enfocarnos hacia las propuestas recientes en torno a los enfoques STEM/STEAM integrados. Con esta premisa como punto de partida, se determinaron los fundamentos teóricos de la educación STEM/STEAM integrada y sus posibles potencialidades para el desarrollo competencial escolar en la Educación Primaria. Esta fundamentación teórica se sustentó en la red triádica propuesta por Laudan, que guio a la elección de las metodologías didácticas y las teorías que fueran compatibles con los fines perseguidos. Así, fue posible conciliar los fines -el desarrollo competencial integral - con determinadas metodologías didácticas - metodologías activas, centradas en la resolución de problemas, como la metodología de indagación, el diseño de ingeniería, etc.- , las cuales, a su vez, fueron sustentadas por ciertas teorías epistemológicas - la propuesta por el propio Laudan, que entiende la ciencia como resolución de problemas-, psicológicas - Vergnaud y su concepción de que el dominio de un campo conceptual implica que el individuo se enfrente a un conjunto grande y variado de situaciones que debe resolver - y didácticas — la idea de objetivosobstáculos de Martinand como punto de partida para el diseño de secuencias didácticas-. Consideramos que conseguimos establecer así una fundamentación teórica coherente y robusta para la educación STEM/STEAM integrada enfocada a la potenciación del desarrollo competencial integral del alumnado de Educación Primaria, que tuvo en cuenta su complejidad y superó la concepción superficial expandida del constructo competencial. 
Por otra parte, mientras avanzábamos en las discusiones teóricas y en la implementación didáctica, surgió la pregunta sobre cómo podría entenderse la naturaleza del conocimiento integrado y transdisciplinario propuesto por la educación STEM/STEAM integrada. Así, analizamos las relaciones actuales entre el conocimiento producido por las áreas de ciencia, tecnología, ingeniería y matemáticas, lo que nos llevó a adoptar un modelo de «tejido sin costuras». Algunos de los tópicos que emergieron de esta adopción fueron considerados desde la perspectiva del modelo filosófico del «parecido de familia» para determinar unos rasgos potenciales para una NOSTEM.

Con todo esto, consideramos que este conjunto de conceptualizaciones permite dar respuesta a la $\mathrm{P} 1$ de investigación.

La respuesta a la P 2 - ¿Resulta plausible diseñar e implementar satisfactoriamente una UD STEAM enfocada al desarrollo competencial en la etapa de Educación Primaria?-aparece en los Capítulos 5, 6 y 7. Comenzamos diseñando, a partir del marco teórico desarrollado para dar respuesta a la P 1, una UD desde un enfoque STEAM integrado, con el uso de las metodologías de indagación y del diseño de ingeniería. En este diseño desarrollamos un modelo propio de integración- que parte de un problema inicial, cuya resolución mediante un diseño de ingeniería al final de la UD es posible dados los conocimientos y competencias adquiridos por los alumnos por medio de indagaciones guiadas previas en las áreas de Matemáticas, Ciencias de la Naturaleza y Educación Plástica-. Destacamos que, a diferencia de lo que ocurre en la mayoría de las propuestas STEAM, aquí consideramos el valor intrínseco de la $\mathrm{A}$, abordándose de forma expresa contenidos curriculares del área artística —en este caso Educación Plástica- y no solamente como motivación para el aprendizaje de ciencias o incentivo a la creatividad.

Esta UD fue testada en seis grupos de sexto curso de Educación Primaria. Dado que el estudio de la viabilidad de una propuesta didáctica debería tener en consideración las situaciones reales de aula, incluyendo a los maestros, este estudio se realizó usando la investigación de diseño. A la luz de los resultados obtenidos parece coherente considerar la investigación de diseño como un paradigma metodológico plausible para el diseño, la implementación y la evaluación de propuestas didácticas STEAM integradas en contextos naturales de Educación Primaria. De hecho, hemos podido elucidar algunos asuntos que bien podrán servir como directrices para guiar futuros diseños. Además, el valor de este paradigma se ha visto reforzado tanto por la 
consecución del objetivo de aprendizaje propuesto — habiéndose registrado en las tres implementaciones evidencias de altos niveles de desarrollo competencial escolar del alumnado- como por la superación, por parte de los maestros participantes, de algunas de las concepciones habituales que ponen en duda el uso de metodologías activas, como la imposibilidad del tratamiento íntegro de los contenidos curriculares (Cañal, 2007). También comprobamos que no existieron diferencias significativas entre los distintos grupos, lo que evidenció la viabilidad de este tipo de propuestas en la Educación Primaria con independencia de las características de los maestros - formación, motivación, vínculo con la ciencia, etc.- .

Con respecto a la P 3 - ¿Qué efectos produce la implementación de una UD STEAM integrada en el desarrollo competencial del alumnado de Educación Primaria? - nos propusimos determinar la influencia de la implementación de nuestra UD STEAM integrada analizando los efectos en torno a dos planos: el plano competencial general y el plano actitudinal, resultados presentados en el Capítulo 7. Los resultados obtenidos nos permiten responder a esta pregunta afirmando que, en este caso, la implementación de una UD STEAM ha producido un desarrollo competencial escolar alto y notablemente más elevado que el derivado de una metodología tradicional tal y como comentamos en la discusión con los resultados procedentes de la Evaluación fin de etapa 2017-2018 de CyL y del Informe PISA 2015-, tanto en la CG del alumnado como en las siete competencias clave propuestas en el currículo oficial. Es importante destacar este resultado, dado que las pocas evaluaciones existentes en torno a implementaciones de propuestas STEAM integradas en la Educación Primaria evalúan prioritariamente conocimientos o competencias ligadas fundamentalmente a la ciencia, la tecnología y las matemáticas. Lo que se ha encontrado en esta tesis doctoral, y en consonancia con el referencial teórico que hemos desarrollado para las propuestas STEAM integradas, es que este tratamiento transdisciplinario permite desarrollar de forma satisfactoria todas las competencias clave, al menos en la etapa de Primaria.

Los resultados en el plano actitudinal no han sido menos satisfactorios. Los constructos evaluados, relacionados con las actitudes hacia la ciencia y las intenciones hacia la ciencia, la ingeniería y su conjunto, han reportado niveles de nuevo notablemente más altos que en otros contextos para alumnado de estas edades — tal y como comentamos en la discusión con los resultados 
reportados por la literatura especializada y concretamente por Summers y AbdEl-Khalick (2019)—, lo que permite afirmar que la implementación de una UD STEAM también ha producido, en este caso, efectos positivos en el plano actitudinal.

Destacamos especialmente el efecto positivo que ha tenido esta UD en las chicas. Por una parte, han conseguido niveles competenciales más altos en la CMCT que los chicos, en contraposición con los datos que sistemáticamente se obtienen tanto a nivel regional como europeo (JCyL, 2018; OECD, 2016). Por la otra, sus actitudes e intención hacia la ciencia han sido tan altas como las de los chicos, habiendo existencia de diferencias significativas a favor de éstos solamente en el constructo de Intención hacia la ingeniería.

En cuanto a la P 4 - ¿Qué panorama alternativo a la enseñanza tradicional se presenta prometedor para mejorar el desarrollo competencial del alumnado de Educación Primaria?_- recogiendo las aportaciones de esta tesis doctoral y a través del conjunto de conclusiones ya presentadas se evidencia que la educación STEM/STEAM integrada, materializada a través de metodologías activas, como en este caso la indagación y el diseño de ingeniería, se presenta como una posible vía de mejora del desarrollo competencial escolar en toda su complejidad del alumnado de Educación Primaria. En consecuencia, consideramos a este enfoque como una alternativa potente para contribuir a subsanar las carencias de desarrollo competencial escolar que hoy en día sigue perpetuando la educación tradicional tanto en España como en muchos otros lugares.

\subsection{Limitaciones}

Si bien consideramos haber contribuido con rigor al crecimiento del conocimiento en el campo de la Didáctica de las Ciencias Experimentales, esta investigación no ha estado exenta de limitaciones que, aunque ya esbozadas en su momento, merece la pena concretar y evaluar.

Por razones de espacio del correspondiente artículo científico, aunque la revisión sistemática de la investigación acerca del constructo competencial en la etapa de Educación Primaria incluyó revistas de otros países indizadas en el ranking de calidad JCR, sin embargo, así como sí se realizó con España obteniendo valiosa información, no se incluyeron revistas de justificada calidad 
de otros países. Se trata de una cuestión que sería interesante atender en futuros estudios, ya que podría contribuir a ampliar los conocimientos sobre el constructo competencial.

Como ya se comentó, por razones temporales vinculadas al desarrollo de la tesis doctoral, no se abordaron de manera explícita en la propuesta didáctica elementos de la NOSTEM presentados en la fundamentación teórica previa. Sin embargo, creemos que son necesarias propuestas transdisciplinarias que engloben esta dimensión competencial, nombrada también como naturaleza del conocimiento disciplinar en el desarrollo de la conceptualización del constructo competencial - y válida para el resto de las disciplinas-. Por tanto, sería interesante, que nuevas propuestas STEM/STEAM integradas comenzaran a incluir esta dimensión y a evaluar sus efectos en la alfabetización científico-tecnológica del alumnado.

Una tercera limitación surgió derivada del diseño metodológico de la tesis doctoral. En esta ocasión no fue posible la aplicación como pre-test de la adaptación al español del instrumento de evaluación de actitudes hacia la ciencia BRAINS. Por tanto, aunque se pudieron establecer tamaños de efecto derivados de la implementación didáctica utilizando una muestra de quinto de Educación Primaria del mismo centro, no fue posible establecer correlaciones más directas entre el desarrollo competencial escolar y el actitudinal e intencional del alumnado. Así, estudios en este sentido se presentan adecuados para seguir enriqueciendo los hallazgos de esta investigación encontrados en este sentido.

Por último, en relación con el foco de la investigación, esta tesis doctoral no ha presentado la parte más vivencial del trabajo que desarrollamos junto a maestros y alumnado. Es decir, no se han presentado resultados relativos a la visión de los maestros y del alumnado del enfoque STEAM integrado implementado, aunque disponemos de numerosas evidencias sobre la motivación que la implementación de la UD supuso para todos los implicados.

\subsection{Futuras líneas de investigación}

Ante el panorama emergente fruto de la presente tesis doctoral, se abre un amplio horizonte de posibles futuras líneas de investigación que conviene recoger y organizar aquí en pro de seguir mostrando evidencias de la viabilidad 
y la importancia de la aplicación de propuestas transdisciplinarias para la potenciación del desarrollo competencial escolar del alumnado de Educación Primaria, concretamente desde un enfoque STEM/STEAM integrado.

En primer lugar, entendemos que, si bien la conceptualización del constructo competencial ha permeado con fuerza en el ámbito educativo, se debe seguir trabajando en torno a la comprensión de su conceptualización, superando, como aquí se ha demostrado, la generalizada y superficial idea de que este enfoque no introduce grandes novedades respecto a lo ya existente y comprendiendo que se trata de una oportunidad que no debería dejarse pasar (Valle y Manso, 2013). Se trata de una oportunidad única para reflexionar de nuevo sobre las finalidades de la educación básica (Izquierdo Aymerich, 2012); para preparar a los individuos a vivir en los actuales contextos de complejidad (Pérez Gómez, 2008); para reflexionar también sobre la práctica y optimizar la calidad de la enseñanza (Rosselló Ramón y Pinya Medina, 2014); para reconocer competencias paradigmáticas (Adúriz-Bravo, 2017); para relacionar los conocimientos con las prácticas sociales y, por tanto, comprender su sentido y alcance (Perrenoud, 2009); para llevar a la práctica propuestas que integren problemas cotidianos (España, Cabello y Blanco, 2014); en suma, una oportunidad para que el sistema educativo afronte la educación desde un prisma racional y con un compromiso social (Zabala y Arnau, 2007). También resulta imprescindible, desde nuestro punto de vista, seguir reflexionando acerca de su evaluación, con la intención de que maestros y profesorado puedan adoptar el enfoque competencial de una manera confiada, rigurosa y significativa en el alumnado, cuestión que no se ha facilitado desde la legislación.

En segundo lugar, en el camino hacia la construcción del encuadre teórico para la educación STEM/STEAM integrada, en nuestro artículo de posición adoptamos un conjunto particular de teorías que, como comentamos, podrían haber limitado la investigación teórica. Por tanto, sugerimos que podrían ampliarse algunos aspectos teóricos específicos, así como adoptarse otras construcciones teóricas diferentes a las se propusieron, siempre y cuando se mantenga la correspondiente coherencia entre fines, teoría y métodos.

En tercer lugar, y como hemos dejado patente, confiamos en el poder de la discusión epistemológica para seguir perfilando algunos rasgos potenciales para una naturaleza de la educación STEM/STEAM integrada. En esta tesis doctoral establecimos un marco inicial para este debate. Por tanto, 
consideramos primordial seguir trabajando en esta línea, siempre teniendo en cuenta que la adopción de una determinada visión epistemológica tendrá implicaciones en los objetivos de la educación general y en la construcción de la sociedad en su conjunto. Por ello, apostamos por una ampliación del FRA para una NOSTEM basada en una perspectiva humanista.

En cuarto lugar, se deben seguir aunando esfuerzos para conseguir que las mujeres, en este caso a través de la educación STEM/STEAM integrada, puedan llegar a sentirse totalmente partícipes del proceso de enseñanzaaprendizaje — en este caso con una especial mirada hacia la ciencia escolar- y desarrollar una alfabetización integral en igualdad de condiciones. En este sentido, creemos que sería importante evaluar qué tipos de problemas podrían incentivar la intención de seguir carreras de ingeniería en las chicas.

En quinto y último lugar, pero no por ello de menos importancia, instamos a que se sigan realizando implementaciones tanto en la Educación Primaria como en la ESO encaramadas en enfoques STEM/STEAM integrados. Como se ha comprobado, la literatura al respecto resulta limitada, siendo necesario ampliar esta aún incipiente línea de investigación para poder seguir descubriendo sus posibles beneficios tanto para el campo de la didáctica de las ciencias como para la educación en general. 


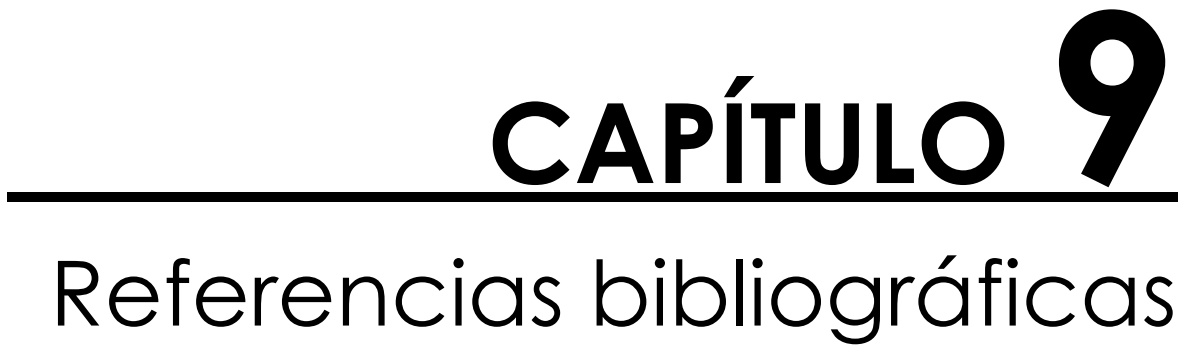



Acaso, M. (2013). rEDUvolution: hacer la revolución en la educación. Barcelona, España: Paidós.

Acaso, M. (2014). La educación artística no son manualidades: nuevas prácticas en la enseñanza de las artes y la cultura visual (3rd ed.). Madrid, España: Catarata.

Adúriz-Bravo, A. (2005). Una introducción a la naturaleza de la ciencia. La epistemología en la enseñanza de las ciencias naturales. Buenos Aires, Argentina: Fondo de Cultura Económica.

Adúriz-Bravo, A. (2017). Pensar la enseñanza de la física en términos de "competencias". Revista de Enseñanza de la Física, 29(2), 21-31. Recuperado de https://revistas.unc.edu.ar/index.php/revistaEF/article/view/18801 $/ 18655$

Adúriz-Bravo, A., Merino, C., Jara, R., Arellano, M., y Ruiz, F. J. (2012). Competencias científicas: ¿desde dónde y hacia dónde? En E. Badillo, L. García, A. Marbà y M. Briceño (Eds.), El desarrollo de competencias en la clase de ciencias y matemáticas (pp. 17-42). Mérida, Venezuela: Universidad de Los Andes.

Acevedo Díaz, J. A. (2008). El estado actual de la naturaleza de la ciencia en la didáctica de las ciencias. Revista Eureka sobre Enseñanza y Divulgación de las Ciencias, $\quad$ 5(2), 134-169. doi:10.25267/Rev_Eureka_ensen_divulg_cienc.2008.v5.i2.02

Aesaert, K., y van Braak, J. (2015). Gender and socioeconomic related differences in performance based ICT competences. Computers \& Education, 84, 8-25. doi:10.1016/j.compedu.2014.12.017

Aesaert, K., van Braak, J., van Nijlen, D., y Vanderlinde, R. (2015). Primary school pupils' ICT competences: Extensive model and scale development. Computers \&. Education, 81, 326-344. doi:10.1016/j.compedu.2014.10.021

Aesaert, K., van Nijlen, D., Vanderlinde, R., Tondeur, J., Devlieger, I., y van Braak, J. (2015). The contribution of pupil, classroom and school level characteristics to primary school pupils' ICT competences: A performance-based approach. Computers \&. Education, 87, 55-69. doi:10.1016/j.compedu.2015.03.014 
Aesaert, K., van Nijlen, D., Vanderlinde, R., y van Braak, J. (2014). Direct measures of digital information processing and communication skills in primary education: Using item response theory for the development and validation of an ICT competence scale. Computers \& Education, 76, 168-181. doi:10.1016/j.compedu.2014.03.013

Aguilera Morales, D., Martín-Páez, T., Valdivia-Rodríguez, V., Ruiz-Delgado, A., Willians-Pinto, L., Vílchez-González, J. M., y Perales-Palacios, F. J. (2018). La enseñanza de las ciencias basada en indagación. Una revisión sistemática de la producción española. Revista de Educación, 381, 259284. doi:10.4438/1988-592X-RE-2017-381-388

Aikenhead, G. (2003). STS education: a rose by any other name. En R. Cross (Ed.), A vision for science education: responding to the work of Peter J. Fensham (pp. 59-75). Londres, Inglaterra: RoutledgeFalmer.

Aikenhed, G. (2015). Humanist perspectives on science education. En R. Gunstone (Ed.), Encyclopedia of science education (pp. 467-471). Dordrecht, Países Bajos: Springer.

Akerson, V. L., Burgess, A., Gerber, A., Guo, M., Khan, T. A., y Newman, S. (2018). Disentangling the meaning of STEM: implications for science education and science teacher education. Journal of Science Teacher Education, 29(1), 1-8. doi:10.1080/1046560x.2018.1435063

Akpınar, E., Yıldız, E., Tatar, N., y Ergin, Ö. (2009). Students' attitudes toward science and technology: an investigation of gender, grade level, and academic achievement. Procedia Social and Behavioral Sciences, 1(1), 28042808. doi:10.1016/j.sbspro.2009.01.498

Alcaraz Salarirche, N., Caparrós Vida, R. M., Soto Gómez, E., Beltrán Duarte, R., Rodríguez Sánchez, A., y Sánchez García, S. (2013). ¿Evalúa PISA la competencia lectora? Revista de Educación, 360, 577-599. doi:10.4438/1988-592X-RE-2011-360-130

Ali, M. M., Yager, R., Hacieminoglu, E., y Caliskan, I. (2013). Changes in student attitudes regarding science when taught by teachers without experiences with a model professional development program. School Science and Mathematics, 113(3), 109-119. doi:10.1111/ssm.12008

Almerich, G., Díaz-García, I., Cebrián-Cifuentes, S., y Suárez-Rodríguez, J. (2018). Estructura dimensional de las competencias del siglo XXI en 
alumnado universitario de educación. RELIEVE, 24(1), 1-21. doi:10.7203/relieve.24.1.12548

Alsina, Á., y Acosta Inchaustegui, Y. (2018). Iniciación al álgebra en Educación Infantil a través del pensamiento computacional: una experiencia sobre patrones con robots educativos programables. UNIÓN, Revista Iberoamericana de Educación Matemática, 52, 218-235. Recuperado de http://www.fisem.org/www/union/revistas/2018/52/10.pdf

Alsina, Á., y Salgado, M. (2018). Land Art Math: una actividad STEAM para fomentar la competencia matemática en Educación Infantil. Edma 0-6: Educación Matemática en la Infancia,7(1), 1-11. Recuperado de http://www.edma0-6.es/index.php/edma0-6/article/view/48/37

American Association for the Advancement of Science. (1993). Benchmarks for science literacy. Nueva York, NY: Oxford University Press.

American Psychological Association. (2017). Ethical principles of psychologists and code of conduct. Recuperado de https://www.apa.org/images/ethicscode-2017_tcm7-218783.pdf

Anderson, T., y Shattuck, J. (2012). Design-Based Research: a decade of progress in education research. Educational Researcher, 41(1), 16-25. doi:10.3102/0013189X11428813

Anderson, C., y Smith, E. (1986). Children's conceptions of light and color: understanding the role of unseen rays. East Lansing, MI: Michigan State University, Institute for Research on Teaching.

Andreu Duran, M., y Godall Castell, P. (2012). La importancia de la educación artística en la enseñanza obligatoria: la adquisición de las competencias básicas de Primaria en un centro integrado de música. Revista de Educación, 357, 179-202. doi:10-4438/1988-592X-RE-2010-357-057

Andreu Duran, M., Godall Castell, P., Amador Guillem, M., y Castro Morera, M. (2017). Study of the results in the acquisition of core competencies in schools that integrate primary education and music. International Journal of Music Education, 35(4), 554-564. doi:10.1177/0255761416689845 
Angulo Rasco, J. F. (1994). ¿'A qué llamamos curriculum? En J. F. Angulo Rasco y N. Blanco (Coords.), Teoría y desarrollo del curriculum (pp. 17-29). Málaga, España: Aljibe.

Antink-Meyer, A., y Brown, R. A. (2019). Nature of engineering knowledge: an articulation for science learners with nature of science understandings. Science \& Education, 28(3-5), 539-559. doi:10.1007/s11191-019-00038-0

Arillo, M. A., Ezquerra, A., Fernández, P., Galán, P., García, E., González, M., ... San Martín, C. (2013). Las ideas «cientificas» de los alumnos y alumnas de Primaria: tareas, dibujos y textos. Madrid, España: Universidad Complutense de Madrid.

Arriassecq, I., Greca, I. M., y Cayul, E. E. (2017). Secuencias de enseñanza y aprendizaje basadas en resultados de investigación: propuesta de un marco teórico para el abordaje de la teoría especial de la relatividad. Enseñanza de las Ciencias, 35(1), 133-155. doi:10.5565/rev/ensciencias. 1716

Artigue, M. (1988). Ingénierie didactique. Recherches en Didactique des Mathématiques, 9(3), 281-308. Recuperado de http://rdm.penseesauvage.com/Ingenierie-didactique.html

Association of American Universities. (2011). Five-year initiative for improving undergraduate STEM education: discussion draft. Recuperado de https://www.aau.edu/sites/default/files/STEM

Scholarship/AAU_STEM_Initiative_Discussion_Draft.pdf

Astolfi, J. P. (1988). El aprendizaje de conceptos científicos: aspectos epistemológicos, cognitivos y lingüísticos. Enseñanza de las Ciencias, 6(2), 147-155. Recuperado de http://www.raco.cat/index.php/Ensenanza/article/view/51080/927 51

Astolfi, J. P. (1994). El trabajo didáctico de los obstáculos, en el corazón de los aprendizajes científicos. Enseñanza de las Ciencias, 12(2), 206-216. Recuperado de http://www.raco.cat/index.php/Ensenanza/article/view/21359/947 04 
Astolfi, J. P. (1999). El tratamiento didáctico de los obstáculos epistemológicos. Revista Educación y Pedagogía, 11(25), 149-171. Recuperado de http://aprendeenlinea.udea.edu.co/revistas/index.php/revistaeyp/art icle/view/5863/5276

Astolfi, J. P., Darot, É., Ginsburger-Vogel, Y., y Toussaint, J. (1997). Mots-clés de la didactique des sciences. Repères, définitions, bibliographies. Bruselas, Bélgica: De Boeck Université.

Ata Aktürk, A., y Demircan, H. O. (2017). A review of studies on STEM and STEAM education in early childhood. Abi Evran Üniversitesi Kerşehir Eğitim Fakültesi Dergisi (KEFAD), 18(2), 757-776. Recuperado de http://kefad.ahievran.edu.tr/Kefad/ArchiveIssues/PDF/61a3ddc097d9-e711-80fc-00224d68272d

$\mathrm{Au}, \mathrm{W}$. (2009). Unequal by design: high-stakes testing and the standardization of inequality. Nueva York, NY: Routledge.

Australian Council of Learned Academies. (2013). STEM: country comparisons. Melbourne, Australia: Autor.

Ausubel, D. P. (1968). Educational psychology: a cognitive view. Nueva York, NY: Holt, Rinehart and Winston.

Avigad, J. (2008). Computers in mathematical inquiry. En P. Mancosu (Ed.), The philosophy of mathematical practice (pp. 302-316). Oxford, England: Oxford University Press.

Bachelard, G. (1938). La formation de l'esprit scientifique: contribution à une psychanalyse de la connaissance objective. París, Francia: Librairie Philosophique J. Vrin.

Bannan-Ritland, B. (2003). The role of design in research: the integrative learning design framework. Educational Researcher, 32(1), 21-24. doi:10.3102/0013189X032001021

Barab, S., y Squire, K. (2004). Design-based research: putting a stake in the ground. The Journal of the Learning Sciences, 13(1), 1-14. doi:10.1207/s15327809jls1301_1

Barnes, J., FakhrHosseini, M. S., Vasey, E., Duford, Z., y Jeon, M. (2017). Robot theater with children for STEAM education. Proceedings of the 
Human Factors and Ergonomics Society 2017 Annual Meeting, Austin, 61(1), 875-879. doi:10.1177/1541931213601511

Barnes, J., FakhrHosseini, S. M., Vasey, E., Park, C. H., y Jeon, M. (2019). Informal STEAM education case study: child-robot musical theater. CHI EA '19 Extended Abstracts of the 2019 CHI Conference on Human Factors in Computing Systems, Glasgow, LBW1111, 1-6. doi:10.1145/3290607.3312890

Barrios Espinosa, M. E., y Morales Orozco, L. (2012). Apoyo lingüístico inclusivo a alumnado no hispanohablante y aprendizaje de competencias curriculares en Educación Primaria. Porta Linguarum, 17, 203-221.

Recuperado

de https://dialnet.unirioja.es/servlet/articulo?codigo $=4589703$

Bequette, J. W., y Bequette, M. B. (2012). A place for art and design education in the STEM conversation. Art Education, 65(2), 40-47. doi:10.1080/00043125.2012.11519167

Bennett, J., Lubben, F., y Hogarth, S. (2007). Bringing science to life: a synthesis of the research evidence on the effects of context-based and STS approaches to science teaching. Science Education, 91(3), 347-370. doi:10.1002/sce.20186

Bennett, J., Lubben, F., Hogarth, S., y Campbell, B. (2005). Systematic reviews of research in science education: rigour or rigidity? International Journal of Science Education, 27(4), 387-406. doi:10.1080/0950069042000323719

Bevins, S., y Price, G. (2016). Reconceptualising inquiry in science education. International Journal of Science Education, 38(1), 17-29. doi:10.1080/09500693.2015.1124300

Biesta, G. (2007). Bridging the gap between educational research and educational practice: the need for critical distance. Educational Research and Evaluation, 13(3), 295-301. doi:10.1080/13803610701640227

Birch, K. (2013). The political economy of technoscience: an emerging research agenda. Spontaneous Generations: A Journal for the History and Philosophy of Science, 7(1), 49-61. doi:10.4245/sponge.v7i1.19556

Blanchard Kyte, S., Riegle-Crumb, C. (2017). Perceptions of the social relevance of science: exploring the implications for gendered patterns 
in expectations of majoring in STEM fields. Social Sciences, 6(1), 1-17. doi:10.3390/socsci6010019

Bleeker, M. M., y Jacobs, J. (2004). Achievement in math and science: do mothers' beliefs matter 12 years later? Journal of Educational Psychology, 96(1), 97-109. doi:10.1037/0022-0663.96.1.97

Bolívar, A. (2008). El discurso de las competencias en España: educación básica y educación superior. REDU. Revista de Docencia Universitaria, 6(2), 1-23. doi:10.4995/redu.2008.6268

Boon, M., y Knuuttila, T. (2009). Models as epistemic tools in engineering sciences. En A. Meijers (Ed.), Philosophy of technology and engineering sciences (pp. 693-726). Ámsterdam, Países Bajos: North Holland.

Boone, W. J. (1997). Science attitudes of selected middle school students in China: a preliminary investigation of similarities and differences as a function of gender. School Science and Mathematics, 97(2), 96-103. doi:10.1111/j.1949-8594.1997.tb17349.x

Borsa, J. C., Damàsio, B. F., y Bandeira, D. R. (2012). Cross-Cultural adaptation and validation of psychological instruments: some considerations. Paidéia, 22(53), 423-432. doi:10.1590/1982-43272253201314

Borwein, J., y Bailey, D. (2004). Mathematics by experiment: plausible reasoning in the 21st century. Natick, MA: AK Peters.

Breiner, J. M., Harkness, S. S., Johnson, C. C., y Koehler, C. M. (2012). What is STEM? A discussion about conceptions of STEM in education and partnerships. School Science and Mathematics, 112(1), 3-11. doi:10.1111/j.1949-8594.2011.00109.x

Broekkamp, H., y van Hout-Wolters, B. (2007). The gap between educational research and practice: a literature review, symposium, and questionnaire. Educational Research and Evaluation, 13(3), 203-220. doi:10.1080/13803610701626127

Brown, A. L. (1992). Design experiments: theoretical and methodological challenges in creating complex interventions in classroom settings. The Journal of the Learning Sciences, 2(2), 141-178. doi:10.1207/s15327809j1s0202_2 
Brown, J. (2012). The current status of STEM education research. Journal of STEM Education, 13(5), 7-11. Recuperado de http://litee.org/jstem/index.php/JSTEM/article/view/1652/1490

Bush, V. (1945). Science, the endless frontier. A report to the president. Recuperado del sitio de Internet de National Science Foundation: https://www.nsf.gov/about/history/nsf50/vbush1945.jsp

Buty, C., Tiberghien, A., y Le Maréchal, J. F. (2004). Learning hypotheses and an associated tool to design and to analyse teaching-learning sequences. International Journal of Science Education, 26(5), 579-604. doi:10.1080/09500690310001614735

Bybee, R. W. (2010). Advancing STEM education: a 2020 vision. Technology and Engineering Teacher, 70(1), 30-35. Recuperado de https://www.iteea.org/Publications/Journals/TET/TETSeptember2 010.aspx

Bybee, R. W. (2013). The case for STEM education: challenges and opportunities. Arlington, VA: NSTA.

de la Caba Collado, M. A., y López Atxurra, R. (2005). Actividades de participación y desarrollo de competencias de ciudadanía en los libros de texto de Educación Primaria de la Comunidad Autónoma Vasca (Conocimiento del Medio). Revista de Educación, 336, 377-396. Recuperado de http://www.mecd.gob.es/dctm/revista-deeducacion/articulosre336/re33619.pdf?documentId=0901e72b81248 660

Cha, S. E., Jun, S. J., Kwon, D. Y., Kim, H. S., Kim, S. B., Kim J. M., ... Lee, W. G. (2011). Measuring achievement of ICT competency for students in Korea. Computers \& Education, 56, 990-1002. doi:10.1016/j.compedu.2010.11.003

Chien, YH., y Chu, PY. (2018). The different learning outcomes of high school and college students on a 3D-printing STEAM engineering design curriculum. International Journal of Science and Mathematics Education, 16(6), 1047-1064. doi:10.1007/s10763-017-9832-4

Calabrese Barton, A. M. (2012). Citizen(s') science. A response to "The future of citizen science". Democracy \& Education, 20(2), 1-4. Recuperado de 
https://democracyeducationjournal.org/cgi/viewcontent.cgi?article= 1044\&context $=$ home

Caleon, I. S., y Subramaniam, R. (2008). Attitudes towards science of intellectually gifted and mainstream upper primary students in Singapore. Journal of Research in Science Teaching, 45(8), 940-954. doi:10.1002/tea.20250

Campanario, J. M., y Moya, A. (1999). ¿Cómo enseñar ciencias? Principales tendencias y propuestas. Enseñanza de las Ciencias, 17(2), 179-192. Recuperado de https://www.raco.cat/index.php/Ensenanza/article/view/21572/21 406

Cañal. P. (2007). La investigación escolar, hoy. Alambique. Didáctica de las Ciencias Experimentales, 52, 9-19. Recuperado de http://www.grao.com/es/producto/la-investigacion-escolar-hoy

Capraro, R. M., Capraro, M. M., y Morgan, J. R. (Eds.). (2013). STEM ProjectBased Learning. An integrated Science, Technology, Engineering, and Mathematics (STEM) approach (2nd ed.). Róterdam, Países Bajos: Sense.

Carrascosa Alís, J., y Gil Pérez, D. (1985). La "metodología de la superficialitat" i l'aprentatge de les ciències. Enseñanza de las Ciencias, 3(2), 113-120. Recuperado de https://ddd.uab.cat/pub/edlc/edlc_a1985v3n2/edlc_a1985v3n2p113 .pdf

Chesky, N. Z., y Wolfmeyer, M. R. (2015). Philosophy of STEM education: a critical investigation. Nueva York, NY: Palgrave Macmillan.

Chevallard, I. (1985). La transposition didactique: du savoir savant au savoir enseigné. Grenoble, Francia: La Pensée Sauvage.

Chubin, D. E., Porter, A. L., Rossini, F. A., y Conolly, T. (Eds.). (1986). Interdisciplinary analysis and research. Theory and practice of problem-focused research and development: selected readings. Mt. Airy, MD: Lomond.

Chomsky, N. (1965). Aspects of the theory of syntax. Cambridge, Massachusetts: The M.I.T. Press. 
Clough, M. P., Olson, J. K., y Niederhauser, D. S. (Eds.). (2013). The nature of technology: implications for learning and teaching. Róterdam, Países Bajos: Sense.

Coll, C. (2007). Las competencias en la educación escolar: algo más que una moda y mucho menos que un remedio. Revista Aula de Innovación Educativa, 161, 34-39. Recuperado de http://aula.grao.com/revistas/aula/161-lengua-y-expresionplastica/las-competencias-en-la-educacion-escolar-algo-mas-que-unamoda-y-mucho-menos-que-un-remedio

Collins, A. (1992). Toward a design science of education. En E. Scanlon y T. O'Shea (Eds.), New directions in educational technology (pp. 15-22). Berlín, Alemania: Springer-Verlag.

Confederación de Sociedades Científicas de España. (2011). Informe ENCIENDE. Enseñanza de las ciencias en la didáctica escolar para edades tempranas en España. Madrid, España: Autor.

Connor, A. M., Karmokar, S., y Whittington, C. (2015). From STEM to STEAM: strategies for enhancing engineering \& technology education. International Journal of Engineering Pedagogies, 5(2), 37-47. doi:10.3991/ijep.v5i2.4458

Cools, S., Conradie, P., Ciocci, M-C., y Saldien, J. (2018). The Diorama Project: development of a tangible medium to foster STEAM education using storytelling and electronics. En O. Mealha, M. Diviniti y M. Rehm (Eds.), Proceedings of the 2nd International Conference on Smart Learning Ecosystems and Regional Development (pp. 169-178). Aveiro, Portugal: Springer.

Couso, D., y Adúriz-Bravo, A. (2016). La enseñanza del diseño de unidades didácticas competenciales en la profesionalización del profesorado de ciencias. En G. A. Perafán Echeverri, E. Badillo Jiménez y A. AdúrizBravo (Coords.), Conocimiento y emociones del profesorado. Contribuciones para su desarrollo e implicaciones didácticas (pp. 265-283). Bogotá, Colombia: Aula de Humanidades.

Creswell, J. W., y Creswell, J. D. (2018). Research design: qualitative, quantitative, and mixed methods approaches (5th ed.). Los Ángeles, CA: SAGE. 
Creswell, J. W., y Guetterman, T. C. (2019). Educational research: planning, conducting, and evaluating quantitative and qualitative research (6th ed.). Nueva York, NY: Pearson.

Creswell, J. W., y Plano Clark, V. L. (2018). Designing and conducting mixed methods research (3th ed.). Los Ángeles, CA: SAGE.

Dabrowski, M., y Wiśniewski, J. (2011). Translating key competences into the school curriculum: lessons from the polish experience. European Journal of Education, 46(3), 323-334. doi:10.1111/j.1465-3435.2011.01483.x

Dahncke, H., Duit, R., Gilbert, J., Östman, L., Psillos, D., y Pushkin, D. B. (2001). Science education versus science in the academy: questionsdiscussion-perspectives. En H. Behrendt, H. Dahncke, R. Duit, W. Gräber, M. Komorek, A. Kross y P. Reiska (Eds.), Research in science education. Past, present, and future (pp. 43-48). Dordrecht, Países Bajos: Kluwer Academic.

De Ketele, J. M. (2008). Enfoque socio-histórico de las competencias en la enseñanza. Profesorado. Revista de Currículum y Formación del Profesorado, 12(3), 1-12. Recuperado de https://recyt.fecyt.es/index.php/profesorado/article/view/41514/23 609

DeBoer, G. E. (1991). A bistory of ideas in science education: implications for practice. Nueva York, NY: Teachers College Press.

DECRETO 26/2016, de 21 de Julio, por el que se establece el currículo y se regula la implantación, evaluación y desarrollo de la Educación Primaria en la Comunidad de Castilla y León. Boletín Oficial de Castilla y León. Valladolid, 25 de julio de 2016, núm. 142, pp. 34184-34746.

DeJarnette, N. K. (2018). Implementing STEAM in the early childhood classroom. European Journal of STEM Education, 3(3), 1-9. doi:10.20897/ejsteme/3878

Delors, J. (1996). La educación encierra un tesoro. Informe a la UNESCO de la comisión internacional sobre la educación para el siglo XXI. Madrid, España: Santillana.

Denessen, E., Vos, N., Hasselman, F., y Louws, M. (2015). The relationship between primary school teacher and student attitudes towards science 
and technology. Education Research International, 2015, 1-7. doi:10.1155/2015/534690

Dewey, J. (1929). The sources of a science of education. Nueva York, NY: Horace Liveright.

DeWitt, J., y Archer, L. (2015). Who aspires to a science career? A comparison of survey responses from primary and secondary school students. International Journal of Science Education, 37(13), 2170-2192. doi:10.1080/09500693.2015.1071899

Díaz Barriga, Á. (2013). Secuencias de aprendizaje. ¿Un problema del enfoque de competencias o un reencuentro con perspectivas didácticas? Profesorado. Revista de Currículum y Formación del Profesorado, 17(3), 11-33. Recuperado de https://recyt.fecyt.es/index.php/profesorado/article/view/41685/23 758

Dijkstra, A. B., Geijsel, F., Ledoux, G., van der Veen, I., y ten Dam, G. (2015). Effects of school quality, school citizenship policy, and student body composition on the acquisition of citizenship competences in the final year of primary education. School Effectiveness and School Improvement, 26(4), 524-553. doi:10.1080/09243453.2014.969282

Domingo Segovia, J., Gallego Ortega, J. L., García Aróstegui, I., y Rodríguez Fuentes, A. (2010). Competencias comunicativas de maestros en formación. Profesorado. Revista de Curriculum y Formación del Profesorado, 14(2), 303-323. Recuperado de https://recyt.fecyt.es/index.php/profesorado/article/view/42921/24 799

Dossey, J. A. (1992). The nature of mathematics: its role and its influence. En D. A. Grouws (Ed.), Handbook of research on mathematics teaching and learning (pp. 39-48). Reston, VA: NCTM.

Duban, N., Aydoğdu, B., y Kolsuz, S. (2018). STEAM implementations for elementary school students in Turkey. Journal of STEM Arts, Crafts, and Constructions, 3(2), 41-58. Recuperado de https://scholarworks.uni.edu/cgi/viewcontent.cgi?article=1030\&cont ext=journal-stem-arts 
Duit, R. (2006). La investigación sobre enseñanza de las ciencias. Un requisito imprescindible para mejorar la práctica educativa. Revista Mexicana de Investigación Educativa, 11(30), 741-770. Recuperado de http://comie.org.mx/revista/v2018/rmie/index.php/nrmie/article/v iew $/ 715 / 715$

Duit, R., Gropengießer, H., y Kattmann, U. (2005). Towards science education research that is relevant for improving practice: the model of educational reconstruction. En H. E. Fischer (Ed.), Developing standards in research on science education (pp. 1-9). Londres, Inglaterra: Taylor \& Francis.

Duschl, R. A. (1990). Restructuring science education. The importance of theories and their development. Nueva York, NY: Teacher College Press.

Edwards-Schachter, M., y Greca, I. M. (2017). Responsible research and innovation: an opportunity to reframing science (and technological) education? Trabajo presentado en la ESERA 2017 Conference, Dublín, Irlanda.

Engelman, S., Magerko, B., McKlin, T., Miller, M., Edwards, D., y Freeman, J. (2017). Creativity in authentic STEAM education with Earsketch. The SIGCSE 2017 Technical Symposium, Seattle, 183-188. doi:10.1145/3017680.3017763

England, J. M. (1976). Dr. Bush writes a report: "science-the endless frontier". Science, 191(4222), 41-47. doi:10.1126/science.191.4222.41

English, L. D., y King, D. T. (2015). STEM learning through engineering design: fourth-grade students' investigations in aerospace. International Journal of STEM Education, 2(14), 1-18. doi:10.1186/s40594-015-0027-7

Erduran, S. (2014). Beyond nature of science: the case for reconceptualising 'science' for science education. Science Education International, 25(1), 93$111 . \quad$ Recuperado de http://www.icaseonline.net/sei/march2014/p11.pdf

Ernest, P. (1992). The nature of mathematics: towards a social constructivist account. Science \& Education, 1(1), 89-100. doi:10.1007/BF00430212

Ernest, P. (1993). Constructivism, the psychology of learning, and the nature of mathematics: some critical issues. Science \& Education, 2(1), 87-93. doi:10.1007/BF00486663 
España, E., Cabello, A., y Blanco, A. (2014). La competencia en alimentación. Un marco de referencia para la educación obligatoria. Enseñanza de las Ciencias, 32(3), 611-629. doi:10.5565/rev/ensciencias.1080

European Commission. (2007). Science education now: a renewed pedagogy for the future of Europe. Bruselas, Bélgica: European Communities.

European Commission. (2015). Science education for responsible citizenship. Bruselas, Bélgica: European Union.

European Commission. (2017). Report on the results of the stakeholder consultation. Recuperado de

https://ec.europa.eu/education/sites/education/files/2017-keycompetences-consultation-review_en.pdf

European Parliament and Council. (2006). Recommendation of the European Parliament and of the Council of 18 december 2006 on key competences for lifelong learning. Official Journal of the European Union, 49(L394), 10-18. Recuperado de http://eur-lex.europa.eu/legalcontent/EN/TXT/?uri=uriserv:OJ.L_.2006.394.01.0010.01.ENG\&t oc $=$ OJ:L:2006:394:TOC

Eurydice. (2002). Key competencies. A developing concept in general compulsory education. Bruselas, Bélgica: Eurydice European Unit.

Feher, E., y Rice Meyer, K. (1992). Children's conceptions of color. Journal of Research in Science Teaching, 29(5), 505-520. doi: 10.1002/tea.3660290506

Fernández Cano, A. (2001). Valoración del impacto de la investigación educativa sobra la práctica docente. Revista de Educación, 324, 155-170. Recuperado de http://www.educacionyfp.gob.es/dam/jcr:73ed99ba74f7-4189-a7fc-a42ae8f4f12f/re3241109310-pdf.pdf

Fernández March, A. (2006). Metodologías activas para la formación de competencias. Educatio Siglo XXI, 24, 35-56. Recuperado de https://revistas.um.es/educatio/article/view/152/135

Fensham, P. J. (2001). Science content as problematic: issues for research. En H. Behrendt, H. Dahncke, R. Duit, W. Gräber, M. Komorek, A. Kross y P. Reiska (Eds.), Research in science education. Past, present, and future (pp. 27-41). Dordrecht, Países Bajos: Kluwer Academic. 
Galison, P. (1997). Image and logic: a material culture of microphysics. Chicago, IL: The University of Chicago Press.

Gallagher, J. J. (1971). A broader base for science education. Science Education, 55(3), 329-338. doi:10.1002/sce.3730550312

Gallardo-Gil, M., Fernández-Navas, M., Sepúlveda-Ruiz, M. P., Serván, M. J., Yus, R., y Barquín, J. (2010). PISA y la competencia científica: un análisis de las pruebas de PISA en el Área de Ciencias. RELIEVE, 16(2), 1-17. Recuperado de https://www.uv.es/RELIEVE/v16n2/RELIEVEv16n2_6.htm

Garibay, J. C. (2015). STEM students' social agency and views on working for social change: are STEM disciplines developing socially and civically responsible students? Journal of Research in Science Teaching, 52(5), 610632. doi:10.1002/tea.21203

George, R. (2006). A cross-domain analysis of change in students' attitudes toward science and attitudes about the utility of science. International Journal of Science Education, 28(6), 571-589. doi:10.1080/09500690500338755

Gil Cantero, F., y Reyero, D. (2014). La prioridad de la filosofía de la educación sobre las disciplinas empíricas en la investigación educativa. Revista Española de Pedagogía, LXXII(258), 263-280. Recuperado de https://revistadepedagogia.org/wp-content/uploads/2014/06/25803.pdf

Gil Pérez, D. (1986). La metodología científica y la enseñanza de las ciencias. Unas relaciones controvertidas. Enseñanza de las Ciencias, 4(2), 111-121. Recuperado de https://ddd.uab.cat/pub/edlc/edlc_a1986v4n2/edlc_a1986v4n2p111 .pdf

Gil Pérez, D., y Vilches, A. (2006). ¿Cómo puede contribuir el proyecto PISA a la mejora de la enseñanza de las ciencias (y de otras áreas de conocimiento)? Revista de Educación, $N^{o}$ Extraordinario, 295-311. Recuperado de http://www.educacionyfp.gob.es/dam/jcr:86efe16497dd-41c9-851a-6ddb548ceb76/re200617-pdf.pdf

Gimeno Sacristán, J. (Comp.). (2008). Educar por competencias, ¿qué hay de nuevo? Madrid, España: Morata. 
Gimeno Sacristán, J. (2013). El curriculum: una reflexión sobre la práctica (10th ed.). Madrid, España: Morata.

González Aguado, M. E. (2017). Situaciones problema: punto de partida para el desarrollo de la competencia científica. Alambique. Didáctica de las Ciencias Experimentales, 88, 79-82. Recuperado de https://www.grao.com/es/producto/recursos-para-el-aulasituaciones-problema-punto-de-partida-para-el-desarrollo-de-lacompetencia-cientifica

Gordon, J., Halasz, G., Krawczyk, M., Leney, T., Michel, A., Pepper, D., ... Wiśniewski, J. (2009). Key competences in Europe: opening doors for lifelong learners across the school curriculum and teacher education. Varsovia, Polonia: CASE.

Gough, A. (2015). STEM policy and science education: scientistic curriculum and sociopolitical silences. Cultural Studies of Science Education, 10(2), 445458. doi:10.1007/s11422-014-9590-3

Gough, D., Oliver, S., y Thomas, J. (2013). Learning from research: systematic reviews for informing policy decisions: a quick guide. A paper for the Alliance for Useful Evidence. Londres, Inglaterra: Nesta.

Greca, I. M. (2018). La enseñanza STEAM en la Educación Primaria. En I. M. Greca y J. Á. Meneses Villagrá (Eds.), Proyectos STEAM para la Educación Primaria. Fundamentos y aplicaciones prácticas (pp. 19-40). Madrid, España: Dextra.

Greca, I. M., y Pereira de Ataíde, A. R. (2019). Theorems-in-action for problem-solving and epistemic views on the relationship between physics and mathematics among preservice physics teachers. En G. Pospiech, M. Michelini y B-S. Eylon (Eds.), Mathematics in physics education (pp. 153-173). Cham, Suiza: Springer.

Greca, I. M., Seoane, E., y Arriassecq, I. (2014). Epistemological issues concerning computer simulations in science and their implications for science education. Science \& Education, 23(4), 897-921. doi:10.1007/s11191-013-9673-7

Gresnigt, R., Taconis, R., van Keulen, H., Gravemeijer, K., y Baartman, L. (2014). Promoting science and technology in primary education: a 
review of integrated curricula. Studies in Science Education, 50(1), 47-84. doi:10.1080/03057267.2013.877694

Guarro Pallás, A. (2008). Competencias básicas: currículum integrado y aprendizaje cooperativo. Investigación en la Escuela, 66, 29-42. Recuperado de http://www.investigacionenlaescuela.es/articulos/66/R-66_2.pdf

Guesne, E. (1985). Light. En R. Driver, E. Guesne y A. Tiberghien (Eds.), Children's ideas in science (pp. 10-32). Philadelphia, PA: Open University Press.

Guisasola, J., Zubimendi, J. L., Almudí, J. M., y Cebeiro, M. (2008). Dificultades persistentes en el aprendizaje de la electricidad: estrategias de razonamiento de los estudiantes al explicar fenómenos de carga eléctrica. Enseñanza de las Ciencias, 26(2), 177-192. Recuperado de https://ddd.uab.cat/pub/edlc/02124521v26n2/02124521v26n2p177. pdf

Gupta, A., Elby, A., y Conlin, L. D. (2014). How substance-based ontologies for gravity can be productive: a case study. Physical Review Physics Education Research, 10(1). doi:10.1103/PhysRevSTPER.10.010113

Hacieminoglu, E. (2016). Elementary school students' attitude toward science and related variables. International Journal of Environmental \& Science Education, 11(2), 35-52. doi:10.12973/ijese.2016.288a

Hacking, I. (1983). Representing and intervening: introductory topics in the philosophy of natural science. Cambridge, Ingleterra: Cambridge University Press.

Haraway,

D.

Modest_Witness@Second

Millennium.FemaleMan_Meets_OncoMouse: feminist and technoscience. Nueva York, NY: Routledge.

Harding, S. (1991). Whose science? Whose knowledge?: Thinking from women's lives. Ithaca, NY: Cornell University Press

Harlen, W. (Ed.). (2015). Working with big ideas of science education. Trieste, Italia: IAP.

Hernández-Bravo, J. R., Cardona-Moltó, M. C., y Hernández-Bravo, J. A. (2016). The effects of an individualised ICT-based music education programme on primary school students' musical competence and 
grades. Music Education Research, 18(2), 176-194. doi:10.1080/14613808.2015.1049255

Herschbach, D. R. (2011). The STEM Initiative: constraints and challenges. Journal of STEM Teacher Education, 48(1), 96-122. Recuperado de https://ir.library.illinoisstate.edu/cgi/viewcontent.cgi?article $=1051 \& c$ ontext $=$ jste

Hierrezuelo Moreno, J., Bullejos de la Higuera, J., Carmona García-Galán, A., Molina González, E., Montero Moreno, A., Mozas Arroyo, T., ... del Valle Núñez, V. (1995). Electricidad. En J. Hierrezuelo Moreno (Coord.), Ciencias de la Naturaleza (Vol. III), (pp. 7-106). Madrid, España: MEC y EDELVIVES.

Hoachlander, G., y Yanofsky, D. (2011). Making STEM real. Educational Leadership, 68(6), 60-65. Recuperado de http://www.connectedcalifornia.org/about/www.connectedcalifornia .org/direct/files/MakingSTEMReal-EdLeadershipMagazine2011.pdf

Hodson, D. (2006). Why we should prioritize learning about science. Canadian Journal of Science, Mathematics and Technology Education, 6(3), 293-311. doi:10.1080/14926150609556703

Hoeg, D., y Bencze, L. (2017). Rising against a gathering storm: a biopolitical analysis of citizenship in STEM policy. Cultural Studies of Science Education, 12(4), 843-861. doi:10.1007/s11422-017-9838-9

Houkes, W. (2009). The nature of technological knowledge. En A. Meijers (Ed.), Philosophy of technology and engineering sciences (pp. 309-350). Ámsterdam, Países Bajos: North Holland.

Hughes, T. P. (2012). The evolution of large technological systems. En W. E. Biker, T. P. Hughes y T. J. Pinch (Eds.), The social construction of technological systems: new directions in the sociology and history of technology (anniversary edition) (pp. 45-77). Cambridge, MA: MIT Press.

Hurd, P. D. (1975). Science, technology, and society: new goals for interdisciplinary science teaching. The Science Teacher, 42(2), 27-30. Recuperado de https://www.jstor.org/stable/24126011\%0A

Iglesias Albarrán, L. M. (2017). Demostraciones del Teorema de Pitágoras con goma EVA. STEAM en el aula de Matemáticas. Épsilon - Revista de 
Educación Matemática, 97, 57-64. Recuperado de https://thales.cica.es/epsilon/sites/thales.cica.es.epsilon/files/epsilo n97_4.pdf

Irzik, G., y Nola, R. (2011). A family resemblance approach to the nature of science for science education. Science \& Education, 20(7-8), 591-607. doi:10.1007/s11191-010-9293-4

Irzik, G., y Nola, R. (2014). New directions for nature of science research. En M. R. Matthews (Ed.), International handbook of research in history, philosopby and science teaching (pp. 999-1021). Dordrecht, Países Bajos: Springer.

Izquierdo Aymerich, M. (2012). El desarrollo de competencias en la clase de ciencias y matemáticas. En E. Badillo, L. García, A. Marbà y M. Briceño (Eds.), El desarrollo de competencias en la clase de ciencias y matemáticas (pp. 1315). Mérida, Venezuela: Universidad de Los Andes.

Jantsch, E. (1972). Towards interdisciplinarity and transdisciplinarity in education and innovation. En L. Apostel, G. Berger, A. Briggs y G. Michaud (Eds.), Interdisciplinarity: problems of teaching and research in universities (pp. 97-121). París, Francia: OECD.

Jarvis, T., y Pell, A. (2005). Factors influencing elementary school children's attitudes toward science before, during, and after a visit to the UK National Space Centre. Journal of Research in Science Teaching, 42(1), 53-83. doi:10.1002/tea.20045

Jeong, S., y Kim, H. (2015). The effect of a climate change monitoring program on students' knowledge and perceptions of STEAM education in Korea. Eurasia Journal of Mathematics, Science \& Technology Education, 11(6), 1321-1338. doi:10.12973/eurasia.2015.1390a

Jiménez Iglesias, M., Müller, J., Ruiz-Mallén, I., Kim, E., Cripps, E., Heras, M., ... Vizzini, C. (2018). Gender and innovation in STE(A)M education. Recuperado del sitio de Internet de Scientix: http://www.scientix.eu/documents/10137/752677/ScientixSPNE12-Gender-Innovation-STEAM_Final.pdf/e907b19e-08634502-a396-9ad6a5184be0

de Juanas Oliva, A., Ezquerra Martínez, A., Martín del Pozo, R., y Pesquero Franco, E. (2012). Competencias docentes para el desarrollo de las competencias básicas de los alumnos. Investigación en la Escuela, 78, 43- 
54.

Recuperado

de

http://www.investigacionenlaescuela.es/articulos/78/R78.4.pdf

Junta de Castilla y León. (2018). Evaluación fin de etapa $6^{\circ}$ de Primaria 2017-2018. Recuperado de https://www.educa.jcyl.es/es/temas/calidadevaluacion/evaluaciones-regionales-educacion/evaluaciones-fin-etapa

Karageorgiou, Z., Mavrommati, E., y Fotaris, P. (2019). Escape room design as a game-based learning process for STEAM education. Proceedings of the 13th European Conference on Games Based Learning ECGBL 2019, Odense, 378-385.

Kaya, E., y Erduran, S. (2016). From FRA to RFN, or how the family resemblance approach can be transformed for science curriculum analysis on nature of science. Science \& Education, 25(9-10), 1115-1133. doi:10.1007/s11191-016-9861-3

Kelley, T. R., y Knowles, J. G. (2016). A conceptual framework for integrated STEM education. International Journal of STEM Education, 3(11), 1-11. doi:10.1186/s40594-016-0046-z

Kelly, A. E., Lesh, R. A., y Baek, J. Y. (Eds.). (2008). Handbook of design research methods in education. Innovations in science, technology, engineering, and mathematics learning and teaching. Nueva York, NY: Routledge.

Kennedy, M. M. (1997). The connection between research and practice. Educational Researcher, 26(7), 4-12. doi:10.3102/0013189x026007004

Kezar, A., Gehrke, S., y Bernstein-Sierra, S. (2017). Designing for success in STEM communities of practice: philosophy and personal interactions. The Review of Higher Education, 40(2), 217-244. doi:10.1353/rhe.2017.0002

Kim, B., y Bastani, R. (2017). Students as game designers: transdisciplinary approach to STEAM education. Alberta Science Education Journal, 45(1), 45-52.

Recuperado

de https://sc.teachers.ab.ca/SiteCollectionDocuments/ASEJVol45No1 November2017.pdf

Kim, D., y Bolger, M. (2017). Analysis of Korean elementary pre-service teachers' changing attitudes about integrated STEAM pedagogy 
through developing lesson plans. International Journal of Science and Mathematics Education, 15(4), 587-605. doi:10.1007/s10763-015-9709-3

Kim, D-H., Ko, D. G., Han, M-J., y Hong, S-H. (2014). The effects of science lessons applying STEAM education program on the creativity and interest levels of elementary students. Journal of the Korean Association for Science Education, 34(1). doi:10.14697/jkase.2014.34.1.1.00043

Kim, H., y Chae, D-H. (2016). The development and application of a STEAM programbased on traditional Korean culture. Eurasia Journal of Mathematics, Science \& Technology Education, 12(7), 1925-1936. doi:10.12973/eurasia.2016.1539a

Kim, J., Kim, Y., y Park, N. (2014). Result of implementing STEAM program and analysis of effectiveness for Smart Grid's education. En J. J. Park, H. Adeli, N. Park y I. Woungang (Eds.), Mobile, ubiquitous, and intelligent computing (pp. 529-534). Heidelberg, Alemania: Springer.

Kinnear, V. (2013). Young children's statistical reasoning: a tale of two contexts (Tesis doctoral). Recuperada de https://eprints.qut.edu.au/63496/1/Virginia_KINNEAR_Thesis.pdf

Klein, J. T. (1990). Interdisciplinarity: history, theory, and practice. Detroit, MI: Wayne State University Press.

Kroes, P. (2012). Technical artefacts: creations of mind and matter. A philosophy of engineering design. Dordrecht, Países Bajos: Springer.

Kuhn, T. S. (1962). The structure of scientific revolutions. Chicago, IL: The University of Chicago Press.

Lakatos, I. (1970). Falsification and the methodology of scientific research programmes. En I. Lakatos y A. Musgrave (Eds.), Criticism and the growth of knowledge (pp. 91-196). Londres, Inglaterra: Criticism and the growth of knowledge.

Land, M. H. (2013). Full STEAM ahead: the benefits of integrating the arts into STEM. Procedia Computer Science, 20, 547-552. doi:10.1016/j.procs.2013.09.317

Latour, B. (1987). Science in action: how to follow scientists and engineers through society. Cambridge, MA: Harvard University Press. 
Laudan, L. (1977). Progress and its problems. Berkeley, CA: University of California Press.

Laudan, L. (1984). Science and values: the aims of science and their role in scientific debate. Berkeley, CA: University of California Press.

Le Boterf, G. (1998). L'ingénierie des compétences. París, Francia: Éditions d'Organisation.

Lederman, N. G. (1992). Students' and teachers' conceptions of the nature of science: a review of the research. Journal of Research in Science Teaching, 29(4), 331-359. doi:10.1002/tea.3660290404

Lederman, N. G. (2010). Nature of science: past, present, and future. En S. K. Abell y N. G. Lederman (Eds.), Handbook of research on science education (pp. 831-879). Nueva York, NY: Routledge.

Lerman, S. (1990). Alternative perspectives of the nature of mathematics and their influence on the teaching of mathematics. British Educational Research Journal, 16(1), 53-61. doi:10.1080/0141192900160105

Letina, A. (2016). Effectiveness of inquiry-based science and social studies teaching in the development of students' scientific competence. Croatian Journal of Education, 18(3), 665-696. doi:10.15516/cje.v18i3.1735

Levinson, R. (2018). Introducing socio-scientific inquiry-based learning (SSIBL). School Science Review, 100(371), 31-35. Recuperado de https://www.ase.org.uk/system/files/SSR_December_2018_031035_Levinson_0.pdf

LEY 14/1970, de 4 de agosto, General de Educación y Financiamiento de la Reforma Educativa. Boletin Oficial del Estado. Madrid, 6 de agosto de 1970, núm. 187, pp. 12525-12546.

LEY ORGÁNICA 1/1990, de 3 de octubre, de Ordenación General del Sistema Educativo. Boletín Oficial del Estado. Madrid, 4 de octubre de 1990, núm. 238, pp. 28927-28942.

Ley Orgánica 2/2006, de 3 de mayo, de Educación. Boletín Oficial del Estado. Madrid, 4 de mayo de 2006, núm. 106, pp. 17158-17207. 
Ley Orgánica 8/2013, de 9 de diciembre, para la mejora de la calidad educativa. Boletín Oficial del Estado. Madrid, 10 de diciembre de 2013, núm. 295, pp. 97858-97921.

LEY ORGÁNICA 10/2002, de 23 de diciembre, de Calidad de la Educación. Boletin Oficial del Estado. Madrid, 24 de diciembre de 2002, núm. 307, pp. 45188-45220.

Liberati, A., Altman, D. G., Tetzlaff, J., Mulrow, C., Gøtzsche, P. C., Ioannidis, J. P. A., ... Moher, D. (2009). The PRISMA statement for reporting systematic reviews and meta-analyses of studies that evaluate health care interventions: explanation and elaboration. PLoS Med, 6(7), 1-28. doi:10.1371/journal.pmed.1000100

Liliawai, W., Rusnayati, H., Purwanto, y Aristania, G. (2018). Implementation of STEAM education to improve mastery concept. IOP Conference Series: Materials Science and Engineering, 288(1), 1-6. doi:10.1088/1757899X/288/1/012148

López Gómez, E. (2016). En torno al concepto de competencia: un análisis de fuentes. Profesorado. Revista de Currículum y Formación del Profesorado, 20(1), 311-322. Recuperado de https://recyt.fecyt.es/index.php/profesorado/article/view/49881/30 506

Lozano-Martínez, J., y Alcaraz-García, S. (2011). Software educativo para la enseñanza de competencias emocionales en el alumnado con trastornos del espectro autista. Educación XX1, 14(2), 189-212. doi:10.5944/educxx1.14.2.250

Lundgren, U. P. (1991). Between education and schooling: outlines of a diachronic curriculum theory. Victoria, Australia: Deakin University.

Madden, M. E., Baxter, M., Beauchamp, H., Bouchard, K., Habermas, D., Huff, M., ... Plague, G. (2013). Rethinking STEM education: an interdisciplinary STEAM curriculum. Procedia Computer Science, 20, 541546. doi:10.1016/j.procs.2013.09.316

Maltese, A. V., y Tai, R. H. (2010). Eyeballs in the fridge: sources of early interest in science. International Journal of Science Education, 32(5), 669-685. doi:10.1080/09500690902792385 
Marbà-Tallada, A., y Márquez Bargalló, C. (2010). ¿Qué opinan los estudiantes de las clases de ciencias? Un estudio transversal de sexto de primaria a cuarto de ESO. Enseñanza de las Ciencias, 28(1), 19-30. Recuperado de https://ddd.uab.cat/pub/edlc/02124521v28n1/02124521v28n1p19.p df

Marcus, A. (1996). The inventor of the mustache cup: James Emerson and populist technology, 1870-1900. En H. Cravens, A. I. Marcus y D. M. Katzman (Eds.), Technical knowledge in American culture: science, technology, and medicine since the early 1800s (pp. 93-109). Tuscaloosa, AL: University of Alabama Press.

Martin, M. O., Mullis, I. V. S., Foy, P., y Hooper, M. (2016). TIMSS 2015 international results in science. Chestnut Hill, MA: TIMSS \& PIRLS International Study Center, Lynch School of Education, Boston College e IEA.

Martin, M. O., Mullis, I. V. S., Foy, P., y Stanco, G. M. (2012). TIMSS 2011 international results in science. Chestnut Hill, MA: TIMSS \& PIRLS International Study Center, Lynch School of Education, Boston College e IEA.

Martin-Hansen, L. (2002). Defining inquiry: exploring the many types of inquiry in the science classroom. The Science Teacher, 69(2), 34-37. Recuperado de https://www.jstor.org/stable/24154746

Martín-Páez, T., Aguilera, D., Perales-Palacios, F. J., y Vílchez-González, J. M. (2019). What are we talking about when we talk about STEM education? A review of literature. Science Education, 103(4), 799-822. doi:10.1002/sce.21522

Martinand, J. L. (1986). Connaitre et transformer la matière. Berna, Suiza: Peter Lang.

Martinand, J. L. (1988). Cuestiones actuales de la didáctica de las ciencias físicas en Francia: observaciones comparativas. Enseñanza de las Ciencias, 6(1), 47-53. Recuperado http://www.raco.cat/index.php/Ensenanza/article/view/51044/929 50 
Martínez Clares, P., y Echeverría Samanes, B. (2009). Revista de Investigación Educativa, 27(1), 125-147. Recuperado de https://revistas.um.es/rie/article/view/94331/102961

Massot Lafon, I., Dorio Alcaraz, I., y Sabariego Puig, M. (2004). Estrategias de recogida y análisis de la información. En R. Bisquerra Alzina (Coord.), Metodología de la investigación educativa (pp. 329-366). Madrid, España: La Muralla.

Matthews, M. R. (2012). Changing the focus: from nature of science (NOS) to features of science (FOS). En M. S. Khine (Ed.), Advances in nature of science research: concepts and methodologies (pp. 3-26). Dordrecht, Países Bajos: Springer.

Mayós, C. (2003). Evaluación de las competencias básicas en Cataluña. Alambique. Didáctica de las Ciencias Experimentales, 37. Recuperado de http://alambique.grao.com/revistas/alambique/37-la-evaluacionexterna-de-los-aprendizajes/evaluacion-de-las-competencias-basicasen-cataluna

Méheut, M., y Psillos, D. (2004). Teaching-learning sequences: aims and tools for science education research. International Journal of Science Education, 26(5), 515-535. doi:10.1080/09500690310001614762

Meijers, A. (2009). General introduction. En A. Meijers (Ed.), Philosophy of technology and engineering sciences (pp. 1-19). Ámsterdam, Países Bajos: North Holland.

Méndez-Giménez, A., Sierra-Arizmendiarrieta, B., y Mañana-Rodríguez, J. (2013). Percepciones y creencias de los docentes de Primaria del Principado de Asturias sobre las competencias básicas. Revista de Educación, 362, 737-761. doi:10.4438/1988-592X-RE-2013-362-248

Mertens, L. (1996). Competencia laboral: sistemas, surgimiento y modelos. Montevideo, Uruguay: Cinterfor/OIT.

Merton, R. K. (1973). The normative structure of science. En R. K. Merton (Ed.), The sociology of science: theoretical and empirical investigations (pp. 267278). Chicago, IL: The University of Chicago Press. 
McBride, J. W., y Silverman, F. L. (1991). Integrating elementary/middle school science and mathematics. School Science and Mathematics, 91(7), 285-292. doi:10.1111/j.1949-8594.1991.tb12102.x

McClelland, D. C. (1973). Testing for competence rather than for "intelligence". American Psychologist, 28(1), 1-14. doi:10.1037/h0034092

McComas, W. F. (Ed.). (1998). The nature of science in science education. Rationales and strategies. Dordrecht, Países Bajos: Kluwer Academic.

McComas, W. F. (Ed.). (2014). The language of science education: an expanded glossary of key terms and concepts in science teaching and learning. Róterdam, Países Bajos: Sense.

McIntyre, D. (2005). Bridging the gap between research and practice. Cambridge Journal of Education, 35(3), 357-382. doi:10.1080/03057640500319065

McNeil, L. M. (2000). Contradictions of school reform: educational costs of standardized testing. Nueva York, NY: Routledge.

Michael, J. (2006). Where's the evidence that active learning works? Advances in Physiology Education, 30(4), 159-167. doi:10.1152/advan.00053.2006

Ministerio de Educación. (2010). Evaluación general de diagnóstico 2009. Educación Primaria. Cuarto curso. Informe de resultados. Madrid, España: Autor.

Ministerio de Educación. (2011). Evaluación general de diagnóstico 2010. Educación Secundaria Obligatoria. Segundo curso. Informe de resultados. Madrid, España: Autor.

Ministerio de Educación, Cultura y Deporte. (2013a). PIRLS-TIMS 2011. Estudio internacional de progreso en comprensión lectora, matemáticas y ciencias. IEA. Volumen I. Informe español. Madrid, España: Autor.

Ministerio de Educación, Cultura y Deporte. (2013b). PIRLS-TIMS 2011. Estudio internacional de progreso en comprensión lectora, matemáticas y ciencias. IEA. Volumen II. Informe español. Análisis Secundario. Madrid, España: Autor.

Ministerio de Educación, Cultura y Deporte. (2014). PIS A 2012. Programa para la evaluación internacional de los alumnos. Informe español. Resultados y contexto. Madrid, España: Autor. 
Ministerio de Educación, Cultura y Deporte. (2016a). TIMSS 2015. Estudio internacional de tendencias en matemáticas y ciencias. IE A. Informe español: resultados y contexto. Madrid, España: Autor.

Ministerio de Educación, Cultura y Deporte. (2016b). PIS A 2015. Programa para la evaluación internacional de los alumnos. Informe español. Madrid, España: Autor.

Minner, D. D., Levy, A. J., y Century, J. (2010). Inquiry-based science instruction-What is it and does it matter? Results from a research synthesis years 1984 to 2002. Journal of Research in Science Teaching, 47(4), 474-496. doi:10.1002/tea.20347

Miralles Martínez, P., Gómez Carrasco, C. J., y Monteagudo Fernández, J. (2012). La evaluación de la competencia social y ciudadana en ciencias sociales al finalizar las etapas de primaria y secundaria. Investigación en la Escuela, 78, 19-30. Recuperado de http://www.investigacionenlaescuela.es/articulos/78/R78.2.pdf

Mitcham, C. (1994). Thinking through technology: the path between engineering and philosophy. Chicago, IL: The University of Chicago Press.

Mitcham, C., y Schatzberg, E. (2009). En A. Meijers (Ed.), Philosophy of technology and engineering sciences (pp. 27-63). Ámsterdam, Países Bajos: North Holland.

Mizell, S., y Brown, S. (2016). The current status of STEM education research 2013-2015. Journal of STEM Education, 17(4), 52-56. Recuperado de http://litee.org/jstem/index.php/JSTEM/article/view/2169/1815

Moher, D., Liberati, A., Tetzlaff, J., Altman, D. G., y The PRISMA Group. (2009). Preferred reporting items for systematic reviews and metaanalyses: The PRISMA Statement. PLoS Med, 6(7), 1-6. doi:10.1371/journal.pmed.1000097

Molina, M., Castro, E., Molina, J. L., y Castro, E. (2011). Un acercamiento a la investigación de diseño a través de los experimentos de enseñanza. Enseñanza de las Ciencias, 29(1), 75-88. doi:10.5565/REV/EC/V29N1.435

Mora, F. (2017). Neuroeducación: solo se puede aprender aquello que se ama. Madrid, España: Alianza. 
Morin, E. (1990). Introduction à la pensée complexe. París, Francia: ESF.

Mullis, I. V. S., Martin, M. O., Foy, P., y Arora, A. (2012). TIMSS 2011 international results in mathematics. Chestnut Hill, MA: TIMSS \& PIRLS International Study Center, Lynch School of Education, Boston College e IEA.

Mullis, I. V. S., Martin, M. O., Foy, M., y Drucker, K. T. (2012). PIRLS 2011 international results in reading. Chestnut Hill, MA: TIMSS \& PIRLS International Study Center, Lynch School of Education, Boston College e IEA.

Mullis, I. V. S., Martin, M. O., Foy, P., y Hooper, M. (2016). TIMSS 2015 international results in mathematics. Chestnut Hill, MA: TIMSS \& PIRLS International Study Center, Lynch School of Education, Boston College e IEA.

Mullis, I. V. S., Martin, M. O., Foy, P., y Hooper, M. (2017). PIRLS 2016 international results in reading. Chestnut Hill, MA: TIMSS \& PIRLS International Study Center, Lynch School of Education, Boston College e IEA.

Mullis, I. V. S., Martin, M. O., Kennedy, A. M., y Foy, P. (2007). PIRLS 2006 international report. Chestnut Hill, MA: TIMSS \& PIRLS International Study Center, Lynch School of Education, Boston College.

National Research Council. (2000). Inquiry and the National Science Education Standards: a guide for teaching and learning. Washington, DC: National Academy Press.

National Research Council. (2002). Scientific research in education. Washington, DC: National Academy Press.

National Research Council. (2009). Engineering in K-12 education: understanding the status and improving the prospects. Washington, DC: The National Academies Press.

National Research Council. (2011). Successful K-12 STEM education. Identifying effective approaches in science, technology, engineering, and mathematics. Washington, DC: The National Academies Press. 
National Research Council. (2012). A framework for K-12 science education: practices, crosscutting concepts, and core ideas. Washington, DC: The National Academies Press.

National Research Council. (2014). STEM Integration in K-12 education. Status, prospects, and an agenda for research. Washington, DC: The National Academies Press.

National Science Board. (1969a). Graduate education. Parameters for public policy. Recuperado del sitio de Internet de National Science Foundation: https://www.nsf.gov/nsb/publications/1969/nsb0269.pdf

National Science Board. (1969b). Toward a public policy for graduate education in the sciences. Recuperado del sitio de Internet de National Science Foundation:

https://www.nsf.gov/nsb/publications/1969/nsb0169.pdf

National Science Board. (1986). Undergraduate science, mathematics and engineering education. Recuperado del sitio de Internet de National Science Foundation:

https://www.nsf.gov/nsb/publications/1986/nsb0386.pdf

Navío, A. (2005). Propuestas conceptuales en torno a la competencia profesional. Revista de Educación, 337, 213-234. Recuperado de http://www.mecd.gob.es/dctm/revista-de-

educacion/articulosre337/re33711.pdf?documentId=0901e72b81248 $17 \mathrm{a}$

NGSS Lead States. (2013). Next generation science standards: for states, by states. Washington, DC: The National Academies Press.

Niemi, H. (2002). Active learning-a cultural change needed in teacher education and schools. Teaching and Teacher Education, 18(7), 763-780. doi:10.1016/S0742-051X(02)00042-2

Orden ECD/65/2015, de 21 de enero, por la que se describen las relaciones entre las competencias, los contenidos y los criterios de evaluación de la educación primaria, la educación secundaria obligatoria y el bachillerato. Boletín Oficial del Estado. Madrid, 29 de enero de 2015, núm. 25, pp. 6986-7003. 
Organisation for Economic Co-operation and Development. (2002). DeSeCo strategy paper. Recuperado de http://deseco.ch/bfs/deseco/en/index/02.parsys.34116.downloadLi st.87902.DownloadFile.tmp/oecddesecostrategypaperdeelsaedcericd2 0029.pdf

Organisation for Economic Co-operation and Development. (2004). Learning for tomorrow's world. First results from PIS A 2003. París, Francia: Autor.

Organisation for Economic Co-operation and Development. (2005). The definition and selection of key competencies. Executive summary. Recuperado de http://deseco.ch/bfs/deseco/en/index/02.parsys.43469.downloadLi st.2296.DownloadFile.tmp/2005.dskcexecutivesummary.en.pdf

Organisation for Economic Co-operation and Development. (2007). PISA 2006. Science competencies for tomorrow's world. Volume 1: Analysis. París, Francia: Autor.

Organisation for Economic Co-operation and Development. (2010). PISA 2009 results: what students know and can do. Students performance in reading, mathematics and science. Volume I. París, Francia: Autor.

Organisation for Economic Co-operation and Development. (2014). PISA 2012 results: what students know and can do. Student performance in mathematics, reading and science. Volume I. París, Francia: Autor.

Organisation for Economic Co-operation and Development. (2016). PISA 2015 results. Excellence and equity in education. Volume I. París, Francia: Autor.

Organisation for Economic Co-operation and Development/UNESCO Institute for Statistics. (2003). Literacy skills for the world of tomorrow. Further results from PIS A 2000. París, Francia: OECD.

Organización de las Naciones Unidas para la Educación, la Ciencia y la Cultura. (2015). Replantear la educación: ¿ Hacia un bien común mundial? París, Francia: UNESCO.

Ortiz-Revilla, J. (2016). Propuesta de una programación didáctica de Ciencias de la Naturaleza para $2^{\circ}$ de Educación Primaria a través de la metodología de indagación cientifica (Tesis de pregrado). Recuperada de http://riubu.ubu.es/bitstream/10259/4170/6/Ortiz_Revilla.pdf 
Ortiz-Revilla, J. (2018). ¿Cómo diseñar un prototipo de iluminación para mi sala de estudio? En I. M. Greca y J. Á. Meneses Villagrá (Eds.), Proyectos STEAM para la Educación Primaria. Fundamentos y aplicaciones prácticas (pp. 163-193). Madrid, España: Dextra.

Ortiz-Revilla, J., y Greca, I. M. (2017). Propuesta de una programación didáctica de Ciencias de la Naturaleza en Educación Primaria a través de la indagación científica. Enseñanza de las Ciencias, $n^{\circ}$ extraordinario, 5341-5346. Recuperado de https://ddd.uab.cat/pub/edlc/edlc_a2017/33__Propuesta_de_una_programacion_didactica_de_Ciencias_de_la_Nat uraleza.pdf

Ortiz-Revilla, J., y Greca, I. M. (2019). Desarrollo de un instrumento de evaluación competencial escolar. Trabajo presentado en el I Congreso Internacional de Innovación Docente e Investigación en Educación Superior: Un reto para las Áreas de Conocimiento, Madrid, España.

Ortiz-Revilla, J., Greca, I. M., y Adúriz-Bravo, A. (2018a). Development of physics competences in primary education through a STEAM approach. Trabajo presentado en la GIREP-MPTL 2018 International Conference, San Sebastián, España. Resumen recuperado de https://www.girep2018.com/contenidos/files/abstracts/resumen/au tor/193_abs_con_v1.pdf

Ortiz-Revilla, J., Greca, I. M., y Adúriz-Bravo, A. (2018b). In search of a notion of biological competence for primary education: A review of research articles. Trabajo presentado en la XII Conference of European Researchers in Didactics of Biology - ERIDOB 2018, Zaragoza, España. Resumen recuperado de

https://eventos.unizar.es/_files/_event/_8746/_editorFiles/file/erid ob2018/Abstracts\%20Book\%20Eridob\%202018.pdf

Ortiz-Revilla, J., Greca, I. M., y Adúriz-Bravo, A. (2018c). Presencia y caracterización de las competencias científica y matemática en estudios sobre Educación Primaria. En M. C. Papini y F. G. Sica (Eds.), Las Ciencias de la Naturaleza y la Matemática en el aula, nuevos desafios y paradigmas (pp. 259-271). Tandil, Argentina: UNICEN. 
Ortiz-Revilla, J., Greca, I. M., y Adúriz-Bravo, A. (2018d). La Educación STEAM y el desarrollo competencial en la Educación Primaria. En I. M. Greca y J. Á. Meneses Villagrá (Eds.), Proyectos STEAM para la Educación Primaria. Fundamentos y aplicaciones prácticas (pp. 41-54). Madrid, España: Dextra.

Ortiz-Revilla, J., Greca, I. M., y Adúriz-Bravo, A. (2019). The philosophy in/of integrated STEM education. En F. Seroglou y V. Koulountzos (Eds.), Re-introducing science: sculpting the image of science for education and media in its historical and philosophical background (pp. 509-517). Salónica, Grecia: Grafima.

Ortiz-Revilla, J., Greca, I. M., y Meneses Villagrá, J. Á. (2018). Mejorando la adquisición de competencias en la Educación Primaria a través de un enfoque transdisciplinario. En J. A. Pacheco Bonrostro y J. L. Cuesta Gómez (Eds.), $V$ Jornadas de Doctorandos de la Universidad de Burgos (pp. 113-124). Burgos, España: Universidad de Burgos.

Ortiz-Revilla, J., Greca, I. M., y Meneses Villagrá, J. Á. (2019). La investigación de diseño en el desarrollo de propuestas didácticas STEAM. En P. Membiela, M. I. Cebreiros y M. Vidal (Eds.), Nuevos retos en la enseñanza de las ciencias (pp. 217-222). Ourense, España: Educación Editora.

Osborne, J., y Dillon, J. (2008). Science education in Europe: critical reflections. Londres, Inglaterra: The Nuffield Foundation.

Park, B-Y., y Lee, H. (2014). Development and application of systems thinkingbased STEAM education program to improve secondary science gifted and talented students' systems thinking skill. Journal of Gifted/Talented Education, 24(3), 421-444. doi:10.9722/igte.2014.24.3.421

Pell, T., y Jarvis, T. (2001). Developing attitude to science scales for use with children of ages from five to eleven years. International Journal of Science Education, 23(8), 847-862. doi:10.1080/09500690010016111

Pepper, D. (2011). Assessing key competences across the curriculum - and Europe. European Journal of Education, 46(3), 335-353. doi:10.1111/j.1465-3435.2011.01484.x

Pérez, Á. I., y Soto, E. (2011). Luces y sombras de PISA. Sentido educativo de las evaluaciones externas. Cultura y Educación, 23(2), 171-182. doi:10.1174/113564011795944758 
Pérez Gómez, Á. I. (2008). ¿Competencias o pensamiento práctico? La construcción de los significados de representación y de acción. En J. Gimeno Sacristán (Ed.), Educar por competencias, ¿qué hay de nuevo? (59102). Madrid, España: Morata.

Pérez Manzano, A., y de Pro Bueno, A. (2018). Algunos datos sobre la visión de los niños y de las niñas sobre las ciencias y del trabajo científico. iQual. Revista de Género e Igualdad, 1, 18-31. doi:10.6018/iQual.306091

Perrenoud, P. (1997). Construire des compétences dès l'école. París, Francia: ESF.

Perrenoud, P. (1999). Dix nouvelles compétences pour enseigner. Invitation au voyage. París, Francia: ESF.

Perrenoud, P. (2009). Enfoque por competencias, ¿una respuesta al fracaso escolar? SIPS - Revista Interuniversitaria de Pedagogía Social, 16, 45-64. Recuperado de https:// recyt.fecyt.es/index.php/PSRI/article/view/36948/20514

Pešaković, D., Flogie, A., y Aberšek, B. (2014). Development and evaluation of a competence-based teaching process for science and technology education. Journal of Baltic Science Education, 13(5), 740-755. Recuperado de http://www.scientiasocialis.lt/jbse/files/pdf/vol13/740755.Pesakovic_JBSE_Vol.13_No.5.pdf

Peters-Burton, E. E. (2014). Is there a "nature of STEM"? School Science and Mathematics, 114(3), 99-101. doi:10.1111/ssm.12063

Piaget, J. (1936). La naissance de l'intelligence chez l'enfant. Neuchâtel, Suiza: Delachaux et Niestlé.

Piaget, J. (1972). The epistemology of interdisciplinary relationships. En L. Apostel, G. Berger, A. Briggs y G. Michaud (Eds.), Interdisciplinarity: problems of teaching and research in universities (pp. 127-139). París, Francia: OECD.

Pinch, T. J., y Bijker, W. E. (2012). The social construction of facts and artifacts: or how the sociology of science and the sociology of technology might benefit each other. En W. E. Biker, T. P. Hughes y T. J. Pinch (Eds.), The social construction of technological systems: new directions in the sociology and bistory of technology (anniversary edition) (pp. 11-44). Cambridge, MA: MIT Press. 
Pinos, M. (2016). Evaluación de la competencia lingüística a partir de un programa de desarrollo de competencias. Investigación en la Escuela, 90, 94-113. Recuperado de http://www.investigacionenlaescuela.es/articulos/R90/R90-6.pdf

Pirtle, Z. (2010). How the models of engineering tell the truth. En I. van de Poel \& D. E. Goldberg (Eds.), Philosophy of engineering: an emerging agenda (pp. 95-108). Dordrecht, Países Bajos: Springer.

Pleasants, J., Clough, M. P., Olson, J. K., y Miller, G. (2019). Fundamental issues regarding the nature of technology: implications for STEM education. Science \& Education, 28(3-5), 561-597. doi:10.1007/s11191019-00056-y

Pleasants, J., y Olson, J. K. (2019). What is engineering? Elaborating the nature of engineering for K-12 education. Science Education, 103(1), 145-166. doi:10.1002/sce.21483

Plomp, T. (2013). Educational design research: an introduction. En T. Plomp y N. Nieveen (Eds.), Educational design research. Part A: an introduction (pp. 10-51). Enschede, Países Bajos: SLO.

Popper, K. R. (1963). Conjectures and refutations: the growth of scientific knowledge. Londres, Inglaterra: Routledge and Kegan Paul.

Prince, M. (2004). Does active learning work? A review of the research. Journal of Engineering Education, 93(3), 223-231. doi:10.1002/j.21689830.2004.tb00809.x

de Pro Bueno, A. (2011). Aprender y enseñar con experiencias... y ahora para desarrollar competencias. Investigación en la Escuela, 74, 5-22. Recuperado de http://www.investigacionenlaescuela.es/articulos/R74/R74.1.pdf

de Pro Bueno, A., y Pérez Manzano, A. (2014). Actitudes de los alumnos de Primaria y Secundaria ante la visión dicotómica de la Ciencia. Enseñanza de las Ciencias, 32(3), 111-132. doi:10.5565/rev/ensciencias.1015

de Pro Bueno, A., y Rodríguez Moreno, J. (2010). Aprender competencias en una propuesta para la enseñanza de los circuitos eléctricos en Educación Primaria. Enseñanza de las Ciencias, 28(3), 385-404. doi:10.5565/rev/ec/v28n3.333 
Psillos, D. (2001). Science education researchers and research in transition: issues and policies. En H. Behrendt, H. Dahncke, R. Duit, W. Gräber, M. Komorek, A. Kross y P. Reiska (Eds.), Research in science education. Past, present, and future (pp. 11-16). Dordrecht, Países Bajos: Kluwer Academic.

de Puelles Benítez, M. (2000). Política y educación: cien años de historia. Revista de educación, núm. extraordinario, 7-36. Recuperado de http://www.educacionyfp.gob.es/dam/jcr:50d37356-27be-4552b09b-41145a1ff2ab/re20000208522-pdf.pdf

Puig Gutiérrez, M., y Morales Lozano, J. A. (2012). La competencia social y cívica: una aproximación a la realidad escolar. Revista Española de Pedagogía, 70(253), 441-460. Recuperado de https://revistadepedagogia.org/wp-content/uploads/2012/09/25303.pdf

Puig Gutiérrez, M., y Morales Lozano, J. A. (2015). La formación de ciudadanos: conceptualización y desarrollo de la competencia social y cívica. Educación XX1, 18(1), 259-282. doi:10.5944/educXX1.18.1.12332

Quigley, C. F., y Herro, D. (2016). "Finding the joy in the unknown": implementation of STEAM teaching practices in middle school science and math classrooms. Journal of Science Education and Technology, 25(3), 410-426. doi:10.1007/s10956-016-9602-z

Quigley, C., Herro, D., y Jamil, F. M. (2017). Developing a conceptual model of STEAM teaching practices. School Science and Mathematics, 117(1-2), 112. doi:10.1111/ssm.12201

Radder, H. (2009). Science, technology and the science-technology relationship. En A. Meijers (Ed.), Philosophy of technology and engineering sciences (pp. 65-91). Ámsterdam, Países Bajos: North Holland.

Ramaley, J. A., Olds, B. M., y Earle, J. (2005). Becoming a learning organization: new directions in science education research at the National Science Foundation. Journal of Science Education and Technology, 14(2), 173-189. doi:10.1007/s10956-005-4420-8

Ramírez García, A. (2016). Evaluación de las competencias básicas en educación primaria: una mirada desde la óptica docente. Profesorado. 
Revista de Curriculum y Formación del Profesorado, 20(1), 243-264. Recuperado de https://recyt.fecyt.es/index.php/profesorado/article/view/49878/30 503

Ramírez-García, A., y González-Fernández, N. (2016). Media competence of teachers and students of compulsory education in Spain. Comunicar, 24(49), 49-57. doi:10.3916/C49-2016-05

Ramírez-García, A., y Pérez del Arco, J. M. (2013). Normativa legal versus contexto escolar. La implementación de las competencias básicas en educación primaria. Cultura y Educación, 25(3), 399-414. doi:10.1174/113564013807749678

Ramírez-García, A., Renés Arellano, P., y García Ruiz, M. R. (2014). Presencia de la competencia mediática en los objetivos curriculares de la etapa de Educación Primaria. Teoría de la Educación. Revista Interuniversitaria, 26(1), 137-159. doi:10.14201/teoredu2014261137159

Ratcliffe, M. (2001). Science, technology and society in school science education. School Science Review, 82(300), 83-92. Recuperado de https://www.ase.org.uk/resources/school-science-review

Real Decreto 126/2014, de 28 de febrero, por el que se establece el currículo básico de la Educación Primaria. Boletín Oficial del Estado. Madrid, 1 de marzo de 2014, núm. 52, pp. 19349-19420.

Real Decreto 1105/2014, de 26 de diciembre, por el que se establece el currículo básico de la Educación Secundaria Obligatoria y del Bachillerato. Boletín Oficial del Estado. Madrid, 3 de enero de 2015, núm. 3, pp. 169-546.

REAL DECRETO 1513/2006, de 7 de diciembre, por el que se establecen las enseñanzas mínimas de la Educación primaria. Boletín Oficial del Estado. Madrid, 8 de diciembre de 2006, núm. 293, pp. 43053-43102.

Reeves, T. C. (2006). Design research from a technology perspective. En J. Van den Akker, K. Gravemeijer, S. McKenney y N. Nieveen (Eds.), Educational Design Research (pp. 52-66). Londres, Inglaterra: Routledge. 
del Rincón Igea, D., Arnal Agustín, J., Latorre Beltrán, A., y Sans Martín, A. (1995). Técnicas de investigación en ciancias sociales. Madrid, España: Dykinson.

Rip, A. (1979). The social context of 'science, technology and society' courses. Studies in Higher Education, 4(1), 15-26. doi:10.1080/03075077912331377061

Ritz, J. M., y Fan, SC. (2015). STEM and technology education: international state of the art. International Journal of Technology and Design Education, 25(4), 429-451. doi:10.1007/s10798-014-9290-z

Roegiers, X. (2008). Las reformas curriculares guían las escuelas: pero, ¿hacia dónde? Profesorado. Revista de Currículum y Formación del Profesorado, 12(3), 1-36.

Recuperado de https://recyt.fecyt.es/index.php/profesorado/article/view/42450/24 369

Roehrig, G. H., Moore, T. J., Wang, HH., y Park, M. S. (2012). Is adding the E enough? Investigating the Impact of K-12 engineering standards on the implementation of STEM integration. School Science and Mathematics, 112(1), 31-44. doi:10.1111/j.1949-8594.2011.00112.x

Romero Fernández, R., Rodríguez Miranda, F. P., y de las Heras Pérez, M. A. (2013). ¿Se trabaja por competencias el conocimiento del medio natural en primaria? Análisis del pensamiento del maestro y de los manuales escolares. Investigación en la Escuela, 81, 43-56. Recuperado de http://www.investigacionenlaescuela.es/articulos/81/R81-3.pdf

Rose, M. A. (2007) Perceptions of technological literacy among science, technology, engineering, and mathematics leaders. Journal of Technology Education, 19(1), 35-52. doi:10.21061/jte.v19i1.a.3

Rosselló Ramón, M. R., y Pinya Medina, C. (2014). La formación en competencias básicas: un reto para la administración. Profesorado. Revista de Currículum y Formación del Profesorado, 18(2), 245-265. Recuperado de https://recyt.fecyt.es/index.php/profesorado/article/view/41793/23 834

Ruiz Vicente, F. (2017). Diseño de proyectos STE AM a partir del curriculum actual de Educación Primaria utilizando Aprendizaje Basado en Problemas, Aprendizaje Cooperativo, Flipped Classroom y Robótica Educativa (Tesis doctoral). 
Recuperada

de

https://repositorioinstitucional.ceu.es/handle/10637/8739

Rychen, D. S., y Salganik, L. H. (Eds.). (2001). Defining and selecting key competencies. Gotinga, Alemania: Hogrefe \& Huber.

Rychen, D. S., y Salganik, L. H. (Eds.). (2003). Key competencies for a successful life and a well-functioning society. Gotinga, Alemania: Hogrefe \& Huber.

Sabariego Puig, M. (2004). El proceso de investigación (parte 2). En R. Bisquerra Alzina (Coord.), Metodología de la investigación educativa (pp. 127163). Madrid, España: La Muralla.

Said, Z., Summers, R., Abd-El-Khalick, F., y Wang, S. (2016). Attitudes toward science among grades 3 through 12 Arab students in Qatar: findings from a cross-sectional national study. International Journal of Science Education, 38(4), 621-643. doi:10.1080/09500693.2016.1156184

Salganik, L. H., Rychen, D. S., Moser, U., y Konstant, J. W. (1999). Projects on competencies in the OECD context. Analysis of theoretical and conceptual foundations. Recuperado del sitio de Internet de DeSeCo: http://deseco.ch/bfs/deseco/en/index/02.parsys.53466.downloadLi st.62701.DownloadFile.tmp/1999.projectsoncompetenciesanalysis.pd $\mathrm{f}$

Salmerón Pérez, H., Gutiérrez-Braojos, C., Rodríguez Fernández, S., y Salmerón Vílchez, P. (2010). Influencia del aprendizaje cooperativo en el desarrollo de la competencia para aprender a aprender en la infancia. Revista Española de Orientación y Psicopedagogía, 21(2), 308-319. Recuperado de https://www2.uned.es/reop/pdfs/2010/21-2 Honorio Salmeron.pdf

Sanders, M. (2008). STEM, STEM education, STEMmania. The Technology Teacher, 68(4), 20-26. Recuperado de https://www.questia.com/library/journal/1G1-190941545/stemstem-education-stemmania-a-series-of-circumstances

Sanmartí Puig, N. (2011). Competencias: ¿más burocracia o un constructo útil? En J. Vallès Villanueva, D. Álvarez Rodríguez y R. Rickenmann del Castillo (Eds.), L'activitat docent. Intervenció, innovació, investigació (pp. 8196). Gerona, España: Documenta Universitaria. 
Sarramona, J. (2000). Competencias básicas al término de la escolaridad obligatoria. Revista de Educación, 322, 255-288. Recuperado de http://www.mecd.gob.es/dctm/revista-de-

educacion/articulosre322/re3221608174.pdf?documentId=0901e72b $8125 \mathrm{f} 26 \mathrm{f}$

Sarramona, J. (2014). Competencias básicas y currículum. El caso de Cataluña. Teoría de la Educación. Revista Interuniversitaria, 26(2), 205-228. doi:10.14201/teoredu2014261205228

Saura, G., y Luengo Navas, J. (2015). Política global más allá de lo nacional. Reforma educativa (LOMCE) y el régimen de estandarización (OCDE). Bordón. Revista de Pedagogía, 67(1), 135-148. doi:10.13042/Bordon.2015.67109

Song, H-S., Kim, S-H., Song, Y-J., Yoo, P-R., Lee, J-Y., y Yu, H. (2019). Effect of STEAM education program using flexible display. International Journal of Information and Educational Technology, 9(8), 559-563. doi:10.18178/ijiet.2019.9.8.1266

Spiegel-Rösing, I., y de Solla Price, D. (Eds.). (1977). Science, technology and society: a cross-disciplinary perspective. Londres, Inglaterra: SAGE.

Spradley, J. P. (2016). Participant observation (2nd ed.). Long Grove, IL: Waveland Press.

Stenhouse, L. (1975). An introduction to curriculum research and development. Londres, Inglaterra: Heinemann.

Stewart-Brown, S., y Edmunds, L. (2003). Assessing emotional and social competence in preschool and primary school settings: A review of instruments. Perspectives in Education, 21(4), 17-40. Recuperado de https://journals.co.za/content/persed/21/4/EJC87228

Summers, R., y Abd-El-Khalick, F. (2018). Development and validation of an instrument to assess student attitudes toward science across grades 5 through 10. Journal of Research in Science Teaching, 55(2), 172-205. doi:10.1002/tea.21416

Summers, R., y Abd-El-Khalick, F. (2019). An exploration of Illinois students' attitudes toward science using multivariate multilevel modeling with a 
cross-sectional sample of responses from grades 5 through 10. Journal of Research in Science Teaching, 56(8), 1106-1134. doi:10.1002/tea.21552

Tala, S. (2009). Unified view of science and technology for education: technoscience and technoscience education. Science \& Education, 18(34), 275-298. doi:10.1007/s11191-008-9145-7

Tan, E., Calabrese Barton, A., y Benavides, A. (2019). Engineering for sustainable communities: epistemic tools in support of equitable and consequential middle school engineering. Science Education, 103(4), 1011-1046. doi:10.1002/sce.21515

Tardif, J. (2006). L'évaluation des compétences. Documenter le parcours de développement. Montreal, Canadá: Chenelière Éducation.

Tejada Fernández, J. (2011). La evaluación de las competencias en contextos no formales: dispositivos e instrumentos de evaluación. Revista de Educación, 354, 731-745. doi:10.4438/1988-592X-RE-2011-354-018

The Design-Based Research Collective. (2003). Design-based research: an emerging paradigm for educational inquiry. Educational Researcher, 32(1), 5-8. doi:10.3102/0013189X032001005

Tiana Ferrer, A. (2011). Análisis de las competencias básicas como núcleo curricular en la educación obligatoria española. Bordón. Revista de Pedagogía, 63(1), 63-75. Recuperado de https:// recyt.fecyt.es/index.php/BORDON/article/view/28905/154 10

Tiana, A., Moya, J., y Luengo, F. (2011). Implementing key competences in basic education: reflections on curriculum design and development in Spain. European Journal of Education, 46(3), 307-322. doi:10.1111/j.14653435.2011.01482.x

Toma, R. B., Ortiz-Revilla, J., y Greca, I. M. (2019). ¿Qué actitudes hacia la ciencia posee el alumnado de Educación Primaria que participa en actividades científicas extracurriculares? Ápice. Revista de Educación Cientifica, 3(1), 55-69. doi:10.17979/arec.2019.3.1.4599

Torres Santomé, J. (1994). Globalización e interdisciplinariedad: el curriculum integrado. Madrid, España: Morata. 
Trentacosta, C. J., Izard, C. E., Mostow, A. J., y Fine, S. E. (2006). Children's emotional competence and attentional competence in early elementary school. School Psychology Quarterly, 21(2), 148-170. doi:10.1521/scpq.2006.21.2.148

United Nations Educational, Scientific and Cultural Organization. (2016). Education 2030. Incheon Declaration and framework for action for the implementation of sustainable development goal 4. Recuperado de http:/ / unesdoc.unesco.org/images/0024/002456/245656E.pdf

United Nations Educational, Scientific and Cultural Organization. (2017). Cracking the code: Girls' and women's education in science, technology, engineering and mathematics (STEM). París, Francia: Autor.

Valanides, N., y Angeli, C. (2008). Distributed cognition in a sixth-grade classroom: an attempt to overcome alternative conceptions about light and color. Journal of Research on Technology in Education, 40(3), 309-336. doi: 10.1080/15391523.2008.10782510

Valle, J., y Manso, J. (2013). Competencias clave como tendencia de la política educativa supranacional de la Unión Europea. Revista de Educación, $N^{o}$ Extraordinario, 12-33. doi:10.4438/1988-592X-RE-2013-EXT-255

Vanderlinde, R., y van Braak, J. (2010). The gap between educational research and practice: views of teachers, school leaders, intermediaries and researchers. British Educational Research Journal, 36(2), 299-316. doi:10.1080/01411920902919257

Vázquez Alonso, Á., y Manassero Mas, M. A. (2008). El declive de las actitudes hacia la ciencia de los estudiantes: un indicador inquietante para la educación científica. Revista Eureka sobre Enseñanza y Divulgación de las Ciencias, 5(3), 274-292. Recuperado de http:/ / revistas.uca.es/index.php/eureka/article/view/3740

Vergnaud, G. (1982). A classification of cognitive tasks and operations of thought involved in addition and subtraction problems. En T. P. Carpenter, J. M. Moser y T. A. Romberg (Eds.), Addition and subtraction: a cognitive perspective (pp. 39-59). Hillsdale, NJ: Lawrence Erlbaum Associates.

Vergnaud, G. (1990). La théorie des champs conceptuels. Recherches en Didactique des Mathématiques, 10(2.3), 133-170. Recuperado de 
http://rdm.penseesauvage.com/La-theorie-des-champsconceptuels.html

Vergnaud, G. (1996). Algunas ideas fundamentales de Piaget en torno a la didáctica. Perspectivas, 26(1), 195-207. Recuperado de http://www.ibe.unesco.org/sites/default/files/resources/prospects97_spa.pdf

Vergnaud, G. (1998). A comprehensive theory of representation for mathematics education. Journal of Mathematical Behavior, 17(2), 167-181. doi:10.1016/S0364-0213(99)80057-3

Vergnaud, G. (2007). ¿En qué sentido la teoría de los campos conceptuales puede ayudarnos para facilitar aprendizaje significativo? Investigações em Ensino de Ciências, 12(2), 285-302. Recuperado de https://www.if.ufrgs.br/cref/ojs/index.php/ienci/article/view/475/ 277

Vergnaud, G. (2013). ¿Por qué la teoría de los campos conceptuales? Infancia y Aprendizaje, 36(2), 131-161. doi:10.1174/021037013806196283

Vesterinen, V-M., Manassero-Mas, M-A., y Vázquez-Alonso, Á. (2014). History, philosophy, and sociology of science and science-technologysociety traditions in science education: continuities and discontinuities. En M. R. Matthews (Ed.), International handbook of research in bistory, philosophy and science teaching. Volume III (pp. 1895-1925). Dordrecht, Países Bajos: Springer.

Vicente, S., Rosales, J., Chamoso, J. M., y Múñez, D. (2013). Análisis de la práctica educativa en clases de matemáticas españolas de Educación Primaria: una posible explicación para el nivel de competencia de los alumnos. Cultura y Educación, 25(4), 535-548. doi:10.1174/113564013808906799

Villa Sánchez, A., y Poblete Ruiz, M. (Eds.). (2008). Aprendizaje basado en competencias. Una propuesta para la evaluación de las competencias genéricas. Bilbao, España: Ediciones Mensajero.

Vincent, B. B., y Loeve, s. (2018).Toward a philosophy of technosciences. En S. Loeve, X. Guchet y B. B. Vincent (Eds.), French philosophy of technology: classical readings and contemporary approaches (pp. 169-186). Cahm, Suiza: Springer. 
Volti, R. (2014). Society and technological change (7th ed.). Nueva York, NY: Worth. von Hippel, E. (2005). Democratizing innovation: the evolving phenomenon of user innovation. Management Review Quarterly, 55(1), 63-78. doi:10.1007/s11301-004-0002-8

Vygotsky, L. S. (1962). Thought and language. Cambridge, MA: The MIT Press.

Vygotsky, L. S. (1978). Mind in society: the development of higher psychological processes. Cambridge, MA: Harvard University Press.

Waight, N., \& Abd-El-Khalick, F. (2012) Nature of technology: implications for design, development, and enactment of technological tools in school science classrooms. International Journal of Science Education, 34(18), 2875-2905. doi:10.1080/09500693.2012.698763

Wang, HH., Moore, T. J., Roehrig, G. H., y Park, M. S. (2011). STEM integration: teacher perceptions and practice. Journal of Pre-College Engineering Education Research, 1(2), 1-13. doi:10.5703/1288284314636

Warnick, B. R., y Stemhagen, K. (2007). Mathematics teachers as moral educators: the implications of conceiving of mathematics as a technology. Journal of Curriculum Studies, 39(3), 303-316. doi:10.1080/00220270600977683

Weinert, F. E. (1999). Concepts of competence. Recuperado del sitio de Internet de Semantic Scholar: https://pdfs.semanticscholar.org/8b88/efa9dd5e0a4b605aea6e5e3b9 ec640beb089.pdf

Wentzel, K. R. (1991). Social competence at school: relation between social resposibility and academic achievement. Review of Educational Research, 61(1), 1-24. doi:10.3102/00346543061001001

Williams, J. P. (2011). STEM education: proceed with caution. Design and Technology Education: An International Journal, 16(1), 26-35. Recuperado de https://ojs.lboro.ac.uk/DATE/article/view/1590/1514

Yao, J.-X., y Guo, Y.-Y. (2018). Core competences and scientific literacy: the recent reform of the school science curriculum in China. International Journal of Science Education, 1-21. doi:10.1080/09500693.2018.1514544 
Yus Ramos, R., Fernández Navas, M., Gallardo Gil, M., Barquín Ruiz, J., Sepúlveda Ruiz, M. P., y Serván Núñez, M. J. (2013). La competencia científica y su evaluación. Análisis de las pruebas estandarizadas de PISA. Revista de Educación, 360, 557-576. doi:10.4438/1988-592X-RE2011-360-127

Zabala, A., y Arnau, L. (2007). 11 ideas clave. Cómo aprender y enseñar competencias. Barcelona, España: Graó.

Zeidler, D. L. (2016). STEM education: a deficit framework for the twenty first century? A sociocultural socioscientific response. Cultural Studies of Science Education, 11(1), 11-26. doi:10.1007/s11422-014-9578-z

Zeidler, D. L., y Sadler, T. D. (2007). The role of moral reasoning in argumentation: conscience, character, and care. En S. Erduran y M. P. Jiménez-Aleixandre (Eds.), Argumentation in science education: perspectives from classroom-based research (pp. 201-216). Dordrecht, Países Bajos: Springer.

Ziman, J. (1980). Teaching and learning about science and society. Cambridge, Inglaterra: Cambridge University Press.

Zollman, A. (2012). Learning for STEM literacy: STEM literacy for learning. School Science and Mathematics, 112(1), 12-19. doi:10.1111/j.19498594.2012.00101.x 


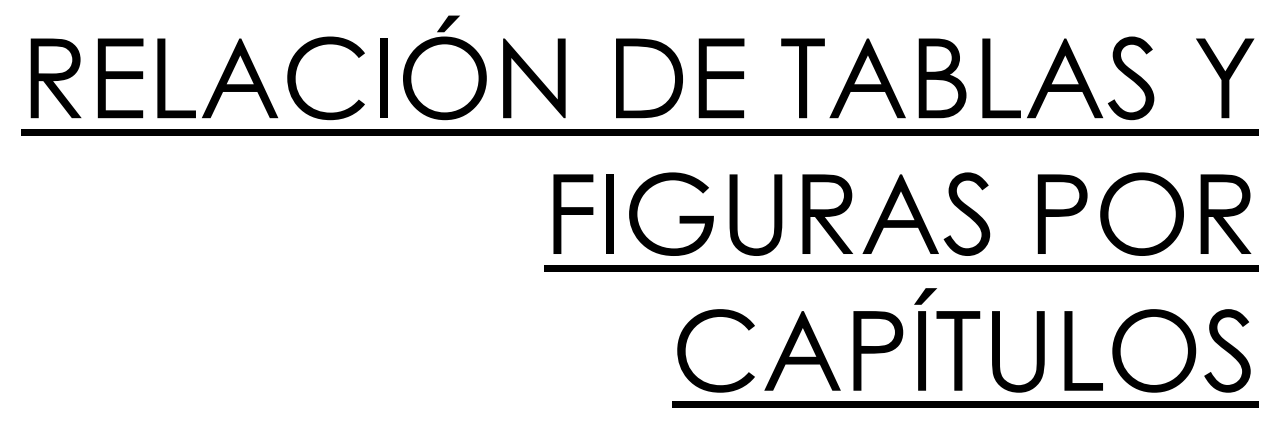





\section{CAPÍTULO 2}

Tabla 2.1. Síntesis de las dimensiones competenciales y sus criterios operativos .46

Tabla 2.2. Mapeo general de los estudios finales 49

Tabla 2.3. Datos de la revisión en profundidad de los 38 estudios finales ..... 54

\section{CAPÍTULO 4}

Table 4.1. Some features for a FRA model for NOSTEM 113

\section{CAPÍTULO 5}

Tabla 5.1. Relación de los aspectos trabajados en cada disciplina STEAM.. 126

Tabla 5.2. Objetivos principales de la propuesta divididos por disciplinas

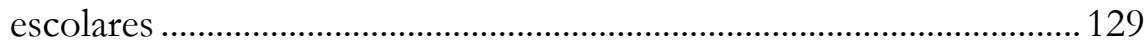

Tabla 5.3. Relación y explicación general de las sesiones ................................... 131

\section{CAPÍTULO 6}

Tabla 6.1. Recuento de la muestra según edad, género y prototipo................ 160

Tabla 6.2. Recuento de la muestra según edad, género y grupo ...................... 161

Tabla 6.3. Datos de la valoración interjueces y tasa de acuerdo con el investigador y los maestros ...................................................................... 166

Tabla 6.4. Conteo y porcentajes de acuerdos y desacuerdos............................. 167

Tabla 6.5. Prueba de Kolmogorov-Smirnov para la muestra total................. 168

Tabla 6.6. Prueba de Kolmogorov-Smirnov y Shapiro-Wilk para muestras segmentadas por prototipo .................................................................... 168

Tabla 6.7. Prueba de Kolmogorov-Smirnov para la muestra total................. 170

Tabla 6.8. Prueba de Kolmogorov-Smirnov para la muestra agrupada de quinto

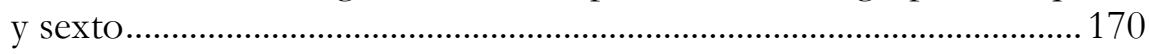

\section{CAPÍTULO 7}

Tabla 7.1. Ejemplos de notas de campo para cada categoría 176 
Tabla 7.2. Estadísticos descriptivos de la evaluación competencial en el Prototipo 1

Tabla 7.3. Porcentajes y niveles de consecución competencial en el Prototipo 1 178

Tabla 7.4. Prueba U de Mann Whitney controlando la variable género en el Prototipo 1 178

Tabla 7.5. Estadísticos descriptivos de las actitudes e intenciones en el Prototipo 1 179

Tabla 7.6. Estadísticos descriptivos de la evaluación competencial en el Prototipo 2

Tabla 7.7. Porcentajes y niveles de consecución competencial en el Prototipo 2 184

Tabla 7.8. Prueba U de Mann Whitney controlando la variable género en el

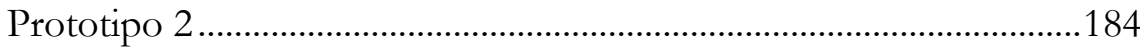

Tabla 7.9. Estadísticos descriptivos de las actitudes e intenciones en el

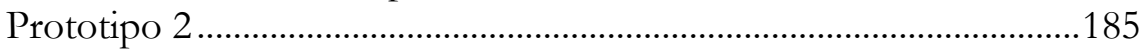

Tabla 7.10. Estadísticos descriptivos de la evaluación competencial en el Prototipo 3

Tabla 7.11. Porcentajes y niveles de consecución competencial en el Prototipo 3 187

Tabla 7.12. Prueba U de Mann Whitney controlando la variable género en el Prototipo 3 188

Tabla 7.13. Estadísticos descriptivos de la evaluación competencial por género en el Prototipo 3 ……………………..................................................188

Tabla 7.14. Estadísticos descriptivos de las actitudes e intenciones en el Prototipo 3

Tabla 7.15. Estadísticos descriptivos de la evaluación competencial del total de la muestra 189

Tabla 7.16. Porcentajes y niveles de consecución competencial en el total de la muestra 190

Tabla 7.17. Prueba U de Mann-Whitney controlando la variable género en el total de la muestra 
Tabla 7.18. Estadísticos descriptivos de la evaluación competencial por género en el total de la muestra. 191

Tabla 7.19. Prueba H de Kruskal-Wallis controlando la variable prototipo en el total de la muestra...... 192

Tabla 7.20. Prueba H de Kruskal-Wallis controlando la variable grupo en el total de la muestra 198

Tabla 7.21. Estadísticos descriptivos de las actividades e intenciones en el total de la muestra 200

Tabla 7.22. Prueba U de Mann-Whitney controlando la variable género en el total de la muestra.. 200

Tabla 7.23. Estadísticos descriptivos de la evaluación de los cuatro constructos por género en el total de la muestra......................................................... 201

Tabla 7.24. Prueba H de Kruskal-Wallis controlando la variable prototipo en el total de la muestra......................................................................................... 202

Tabla 7.25. Prueba U de Mann Whitney controlando la variable curso........ 205

Tabla 7.26. Estadísticos descriptivos de la evaluación de actitudes hacia la ciencia por cursos 205

Tabla 7.27. Tabla de rangos de la prueba U de Mann-Whitney controlando la variable curso. 206

Tabla 7.28. Comparación de medias obtenidas en dos constructos con el instrumento BRAINS con muestras de alumnado de sexto curso ... 216

\section{CAPÍTULO 2}

Figura 2.1. Distribución de publicaciones por quinquenio 48

Figura 2.2. Distribución geográfica de los estudios finales. 51

Figura 2.3. Distribución de los estudios finales agrupados por tipo de competencia abordada. 52

Figura 2.4. Distribución de la muestra atendiendo a las dimensiones competenciales abordadas. 57

\section{CAPÍTULO 3}

Figure 3.1. General scheme of the Triadic Network. From Laudan (1984)... 73 
Figure 3.2. Model of triadic functioning for the theoretical framework of integrated STEM education........................................................................76

Figure 3.3. Outline of the student conceptualization model and its influential

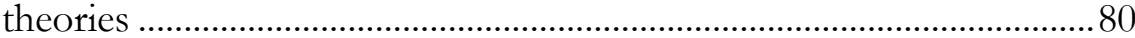

Figure 3.4. Transformation of a traditional objective into other objectives based

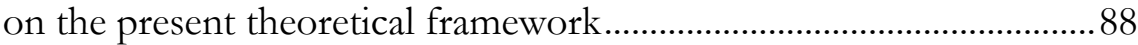

Figure 3.5. Model of triadic functioning corresponding to an example of application of the theoretical framework in the design, implementation, and evaluation of a STEAM didactic unit in the stage of primary education

\section{CAPÍTULO 5}

Figura 5.1. Modelo de funcionamiento triádico para el encuadre teórico de la educación STEAM integrada

Figura 5.2. Modelo transdisciplinario para la educación STEAM integrada.123

Figura 5.3. Mapa conceptual de los contenidos abordados a lo largo de la unidad didáctica.

Figura 5.4. Algunos experimentos con electricidad estática realizados por el alumnado 135

Figura 5.5. Algunos experimentos con circuitos realizados por el alumnado 136

Figura 5.6. Escolares recogiendo información sobre los distintos tipos de

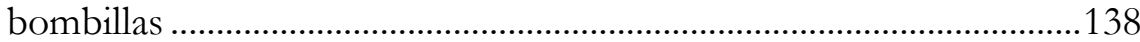

Figura 5.7. Realización de gráficos de barras .......................................................139

Figura 5.8. Proceso de construcción de gráficos sectoriales...............................141

Figura 5.9. Escolares indagando acerca de la luz y el color ...............................143

Figura 5.10. Ejemplos de composiciones artísticas realizadas por el alumnado 144

Figura 5.11. Algunos momentos del proceso de diseño y mejora del prototipo 146 


\section{CAPÍTULO 6}

Figura 6.1. Diagrama del diseño de métodos mixtos paralelo convergente QUAL + quan empleado en la investigación. Adaptada de Creswell y Plano Clark (2018) 154

Figura 6.2. Esquema de la secuenciación de las tres iteraciones y los tres prototipos. Adaptada de Ortiz-Revilla, Greca y Meneses Villagrá (2019) 162

Figura 6.3. Síntesis de la información del diseño metodológico creado enmarcada en el diagrama del diseño de métodos mixtos paralelo convergente QUAL + quan empleado en la investigación... 172

\section{CAPÍTULO 7}

Figura 7.1. Diagrama de cajas y bigotes y gráfico de nodos correspondientes al caso de la CG 193

Figura 7.2. Diagrama de cajas y bigotes y gráfico de nodos correspondientes al caso de la CCL 194

Figura 7.3. Diagrama de cajas y bigotes y gráfico de nodos correspondientes al caso de la CD 194

Figura 7.4. Diagrama de cajas y bigotes y gráfico de nodos correspondientes al caso del SIE 195

Figura 7.5. Diagrama de cajas y bigotes y gráfico de nodos correspondientes al

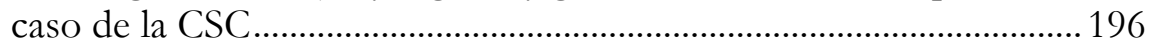

Figura 7.6. Diagrama de cajas y bigotes correspondiente al caso de la CMCT 196

Figura 7.7. Diagrama de cajas y bigotes correspondiente al caso de la CPAA 197

Figura 7.8. Diagrama de cajas y bigotes correspondiente al caso de las CSC 197

Figura 7.9. Diagrama de cajas y bigotes y gráfico de nodos correspondientes al caso de la CD

Figura 7.10. Diagrama de cajas y bigotes y gráfico de nodos correspondientes al caso del constructo de Actitudes hacia la ciencia 
Figura 7.11. Diagrama de cajas y bigotes correspondiente al caso del constructo

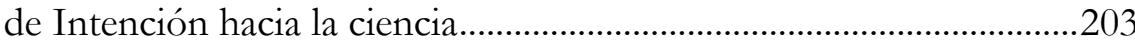

Figura 7.12. Diagrama de cajas y bigotes correspondiente al caso del constructo de Intención hacia la ingeniería...................................................................203

Figura 7.13. Diagrama de cajas y bigotes correspondiente al caso del constructo

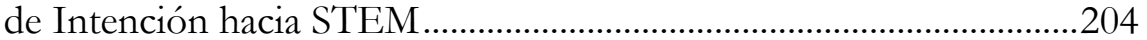

Figura 7.14. Barras de error con M y DE de la Intención hacia la ciencia a lo largo de los tres prototipos........................................................................208

Figura 7.15. Barras de error con M y DE de las Actitudes hacia la ciencia a lo largo de los tres prototipos....................................................................208

Figura 7.16. Barras de error con M y DE de la Intención hacia la ciencia a lo largo de los tres prototipos....................................................................209

Figura 7.17. Barras de error con M y DE de la Intención hacia la ingeniería a lo largo de los tres prototipos ....................................................................209

Figura 7.18. Barras de error con M y DE de la Intención hacia STEM a lo largo de los tres prototipos .................................................................................210

Figura 7.19. Gráfico de líneas con M de la CMCT y de los cuatro constructos a lo largo de los tres prototipos 
RELACIÓN DE SIGLAS 

AAAS (American Association for the Advancement of Science)

CCC (Cross-Curricular Competencies)

CCL (Competencia en comunicación lingüística)

CCP (Comisión de Coordinación Pedagógica)

$\mathrm{CD}$ (Competencia digital)

CEC (Conciencia y expresiones culturales)

CEIP (Colegio de Educación Infantil y Primaria)

CG (Competencia general)

CMCT (Competencia matemática y competencias básicas en ciencia y tecnología)

COSCE (Confederación de Sociedades Científicas de España)

CyL (Castilla y León)

CPAA (Competencia para aprender a aprender)

CSC (Competencias sociales y cívicas)

DBRC (The Design-Based Research Collective)

DeSeCo (Definition and Selection of Competencies)

EAE (Estándar de aprendizaje evaluable)

EAEG (EAE Global)

EC (European Commission)

ECBI (Enseñanza de las ciencias basada en la indagación)

ESO (Educación Secundaria Obligatoria)

FRA (Family resemblance approach)

HCI (Human Capital Indicators)

IALS (International Adult Literacy Survey)

IBL (Inquiry-based learning)

IBSE (Inquiry-based science education)

INES (Indicators of National Education Systems)

JCR (Journal Citation Reports)

JCyL (Junta de Castilla y León)

LED (light-emitting diode)

LGE (LEY 14/1970, de 4 de agosto, General de Educación y Financiamiento de la Reforma Educativa)

LOCE (LEY ORGÁNICA 10/2002, de 23 de diciembre, de Calidad de la Educación)

LOE (LEY ORGÁNICA 2/2006, de 3 de mayo, de Educación)

LOGSE (LEY ORGÁNICA 1/1990, de 3 de octubre, de Ordenación General del Sistema Educativo)

LOMCE (Ley Orgánica 8/2013, de 9 de diciembre, para la mejora de la calidad educativa)

ME (Ministerio de Educación) 
MECD (Ministerio de Educación, Cultura y Deporte)

NOE (Nature of engineering)

NOM (Nature of mathematics)

NOS (Nature of science)

NOSTEM (Nature of STEM)

NOT (Nature of technology)

NRC (National Research Council)

NSB (National Science Board)

NSF (National Science Foundation)

OCDE (Organización para la Cooperación y el Desarrollo Económicos)

OE (Objetivo específico)

OECD (Organisation for Economic Co-operation and Development)

OG (Objetivo general)

PBL (Project Based Learning)

PIRLS (Progress in International Reading Literacy Study)

PISA (Programme for International Student Assessment)

RD (Real Decreto)

SIE (Sentido de la iniciativa y espíritu emprendedor)

SSI (Socio-scientific issues)

SSIBL (Socio-scientific inquiry-based learning)

STEAM (Science, Technology, Engineering, Arts and Mathematics)

STEM (Science, Technology, Engineering and Mathematics)

STS (Science-technology-society)

STSE (Science-technology-society, environment)

$\mathrm{T}$ (Tarea)

TIC (Tecnologías de la Información y de la Comunicación)

TIMSS (Trends in International Mathematics and Science Study)

UD (Unidad Didáctica)

UNESCO (Organización de las Naciones Unidas para la Educación, la Ciencia y la Cultura) 
ANEXOS 



\section{Anexo 5.1. Ejemplos de concepciones alternativas catalogadas en la literatura sobre los contenidos abordados en la UD}

- Cuando el alumnado observa objetos de colores bajo luz blanca, considera que el color es una cualidad del objeto, independientemente de la fuente de luz o del receptor (Anderson y Smith, 1986; Guesne, 1985).

- A menudo, los escolares piensan que el «color está en el objeto» (Feher y Rice Meyer, 1992).

- Algunos estudiantes conceptualizan la luz como una sustancia que puede cubrir todos los objetos de una habitación (Valanides y Angeli, 2008).

- Algunos escolares conciben la corriente eléctrica como una sustancia que se mueve en los cables (Gupta, Elby y Conlin, 2014).

- La corriente que suministra la pila se gasta a lo largo del circuito, es suficiente la conexión a un solo terminal de la batería para que en un circuito elemental se enciendan las bombillas, la pila es la única y constante fuente de cargas - se considere como electrones o fluidoque se inyecta en los cables como el agua en una cañería (Hierrezuelo Moreno et al., 1995).

- La reorganización de los datos brutos es descrita, en general, como «tortuosa» para los escolares (Kinnear, 2013). 


\section{Anexo 5.2. Contenidos curriculares abordados en la UD}

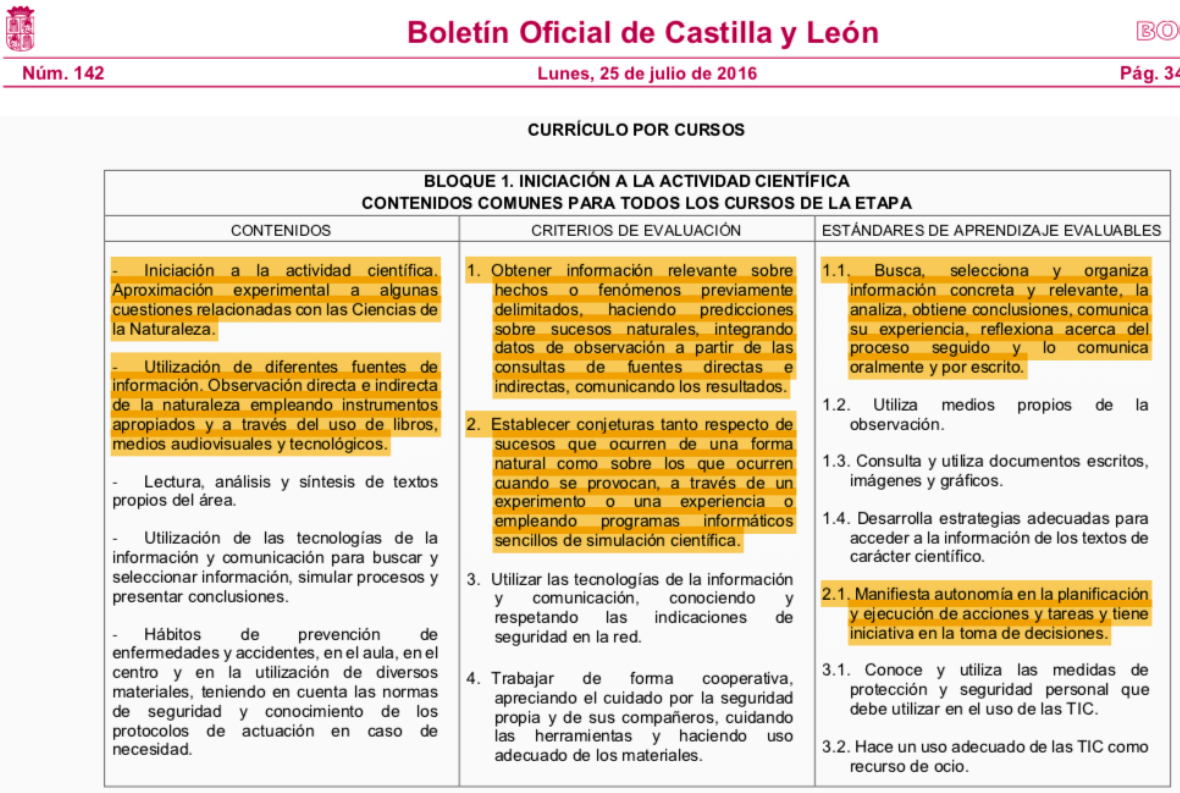

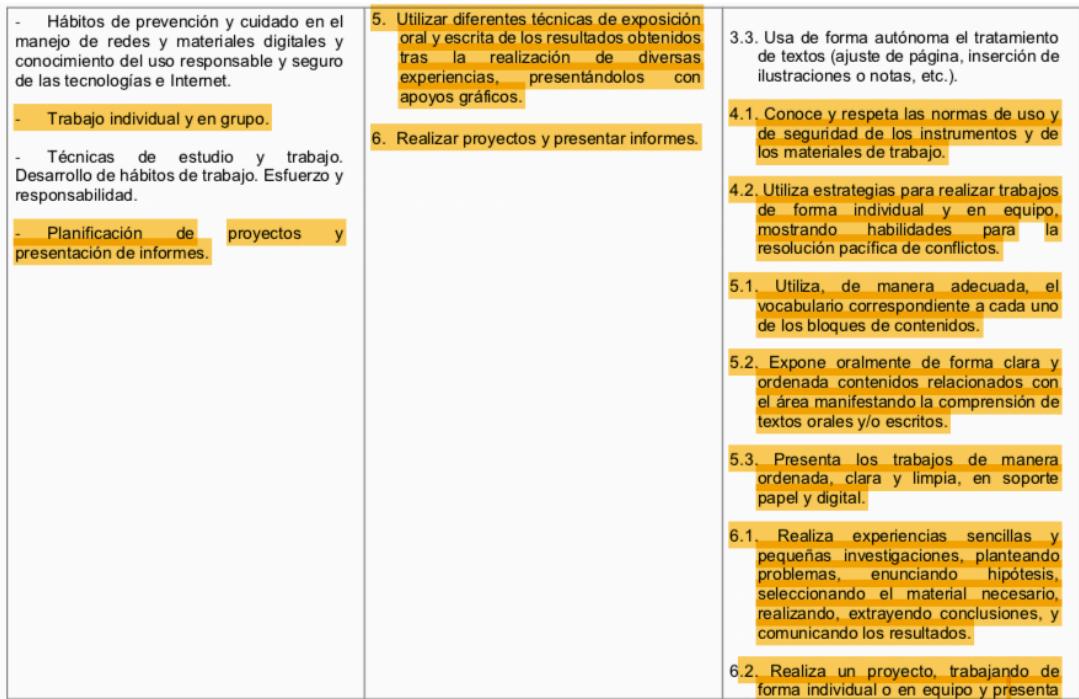




\begin{tabular}{|l|l|l|}
\hline & $\begin{array}{l}\text { un informe, utilizando soporte papel y/o } \\
\text { digital, recogiendo información de }\end{array}$ \\
& $\begin{array}{l}\text { diferentes fuentes (directas, libros, } \\
\text { Intemet), con diferentes medios y }\end{array}$ \\
& $\begin{array}{l}\text { comunicando de forma oral la } \\
\text { experiencia realizada, apoyándose en }\end{array}$ \\
\hline
\end{tabular}

\begin{tabular}{|c|c|c|}
\hline \multicolumn{3}{|c|}{$\begin{array}{l}\text { PRIMER CURSO } \\
\text { BLOQUE 2. EL SER HUMANO Y LA SALUD }\end{array}$} \\
\hline CONTENIDOS & CRITERIOS DE EVALUACIÓN & ESTÁNDARES DE APRENDIZAJE EVALUABLES \\
\hline $\begin{array}{l}\text { El cuerpo humano. Partes del cuerpo. } \\
\text { Huesos y músculos. } \\
\text { - Órganos de los sentidos. } \\
\text { - Alimentos y alimentación. } \\
\text { - Salud y enfermedad. } \\
\text { - Hábitos saludables. } \\
\text { Conocimiento de actuaciones básicas } \\
\text { ante accidentes escolares. } \\
\text { demás. }\end{array}$ & $\begin{array}{l}\text { 1. Identificar y reconocer las partes del } \\
\text { cuerpo humano y las funciones de } \\
\text { huesos, músculos y los órganos de los } \\
\text { sentidos. } \\
\text { 2. Identificar la importancia de los } \\
\text { alimentos y la alimentación adecuada. } \\
\text { 3. Relacionar determinadas prácticas de } \\
\text { vida con el adecuado funcionamiento del } \\
\text { cuerpo y el mantenimiento de la salud. } \\
\text { 4. Conocer el protocolo de actuación del } \\
\text { centro ante accidentes escolares. } \\
\text { 5. Conocer y valorar la relación entre el } \\
\text { bienestar y la identificación de sus } \\
\text { emociones y las de sus compañeros. }\end{array}$ & $\begin{array}{l}\text { 1.1. Identifica y describe las partes del } \\
\text { cuerpo humano. } \\
\text { 1.2. Conoce las funciones de huesos y } \\
\text { músculos. } \\
\text { 1.3 Asocia los órganos de los sentidos y la } \\
\text { información que proporcionan. } \\
\text { 2.1. Clasifica alimentos según su origen y su } \\
\text { aportación a la dieta. } \\
\text { 3.1. Reconoce estilos de vida saludables y } \\
\text { sus efectos sobre el cuidado y } \\
\text { mantenimiento de los diferentes órganos } \\
\text { y aparatos. } \\
\text { 3.2. Identifica y adopta hábitos de higiene, } \\
\text { cuidado y descanso. }\end{array}$ \\
\hline
\end{tabular}

\begin{tabular}{|l|l|l|}
\hline & $\begin{array}{l}\text { 3.1. Muestra conductas de respeto y cuidado } \\
\text { hacia los seres vivos. } \\
\text { 3.2. Usa la lupa y otros medios tecnológicos } \\
\text { en los diferentes trabajos que realiza. } \\
\text { 3.3. Manifiesta una cierta precisión y rigor en } \\
\text { la observación y en la elaboración de los } \\
\text { trabajos. } \\
\text { 3.4. Observa y registra algún proceso } \\
\text { asociado a la vida de los seres vivos, } \\
\text { utilizando los instrumentos y los medios } \\
\text { audiovisuales y tecnológicos apropiados, } \\
\text { comunicando de manera oral y escrita los } \\
\text { resultados. } \\
\text { 3.5. Respeta las normas de uso, de seguridad } \\
\text { y de mantenimiento de los instrumentos } \\
\text { de observación y de los materiales de } \\
\text { trabajo. }\end{array}$ \\
\hline
\end{tabular}

\begin{tabular}{|c|c|c|}
\hline \multicolumn{3}{|c|}{ BLOQUE 4. MATERIA Y ENERGIAA } \\
\hline CONTENIDOS & CRITERIOS DE EVALUACIÓN & ESTÁNDARES DE APRENDIZAJE EVAL UABLES \\
\hline $\begin{array}{l}\text { Diferentes procedimientos para la medida } \\
\text { del volumen de un cuerpo. } \\
\text { Predicción de alteraciones en el } \\
\text { movimiento y en la forma de los cuerpos por } \\
\text { efecto de las fuerzas y los cambios de estado. }\end{array}$ & $\begin{array}{l}\text { 1. Conocer los procedimientos para la } \\
\text { medida del volumen de un cuerpo. } \\
\text { 2. Conocer leyes básicas que rigen la } \\
\text { transmisión de la corriente eléctrica y } \\
\text { analizar fenómenos de naturaleza } \\
\text { eléctrica. }\end{array}$ & $\begin{array}{l}\text { 1.1. Realiza la medida del volumen de un } \\
\text { cuerpo. } \\
\text { 2.1. Conoce las leyes básicas que rigen la } \\
\text { transmisión de la corriente eléctrica. }\end{array}$ \\
\hline
\end{tabular}




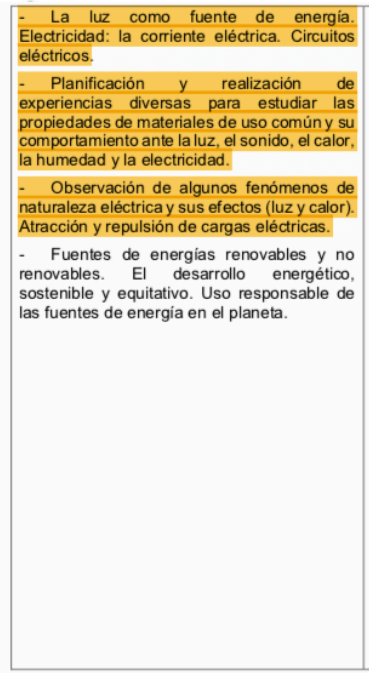

3. Planificar y realizar sencillas investigaciones prediciendo comportamiento de los cuerpos ante la electricidad siguiendo los pasos del étodo científico y empleando programas de simulación.

4. Comprender el concepto y tipos de energía diferenciando las distintas fuentes $y$ valorando su origen, caracteristicas, la importancia de hacer un uso responsable y asociando la energía al emprendimiento empresarial y a las actividades económicas.

\subsection{Observa, identifica y explica algunos} fectos de la electricidad

2.3. Expone ejemplos de materiales conductores y aislantes, argumentado su exposición.

3.1. Planifica y realiza sencillas experiencias y predice cambios en el movimiento, en la forma o en el estado de los cuerpos por dectode las iuerzas ode las aportaciones de energia, comunicando el pro seguido y el resultado obtenido.

3.2. Realiza pequeños experimentos para estudiar la atracción y repulsión de cargas eléctricas.

3.3 Empleo de programas de simulación científica para la predicción de resultados.

4.1. Identifica y explica algunas de las principales características de las energías renovables y no renovables, identificando las diferentes fuentes de energia $y$ materias primas y el origen de las que provienen.

4.2. Identifica y explica los beneficios y riesgos (agotamiento, lluvia ácida, radiactividad, efecto invernadero) relacionados con la utilización de la energia, exponiendo posibles actuaciones para un desarrollo sostenible.

\begin{tabular}{|l|l|l|}
\hline & $\begin{array}{c}\text { 4.3. Explica la importancia de la explotación y } \\
\text { aprovechamiento de los recursos de } \\
\text { manera sostenible y lo vincula a la } \\
\text { actividad económica. }\end{array}$ \\
\hline
\end{tabular}

\begin{tabular}{|c|c|c|}
\hline \multicolumn{3}{|c|}{ BLOQUE 5. LA TECNOLOGIA, OBJETOS Y MÁQUINAS } \\
\hline CONTENIDOS & CRITERIOS DE EVALUACIÓN & ESTÁNDARES DE APRENDIZAJE EVALUABLES \\
\hline $\begin{array}{l}\text { Máquinas y aparatos. Tipos de máquinas. } \\
\text { Utilidad y ejemplos en la vida cotidiana. } \\
\text { - Análisis y funciones de operadores y } \\
\text { utilización en la construcción de un aparato. } \\
\text { - Construcción de estructuras sencillas que } \\
\text { cumplan una función o condición para } \\
\text { resolver un problema a partir de piezas } \\
\text { moduladas. Planificación, montaje y } \\
\text { desmontaje. } \\
\text { máquanas. Electricidad en el desarrollo de las de los circuitos } \\
\text { eléctricos. Efectos de la electricidad. } \\
\text { Conductores y aislantes. } \\
\text { Magnetismo. El imán. La relación entre la } \\
\text { electricidad y el magnetismo. } \\
\text { sociedad. Mejora de las condiciones de vida: } \\
\text { vivienda, medicina, transportes, } \\
\text { comunicaciones e industria. }\end{array}$ & $\begin{array}{l}\text { 1. Conocer los componentes y los principios } \\
\text { básicos que rigen máquinas y aparatos } \\
\text { diferenciando y enunciando ejemplos de } \\
\text { máquinas simples y compuestas de uso } \\
\text { frecuente. } \\
\text { 2. Planificar con el diseño previo de } \\
\text { esquemas, simuladores o dibujos la } \\
\text { construcción de objetos y aparatos con } \\
\text { una finalidad previa, utilizando fuentes } \\
\text { energéticas, operadores y materiales } \\
\text { apropiados, realizando el trabajo } \\
\text { individual y en equipo, y proporcionando } \\
\text { información sobre qué estrategias se han } \\
\text { empleado. } \\
\text { 3. Realiza experiencias sencillas y pequeñas } \\
\text { investigaciones sobre la electricidad, el } \\
\text { magnetismo y su utilización: planteando } \\
\text { problemas, enunciando hipótesis, } \\
\text { seleccionando el material necesario, } \\
\text { realizando el montaje, extrayendo } \\
\text { conclusiones y comunicando resultados. }\end{array}$ & $\begin{array}{l}\text { 1.1. Identifica diferentes tipos de máquinas, y } \\
\text { las clasifica según el número de piezas, la } \\
\text { manera de accionarlas, y la acción que } \\
\text { realizan. } \\
\text { 1.2. Observa, identifica y describe algunos de } \\
\text { los componentes de las máquinas. } \\
\text { 1.3. Observa e identifica alguna de las } \\
\text { aplicaciones de las máquinas y aparatos, } \\
\text { y su utilidad para facilitar las actividades } \\
\text { humanas. } \\
\text { 2.1. Construye alguna estructura sencilla que } \\
\text { cumpla una función o condición para } \\
\text { resolver un problema a partir de piezas } \\
\text { moduladas. } \\
\text { 3.1. Observa e identifica los elementos de un } \\
\text { circuito eléctrico aplicándolos para } \\
\text { construir uno. }\end{array}$ \\
\hline
\end{tabular}




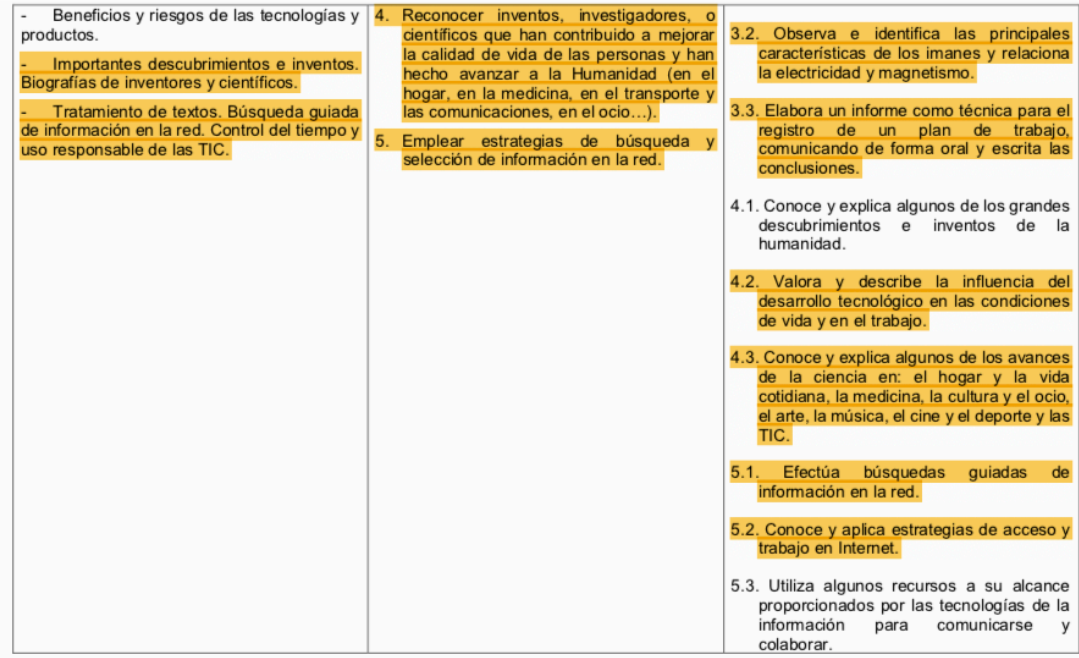

\section{CURRICULO POR CURSOS}

BLOQUE 1. PROCESOS, MÉTODOS Y ACTITUDES EN MATEMÁTICAS. Bloque común de primero a sexto. CONTENIDOS

- Planificación del proceso de resolución de problemas:

Análisis y comprensión del enunciado.

Estrategias y procedimientos: gráficos ablas, esquemas de la situación, datos, planteamiento, ensayo y error razonado, selección de las operaciones, etc.

Estimación del resultado de un cálculo y realización de los cálculos necesarios.

Resultados obtenidos y valoración de los mismos.

Explicación de forma oral y por escrito de de los resultados obtenidos.

- Planteamiento de pequeñas investigaciones en contextos numéricos, geométricos y funcionales.

Utilización de algoritmos estándar en los contextos de resolución de problemas $y$ valoración de otras posibilidades de resolución CRITERIOS DE EVALUACIÓN

ESTÁNDARES DE APRENDIZAJE EVALUABLES

1. Utilizar procesos de razonamiento estrategias de resolución de problemas realizando los cálculos necesarios comprobando las soluciones obtenidas.

2. Expresar verbalmente de forma razonada el proceso seguido en la resolución de un problema.

3. Describir y analizar situaciones de cambio para encontrar patrones, regularidades y leyes matemáticas, en contextos numéricos, geométricos y funcionales, valorando su utilidad para hacer predicciones.

4. Profundizar en problemas resueltos planteando pequeñas variaciones en los datos, otras preguntas, etc.

5. Realizar y presentar informes sencillos sobre el desarrollo, resultados sobre el desarrollo, resultados y investigación.

6. Planificar y controlar las fases de método de trabajo cientifico en situaciones adecuadas al nivel.
1.1 Analiza y comprende el enunciado de los problemas (datos, relaciones entre los datos, contexto del problema).

1.2 Utiliza estrategias heurísticas y procesos de razonamiento en la resolución de problemas.

1.3 Reflexiona sobre el proceso de resolución de problemas: revisa las operaciones ut lizadas, las unidades de los resultados, comprueba e interpreta las soluciones en el contexto de la situación, busca otras formas de resolución, etc.

1.4 Realiza estimaciones y elabora conjeturas sobre los resultados de los problemas a resolver, contrastando su validez y valorando su utilidad y eficacia.

1.5 Identifica e interpreta datos y mensajes de textos numéricos sencillos de la vida cotidiana (facturas, folletos publicitarios, rebajas...)

2.1 Comunica verbalmente de forma razonada de la realidad. el proceso seguido en la resolución de un problema de matemáticas o en contextos 


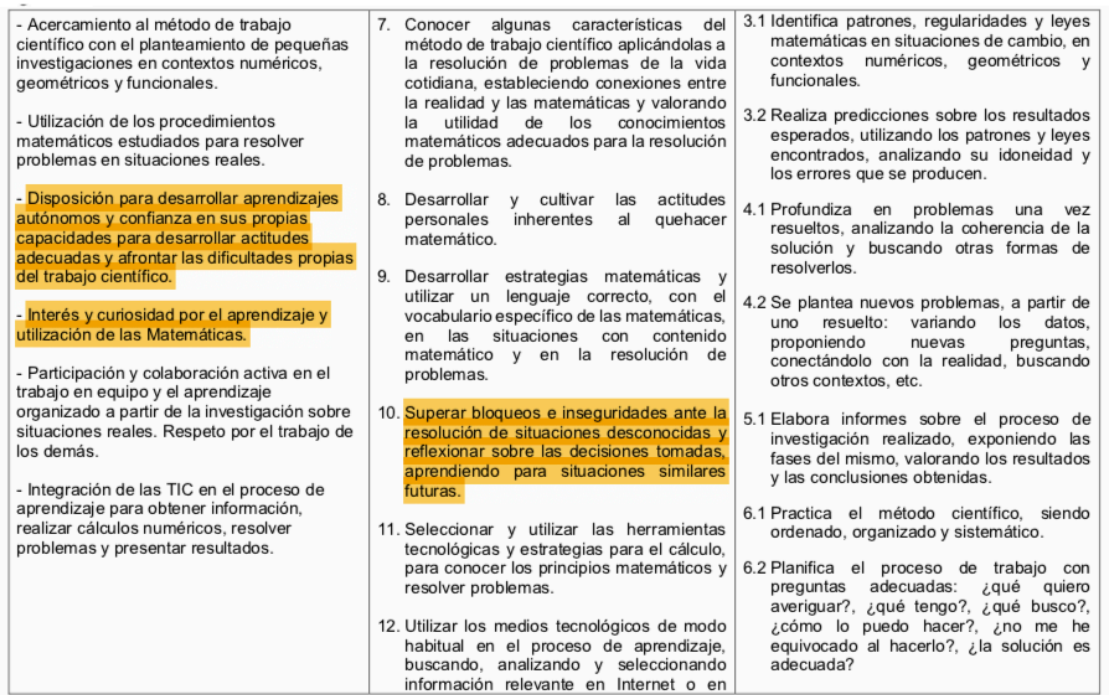

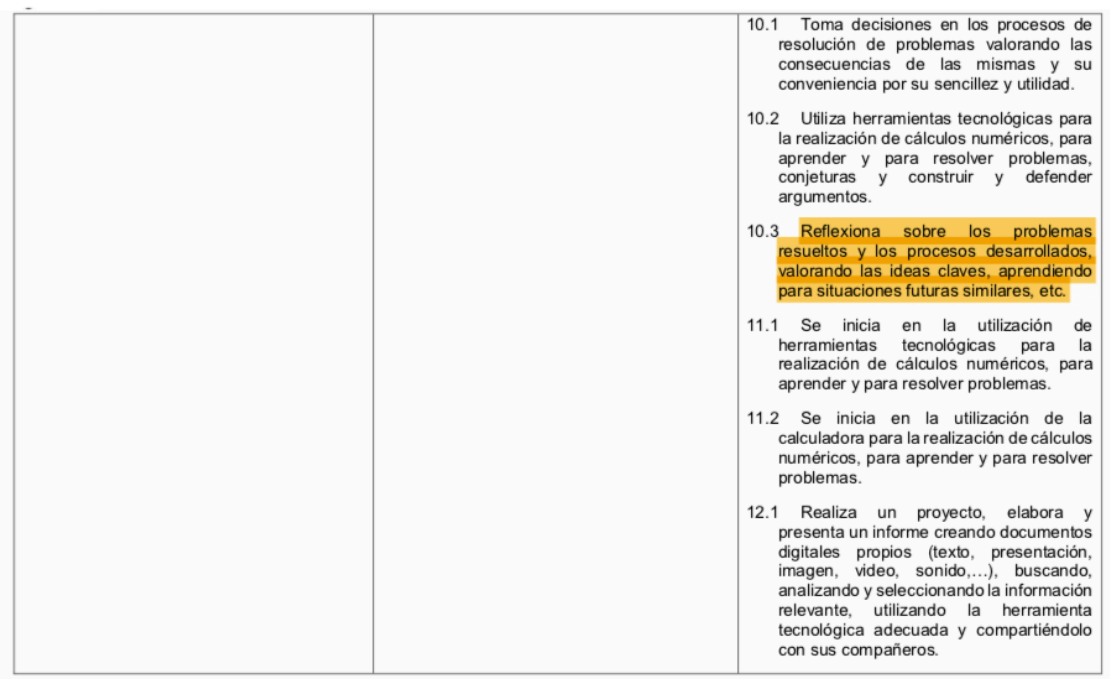




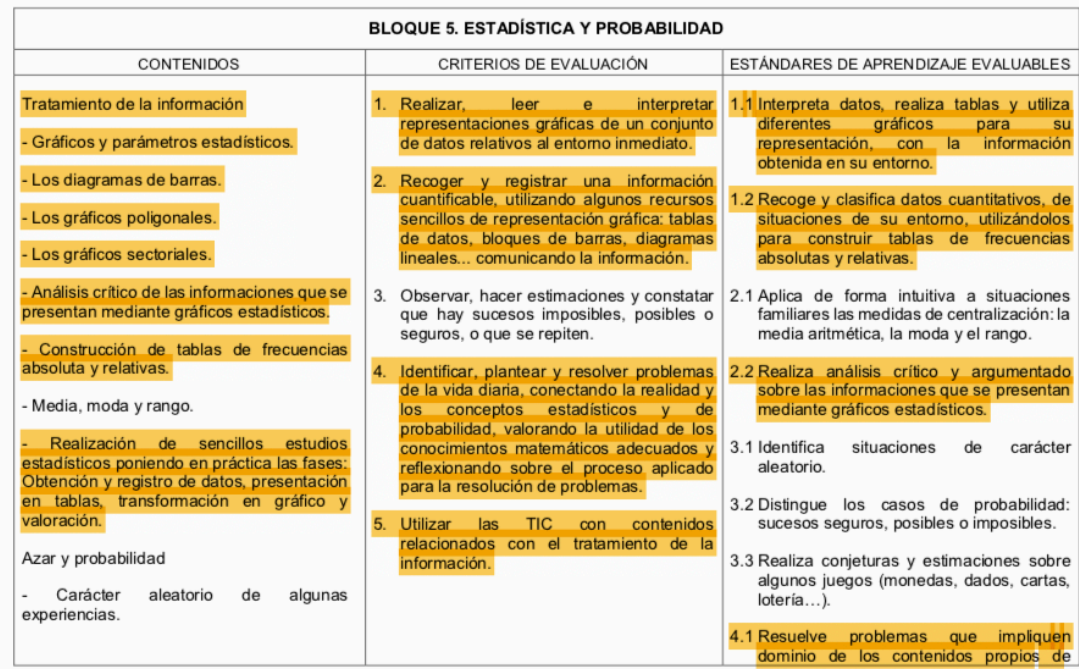

\begin{tabular}{|c|c|}
\hline $\begin{array}{l}\text { - Cálculo de probabilidades. } \\
\text { - Suceso seguro, posible o imposible. }\end{array}$ & $\begin{array}{l}\text { estadistica y probabilidad, utilizando } \\
\text { estrategias heurísticas, de razonamiento } \\
\text { (clasificación, reconocimiento de las } \\
\text { relaciones, uso de contraejemplos), } \\
\text { creando conjeturas, construyendo, } \\
\text { argumentando, y tomando decisiones, } \\
\text { valorando las consecuencias de las } \\
\text { mismas y la conveniencia de su utilización. } \\
\text { 4.2 Reflexiona sobre el proceso de resolución } \\
\text { de problemas: revisando las operaciones } \\
\text { utilizadas, las unidades de los resultados, } \\
\text { comprobando e interpretando las } \\
\text { soluciones en el contexto, proponiendo } \\
\text { otras formas de resolverlo. } \\
\text { 5.1 Usa las TIC con contenidos relacionados } \\
\text { con el tratamiento de la información. }\end{array}$ \\
\hline
\end{tabular}


SEXTO CURSO

\begin{tabular}{|c|c|c|}
\hline \multicolumn{3}{|c|}{ EDUCACIÓN PLÁSTICA } \\
\hline \multicolumn{3}{|c|}{ BLOQUE 1. EDUCACIÓN AUDIOVISUAL } \\
\hline CONTENIDOS & CRITERIOS DE EVALUACIÓN & ESTÁNDARES DE APRENDIZAJE EVALUABLES \\
\hline $\begin{array}{l}\text { - Establecimiento de un orden o pauta para } \\
\text { seguir el procedimiento de observación y } \\
\text { clasificación de nuevos lenguajes } \\
\text { artísticos. } \\
\text { - Preparación de documentos propios de la } \\
\text { comunicación artística como videoclips y } \\
\text { cortometrajes. } \\
\text { - Las TIC para el tratamiento de imágenes, } \\
\text { diseño y animación, y su empleo para la } \\
\text { dífusión de los trabajos elaborados. } \\
\text { - Realización de proyectos audiovisuales } \\
\text { empleando diferentes técnicas. } \\
\text { - La imagen en los medios y TIC. Análisis y } \\
\text { valoración de la intención comunicativa de } \\
\text { los nuevos códigos audiovisuales. Uso } \\
\text { responsable de las imágenes en los } \\
\text { medios informáticos. } \\
\text { - Uso de programas digitales de edición y } \\
\text { procesado de imagen, vídeo y texto. }\end{array}$ & $\begin{array}{l}\text { 1. Distinguir las diferencias fundamentales } \\
\text { entre las imágenes fijas y en movimiento } \\
\text { clasificándolas siguiendo patrones } \\
\text { aprendidos y expresando con un } \\
\text { vocabulario adecuado los elementos } \\
\text { propios del lenguaje plástico. } \\
\text { 2. Aproximarse a la lectura, análisis e } \\
\text { interpretación del arte y las imágenes fijas } \\
\text { y en movimiento en sus contextos } \\
\text { culturales e históricos, comprendiendo de } \\
\text { manera crítica su significado y función } \\
\text { social, siendo capaz de elaborar imágenes } \\
\text { nuevas y empleando diferentes técnicas, a } \\
\text { partir de los conocimientos adquiridos. } \\
\text { 3. Utilizar las TIC de manera responsable } \\
\text { para la búsqueda, creación y difusión de } \\
\text { imágenes fijas yen movimiento. }\end{array}$ & $\begin{array}{l}\text { 1.1 Reconoce las imágenes fijas y en } \\
\text { movimiento en su entorno y las clasifica. } \\
\text { 2.1. Analiza de manera sencilla y utilizando la } \\
\text { terminologia adecuada imágenes fijas } \\
\text { atendiendo al tamaño, formato, elementos } \\
\text { básicos (puntos, rectas, planos, colores, } \\
\text { iluminación, función...). } \\
\text { 2.2. Conoce la evolución de la fotografia del } \\
\text { blanco y negro al color, de la fotografía en } \\
\text { papel a la digital, y valora las posibilidades } \\
\text { que ha proporcionado la tecnología. } \\
\text { 2.3.Reconoce los diferentes temas de la } \\
\text { fotografia. } \\
\text { 2.4. Realiza fotografías, utilizando medios } \\
\text { tecnológicos, analizando posteriormente si } \\
\text { el encuadre es el más adecuado al } \\
\text { propósito inicial. } \\
\text { 2.5.Elabora carteles con diversas } \\
\text { informaciones considerando los conceptos } \\
\text { de tamaño, equilibrio, proporción y color, y } \\
\text { añadiendo textos utilizando la tipografia } \\
\text { más adecuada a su función. }\end{array}$ \\
\hline
\end{tabular}

\section{Boletín Oficial de Castilla y León}

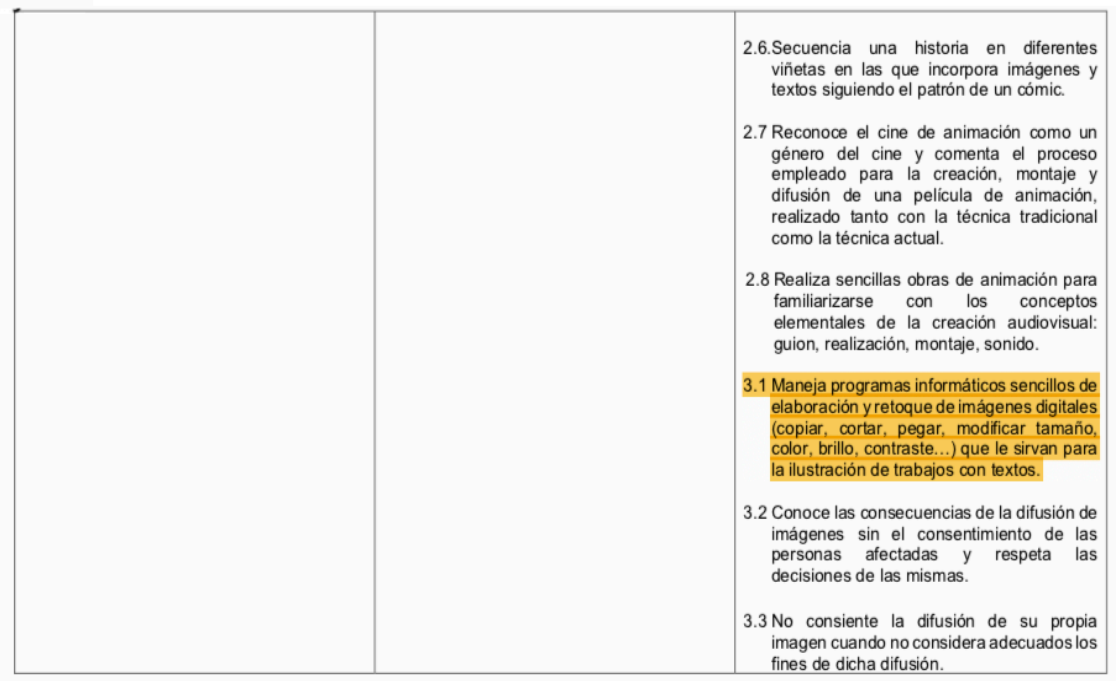


Boletín Oficial de Castilla y León

B(ு)

it: Lunes, 25 de julio de 2016 Pág. 34581

BLOQUE 2. EXPRESIÓN ARTÍSTICA

\begin{tabular}{|c|c|c|}
\hline \multicolumn{3}{|c|}{ BLOQUE 2. EXPRESIÓN ARTÍSTICA } \\
\hline CONTENIDOS & CRITERIOS DE EVALUACIÓN & ESTÁNDARES DE APRENDIZAJE EVALUABLES \\
\hline $\begin{array}{l}\text { - Vocabulario de términos referidos a } \\
\text { materiales, instrumentos o aspectos de la } \\
\text { creación artística. Utilización adecuada en }\end{array}$ & $\begin{array}{l}\text { 1. Identificar el entorno próximo y el } \\
\text { imaginario, explicando, con un lenguaje } \\
\text { plástico adecuado, sus características. }\end{array}$ & $\begin{array}{l}1.1 \text { Utiliza el punto, la linea y el plano al } \\
\text { representar el entorno próximo y el } \\
\text { imaginario. }\end{array}$ \\
\hline $\begin{array}{l}\text { los comentarios orales y escritos. Análisis } \\
\text { de obras y técnicas. } \\
\text { - El dibujo de representación. Pintores y } \\
\text { temas. }\end{array}$ & $\begin{array}{l}\text { 2. Representar de forma personal ideas, } \\
\text { acciones y situaciones valiéndose de los } \\
\text { elementos que configuran el lenguaje } \\
\text { visual. }\end{array}$ & $\begin{array}{l}2.1 \text { Distingue y explica las características del } \\
\text { color, en cuanto a su luminosidad, tono y } \\
\text { saturación, aplicándolas con un propósito } \\
\text { concreto en sus producciones. }\end{array}$ \\
\hline $\begin{array}{l}\text { - Interacción de propuestas audiovisuales } \\
\text { con otras formas de expresión artística con } \\
\text { objeto de desarrollar un proyecto. }\end{array}$ & $\begin{array}{l}\text { 3. Realizar producciones plásticas siguiendo } \\
\text { pautas elementales del proceso creativo, } \\
\text { experimentando, reconociendo y } \\
\text { diferenciando la expresividad de los }\end{array}$ & $\begin{array}{l}\text { 2.2 Clasifica y ordena los colores primarios } \\
\text { (magenta, cyan y amarillo) y secundarios } \\
\text { (verde, violeta y rojo) en el circulo cromático } \\
\text { y los utiliza con sentido en sus obras. }\end{array}$ \\
\hline $\begin{array}{l}\text { Aplicación de estrategias y creativas, } \\
\text { responsabilidad en el trabajo cooperativo, } \\
\text { establecimiento de momentos de revisión, } \\
\text { respeto a las aportaciones de los demás y }\end{array}$ & $\begin{array}{l}\text { diferentes materiales y técnicas pictóricas y } \\
\text { eligiendo las más adecuadas para la } \\
\text { realización de la obra planeada, } \\
\text { disfrutando tanto del proceso de } \\
\text { elaboración como del resultado final. }\end{array}$ & $\begin{array}{l}2.3 \text { Conoce la simbología de los colores frios y } \\
\text { cálidos y aplica dichos conocimientos para } \\
\text { transmitir diferentes sensaciones en las } \\
\text { composiciones plásticas que realiza. }\end{array}$ \\
\hline $\begin{array}{l}\text { resolución de las discrepancias con } \\
\text { argumentos. } \\
\text { - Criterios para el desarrollo de un } \\
\text { pensamiento estético en la comunicación }\end{array}$ & $\begin{array}{l}\text { 4. Utilizar recursos bibliográficos, de los } \\
\text { medios de comunicación y de Internet para } \\
\text { obtener información que le sirva para } \\
\text { planificar y organizar los procesos }\end{array}$ & $\begin{array}{l}\text { 2.4 Analiza y compara las texturas naturales y } \\
\text { artificiales, así como las texturas visuales y } \\
\text { táctiles siendo capaz de realizar trabajos } \\
\text { artísticos utilizando estos conocimientos. }\end{array}$ \\
\hline $\begin{array}{l}\text { - La representación de las formas en el } \\
\text { espacio. Comparación en diferentes áreas } \\
\text { o ámbitos. }\end{array}$ & $\begin{array}{l}\text { creativos, asi como para conocer e } \\
\text { intercambiar informaciones con otros } \\
\text { alumnos. }\end{array}$ & $\begin{array}{l}2.5 \text { Organiza el espacio de sus producciones } \\
\text { bidimensionales utilizando conceptos } \\
\text { básicos de composición, equilibrio y } \\
\text { proporción. }\end{array}$ \\
\hline $\begin{array}{l}\text { - La textura. Búsqueda sensorial de texturas } \\
\text { naturales y artificiales y de las cualidades }\end{array}$ & $\begin{array}{l}\text { tridimensionales con diferentes materiales, } \\
\text { recursos y técnicas. }\end{array}$ & $\begin{array}{l}2.6 \text { Distingue el tema o género de obras } \\
\text { plásticas. }\end{array}$ \\
\hline $\begin{array}{l}\text { y posibilidades de materiales orgánicos e } \\
\text { inorgánicos. Clasificación de texturas y } \\
\text { tonalidades para caracterizar objetos e }\end{array}$ & $\begin{array}{l}\text { 6. Conocer las manifestaciones artisticas más } \\
\text { significativas que forman parte del } \\
\text { patrimonio artistico y cultural, adquiriendo }\end{array}$ & $\begin{array}{l}\text { 3.1. Utiliza las técnicas dibujísticas y/o } \\
\text { pictóricas más adecuadas para sus } \\
\text { creaciones, manejando los materiales e }\end{array}$ \\
\hline
\end{tabular}


Anexo 5.3. Ejemplos de cuaderno de campo completados pertenecientes a cada uno de los prototipos
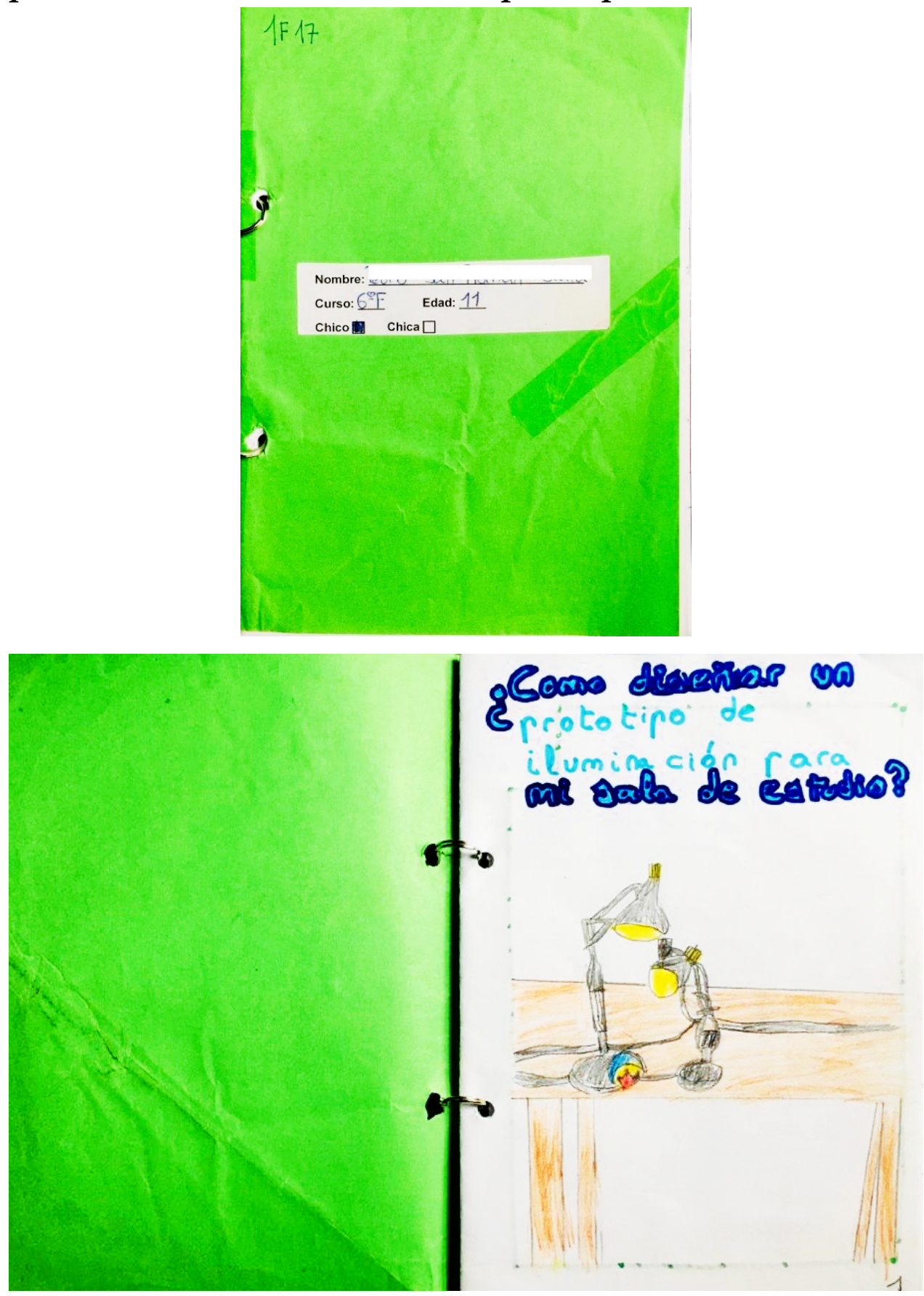


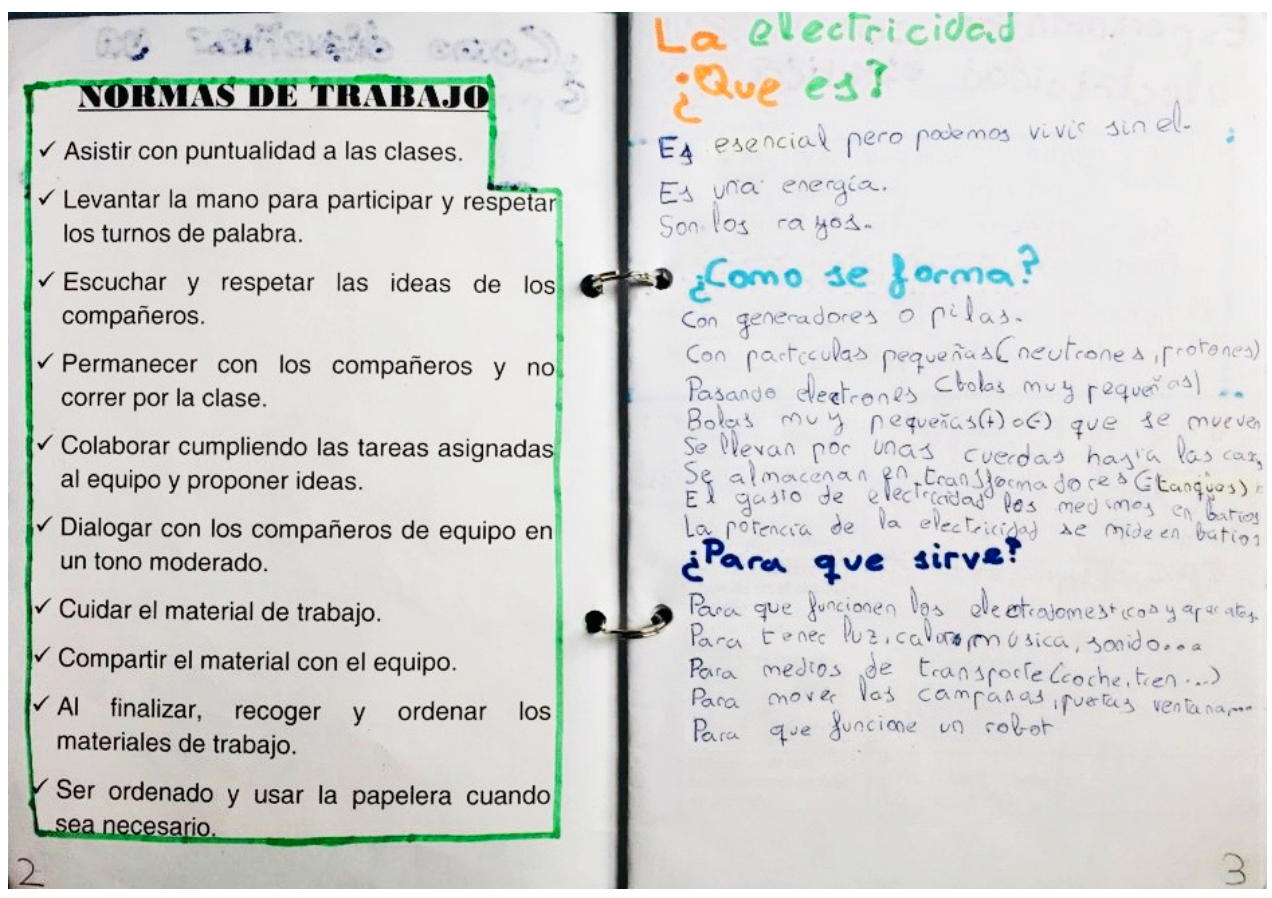

\section{Experimentos con electricidad estatila}

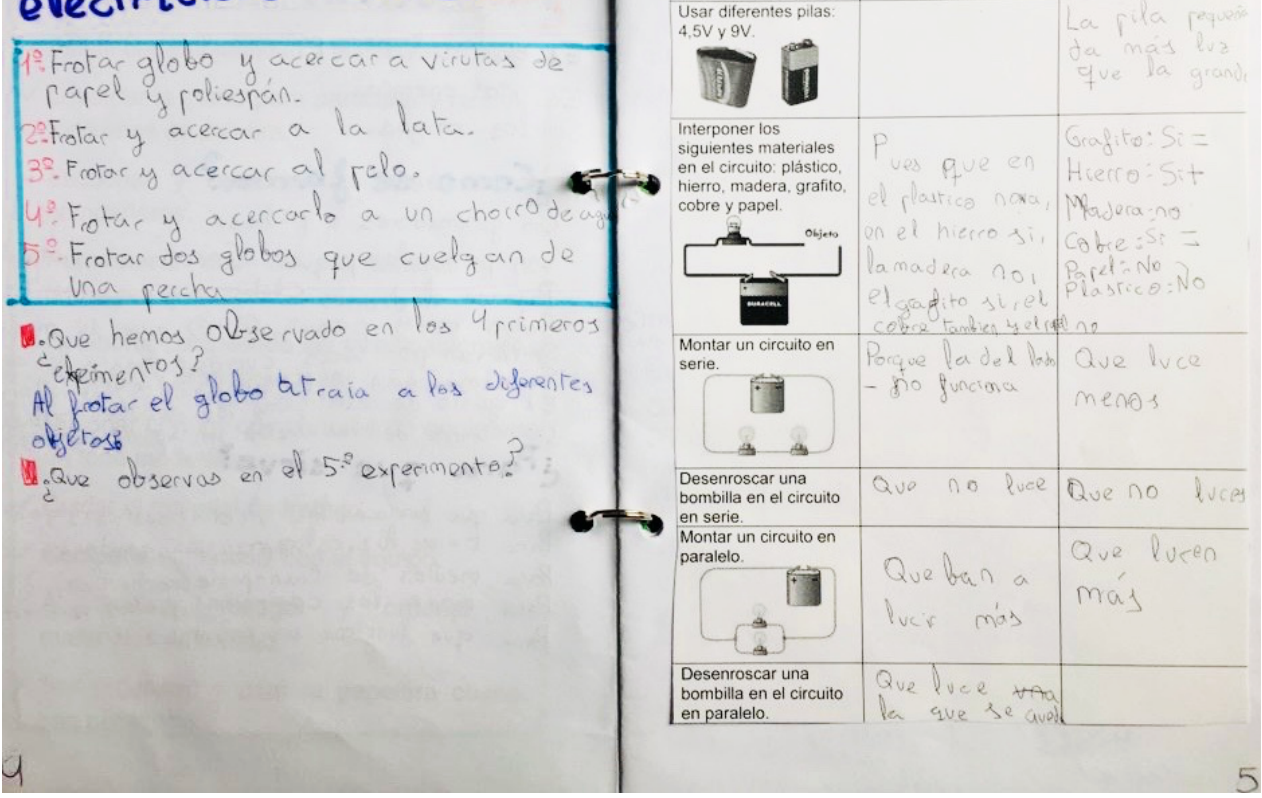




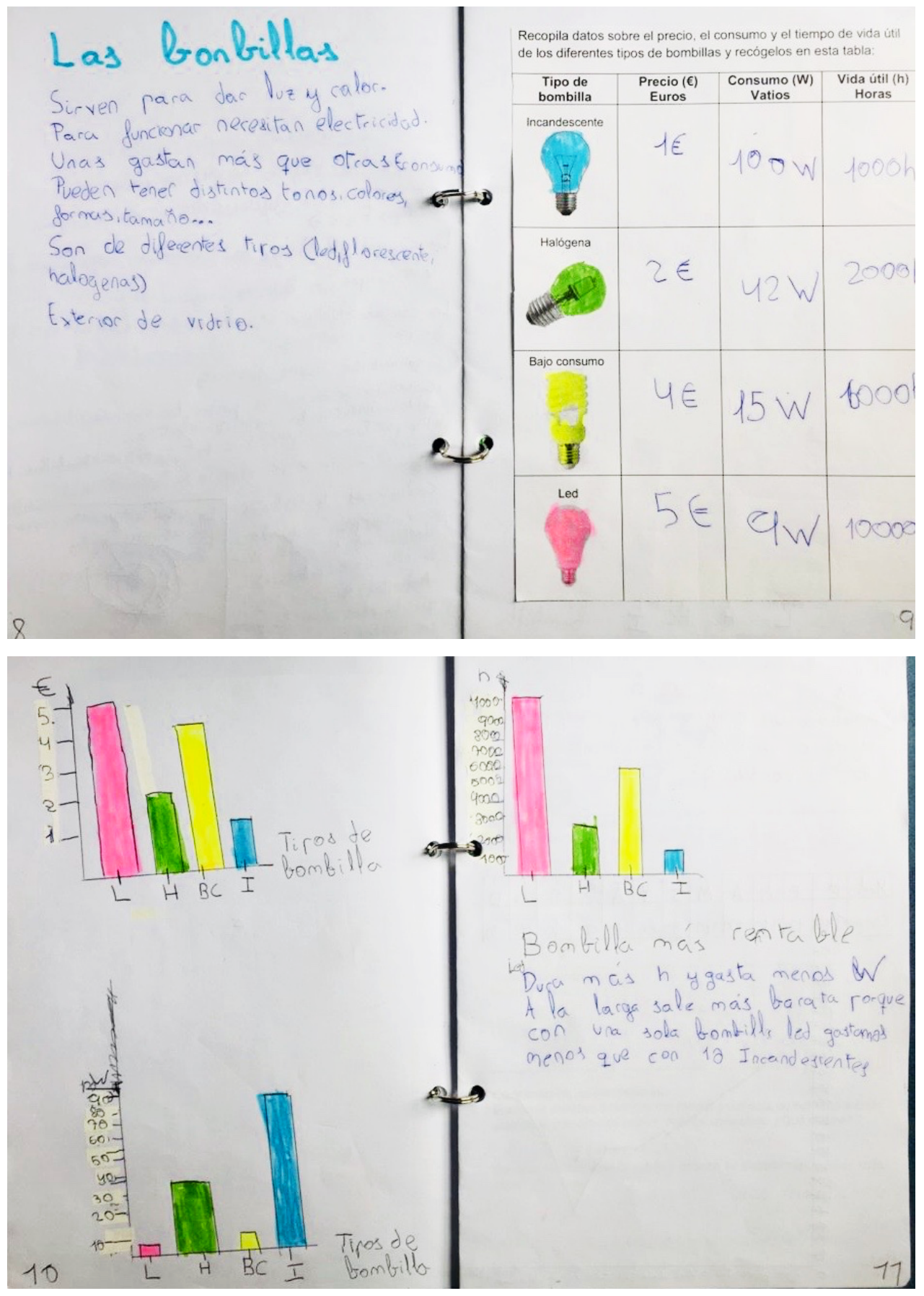



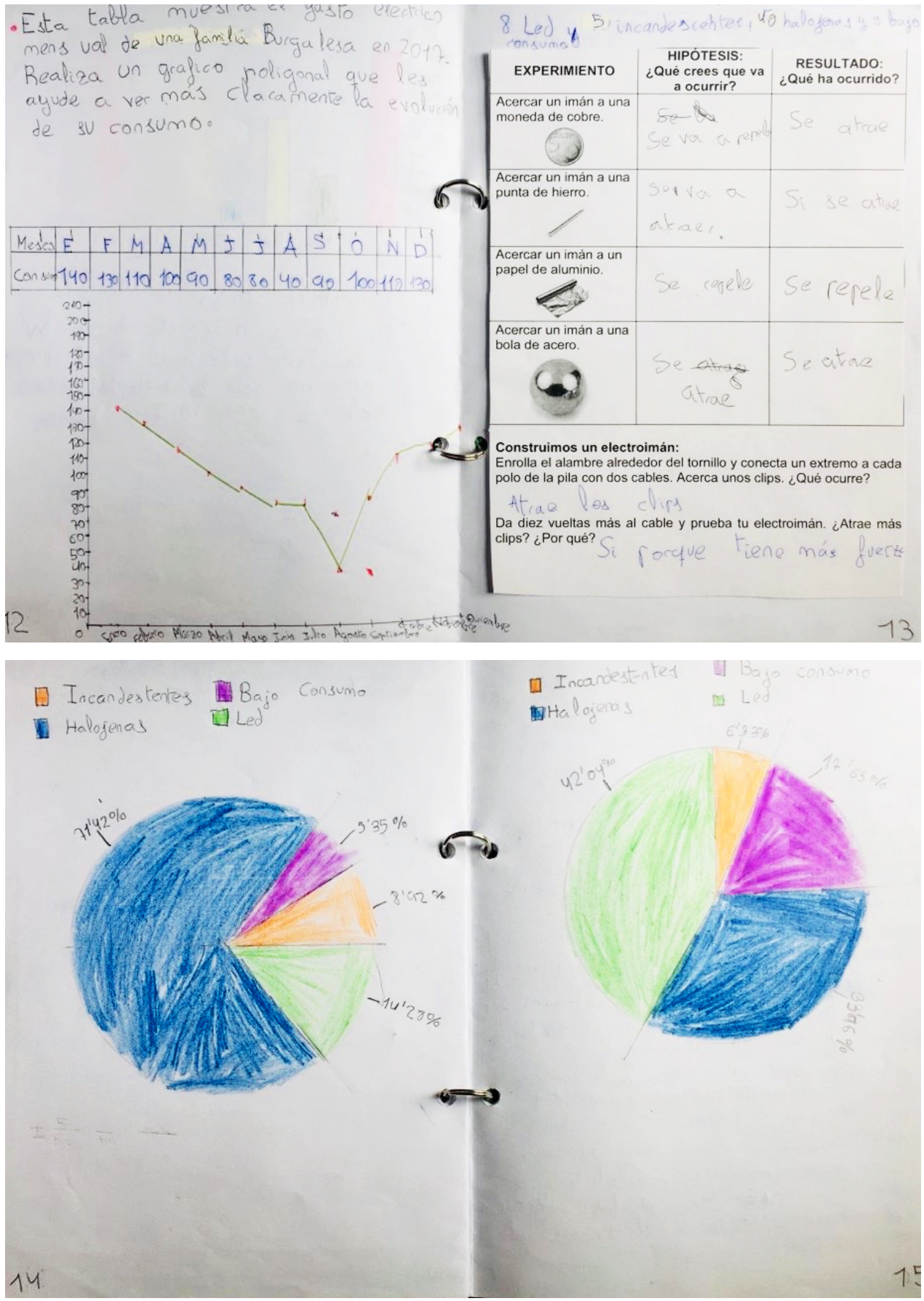


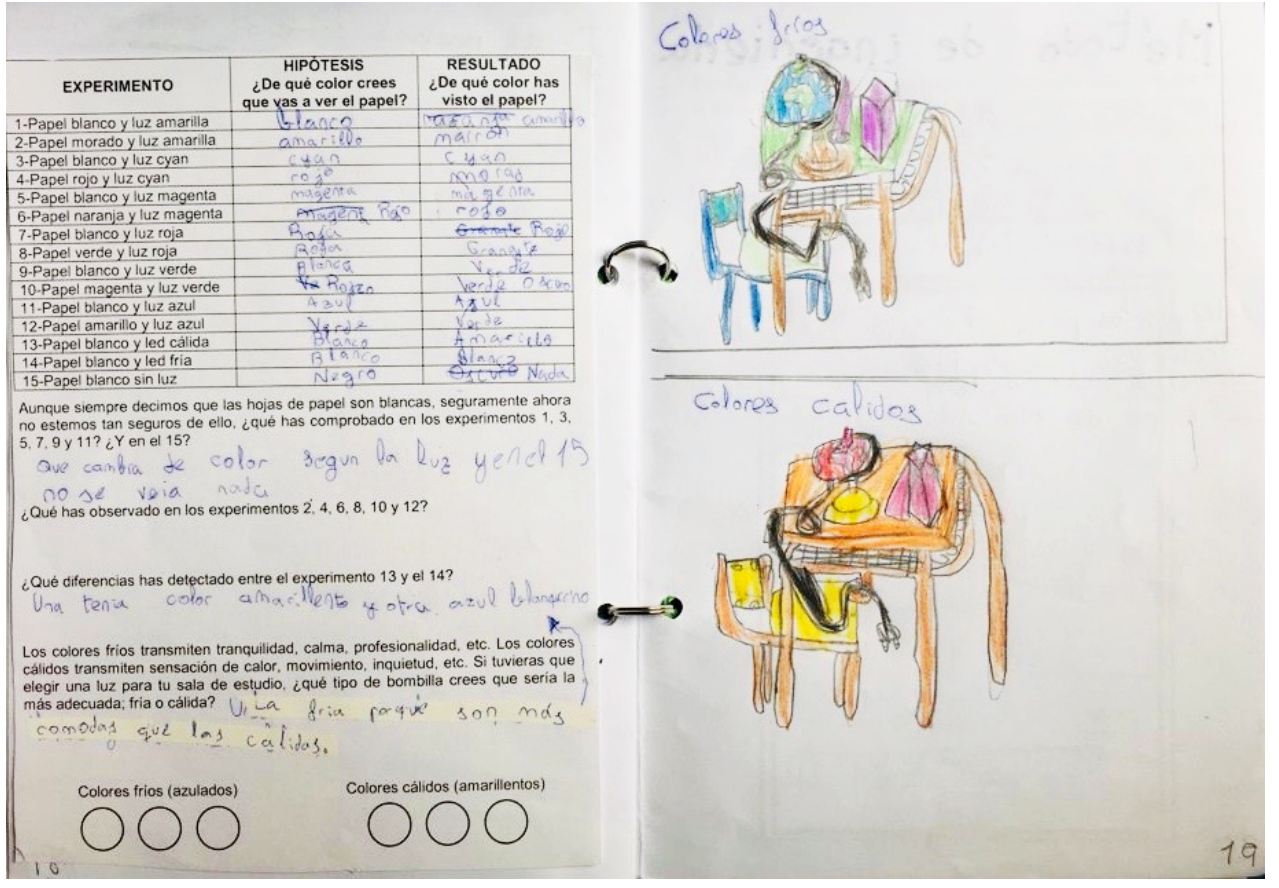

\section{Método de ingeniería}

- Fncionaría con elécticidad.

- Lo construiremos con un circuito

- Usaremas bombillas led.

- Urilizaremos led fria.

- Requisitos rara el diseño del proin

- Presupuesto márino: 17 E

- Consuma maximo:36 W

- Tiempo de vida ctil:-1 año
Disena con tu equipo un prototipo de iluminación que se ajuste tanto a los requisitos anteriores como a las caracteristicas de iluminación de la siguiente habitación. Como minimo debéis incorporar una cama, una mesa de estudio y una silla.

Dibuja el prototipo de iluminación que has consensuado con tu equipo teniendo en cuenta los simbolos y la simbología del color de las bombillas elegidas.
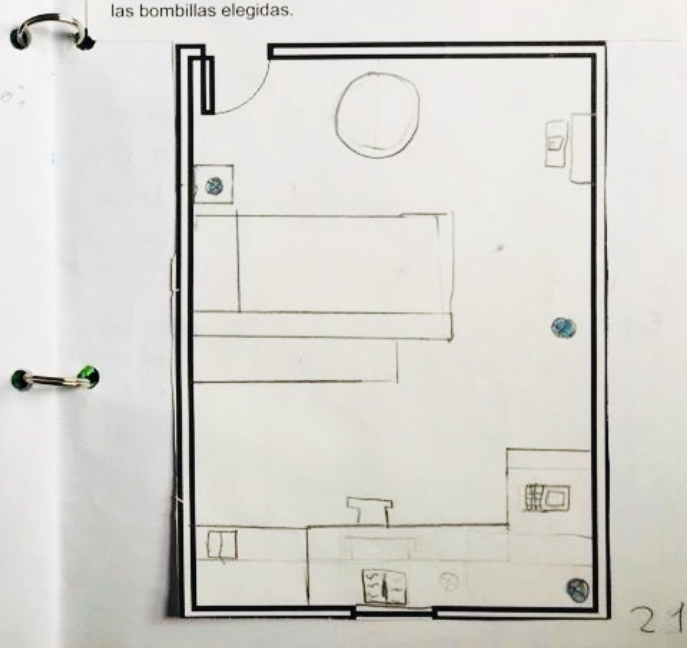
Hemos dividido la habitacion for un tabique

de modo que un lado lo utilizaremos

raca estudiai $y$ el otro raca el ocio, hemes

colocato tres luces led frias, con estas no

nos rasamos del resupuesto quera de $17 \mathrm{e}$

y no nos pasams de los batios que eras

36. Escogrimes las Ded frias rorque te can =

menos la vista.

La mesa de estudio la hemos calocado al

lado de la ventana y en L, con un plexe

led en $\mathrm{Va}$ esquina, al lado tanten hemos

ruesto una estanteria con libros y enfrente

un armacio.

Enfrente del tabique hemos colo cado una led rara alunbrar los dos lados y otra é

la mesilla de noche al lado de la cana.

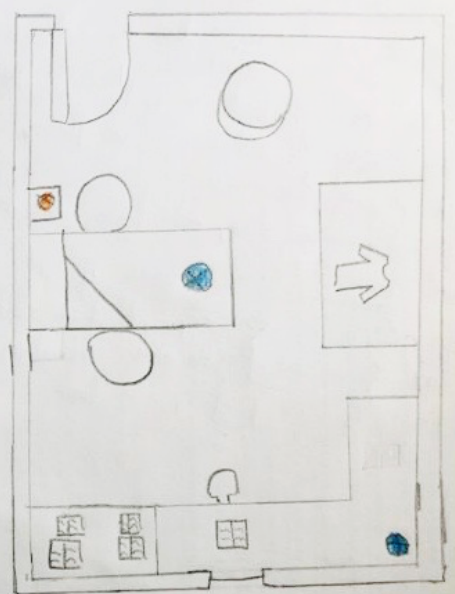

\section{2}

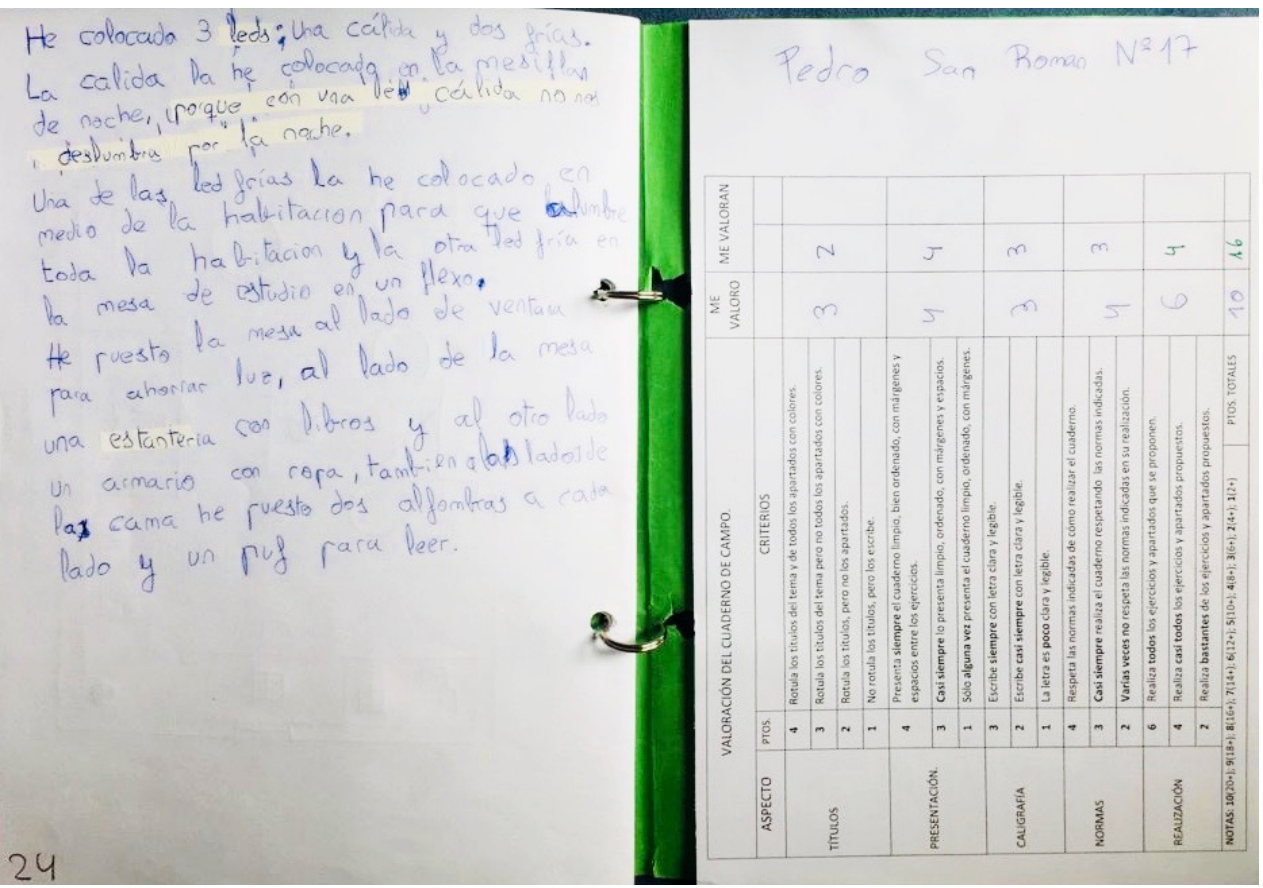



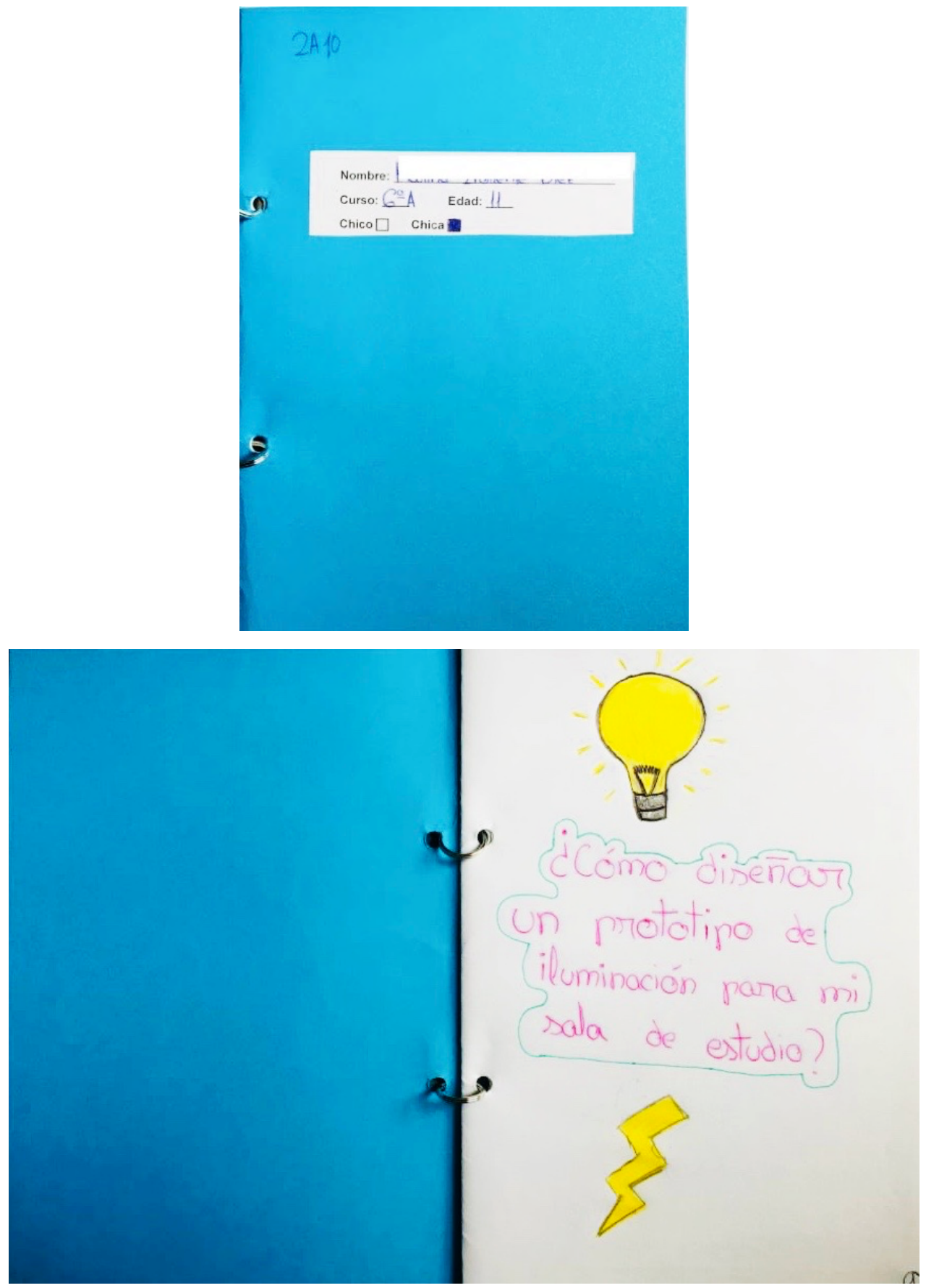


\section{YORMAS IDE THA IBA.JO}

$\checkmark$ Asistir con puntualidad a las clases

$\checkmark$ Levantar la mano para participar y respetar los turnos de palabra.

$\checkmark$ Escuchar y respetar las ideas de los compañeros

$\checkmark$ Permanecer en mi sitio de trabajo y no correr por la clase.

$\checkmark$ Colaborar cumpliendo las tareas asignadas al equipo y proponer ideas.

$\checkmark$ Dialogar con los compañeros de equipo en un tono moderado.

$\checkmark$ Cuidar el material de trabajo.

$\checkmark$ Compartir el material con el equipo.

$\checkmark$ Al finalizar, recoger y ordenar los materiales de trabajo.

$\checkmark$ Ser ordenado y usar la papelera cuando sea necesario.
IDIAS PRIVIAS SOBRI ELECTRICIDAD

Er un tige de enengía

- Se puede in reciclando (natunal)

Se puedo citlizan para das energía a apconatar

(liverescenter)

Se puede cthirar prona cangan energia

No se puede destruis, gerso si tranglonmes.

\section{EXPERIMENTOS CON ELECTRICIDAD ESTÁTICA}

1. Frotar un ablob y acencarlo al pelo

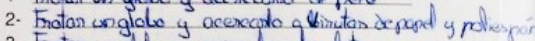

3- Fictar un globe y acercaslo a las latas.

4- Fratar un ghabo y acerraslo a un hroma de aqua

5. Frotar las glabas y colgarlos do vne periba.

¿Que has observado en los tres primeros experimentos?

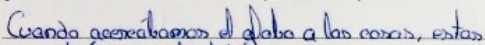
enan atraías pan d glabo

Los globas se repetian

\section{RESUMEN-ELECTRTCIDAD ESTÁTICA (rág 108 -109)}

- La dectricidad estáica se produce al frotor determinades objetos entre sí. Esta electricidad hace que digunos cuerpos se atraigan o se repelan

- Los dejetas son nonmalmente nectros : tienen tontas positi.

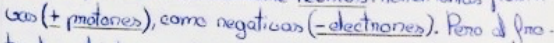
tar los objetos, pueden adquirior un exceso do cargas po sitivas en un material y cargas negatioas sobne la sunerficie ded otro.

- Los cuerpos que tienen el mismo ti po de carga eléctrica se repelen (exponimento de frotar dos glabos)

- Los cuerpos que tienen distintotino decarga eléctrica

se atraen (expenmento de froton glolo que derpues atroe trocitor de frinermito de frotar glolo que después atnoe nocitos de panel)
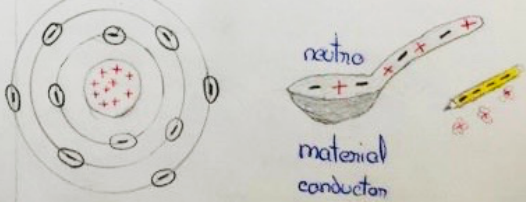


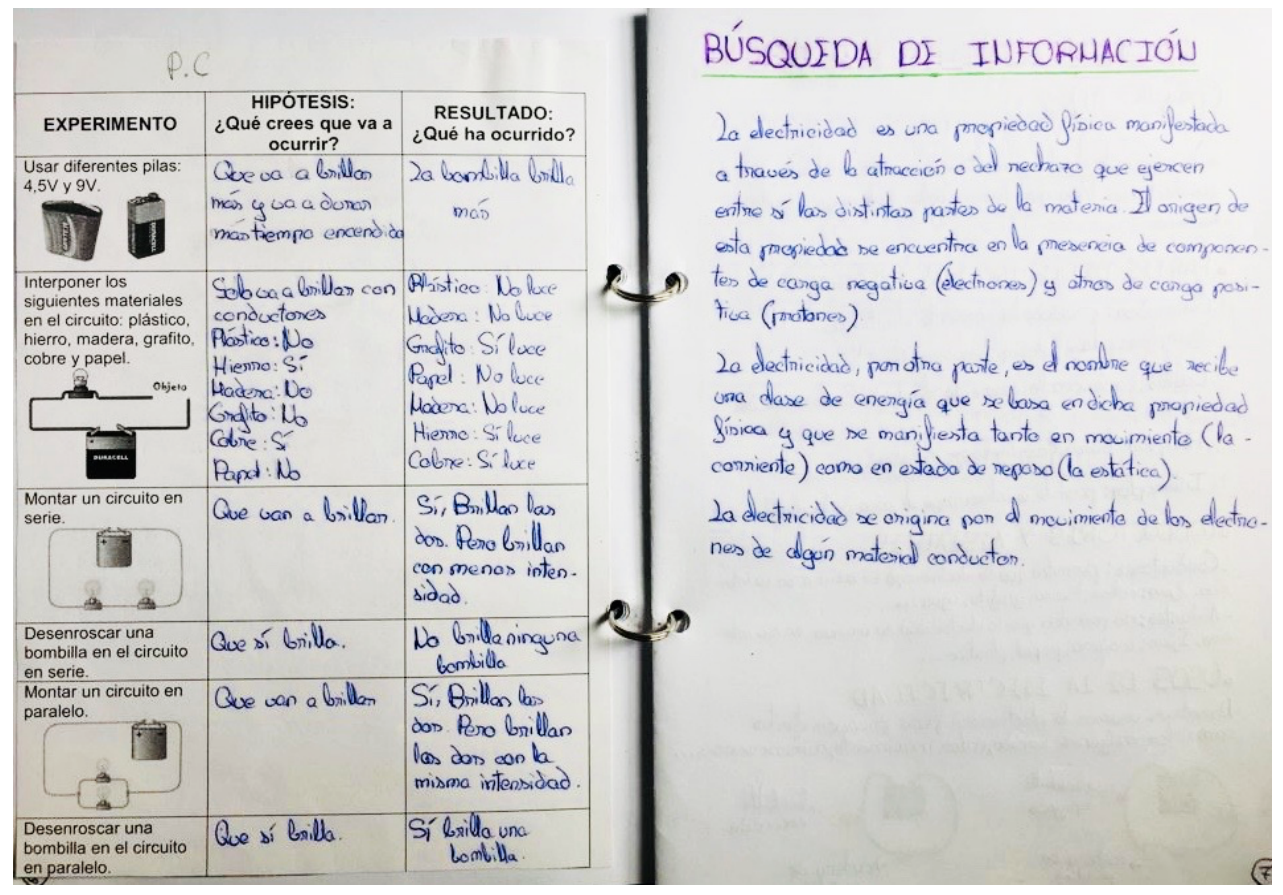

\section{RISUMEN CORRIEUTE ELÉCTRICA} (rág $110-111)$

- La corriente eléctricaes el movimiento continuo de cá. gas déctricas. Pra que courua debe haben un cincuto eléctrico.

- PARTIS DE UN CIRCUITO ELÉCTRTCO

1. Generadon: moduco la comiente eléctrica.

Ejomplos: pilas, baterias, disamos

2. Colles: conducen la coraiente eléctrica. Suelen ser de
colve.

3. Recenton: banbillas, timbres, motones...

4. Internupten: permite o interoumpe d paso de la electriciadac - COUDUCTORES Y AISLAUTIS

- Conductones: permiten que la dectricidad se mueva en su inte. ron. Fjem: cobre, thieanno, graflito, agua...

- Aion Entes sno permiten que la electrcidad se mueva en su inte. ron. Ljem: madera, papel, plástico..

- USOS DE $2 A$ ELECTRICTDAD

Nosotros usamos lo dectricidad pana muducin electar como: lur, inágenes sonido, cealon, movimiente, comunicaciones

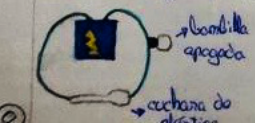

\section{IDEAS PRIVIAS SOBRF BONBILIAS}

- Hay de bajo consumo y de atto consumo

Se utitizan pana iluminan

Se colientan ¿Algunas o todas?

Algunas resisten más potencia que otras

- Hay de dguros colones y formas

Hay de diferentes tipos lez fluonescente - Se pueden fundin en función de la cantioad de vation

- Solo se excienden en un cirevite cerrade 


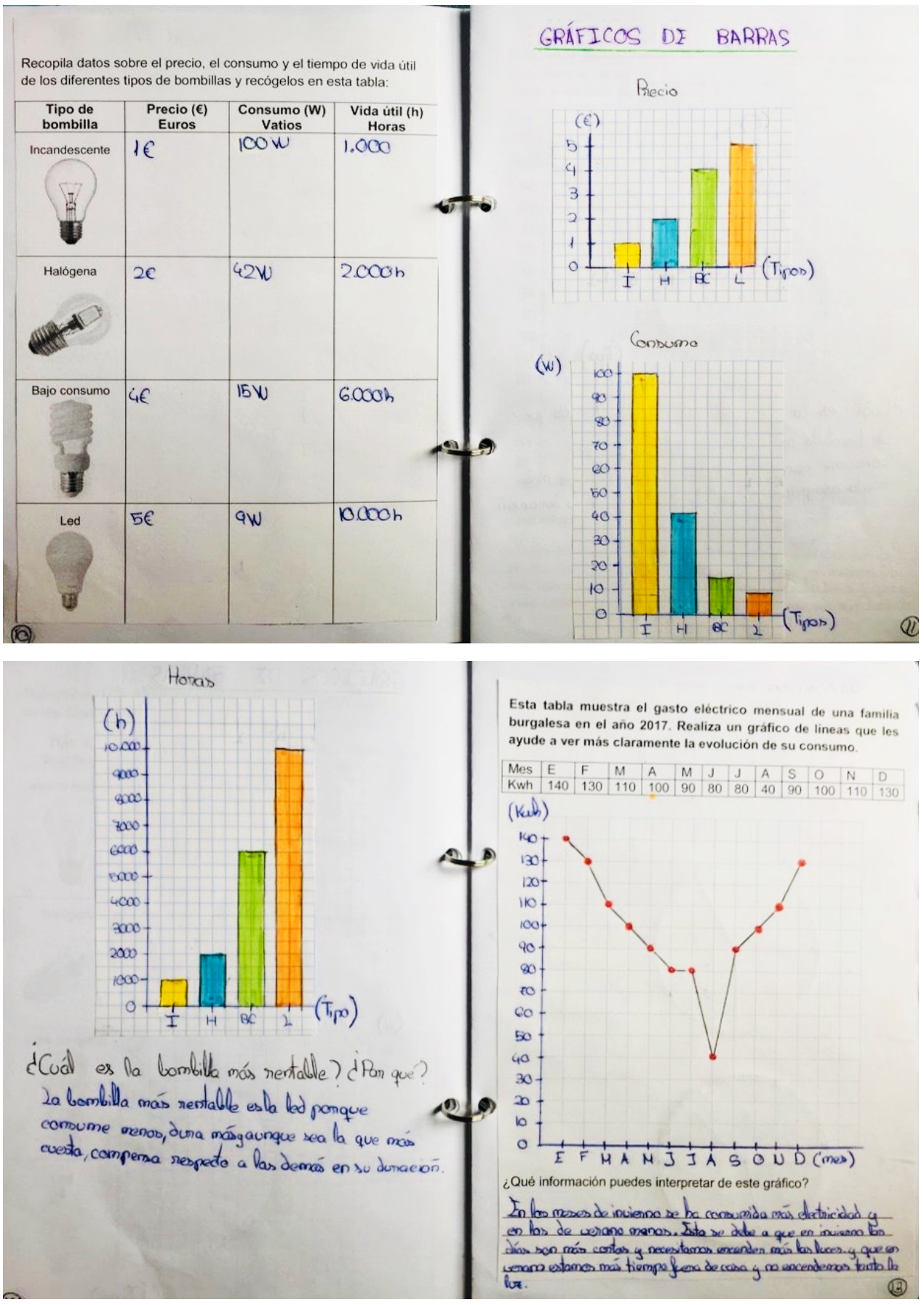




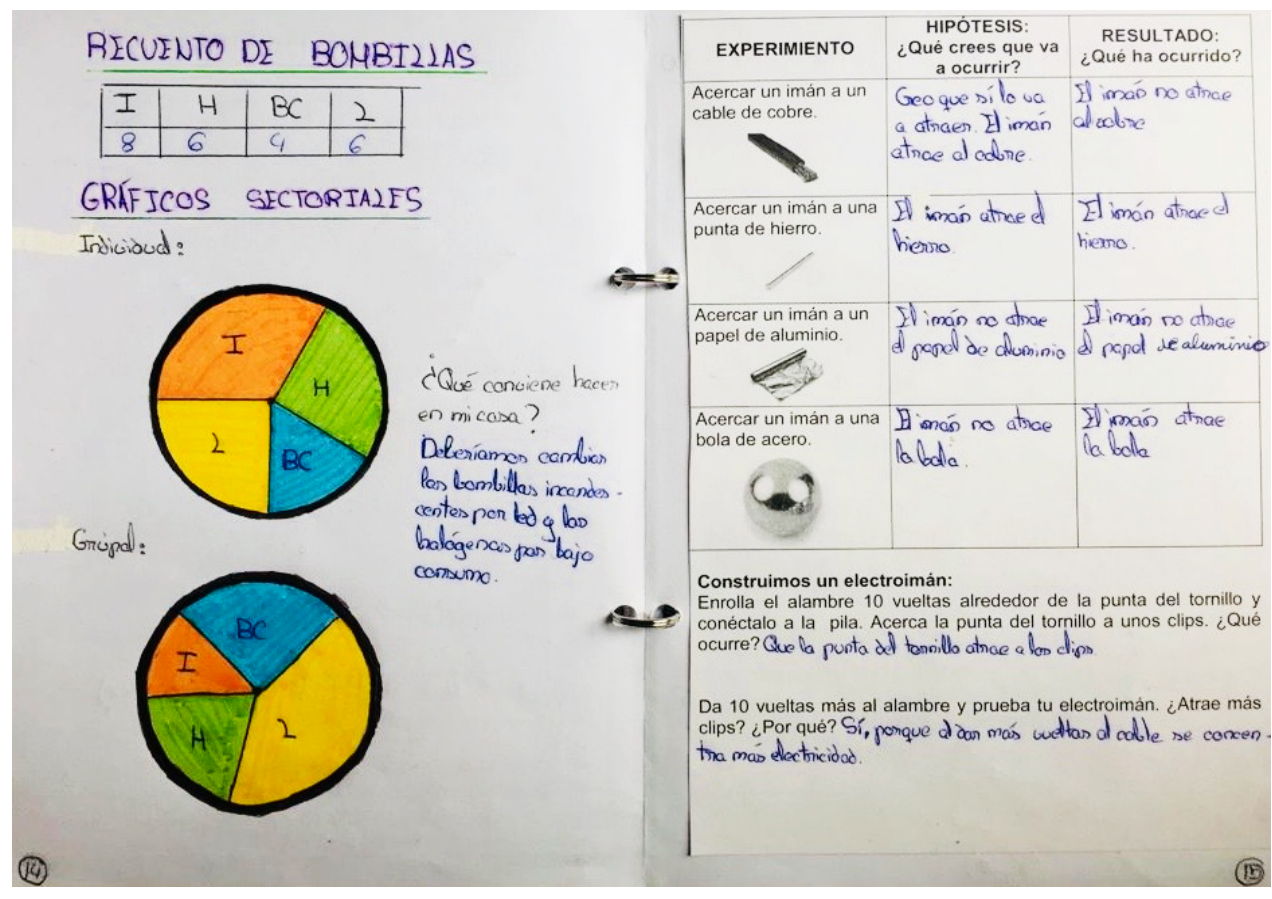

\section{RESUMEN MAGNETISHO Y ELICTROHAGNYTISHO}

- Il mognetismo es la masiedad de dyenos abjetes de atroer dhievro y douñ atro metal.

- Las imaness son las djectos que atroen el hierro. Los imanes guedenses naturdes, comola magretita y atififcides que han adquiride esta magriedad fratandolos con un imas o aghicando una consiente dectrica.

- Il campo megrético es el especic que rodea un imán.

- Losimanestienen dos polos. Si se acercan des jodos de mismotipo, estos se repelen y si los polos son de distinto tipo.

- La Terema se componta como un gran imán. La Terna tiene un un polo sur magrético siturido cenca del rodo sus grografice y un polo sur magretico situado cerca del polo nonte geografiea. tada que gira sobre un je. Fl farmado par una aguja iman. ido pere é polo sur un je. El polo note de la aguja es atra. magretico está muy magétice de la Tierra. Como ose pola sun jula nas señala ande a de polo nonte gecoradico, la brí- La señala dande está d neste.

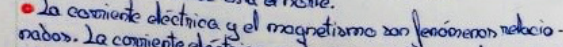

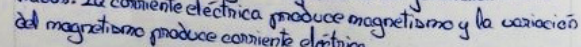

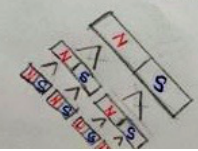

\section{IDIAS PRIYIAS SOBRE IL COLOR}

- Hay colones fries y calidas

- Bacmos rezeclar colones

In declar blance la luz nebota

Algunes alones gueden appresan emociones

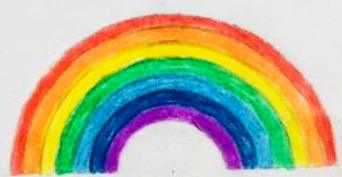




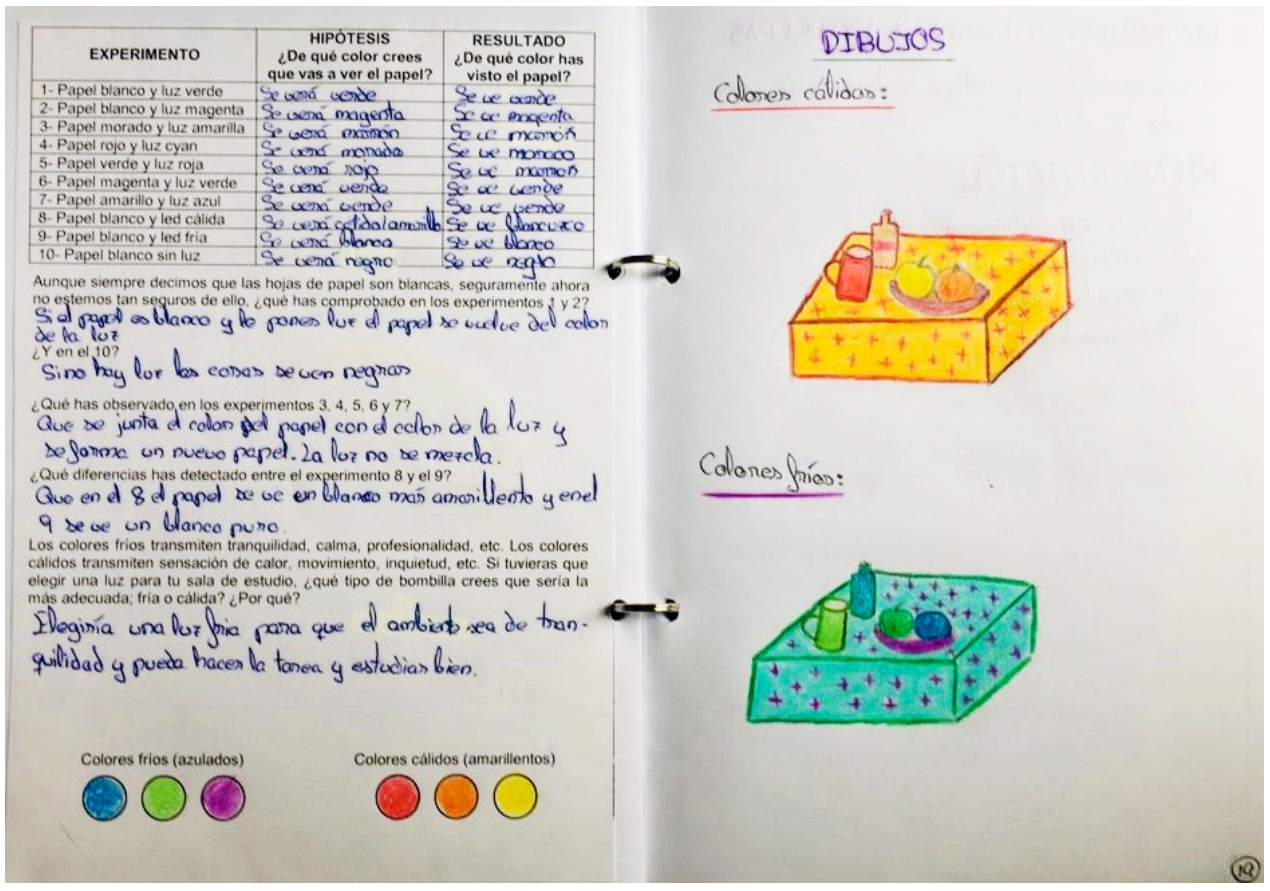

RECORDALOS II PROBIEMA PRIUCIPAS

¿Cómo diseñan un mentatipo de iluminación para mi sala de estudio?

\section{RECAPITUZACIÓN}

- Funciona con electricidad

- Le construinemas con un cincuito

- Usaremas bombillas led

- CHitizaremos leds frias
Diseña con tu equipo un prototipo de iluminación que se ajuste a los siguientes requisitos y a las caracteristicas de iluminación de la habitación que te ha tocado. Como minimo debéis incorporar una cama, una mesa de estudio y una silla.

Requisitos:

- Presupuesto máximo: $17 €$

- Consumo máximo de la habitación: 36W

- Tiempo de vida útil mínimo: 1 año

Una vez que hayảis trabajado aparte el boceto, dibuja el prototipo que has consensuado con tu equipo teniendo en cuenta la simbologia de las bombillas y su color. Fijate en la escala del plano y procura que el dibujo esté proporcionado.

Simbolo de la bombilla:

Color de una bombilla de luz fria: azul

Color de una bombilla de luz cálida: amarillo 


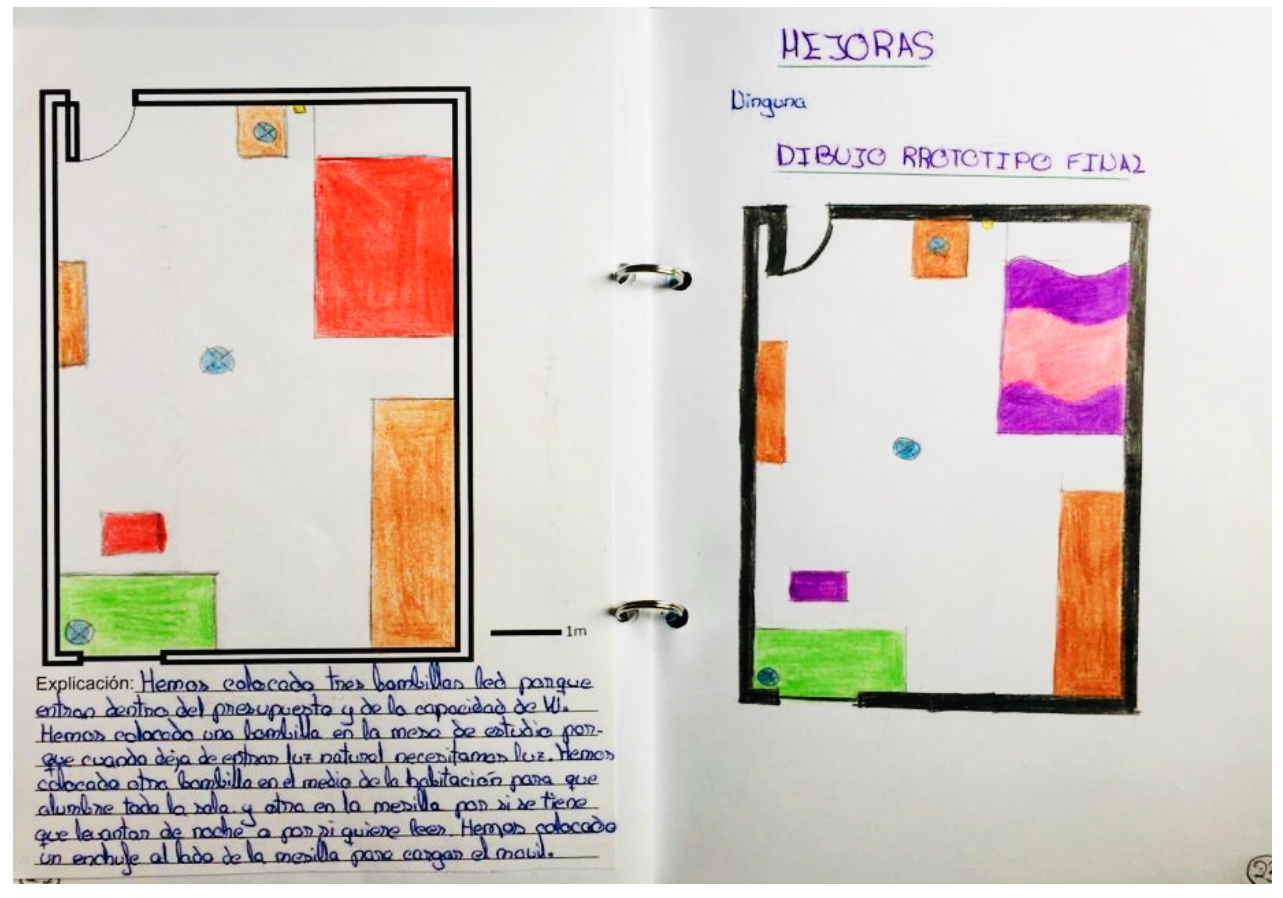




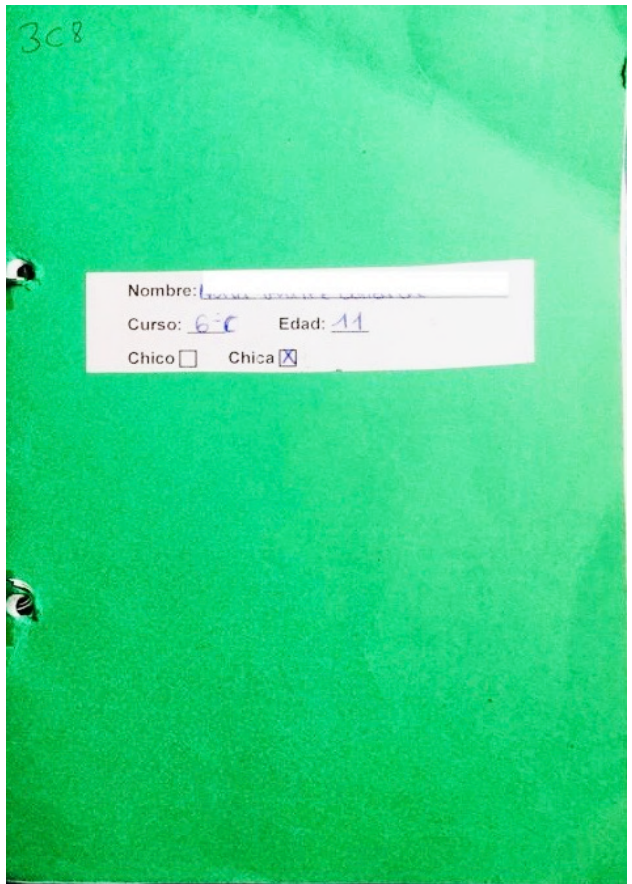

\section{VORMAS IDE THABAJO}

$\checkmark$ Asistir con puntualidad a las clases.

$\checkmark$ Levantar la mano para participar y respetar los turnos de palabra.

$\checkmark$ Escuchar y respetar las ideas de los compañeros.

$\checkmark$ Permanecer en mi sitio de trabajo y no correr por la clase.

$\checkmark$ Colaborar cumpliendo las tareas asignadas al equipo y proponer ideas.

$\checkmark$ Dialogar con los compañeros de equipo en un tono moderado.

$\checkmark$ Cuidar el material de trabajo.

$\checkmark$ Compartir el material con el equipo.

$\checkmark$ Al finalizar, recoger y ordenar los materiales de trabajo.

$\checkmark$ Ser ordenado y usar la papelera cuando sea necesario.

\section{DEAS FREVIAS SOBRE ElectriCIDAD}

- Es un tipo de energía

- Es renovable.

- No se crea ni se destru ye solo se transforma 1) - La utilizamos habitural mente en muchosaparates - Puede ser peligrosa

- No es materia 


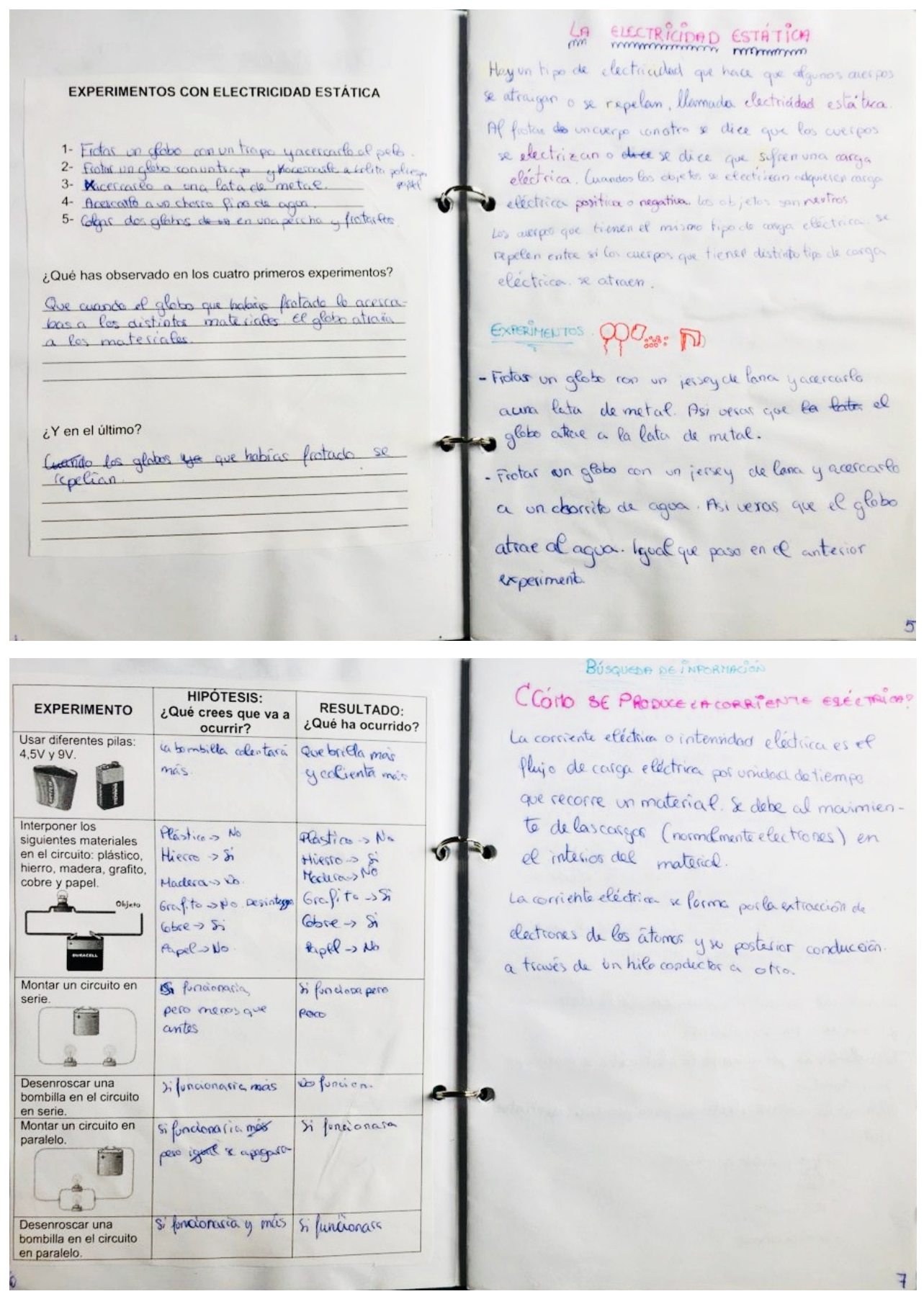




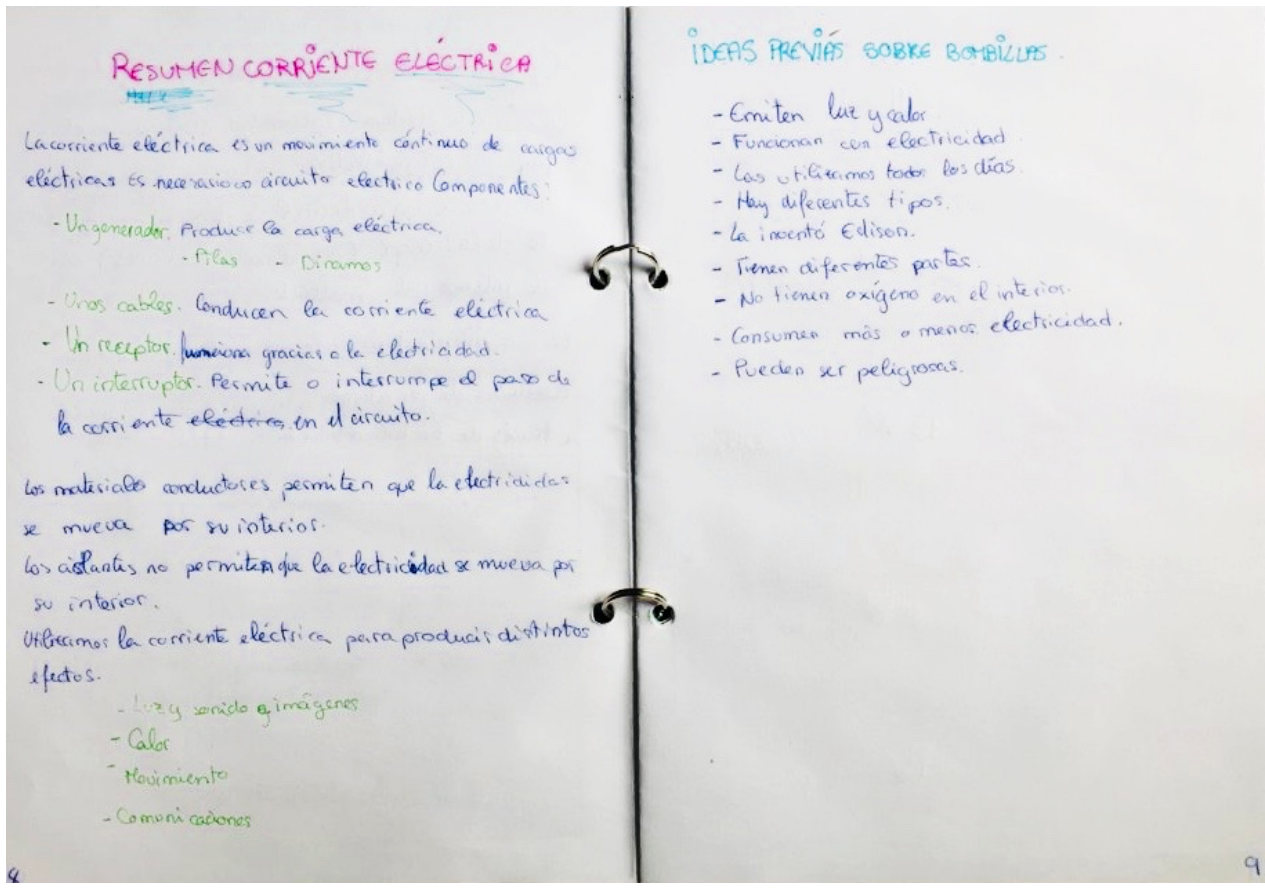

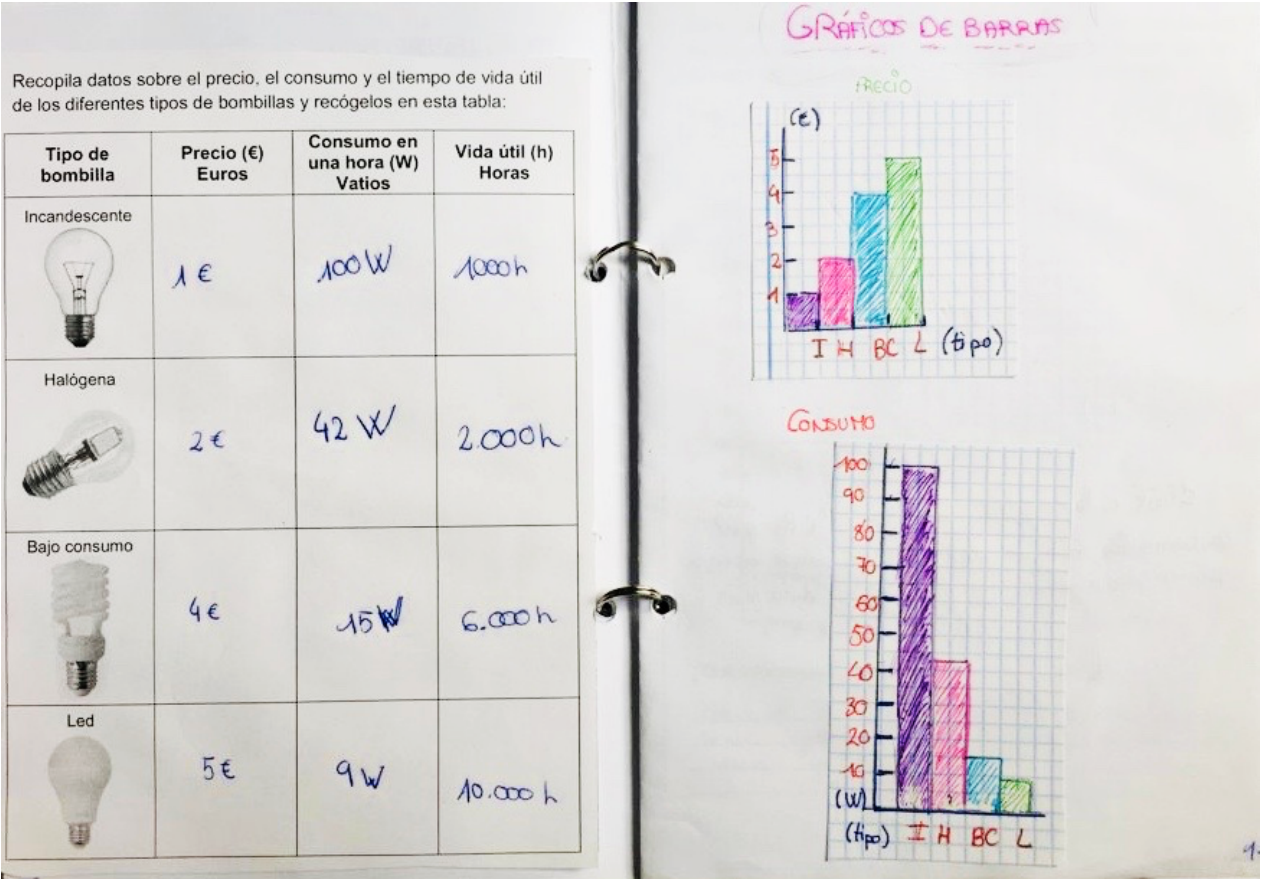




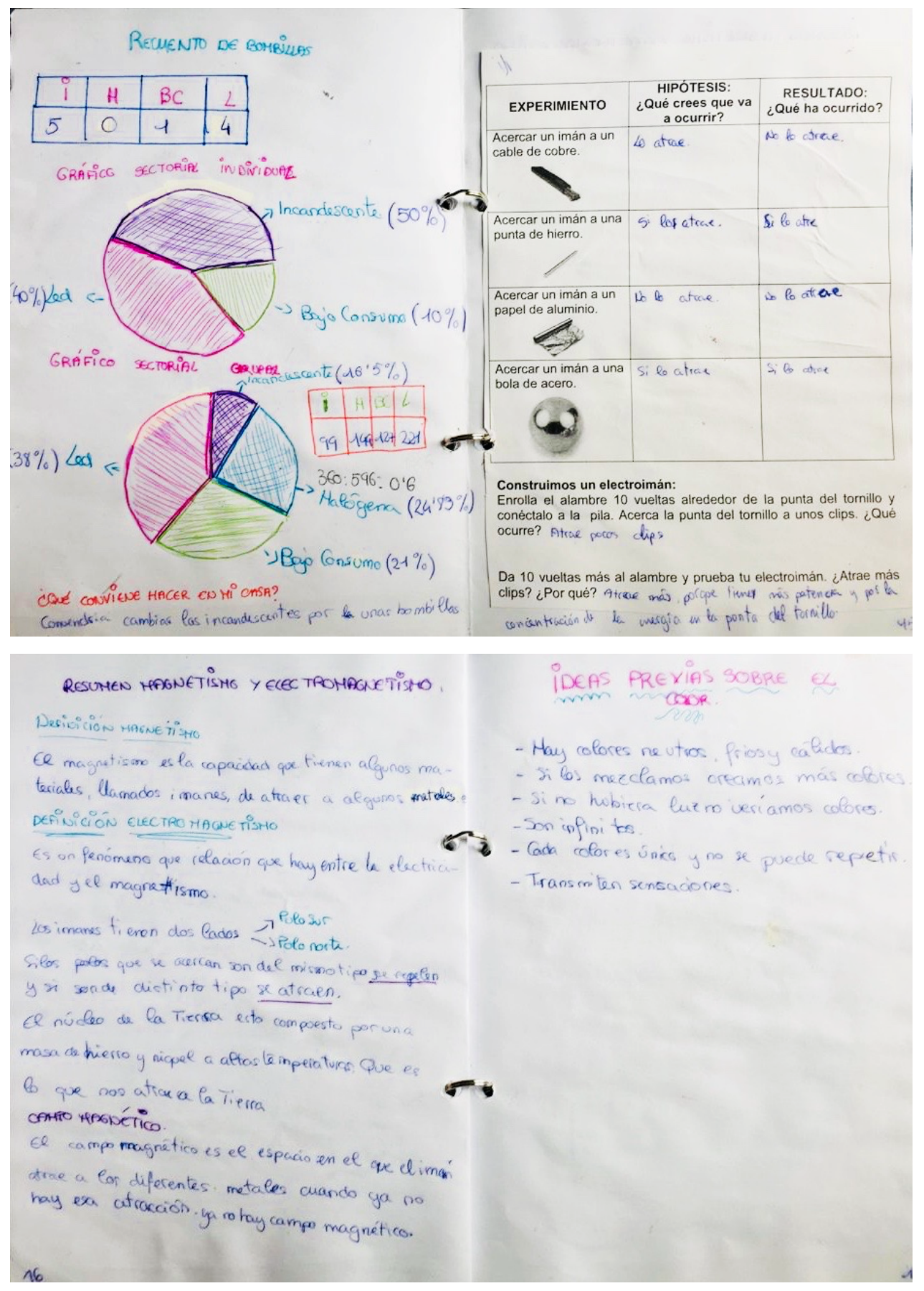



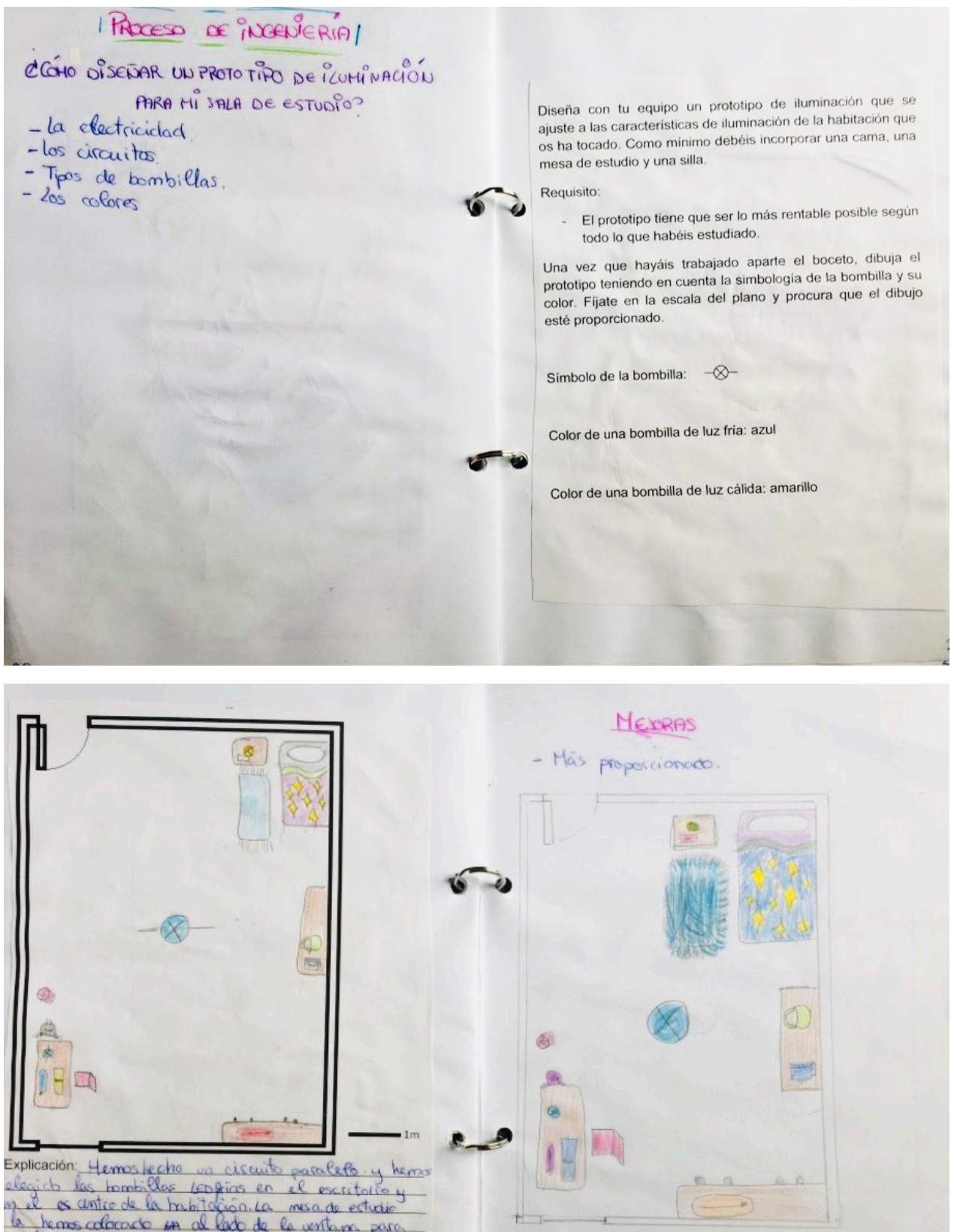

Explicación: Hemosiecho un ciscuito paralefo y hem elegiab les tombillas lesprias en el escritorion 7. el es untro de la maitagióni La mesa de estudic a hemos cofocado in al ledo de le veritam para disfrutar de la lur solar la y hemas pees to la. mombilla calida en la mesita de methe 


\section{Anexo 6.1. Adaptación al español del instrumento de evaluación de las actitudes del alumnado hacia la ciencia BRAINS}

En las siguientes preguntas no hay respuestas "correctas" o "incorrectas". Simplemente nos interesan sus sentimientos sobre una serie de cuestiones relacionadas con las ciencias y su aprendizaje.

- Indique en qué medida está de acuerdo o en desacuerdo con cada una de las siguientes afirmaciones.

- Coloree con boligrafo azul el círculo de h opción que mejor represente su respuesta.

- Marque solo una respuesta para cada pregunta.

- Tenga en cuenta que si no sabe contestar a algo lo puede dejar en blanco.
$\square$ Niño $\square$ Niña
Edad:
Curso:

\begin{tabular}{|c|c|c|c|c|c|}
\hline & 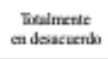 & 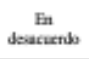 & $\begin{array}{l}\text { No enary } \\
\text { segaro }\end{array}$ & De axusto & $\begin{array}{l}\text { Tredmette } \\
\text { a axuesto }\end{array}$ \\
\hline Disfruto de las ciencias & $\mathrm{O}$ & $\mathrm{O}$ & $\mathrm{O}$ & $\mathrm{O}$ & $\mathrm{O}$ \\
\hline Los cientificos son muy respetados & $\mathrm{O}$ & $\mathrm{O}$ & $\mathrm{O}$ & $\mathrm{O}$ & $\mathrm{O}$ \\
\hline $\begin{array}{l}\text { La mayoria de las personas deberia entender las ciencias porque } \\
\text { afectan a sus vidas }\end{array}$ & $\mathrm{O}$ & $\mathrm{O}$ & $\mathrm{O}$ & $\mathrm{O}$ & $\mathrm{O}$ \\
\hline Si voy a la universidad estudiaré una carrera relacionada con ciencias & $\mathrm{O}$ & $\mathrm{O}$ & $\mathrm{O}$ & $\mathrm{O}$ & $\mathrm{O}$ \\
\hline Estoy seguro de que puedo hacer bien los exámenes de ciencias & $\mathrm{O}$ & $\mathrm{O}$ & $\mathrm{O}$ & $\mathrm{O}$ & $\mathrm{O}$ \\
\hline Suelo rendirme cuando no entiendo un concepto de ciencias & $\mathrm{O}$ & $\mathrm{O}$ & $\mathrm{O}$ & $\mathrm{O}$ & $\mathrm{O}$ \\
\hline Ciencias es una de las asignaturas escolares mís interesantes & $\mathrm{O}$ & $\mathrm{O}$ & $\mathrm{O}$ & $\mathrm{O}$ & $\mathrm{O}$ \\
\hline $\begin{array}{l}\text { Los maestros me animan a entender bs conceptos en las clases de } \\
\text { ciencias }\end{array}$ & $\mathrm{O}$ & $\mathrm{O}$ & $\mathrm{O}$ & $\mathrm{O}$ & $\mathrm{O}$ \\
\hline Mis familiares trabajan en carreras cientificas & $\mathrm{O}$ & $\mathrm{O}$ & $\mathrm{O}$ & $\mathrm{O}$ & $\mathrm{O}$ \\
\hline Mis familiares trabajan en carreras de ingenieria & $\mathrm{O}$ & $\mathrm{O}$ & $\mathrm{O}$ & $\mathrm{O}$ & $\mathrm{O}$ \\
\hline Las ciencias son fáciles para mi & $\mathrm{O}$ & $\mathrm{O}$ & $\mathrm{O}$ & $\mathrm{O}$ & $\mathrm{O}$ \\
\hline No voy a estudiar una carrera relacionada con ciencias en el futuro & $\mathrm{O}$ & $\mathrm{O}$ & $\mathrm{O}$ & $\mathrm{O}$ & $\mathrm{O}$ \\
\hline No voy a estudiar una carrera relacionada con ingenieria en el futuro & $\mathrm{O}$ & $\mathrm{O}$ & $\mathrm{O}$ & $\mathrm{O}$ & $\mathrm{O}$ \\
\hline No puedo entender las ciencias aunque me esfuerce mucho & $\mathrm{O}$ & $\mathrm{O}$ & $\mathrm{O}$ & $\mathrm{O}$ & $\mathrm{O}$ \\
\hline Llegaré a ser un cientifico en el futuro & $\mathrm{O}$ & $\mathrm{O}$ & $\mathrm{O}$ & $\mathrm{O}$ & $\mathrm{O}$ \\
\hline Llegaré a ser un ingeniero en el futuro & $\mathrm{O}$ & $\mathrm{O}$ & $\mathrm{O}$ & $\mathrm{O}$ & $\mathrm{O}$ \\
\hline Puedo entender conceptos dificiles de ciencias & $\mathrm{O}$ & $\mathrm{O}$ & $\mathrm{O}$ & $\mathrm{O}$ & $\mathrm{O}$ \\
\hline Realmente disfruto las clases de ciencias & $\mathrm{O}$ & $\mathrm{O}$ & $\mathrm{O}$ & $\mathrm{O}$ & $\mathrm{O}$ \\
\hline Continuaré estudiando ciencias auando termine el colegio & $\mathrm{O}$ & $\mathrm{O}$ & $\mathrm{O}$ & $\mathrm{O}$ & $\mathrm{O}$ \\
\hline Mi familia me anima a interesarme por las ciencias & $\mathrm{O}$ & $\mathrm{O}$ & $\mathrm{O}$ & $\mathrm{O}$ & 0 \\
\hline Estoy seguro de que puedo entender las ciencias & $\mathrm{O}$ & $\mathrm{O}$ & $\mathrm{O}$ & $\mathrm{O}$ & $\mathrm{O}$ \\
\hline
\end{tabular}




\begin{tabular}{|c|c|c|c|c|c|}
\hline & $\begin{array}{l}\text { Tiedmette } \\
\text { an dosactertb }\end{array}$ & $\begin{array}{c}\text { Fin } \\
\text { desacteribs }\end{array}$ & $\begin{array}{c}\text { No cuary } \\
\text { segaro }\end{array}$ & De ianuto & $\begin{array}{l}\text { Tixulmettr } \\
\text { a avuesdo }\end{array}$ \\
\hline Vivimos en un mundo mejor debido a las ciencias & $\mathrm{O}$ & $\mathrm{O}$ & $\mathrm{O}$ & $\mathrm{O}$ & $\mathrm{O}$ \\
\hline Disfrutaria trabajando en una carrera relacionada con las ciencias & $\mathrm{O}$ & $\mathrm{O}$ & $\mathrm{O}$ & $\mathrm{O}$ & $\mathrm{O}$ \\
\hline Disfrutaria trabajando en una carrera relacionada con la ingenieria & $\mathrm{O}$ & $\mathrm{O}$ & $\mathrm{O}$ & $\mathrm{O}$ & $\mathrm{O}$ \\
\hline $\begin{array}{l}\text { Conocer las ciencias puede ayudarme a tomar mejores decisiones } \\
\text { sobre mi salud }\end{array}$ & $\mathrm{O}$ & $\mathrm{O}$ & $\mathrm{O}$ & $\mathrm{O}$ & $\mathrm{O}$ \\
\hline Mi familia me anima a seguir una carrera relacionada con las ciencias & $\mathrm{O}$ & $\mathrm{O}$ & $\mathrm{O}$ & $\mathrm{O}$ & $\mathrm{O}$ \\
\hline Me gustaria hacer experimentos cientificos an casa & $\mathrm{O}$ & $\mathrm{O}$ & $\mathrm{O}$ & $\mathrm{O}$ & $\mathrm{O}$ \\
\hline Realmente me gustan las ciencias & $\mathrm{O}$ & $\mathrm{O}$ & $\mathrm{O}$ & $\mathrm{O}$ & $\mathrm{O}$ \\
\hline $\begin{array}{l}\text { A los cientificos generalmente les gusta ir a trabajar incluso cuando } \\
\text { tienen un dia libre }\end{array}$ & $\mathrm{O}$ & $\mathrm{O}$ & $\mathrm{O}$ & $\mathrm{O}$ & $\Omega$ \\
\hline $\begin{array}{l}\text { El conocimiento de las ciencias me ayuda a proteger el medio } \\
\text { ambiente }\end{array}$ & $\mathrm{O}$ & $\mathrm{O}$ & $\mathrm{O}$ & $\mathrm{O}$ & $\mathrm{O}$ \\
\hline Las ciencias me ayudarín a comprender el mundo que me rodea & $\mathrm{O}$ & $\mathrm{O}$ & $\mathrm{O}$ & $\mathrm{O}$ & $\mathrm{O}$ \\
\hline Estudiaré más asignaturas de ciencias en el futuro & $\mathrm{O}$ & $\mathrm{O}$ & $\mathrm{O}$ & $\mathrm{O}$ & $\mathrm{O}$ \\
\hline $\begin{array}{l}\text { Las personas con carreras relacionadas con las ciencias tienen una } \\
\text { vida familiar normal }\end{array}$ & $\mathrm{O}$ & $\mathrm{O}$ & $\mathrm{O}$ & $\mathrm{O}$ & $\mathrm{O}$ \\
\hline $\begin{array}{l}\text { Las personas con carreras relacionadas con la ingenieria tienen una } \\
\text { vida familiar normal }\end{array}$ & $\mathrm{O}$ & $\mathrm{O}$ & $\mathrm{O}$ & $\mathrm{O}$ & $\mathrm{O}$ \\
\hline No me gustan las ciencias & $\mathrm{O}$ & $\mathrm{O}$ & $\mathrm{O}$ & $\mathrm{O}$ & $\mathrm{O}$ \\
\hline
\end{tabular}




\section{Anexo 6.2. Rúbrica de evaluación y escala de observación}

Nombre:

Rúbrica de evaluación de las actividades de la UD:

\begin{tabular}{|c|c|c|c|}
\hline & M & $\mathrm{R}$ & B \\
\hline 1. Experimentos con electricidad estática y su reflexión. & & & \\
\hline 2. Ficha de experimentos con corriente eléctrica. & & & \\
\hline 3. Búsqueda de información en internet. & & & \\
\hline 4. Resumen electricidad estática y corriente eléctrica. & & & \\
\hline 5. Ficha de los tipos de bombillas. & & & \\
\hline 6. Gráficos de barras sobre consumo, precio y horas. & & & \\
\hline 7. Definición y explicación de la bombilla más rentable. & & & \\
\hline 8. Gráfico de líneas a través del problema. & & & \\
\hline $\begin{array}{l}\text { 9. Recuento de bombillas, gráficos de sectores individual y } \\
\text { grupal y reflexión sobre qué conviene hacer en mi casa y } \\
\text { clase. }\end{array}$ & & & \\
\hline $\begin{array}{l}\text { 10. Ficha de experimentos con magnetismo y } \\
\text { electromagnetismo. }\end{array}$ & & & \\
\hline 11. Resumen magnetismo y electromagnetismo. & & & \\
\hline 12. Ficha de experimentos con el color. & & & \\
\hline 13. Dibujo con colores cálidos y fríos. & & & \\
\hline 14. Proceso de ingeniería y dibujo de la habitación. & & & \\
\hline 15. Exposición de la presentación (oral y diapositivas). & & & \\
\hline 16. Valoración global del cuaderno de campo. & & & \\
\hline 17. Prueba escrita (valorar cada actividad). & & tich & \\
\hline
\end{tabular}

\section{Escala de observación de los EAEG:}

\begin{tabular}{|l|l|l|l|}
\cline { 2 - 4 } \multicolumn{1}{l|}{$\begin{array}{l}\text { Manifiesta autonomía en la planificación y ejecución de } \\
\text { acciones y tareas y tiene iniciativa en la toma de decisiones. }\end{array}$} & & & \\
\hline $\begin{array}{l}\text { Conoce y respeta las normas de uso y de seguridad de los } \\
\text { instrumentos y de los materiales de trabajo. }\end{array}$ & & & \\
\hline $\begin{array}{l}\text { Utiliza estrategias para realizar trabajos de forma individual } \\
\text { y en equipo. }\end{array}$ & & & \\
\hline
\end{tabular}


Anexo 6.3. Ejemplo de la actividad 9 evaluada por un mismo maestro a tres alumnos con las tres calificaciones diferentes

\section{BIEN}
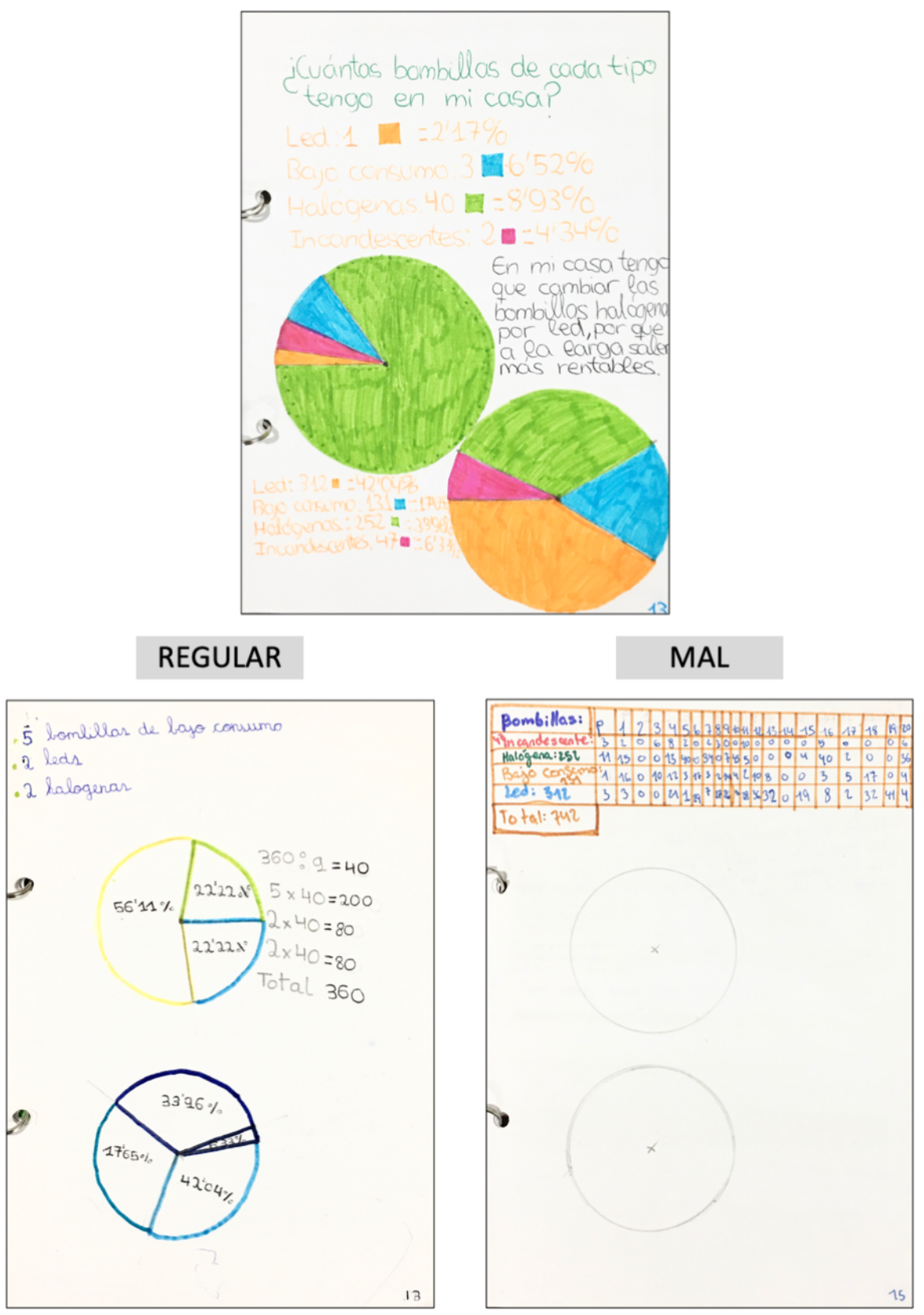


\section{Anexo 6.4. Información sobre la estructura, instrucciones para la utilización del instrumento de evaluación del desarrollo competencial escolar y un ejemplo concreto de evaluación}

\section{Estructura del instrumento:}

El instrumento de evaluación del desarrollo competencial escolar se constituye por un conjunto de filas y columnas que forman un entramado de celdas. Su apariencia es variable dependiendo del número de áreas sobre las que se trabaje en una UD, el número de actividades que la compongan y el conjunto de EAE a evaluar dependiendo de los contenidos abordados.

Siguiendo el ejemplo mostrado en la Figura 1, en la primera columna del lado izquierdo se sitúa el área en la que se ha programado la UD. En este caso Ciencias de la Naturaleza en color verde, Matemáticas en rojo y Educación Plástica en naranja. En la segunda columna se muestra tanto el título de los bloques de contenidos como el conjunto de EAE correspondientes a los contenidos abordados en cada área. Las columnas siguientes poseen una indicación numérica en la parte superior y representan a cada una de las actividades en las que se divide el desarrollo de la UD. A continuación, se muestra una columna con la indicación $G$, que representa a los EAE globales (EAEG) calificados en la UD. Una «X» indica que una actividad contribuye al desarrollo del EAE de la fila donde se encuentra. Aclarar que los números que se encuentran en la columna con la numeración 17 pertenecen a cada ejercicio evaluado en la prueba escrita y contribuyen al desarrollo del EAE de la fila donde se encuentran -el ejercicio 1 no aparece al no contribuir al desarrollo de ningún EAE- La columna gris con la indicación T ha de contener la suma total de las puntuaciones de cada EAE. Las últimas siete columnas poseen como indicación las siglas correspondientes a la competencia clave que representan. Las «X $»$ aquí indican que el EAE de la fila donde se encuentra contribuye al desarrollo de una determinada competencia.

Por otra parte, los denominadores que se encuentran en la parte inferior de cada una de las siete columnas finales representan el máximo puntaje posible a alcanzar en cada competencia. El hueco del numerador de la fracción ha de contener la puntuación alcanzada por el alumno en cada competencia.

Por último, el denominador que se encuentra en una de las casillas de la derecha del instrumento representa el máximo de puntuación posible a 
alcanzar en la totalidad de las competencias, siendo la suma del resto de denominadores. El hueco del numerador de la fracción ha de contener la puntuación alcanzada por el alumno en la totalidad de las competencias, siendo la suma del resto de numeradores. La última ha de contener el porcentaje de nivel competencial derivado de cada fracción. En la Figura 1 se muestra el aspecto de la estructura del instrumento creado para esta UD aún sin haberse realizado una evaluación. 


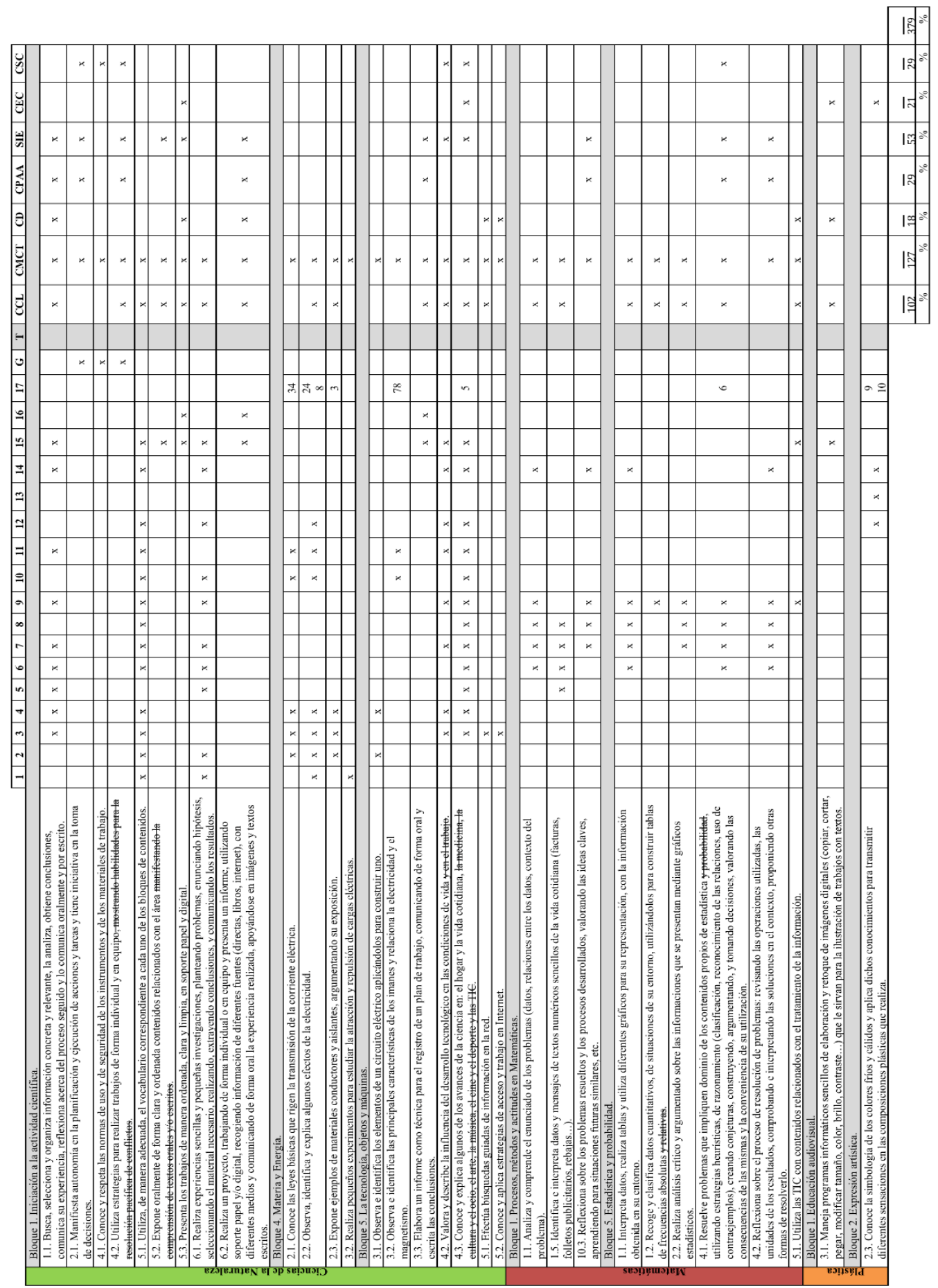

Figura 1. Aspecto de la estructura del instrumento sin haberse realizado una evaluación. 
2. Instrucciones para el desarrollo del análisis:

El desarrollo del análisis constó de cinco fases:

- Fase 1: se calificaron las actividades de la UD a través de la rúbrica (Anexo 6.2). De la misma manera, también se calificaron los EAEG a través de la escala de observación (Anexo 6.2).

- Fase 2: se integraron todas las calificaciones de las actividades en el instrumento de evaluación del desarrollo competencial escolar: para ello, se rodearon las « $\mathrm{x}\rangle$ presentes en las columnas numeradas cuando en su correspondiente actividad se obtuvo la calificación $\mathrm{B}$, se tacharon con una línea cuando se obtuvo $\mathrm{R}$ y no se hizo nada cuando se obtuvo M. A continuación, se realizó la misma operación con las « «x» presentes en la columna $G$ según las calificaciones de cada EAEG. Con los números que se encuentran en la columna 17 se realizó este mismo proceso según las calificaciones obtenidas en cada ejercicio de la prueba escrita.

- Fase 3: se sumó la puntuación total obtenida en cada EAE en la columna T: para ello, se realizó una suma horizontal recogiendo las puntuaciones otorgadas por cada actividad y por los EAEG a cada EAE, contándose 1 punto cuando había un círculo, 0,5 cuando se trataba de una línea y 0 cuando no existía ninguna marca.

- Fase 4: se sumó la puntuación total obtenida en cada competencia en el hueco destinado a cada numerador: para ello, se realizó una suma vertical en cada una de las siete últimas columnas recogiendo las puntuaciones de la columna $\mathrm{T}$ solo cuando existía una «X $\mathrm{X}$ en su correspondiente fila. Una vez obtenidos estos datos, se sumaron todos los numeradores y se anotó el resultado en el hueco destinado al numerador total.

- Fase 5: se calculó el porcentaje de nivel competencial derivado de cada una de las fracciones y se anotó en su respectiva fila. Este porcentaje es el que sirvió para determinar el grado de adquisición competencial.

3. Un ejemplo concreto de evaluación:

A continuación, se muestra un ejemplo de la evaluación de un alumno. En la Figura 2 se muestra la rúbrica de evaluación de las actividades de la UD habiéndose realizado la evaluación. 
$1 F 18$

Nombre:

\section{Actividades de la Unidad Didáctica:}

\begin{tabular}{|c|c|c|c|}
\hline & M & $\mathrm{R}$ & $\mathrm{B}$ \\
\hline 1. Experimentos con electricidad estática y su reflexión. & & & $x$ \\
\hline 2. Ficha de experimentos con corriente eléctrica. & & & X \\
\hline 3. Búsqueda de información en internet. & & & $x$ \\
\hline 4. Resumen electricidad estática y corriente eléctrica. & & $x$ & \\
\hline 5. Ficha de los tipos de bombillas. & & & X \\
\hline 6. Gráficos de barras sobre consumo, precio y horas. & & & $x$ \\
\hline 7. Definición y explicación de la bombilla más rentable. & & & $x$ \\
\hline 8. Gráfico de líneas a través del problema. & & $x$ & \\
\hline $\begin{array}{l}\text { 9. Recuento de bombillas, gráficos de sectores individual y } \\
\text { grupal y reflexión sobre qué conviene hacer en mi casa. }\end{array}$ & & $x$ & \\
\hline $\begin{array}{l}\text { 10. Ficha de experimentos con magnetismo y } \\
\text { electromagnetismo. }\end{array}$ & & & $x$ \\
\hline 11. Resumen magnetismo y electromagnetismo. & & $x$ & \\
\hline 12. Ficha de experimentos con el color. & & x & \\
\hline 13. Dibujo con colores cálidos y fríos. & & $x$ & \\
\hline 14. Proceso de ingeniería y dibujo de la habitación. & & & $x$ \\
\hline 15. Exposición de la presentación (oral y diapositivas). & $x$ & & \\
\hline 16. Valoración global del cuaderno de campo. & & & $x$ \\
\hline 17. Prueba escrita (valorar cada actividad). & & & \\
\hline
\end{tabular}

\section{Estándares de Aprendizaje Evaluables globales:}

Manifiesta autonomía en la planificación y ejecución de acciones y tareas y tiene iniciativa en la toma de decisiones. Conoce y respeta las normas de uso y de seguridad de los instrumentos y de los materiales de trabajo.

Utiliza estrategias para realizar trabajos de forma individual y en equipo.

Figura 2. Estructura de la rúbrica de evaluación de las actividades de la UD habiéndose realizado una evaluación

En la Figura 3 se muestra el aspecto de la estructura del instrumento habiéndose integrado las calificaciones de las actividades anteriores. 


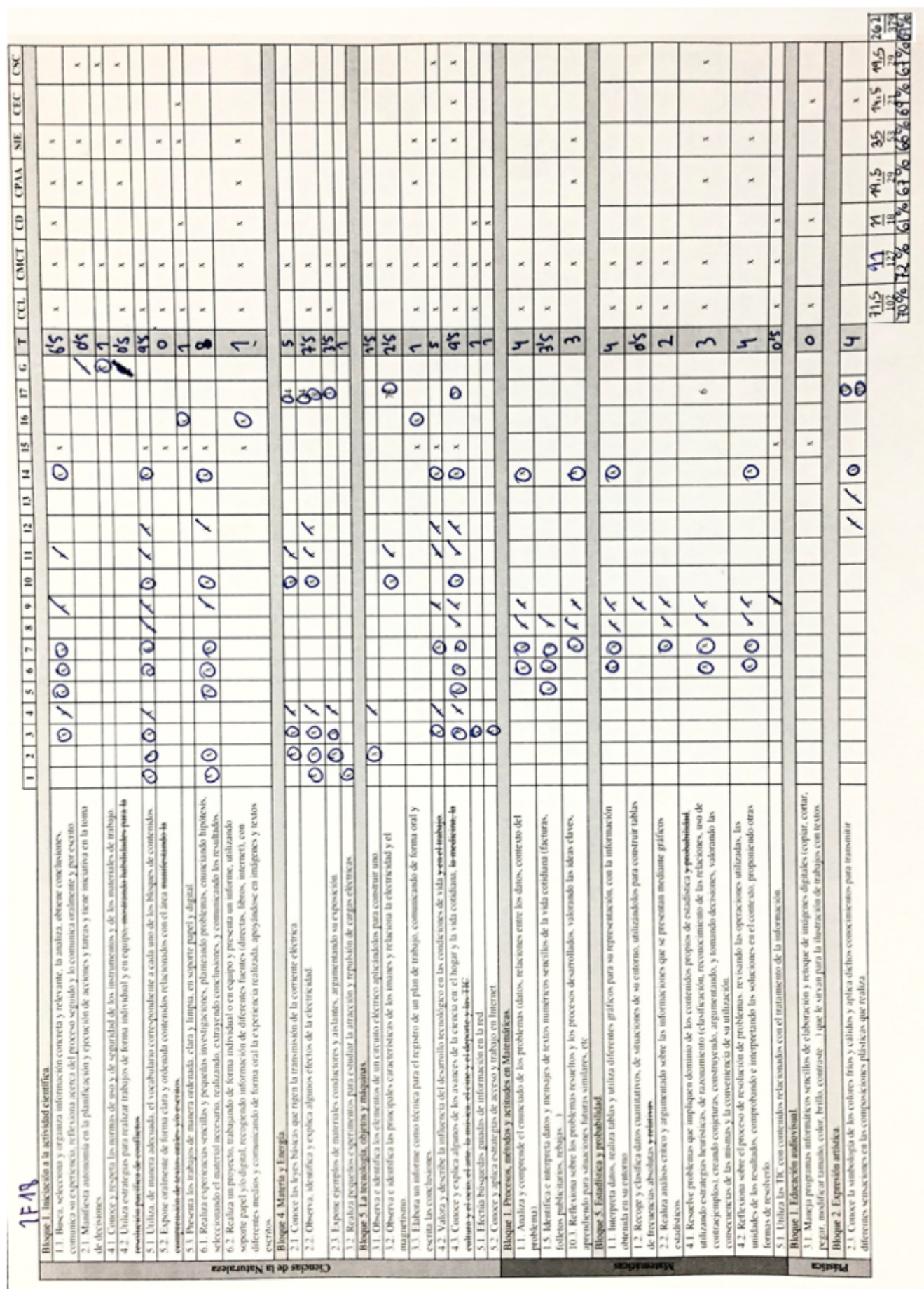

Figura 3. Aspecto de la estructura del instrumento tras integrar las calificaciones de la evaluación. 
A la luz de este ejemplo el alumno obtuvo un $70 \%$ de desarrollo competencial escolar en la CCL, un $72 \%$ en CMCT, un $61 \%$ en CD, un $67 \%$ en CPAA, un $66 \%$ en SIE, un $69 \%$ en CEC, un $67 \%$ en CSC y un $69 \%$ en su CG. Conviene recordar que, si bien este instrumento pudo servir de ayuda en la evaluación del desarrollo competencial escolar del alumnado, la competencia se trata de un constructo complejo (Ortiz-Revilla, Greca y Adúriz-Bravo, 2018d; Zabala y Arnau, 2007) cuyo desarrollo requiere del diseño de tareas o situaciones de aprendizaje cercanas a la realidad (Miralles Martínez et al., 2012) que posibiliten resolver problemas, aplicar conocimientos y promover una amplia gama de destrezas en los estudiantes (Bolívar, 2008; Guarro Pallás, 2008). Sin esta premisa cualquier propuesta de evaluación carece de sentido. 


\section{Anexo 6.5. Panel de expertos encargados de la validación del instrumento de evaluación del desarrollo competencial escolar}

\begin{tabular}{|c|c|}
\hline CCL & $\begin{array}{l}\text { Jaime Ibáñez Quintana: Profesor Contratado Doctor de Didáctica } \\
\text { de la Lengua y la Literatura Española en el Departamento de } \\
\text { Didácticas Específicas de la Facultad de Educación de la } \\
\text { Universidad de Burgos. }\end{array}$ \\
\hline CMCT & $\begin{array}{l}\text { Miguel Ángel Queiruga Dios: Profesor Ayudante Doctor de } \\
\text { Didáctica de las Ciencias Experimentales en el Departamento de } \\
\text { Didácticas Específicas de la Facultad de Educación de la } \\
\text { Universidad de Burgos. Profesor del Área de Ciencias de } \\
\text { Educación Secundaria Obligatoria en el Colegio Jesús-María } \\
\text { (Burgos). }\end{array}$ \\
\hline $\mathrm{CD}$ & $\begin{array}{l}\text { Víctor Abella García: Profesor Contratado Doctor de Didáctica y } \\
\text { Organización Escolar en el Departamento de Ciencias de la } \\
\text { Educación de la Facultad de Educación de la Universidad de } \\
\text { Burgos. Director del Centro de Enseñanza Virtual de la } \\
\text { Universidad de Burgos (UBUCEV). }\end{array}$ \\
\hline CPAA & $\begin{array}{l}\text { María Consuelo Sáiz Manzanares: Profesora Titular de Universidad } \\
\text { de Psicología Evolutiva y de la Educación en el Departamento de } \\
\text { Ciencias de la Salud de la Facultad de Ciencias de la Salud de la } \\
\text { Universidad de Burgos. }\end{array}$ \\
\hline SIE & $\begin{array}{l}\text { Francisco Javier Villar Mata: Profesor Titular de Universidad de } \\
\text { Economía Aplicada en el Departamento de Economía Aplicada de } \\
\text { la Facultad de Educación de la Universidad de Burgos. }\end{array}$ \\
\hline CEC & $\begin{array}{l}\text { María Pilar Alonso Abad: Profesor Contratado Doctor de Historia } \\
\text { del Arte en el Departamento de Historia, Geografía y } \\
\text { Comunicación de la Facultad de Humanidades y Comunicación de } \\
\text { la Universidad de Burgos. }\end{array}$ \\
\hline$\overline{\mathrm{CSC}}$ & $\begin{array}{l}\text { Delfín Ortega Sánchez: Profesor Titular de Universidad de } \\
\text { Didáctica de las Ciencias Sociales en el Departamento de } \\
\text { Didácticas Específicas de la Facultad de Educación de la } \\
\text { Universidad de Burgos. }\end{array}$ \\
\hline
\end{tabular}


Anexo 6.6. Segunda variante del instrumento de evaluación del desarrollo competencial escolar

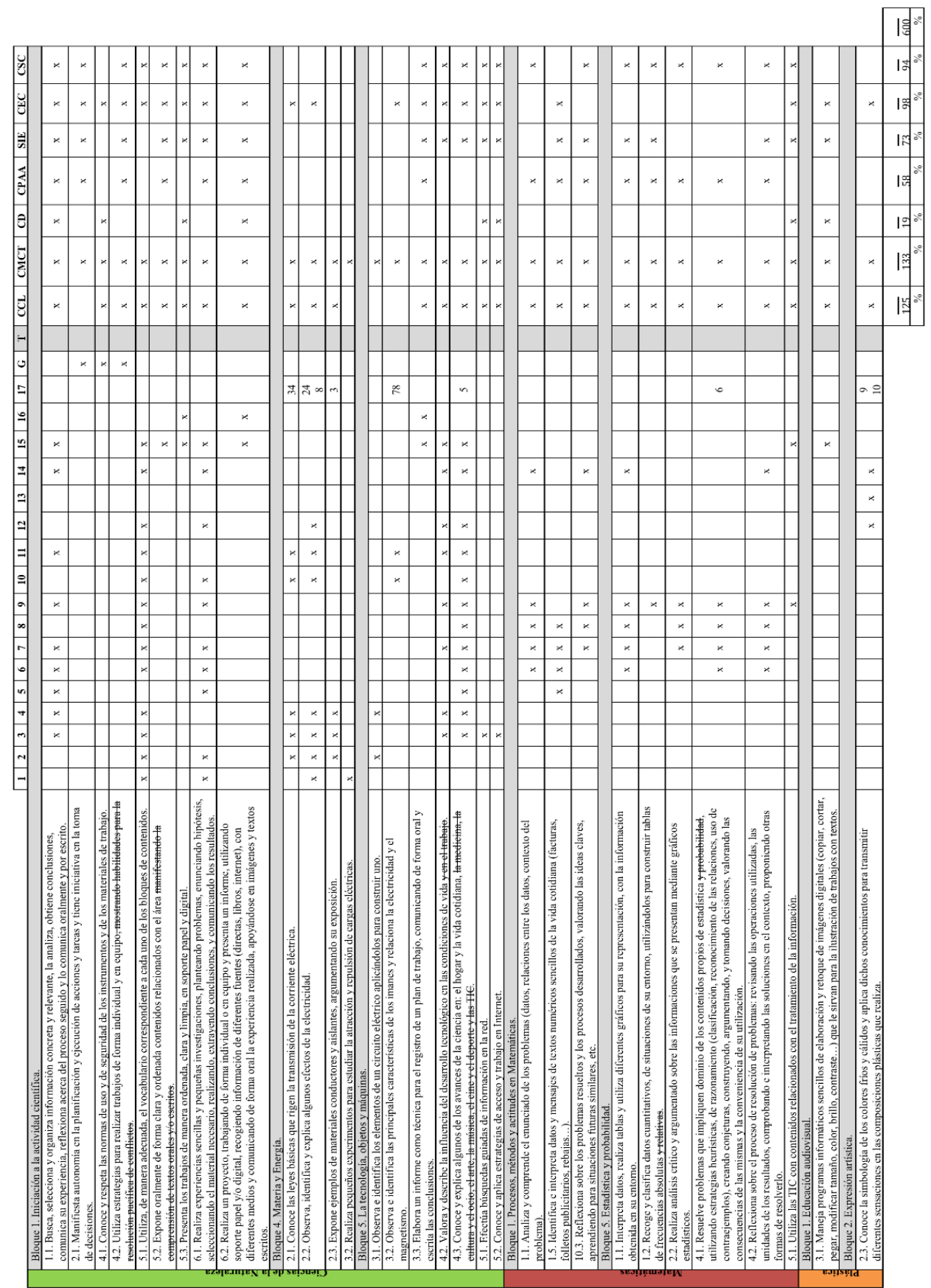




\section{Anexo 6.7. Comparación de los resultados del Grupo 4 obtenidos con las dos variantes del instrumento de evaluación competencial escolar}

Como se ha comentado, los resultados obtenidos con las dos variantes del instrumento de evaluación competencial escolar — la realizada por el investigador y los maestros y la propuesta por los expertos- del Grupo 4 se compararon con el fin de analizar si existían diferencias significativas al aplicar una y otra variante del instrumento y así comprobar y validar su fiabilidad.

Así, se procedieron a tratar mediante estadística inferencial los datos numéricos deducidos de un análisis cualitativo idéntico a los realizados, recurriéndose a la versión 26.0 de software estadístico IBM SPSS Statistics. Dado el tamaño de la muestra, para evaluar la normalidad de la distribución de los datos se empleó la prueba de Shapiro-Wilk, la cual arrojó resultados de un $\mathrm{p}$-valor $<.05$ significativo en las 16 variables competenciales — se asignó un 1 después de la sigla de cada competencia cuando la variable correspondía al resultado obtenido con la primera variante del instrumento y un 2 con la segunda-, lo que indicó una violación de la suposición de normalidad. Los resultados de esta prueba se muestran en la Tabla 1.

Tabla 1. Prueba de Shapiro-Wilk para las competencias evaluadas con la primera y la segunda variante del instrumento

\begin{tabular}{lrrrr}
\hline \hline & \multicolumn{3}{c}{ Shapiro-Wilk } & \\
\cline { 2 - 5 } & Estadístico & & gl & Sig. \\
\hline CG &, 847 & 20 &, 005 \\
CCL &, 815 & 20 &, 001 \\
CMCT &, 859 & 20 &, 008 \\
CD &, 885 & 20 &, 022 \\
CPAA &, 804 & 20 &, 001 \\
SIE &, 850 & 20 &, 005 \\
CEC &, 839 & 20 &, 004 \\
CSC &, 846 & 20 &, 005 \\
CG2 &, 807 & 20 &, 001 \\
CCL2 &, 846 & 20 &, 005 \\
CMCT2 &, 845 & 20 &, 004
\end{tabular}




\begin{tabular}{llll} 
CD2 &, 881 & 20 &, 019 \\
CPAA2 &, 737 & 20 &, 000 \\
SIE2 &, 803 & 20 &, 001 \\
CEC2 &, 882 & 20 &, 019 \\
CSC2 &, 800 & 20 &, 001 \\
\hline \hline
\end{tabular}

a. Grupo = Grupo 4

Por lo tanto, se emplearon estadísticos no paramétricos para el análisis de datos. Concretamente se utilizó el coeficiente de correlación Rho de Spearman. Esta prueba reveló la existencia de una correlación significativa muy fuerte entre resultado obtenido con la primera y la segunda variante del instrumento en todas las competencias, lo que demostró la fiabilidad del instrumento de evaluación del desarrollo competencial escolar con independencia del evaluador. En la Tabla 2 se muestran los resultados de esta prueba. 
Tabla 2. Coeficiente de correlación Rho de Spearman para la competencias evaluadas con la primera y la segunda variante del instrumento

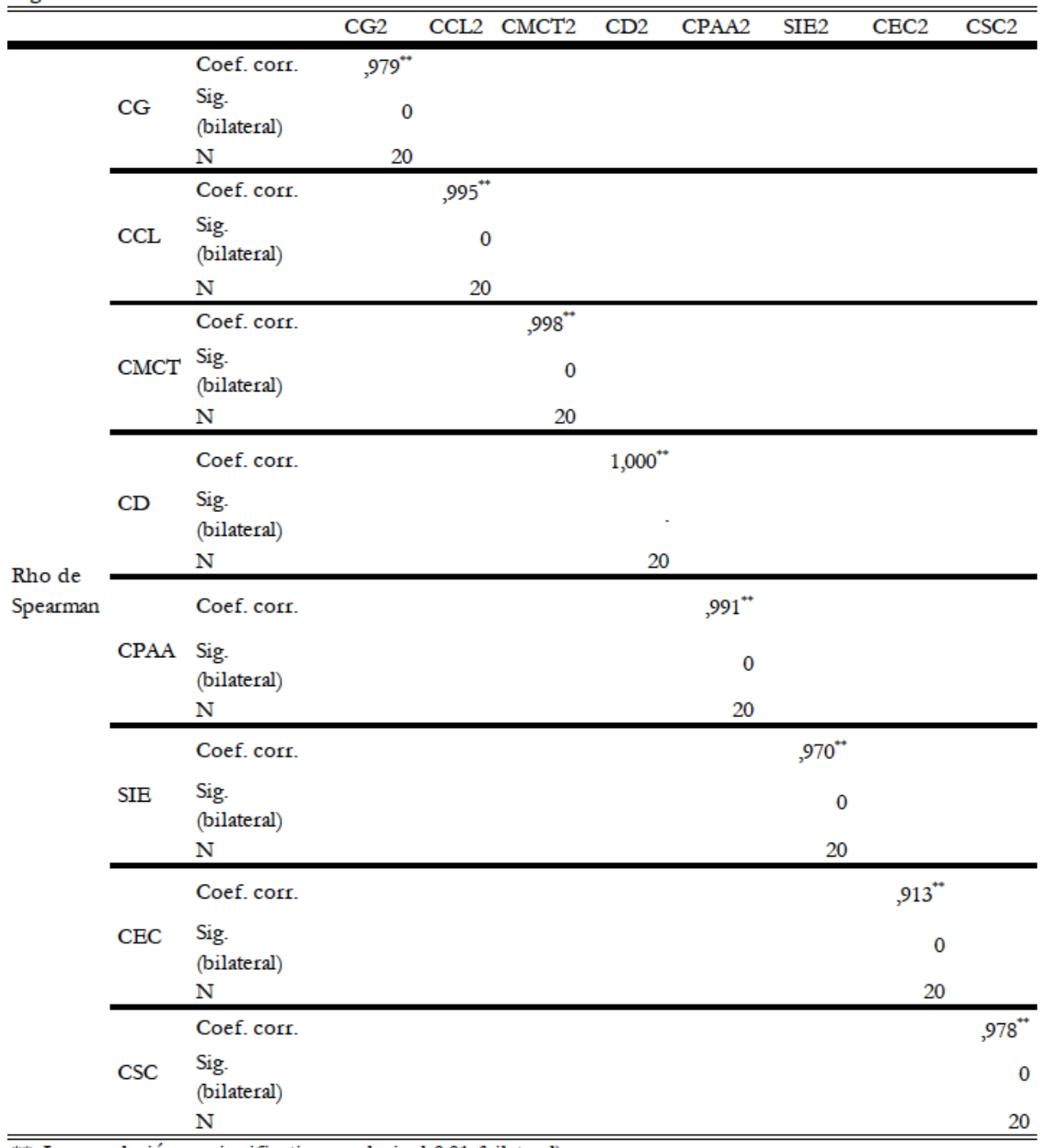

**. La correlación es significativa en el nivel 0,01 (bilateral).

a. Grupo = Grupo 4 

